OFFICE OF CIVILIAN RADIOACTIVE WASTE MANAGEMENT

1. QA: QA

SPECIAL INSTRUCTION SHEET

Page: 1 of: 1

Complete Only Applicable Items

This is a placeholder page for records that cannot be scanned.

\begin{tabular}{l|l} 
2. Record Date & 3. Accession Number
\end{tabular}

$05 / 08 / 97$

MOL. 19971009.0699

4. Author Name(s)

ELAYER, RW

5. Author Organization

M\&O

6. Title/Description

DETERMINATION OF AVAILABLE VOLUME FOR REPOSITORY SITING

7. Document Number(s)

$\mathrm{BCA} 000000-01717-0200-(000007$

8. Version Designator

9. Document Type

10. Medium

DESIGN DOCUMENT

OPTIC; PAPER

11. Access Control Code

PUB

12. Traceability Designator

$\mathrm{BCA}(00000(0)-01717-0200-00007$

13. Comments

APPROVED ANALYSIS. ONE-OF-A-KIND

TO VIEW THIS DOCUMENT IN IT'S ORIGINAL FORM CONTACT THE RPC 


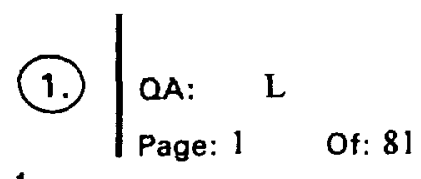

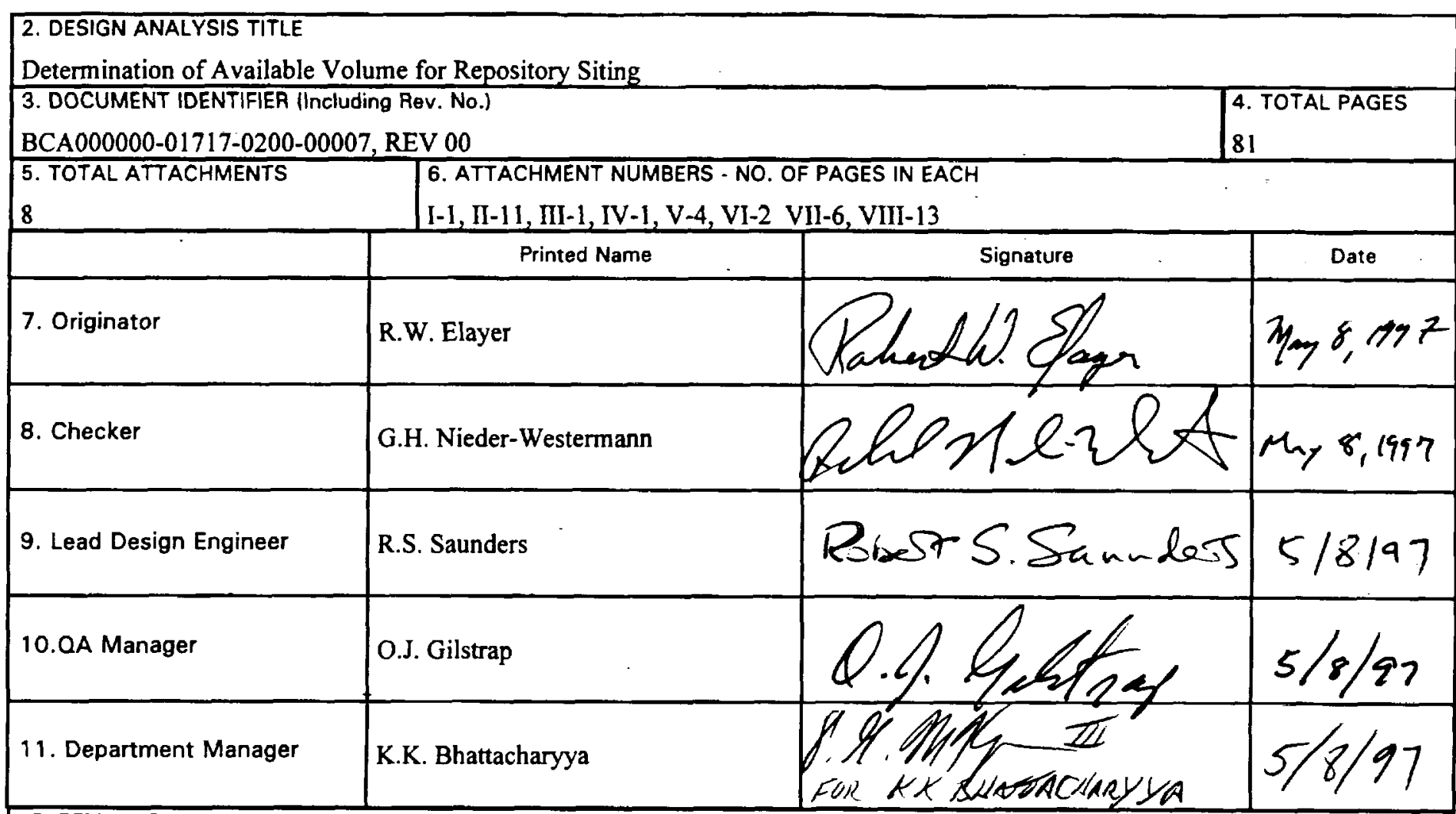


2. DESIGN ANALYSIS TITLE

Determination of Available Volume for Repository Siting

3. DOCUMENT IDENTIFIER (Including Rev. No.)

BCA000000-01717-0200-00007, REV 00

4. Revision No.

5. Description of Revision

Initial issue. 


\section{Determination of Available Volume for Repository Siting}

\section{TABLE OF CONTENTS}

1. PURPOSE

2. QUALITY ASSURANCE 5

3. METHOD 5

4. DESIGN INPUTS 6

4.1 DESIGN PARAMETERS 6

4.1.1 Topography 6

4.1.2 Borehole Data 6

4.1.3 Outcrop Data 7

4.1.4 ESF Mapping Data 7

4.1.5 Faults

4.1.6 Groundwater Table $\quad 8$

4.1.7 ESF Layout $\quad 8$

4.2 CRITERIA 9

4.2.1 Minimum Repository Overburden 9

4.3 ASSUMPTIONS 9

4.3.1 Topography 9

4.3.2 Repository Host Horizon (RHH) 9

4.3.3 Repository Siting Area 9

4.3.4 Repository Standoff Below Top of RHH 9

4.3.5 Repository Standoff Above Bottom of RHH 10

4.3.6 Groundwater Standoff 10

4.3.7 Subsurface Fault Standoff $\quad 10$

4.3.8 Type I Faults 10

4.3.9 Subsurface Fault Projection 11

4.4 CODES AND STANDARDS 11

4.4.1 CFR, Title 10, Part 960 11

5. REFERENCES 11

6. USE OF COMPUTER SOFTWARE 16

6.1 QUALIFIED SOFTWARE 16

6.2 NON-QUALIFIED SOFTWARE 16 
Title: Determination of Available Volume for Repository Siting

7. DESIGN ANALYSIS 16

7.1 COMPUTER GEOLOGY MODELING 16

7.1.1 Previous Computer Geology Models 17

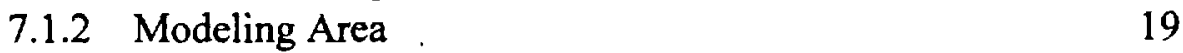

7.1.3 Topography Modeling 21

7.1.4 Overburden Modeling 21

7.1.5 Stratigraphy Modeling 23

7.1.6 Fault Modeling 25

7.1.7 Groundwater Modeling 26

7.1.8 ESF Modeling 26

7.1.9 Reference Repository Analysis Plane Modeling 26

7.1.10 Design Model Disposition 28

7.2 STRATIGRAPHY 28

$\begin{array}{ll}7.2 .1 & \text { Lithostratigraphy } \\ 7 & 29\end{array}$

7.2.2 Thermal/Mechanical Stratigraphy 33

7.3 REPOSITORY HOST HORIZON (RHH)

7.3.1 Previous Work 34

7.3.2 Definition of the RHH Top Contact 36

7.3.3 Description of TSw1 Unit above RHH 39

7.3.4 Description of RHH 43

7.3.5 Description of TSw3 Unit 50

7.4 STRUCTURES 50

7.4.1 North-Striking Faults $\quad 52$

7.4.2 Northwest-Striking Faults $\quad 54$

7.4.3 Fractures $\quad 54$

$\begin{array}{lll}7.4 .4 & \text { Strata Tilt } & 55\end{array}$

$\begin{array}{lll}7.5 & \text { REPOSITORY SITING } & 63\end{array}$

7.5.1 Previous Work 63

7.5.2 Overburden Considerations 63

7.5.3 Groundwater Considerations 64

7.5.4 Stratigraphic Considerations 64

$\begin{array}{lll}\text { 7.5.5 Fault Considerations } & 69\end{array}$

7.5.6 Repository Siting Volume 69

$\begin{array}{lll}\text { 8. CONCLUSIONS } & 76\end{array}$

9. ATTACHMENTS 80 


\section{PURPOSE}

The purpose of this analysis is to identify and define the volume of rock that would be available for siting the potential repository at Yucca Mountain. The objective of this analysis is to support development of the Viability Assessment (VA) repository layout design.

This analysis replaces the previous technical document on the same subject, which is entitled Definition of the Potential Repository Block (Reference 5.13). Definition of the siting volume is based on accepted criteria and assumptions that are detailed in this analysis, and does not address constructability, thermal and performance considerations, which are subjects for other analyses.

\section{QUALITY ASSURANCE}

This design analysis was prepared, reviewed and approved in accordance with QAP-3-9, Design Analysis. The subject of this analysis does not include any Permanent Engineering Items classified under QAP-2-3, Classification of Permanent Items, but does involve natural barriers, which are important to waste isolation. The natural barrier system is included in the Q-List as a result of an analysis presented as Appendix A in the Q-List (Reference 5.32).

This design activity was evaluated in accordance with QAP-2-0, Conduct of Activities, and was determined to be quality affecting and subject to the requirements of the QARD, Quality Assurance Requirements and Description. The rationale for classification was that the location of the repository may affect the natural barrier system. This analysis is subject to quality assurance controls in accordance with NLP-3-18, Documentation of QA Controls on Drawings, Specifications, Design Analyses, and Technical Documents.

Much of this design analysis is dependent upon data collected in the field through mapping, drilling, and testing. These data pertaining to Yucca Mountain subsurface geology have been collected over a wide span of years and under various QA programs. The collection and analysis of subsurface data is still continuing today. The resulting data, therefore, have a wide range of QA pedigrees from none to fully qualified. Because this analysis utilized both qualified and non-qualified data, it is considered to be preliminary and the outputs non-qualified. The conclusions from this analysis will not be used as input to documents supporting construction, fabrication, or procurement, and the formal tracking system controls described in NLP-3-15 (To Be Verified (TBV) and To Be Determined (TBD) Monitoring System) do not apply.

\section{METHOD}

This design analysis was developed by using analytical methods. Published documents, project documents, and data contained in the technical data base (TDB) were first reviewed for use in the analysis. The data were then organized and entered into the LYNX system database from which the computer geology model of the area was built. The model is identified as YMP.MO3Q and is 
referred to herein as the Design Model (see Section 7.1). The model was then analyzed to determine the available repository siting volume. Most of the illustrations contained in this design analysis were generated from the model and prepared for presentation using CoreIDRAW graphics software.

\section{DESIGN INPUTS}

\subsection{DESIGN PARAMETERS}

\subsubsection{Topography}

Topographic information used as input to this design analysis and included in the Technical Data Parameter Dictionary (Reference 5.3) consists of surface altitude (\#301). The data used in this design analysis were obtained from the TDB and were based on original 1:6,000-scale topographic maps (Assumption Section 4.3.1). The data were supplied in drawing interchange file ( $d x f$ ) format, with contours thinned to 20 -foot intervals. The $d x f$ input files are included in the YMP.MO3Q archive tape as hypso_200.dxf, hypso_201.dxf, hypso_202.dxf, and hypso_203.dxf in the directory YMP.MO3Q/misc (Attachment VII). The topographic surface and overburden surfaces were built using these input files as described in Section 7.1.3 of this analysis. The input source topographic maps are non-qualified, so the $d x f$ files which were derived from these maps are likewise nonqualified.

\subsubsection{Borehole Data}

Data from a total of 34 boreholes were used in this design analysis and included borehole collar location (Reference 5.3, \#597, borehole location), deviation survey (Reference 5.3, \#911 borehole attitude), borehole depth (Reference 5.3, \#924), stratigraphic unit location (Reference 5.3, \#1564) as derived from core and geophysical logs, and groundwater depth (Reference 5.3, \#359, watertable altitude). The data from each of these boreholes have varied qualification status depending mostly on when the data were collected. Data collected prior to 1989 , when the quality assurance program for the Yucca Mountain project was initiated, are generally classified as non-qualified, except in the case of geophysical log data that was later qualified by analysis of the collection procedures (Reference 5.61). Data collected after that date are all generally qualified, except for borehole SD-7, which is non-qualified at this time because the data included in the source document (Reference 5.45) used in this analysis were preliminary. The qualification status of the data for the 34 boreholes is identified in Attachment I. For this design analyis, the stratigraphic contact picks for a borehole are considered qualified if all the components (collar location, core log, bulk density log, and deviation survey) are all qualified. If any one of the components are non-qualified, the borehole picks are then likewise non-qualified.

Collar locations for the boreholes were taken from the Technical Data Base (TDB). The locations were reconfirmed during preparation of this design analysis document using a listing from the TDB dated February 6, 1997 (Reference 5.46). The collar locations used in the modeling are listed in Attachment II, along with the other data for the boreholes. The collar location data obtained from the TDB was in metric units, converted from English units using a $0.3048 \mathrm{~m} / \mathrm{ft}$ as the conversion factor. These data were rounded to two decimal places. 
In most cases, the lithostratigraphic contact picks used in the modeling came from the Yucca Mountain Project Stratigraphic Compendium (Reference 5.45). These contact picks were all based on core log interpretation. In some cases, however, contact picks were modified based on the interpretation of geophysical logs (References listed in Attachment I). This was only done where it was felt that the lithostratigraphic picks from the TDB did not agree or did not closely agree with the geophysical log interpretation. The contact picks used in the modeling are listed in Attachment II. All picks were according to the TDB except those identified in the comments column. Since the data were provided in English units rounded to the nearest foot, the depth picks were converted to metric, then rounded to two decimal places to be consistent with the collar data. The qualification category of the stratigraphic picks was determined by the qualification category of base data and is listed in Attachment I. The borehole data were added to the Design Model as database subset 7 (Attachment IV). These data are included in the archive tape (Reference 5.7) and are contained in the directory /YMP.MO3Q/dholes as the file $d h 7$ (Attachment VII).

\subsubsection{Outcrop Data}

Outcrop information along the west flank of Yucca Crest in Solitario Canyon was collected by the USGS in 1995 (Reference 5.47). The data consists of stratigraphic unit locations (Reference 5.3, \#1564) for three lithostratigraphic contacts. The locations were identified and surveyed for accurate control. The three contacts (see Section 7.2 for definitions) located include:

- base of the crystal-poor vitric nonwelded subzone of the Tiva Canyon Tuff

- base of the crystal-rich vitric moderately welded subzone of the Topopah Spring Tuff (top TSw1)

- $\quad$ base of the crystal-poor upper lithophysal zone of the Topopah Spring Tuff (top middle nonlithophysal zone, Tptpmn)

The first contact is above the stratigraphic section modeled in this design analysis, and so was not used in the modeling. The second contact is equivalent to the top of the TSwl unit in this design analysis. The third contact is included in this design analysis as the top of the middle nonlithophysal zone (Tptpmn), which is equivalent to the top of the TSw2 unit. These data are all considered to be qualified. These data were added to the Design Model as database subset 4 (Attachment IV). These data are included in the archive tape (Reference 5.7) and are contained in the directory /YMP.MO3Q/dholes as the file $d h 4$ (Attachment VII).

\subsubsection{ESF Mapping Data}

Stratigraphic contacts from the ESF underground development came from the North Ramp tunnel mapping summary report (Reference 5.44). This report covers the ESF tunnel from Stations $4+00$ to 28+00. At the time this design analysis was being prepared, the summary report for the ESF Main Drift was not available, but was released while the analysis was in its final stages (Reference 5.62). The data for the ESF Main Drift could therefore not be included in this design analysis, but will be reviewed at a later date to determine if any revisions to the model are necessary.

The data from the ESF mapping included stratigraphic unit locations (Reference 5.3,\#1564). To add this information to the LYNX system, the ESF data were treated as a borehole with its alignment coinciding with the right rib spring line of the tunnel. All contacts were referenced to this location 
Title: Determination of Available Volume for Repository Siting Document Identifier: BCA000000-01717-0200-00007, Rev. 00

Page: 8 of 81

in the tunnel. The trace of the right rib spring line was calculated from the tunnel alignment information presented in the ESF Layout Calculation (Reference 5.9). The coordinates for three contacts (at the right rib spring line) are listed in Attachment II. The three contacts identified in the model include:

- top TSwl unit

- top Repository Host Horizon (RHH)

- top middle nonlithophysal zone (Tptpmn)

Since this information came from qualified data, the contact coordinates are considered qualified. These data were added to the Design Model as database subset 8 (Attachment IV). These data are included in the archive tape (Reference 5.7) and are contained in the directory $/ Y M P . M O 3 Q /$ dholes as the file $d h 8$ (Attachment VII).

\subsubsection{Faults}

The fault data included in this design analysis consisted of fault location (Reference 5.3, \#8), fault attitude (Reference 5.3, \#7), fault type (Reference 5.3, \#10), and fault displacement (Reference 5.3, \#13). This information was taken from recent mapping by the USGS (Reference 5.48) and was obtained in a $d x f$ file which was converted to a LYNX map file and uploaded to the Design Model. The $d x f$ file is included in the archive tape of the Design Model as the file day faults.dxf in the directory YMP.MO3Q/misc (Attachment VII). These data are considered qualified. The LYNX fault map developed from this data is DAYf0996 (Attachments V and VII).

\subsubsection{Groundwater Table}

A contour map that represents the groundwater table (Reference 5.3, \#359, watertable altitude) was developed from data included in the RIB (Reference 5.4, Section 1.612). This document presents a contour map drawn on the potentiometric surface and is based on 1993 data from 28 boreholes, 14 of which are in the vicinity of the modeling area. These original data are qualified, but since the total model area was not described with contours, additional contours were added to the map to describe the remaining part of the area and the resulting data are non-qualified. In order to complete the groundwater table modeling in the far north, data for borehole G-2 had to be taken from the Yucca Mountain Project Stratigraphic Compendium (Reference 5.45). The data for this borehole are nonqualified. The groundwater contour map is in the LYNX file GWL_RIB and the data points are in $G W L \_R I B p$ (Attachments V and VII).

\subsubsection{ESF Layout}

An engineering model of the ESF was included in the illustrations in this design analysis for reference only. The controlling coordinate geometry was obtained from the ESF Layout Calculation (Reference 5.9). This reference was also used to define the layout for the right-rib spring line, which was used to input the ESF mapping data (Section 4.1.4). The ESF volume model is in M.ESF_R4 (Attachments VI and VII). 


\subsection{CRITERIA}

\subsubsection{Minimum Repository Overburden}

All subsurface portions of the repository within the perimeter drifts on the emplacement level shall be situated at least $200 \mathrm{~m}$ below the directly overlying ground surface [Reference 5.35, MGDSRD 3.7.2.2(F)]. This criteria was taken from the MGDSRD instead of the RDRD (Reference 5.34) since the requirements for the Geologic Setting. (Section 3.7.1 of the RDRD) are based on requirements in the MGDSRD that have been deleted. In addition, one requirement directly applicable to this analysis has been added to the MGDSRD that has not been reflected in the current version of the RDRD.

\subsection{ASSUMPTIONS}

\subsubsection{Topography}

The Topographical Survey Data and Surface Morphology shall be as described in Section 1.11 of the Reference Information Base (RIB) (Reference 5.4) [Reference 5.2, TDS 002]. This assumption is the basis for defining the 200-m minimum repository overburden criteria (Section 4.2.1, Repository). It is used in Sections 7.1.3, Topography Modeling, 7.1.4, Overburden Modeling, 7.5.2, Overburden Considérations, and 7.5.6, Repository Siting Volume.

\subsubsection{Repository Host Horizon (RHH)}

The Repository Host Horizon (RHH) is the geologic strata that is deemed to be suitable for repository siting (Section 7.3). The RHH will be located mainly in the TSw2 geologic unit. This assumption recognizes that recent evaluations have indicated the TSw1/TSw2 contact is not well defined and parts of the overlying TSwl unit may be suitable for repository placement [Reference 5.2, Key Assumption 022]. This assumption is used in Sections 7.1.5, Stratigraphy Modeling, 7.2, Stratigraphy, 7.3, Repository Host Horizon, 7.5.4, Stratigraphic Considerations, and 7.5.6, Repository Siting Volume.

\subsubsection{Repository Siting Area}

The limits of the repository siting area are generally described by the Primary Area defined by Mansure and Oritz (Reference 5.8). The Primary Area does not, however, rigidly define limits for repository siting and the siting area may go beyond this boundary provided the limiting criteria are met [Reference 5.2, Key Assumption 022]. The repository siting area assumption is used in Section 7.1.2, Modeling Area.

\subsubsection{Repository Standoff Below Top of RHH}

A 5-m standoff below the top of the RHH was assumed to allow for uncertainty in locating the contact and to provide better roof conditions for any underground excavation that may approach this contact. This assumption is used in Sections 7.3, Repository Host Horizon, 7.5.4, Stratigraphic Considerations, and 7.5.6, Repository Siting Volume. 


\subsubsection{Repository Standoff Above Bottom of RHH}

A 10-m standoff above the bottom of the RHH was assumed to allow for imprecise location of the contact and to avoid excavating into the vitrophyre. This assumption is used in Sections 7.3, Repository Host Horizon, 7.5.4, Stratigraphic Considerations, and 7.5.6, Repository Siting Volume.

\subsubsection{Groundwater Standoff}

It is stated in 10 CFR 960 (Section 4.4.1) that a favorable groundwater condition for disposal in the unsaturated zone is where the water table will be sufficiently below the repository block such that the fully saturated voids continuous with the water table do not encounter the repository [10 CFR $960, \S 960.4-2-1(5)(\mathrm{ii)})$. For this analysis, an assumption was made that a minimum 100-m distance from the repository to the top of the groundwater table is an adequate standoff. This assumption is used in Sections 7.5.3, Groundwater Considerations, and 7.5.6, Repository Siting Volume.

\subsubsection{Subsurface Fault Standoff}

The available repository siting area will be constrained to avoid Type I faults, as defined by the NRC (Reference 5.14). Where avoidance is impractical, the repository design will need to allow for waste packages to be offset to avoid Type I faults. Avoidance of Type I faults is assumed to be adequate by using a $60-\mathrm{m}$ offset from the main trace of a Type I fault at the repository level. One exception to this is that a 120-m standoff was used on the west side of the Ghost Dance Fault [Reference 5.2, Key Assumption 023]. This assumption is used in Sections 7.5.5, Fault Considerations, and 7.5.6, Repository Siting Volume.

\subsubsection{Type I Faults}

For the purpose of defining the repository siting block where adjacent to major faults, the following faults within the study area are assumed to be Type I faults:

- Solitario Canyon fault and associated splays

- Ghost Dance fault

- Abandoned Wash fault and associated splay

- Dune Wash fault

- Pagany Wash fault

- Bow Ridge fault

- Imbricate faults

The Drill Hole Wash fault, once thought to be a major fault in the area, is now considered to be minor based on observations in the ESF tunnel. The description of the fault, as encountered in the ESF tunnel, is presented in the ESF North Ramp tunnel mapping document (Reference 5.44). The Sundance fault has likewise been determined to be of less significance than originally thought (Reference 5.21). The imbricate faults are included as Type I because they are believed to be tectonically related to the Bow Ridge fault. This assumption is used in Sections 7.5.5, Fault Considerations, and 7.5.6, Repository Siting Volume. 


\subsubsection{Subsurface Fault Projection}

Fault locations on the surface were taken from recent mapping (Reference 5.48) and fault dips for projecting these faults to the subsurface were taken from the same mapping, if available. If dips were not shown, then it was assumed that the fault dips at $80^{\circ}$ for normal faults and vertical for strike-slip faults. The assumed $80^{\circ}$ dip was based on a general representative average of dips identified on the mapping. Normal faults dip in the direction shown on the mapping. This assumption is used in Section 7.1.6, Fault Modeling.

\subsection{CODES AND STANDARDS}

\subsubsection{CFR, Title 10, Part 960}

Nuclear Waste Policy Act of 1982; General Guidelines for the Recomendation of Sites for Nuclear Waste Repositories; Final Siting Guidelines, January 1, 1996.

\section{REFERENCES}

5.1 Buesch, D.C., R.W. Spengler, T.C. Moyer, and J.K. Geslin, Proposed Stratigraphic Nomenclaturē and Macroscopic Identification of Lithostratigraphic Units of the Paintbrush Group Exposed at Yucca Mountain, Nevada, U.S. Geological Survey Open-File Report 94$469,1996$.

5.2 Controlled Design Assumptions Document, B00000000-01717-4600-00032 REV 04.

5.3 Technical Data Parameter Dictionary, YMP/93-18, REV 0, ICN 1.

5.4 Reference Information Base, YMP/93-02 REV 3, ICN 1.

5.5 Davis, J.C., Statistics and Data Analysis in Geology, John Wiley \& Sons, New York, 1986.

5.6 LYNX User Documentation, Version 3.0, Volume 1, System Operation, Lynx Geosystems Inc., September 1994.

5.7 Archive Tape for LYNX Design Model YMP.MO3Q, BCA000000-01717-0200-00007, REV 00, Batch Number Moy-970414-09.

5.8 Mansure, A.J. and T.S. Ortiz, Preliminary Evaluation of the Subsurface Area Available for a Potential Nuclear Waste Repository at Yucca Mountain, Sandia Report SAND84-0175, 1984.

5.9 ESF Layout Calculation, BABEAD000-01717-0200-00003 REV 4.

5.10 Johnstone, J.K., R.R. Peters, and P.F. Gnirk, Unit Evaluation at Yucca Mountain, Nevada Test Site, Summary Report and Recommendation, Sandia Report SAND83-0372, 1984. 
5.11 Nimick, F.B. and R.L. Williams, A Three-Dimensional Geologic Model of Yucca Mountain, Southern Nevada, Sandia Report SAND83-2593, 1984.

5.12 Definition of Repository Block Limits, BC0000000-01717-0200-00004 REV 00.

5.13 Definition of Potential Repository Block, BC0000000-01717-5705-00009 REV 00.

5.14 McConnell, K.I., M.E. Blackford, and A-K Ibrahim, Staff Technical Position on Investigations to Identify Fault Dispacement Hazards and Seismic Hazards at a Geologic Repository, U.S. Nuclear Regulatory Commission NUREG-1451, 1992.

5.15 TS North Ramp Geology Design Analysis, BAAAA0000-01717-0200-00001 REV 00.

5.16 Scott, R.B. and J. Bonk, Preliminary geologic map of Yucca Mountain with geologic sections, Nye County, Nevada, U.S. Geological Survey Open-File Report 84-494, 1984.

5.17 Ortiz, T.S., R.L. Williams, F.B. Nimick, B.C. Whittet, and D.L. South, $A$ Three-Dimensional Model of Reference Thermal/Mechanical and Hydrological Stratigraphy at Yucca Mountain, Southern Nevada, Sandia Report SAND84-1076, 1985.

5.18 Lappin, A.R.; R.G. VanBuskirk, D.O. Enniss, S.W. Butters, F.M. Prater, C.S. Muller, and J.L. Bergosh, Thermal Conductivity, Bulk Properties, and Thermal Stratigraphy of Silicic Tuffs from the Upper Portion of Hole USW G-1, Yucca Mountain, Nye County, Nevada, Sandia Report SAND81-1873, 1982.

5.19 Rautman, C.A., Potential Problems with Topopah Spring Stratigraphy, Letter dated December 11, 1985 to Scott Sinnock, RPC No. NNA.910506.0065.

5.20 Peck, J.M, U.S. Clanton, C.A. Rautman, R.W. Spengler, and D. Vaniman, Core Evaluation to Determine Contacts between Thermal-Mechanical Units TSw1 and TSw2, Letter dated May 15, 1991 to D.C. Dobson and J.R. Dyer, RPC No. NNA.910530.0125.

5.21 Potter, C.J., R.P. Dickenson, and W.C. Day, Nature and Continuity of the Sundance Fault, Yucca Mountain, Nevada, U.S. Geological Survey Administrative Report, 1995.

5.22 Noble, D.C., S.I. Weiss and E.H. McKee, Magmatic and Hydrothermal Activity, Caldera Geology, and Regional Extension in the Western Part of the Southwestern Nevada Volcanic Field in Geology and Ore Deposits of the Great Basin Symposium Proceedings, Reno, v. 2, Geological Society of Nevada, 1991.

5.23 Sawyer, D.A., R.J. Fleck, M.A. Lanphere, R.G. Warren, D.E. Broxton, and M.R. Hudson, Episodic Caldera Volcanism in the Miocene Southwestern Nevada Volcanic Field: Revised Stratigraphic Framework, ${ }^{10} A r{ }^{\beta 9} A r$ Geochronology, and Implications for Magmatism and Extension, Geological Society of America Bulletin, v. 106, p. 1304-1318, 1994.

5.24 Scott, R.B., Tectonic Setting of Yucca Mountain, Southwestern Nevada in Basin and Range Extensional Tectonics near the Latitude of Las Vegas, Nevada, Geological Society of 
Title: Determination of Available Volume for Repository Siting Document Identifier: BCA000000-01717-0200-00007, Rev. 00

Page: 13 of 81

America Memoir 176, 1990.

5.25 Moyer, T.C. and J.K. Geslin, Lithostratigraphy of the Calico Hills Formation and Prow Pass Tuff (Crater Flat Group) at Yucca Mountain, Nevada, U.S. Geological Survey Open-File Report 94-460, 1995.

5.26 Price, R.H., F.B. Nimick, J.R. Connolly, K. Keil, B.M. Schwartz, and S.J. Spence, Preliminary Characterization of the Petrologic, Bulk, and Mechanical Properties of a Lithophysal Zone Within the Topopah Spring Member of the Paintbrush Tuff, Sand Report SAND84-0860, 1985.

5.27 Ross, C.S. and R.L. Smith, Ash-Flow Tuffs: their Origin, Geologic Relations, and Identification, U.S. Geological Survey Professional Paper 366, 1960.

5.28 Rautman, C.A. and D.A. Engstrom, Geology of the USW SD-7 Drill Hole, Yucca Mountain, Nevada, Sandia Report SAND96-1474, 1996.

5.29 Engstrom, D.A. and C.A. Rautman, Geology of the USW SD-9 Drill Hole, Yucca Mountain, Nevada, Sandia Report SAND96-2030, 1996.

5.30 Rautman, C.A. and D.A. Engstrom, Geology of the USW SD-12 Drill Hole, Yucca Mountain, Nevada, Sandia Report SAND96-1368, 1996.

5.31 A 3D Geologic Framework and Integrated Site Model of Yucca Mountain: Version ISMI.0, B00000000-01717-5700-00002 REV 1.

5.32 Q-List, YMP/90-55Q REV 4.

5.33 Spengler, R.W., C.A. Braun, L.G. Martin, and C.W. Weisenberg, The Sundance fault: a Newly Recognized Shear Zone at Yucca Mountain, Nevada, U.S. Geological Survey OpenFile-Report 94-49, 1994.

5.34 Repository Design Requirements Document, YMP/CM-0023, REV 0, ICN 1.

5.35 Mined Geologic Disposal System Requirements Document, B00000000-00811-1708-00002 REV 02, DCN 01.

5.36 Spengler, R.W., W.C. Hunter, and D.C. Buesch, Computer-Assisted Stratigraphic Synthesis: A Progress Report, U.S. Geological Survey Administrative Report, 1993.

5.37 Buesch, D.C., J.E. Nelson, R.P. Dickerson, and R.W. Spengler, Development of 3-D Lithostratigraphic and Confidence Models at Yucca Mountain, Nevada, in Proceedings of the Fourth International High-Level Radioactive Waste Management Conference, American Nuclear Society, v. 1, 1993.

5.38 Hayes, L., Early Submittal of 3-D Site Scale Lithostratigraphic Model, Letter dated May 11, 1994 to $\mathrm{S}$. Jones. 
5.39 Distribution of Lithostratigraphic Units within the Central Block of Yucca Mountain, Nevada, Version YMP.R I.I, U.S. Geological Survey Milestone Report 3GGU135M, 1994.

5.40 Buesch, D.C., J.E. Nelson, R.P. Dickerson, R.M. Drake, R.W. Spengler, J.K. Geslin, T.C. Moyer, and C.A. San Juan, Distribution of Lithostratigraphic Units within the Central Block of Yucca Mountain, Nevada: A Three-Dimensional Computer-Based Model, Version YMP.R2.0, U.S. Geological Survey Open-File Report 95-124, 1996.

5.41 Lipman, P.W., R.L. Christiansen, and J.T. O.Connor, A Compositionally Zoned Ash-Flow Sheet in Southern Nevada, U.S. Geological Survey Professional Paper 524-F, 1966.

5.42 Smith, R.L., Zones and Zonal Variations in Welded Ash Flows, U.S. Geological Survey Professional Paper 354-F, 1960.

5.43 Byers, F.M. Jr, W.J. Carr, P.P. Orkild, W.D. Quinlivan, and K.A. Sargent, Volcanic Suites and Related Cauldrons of Timber Mountain-Oasis Valley Caldera Complex, Southern Nevada, U.S. Geological Survey Professional Paper 919, 1976.

5.44 Barr, D.L., T.C. Moyer, W.L. Singleton, A.L. Albin, R.C. Lung, A.C. Lee, S.C. Beason, and G.L.W. Eatman, Geology of the North Ramp - Stations 4+00 to 28+00, Exploratory Studies Facility, Yucca Mountain Project, Yucca Mountain, Nevada, Bureau of Reclamation and U.S. Geological Survey, 1996.

5.45 Yucca Mountain Project Stratigraphic Compendium, B00000000-01717-5700-00004, REV 02 .

5.46 Existing Boreholes from $T D B$, Technical Data Base listing of borehole coordinates dated 02/06/97.

5.47 Buesch, D.C., C.L. Zimmerman, and J.R. Wunderlich, Survey of Three Lithostratigraphic Contacts in Solitario Canyon for Stratigraphic and Structural Control in Verification and Enhancement of Bedrock Geologic Maps for Yucca Mountain, Nevada, Ed W.C. Day and C.D.M. Corbett, U.S. Geological Survey Administrative Report, 1995.

5.48 Day, W.C., C.J. Potter, D.S. Sweetkind, R.P. Dickerson, and C.A. San Juan, Bedrock Geologic Map of the Central Block Area, Yucca Mountain, Nye County, Nevada, U.S. Geological Survey Administrative Report, 1996.

5.49 Forensic Evaluation of Geophysical Log Data for Borehole USW G-2 in Support of the Yucca Mountain Site Characterization Project, BAAA00000-01717-0200-00010, REV. 00.

5.50 Forensic Evaluation of Geophysical Logs from Borehole UE-25 UZ\#5 in Support of the Yucca Mountain Site Characterization Project, BAAA00000-01717-0200-00002, REV. 00.

5.51 Forensic Evaluation of Geophysical Logs from Borehole USW UZ7a in Support of the Yucca Mountain Site Characterization Project, BAAA00000-01717-0200-00004, REV. 00. 
Title: Determination of Available Volume for Repository Siting

5.52 Forensic Evaluation of Geophysical Logs from Borehole USW SD-9 in Support of the Yucca Mountain Site Characterization Project, BAAA00000-01717-0200-00005, REV. 00.

5.53 Forensic Evaluation of Geophysical Logs from Borehole USW SD-12 in Support of the Yucca Mountain Site Characterization Project, BAAA00000-01717-0200-00006, REV. 00.

5.54 Forensic Evaluation of Geophysical Logs from Borehole USW SD-7 in Support of the Yucca Mountain Site Characterization Project, BAAA00000-01717-0200-00007, REV. 00.

5.55 Forensic Evaluation of Geophysical Log Data for North Ramp Geologic Boreholes in Support of the Yucca Mountain Site Characterization Project, BAAA00000-01717-020000008, REV. 00.

5.56 Forensic Evaluation of Geophysical Log Data for Water Table Borehole USW WT-2, USW WT-10, UE-25 WT\#12 in Support of the Yucca Mountain Site Characterization Project, BAAA00000-01717-0200-00009, REV. 00.

5.57 Forensic Evaluation of Geophysical Log Data for Boreholes UE-25 UZ-16 (VSP2) in Support of the Yucca Mountain Site Characterization Project, BAAA00000-01717-020000011 , REV. 00.

5.58 Forensic Evaluation of Geophysical Log Data for Borehole USW UZ-14 in Support of the Yucca Mountain Site Characterization Project, BAAA00000-01717-0200-00012, REV. 00.

5.59 Ervin, E.M., R.R. Luchey, and D.J. Burkhardt, Revised Potentiometric-Surface Map, Yucca Mountain and Vicinity, Nevada, U.S. Geological Survey Water-Resources Investigations Report 93-4000, 1994.

5.60 ISM2.0: A 3D Geologic Framework and Integrated Site Model of Yucca Mountain, B00000000-01717-5700-00004, REV 00.

5.61 Brocoum, S.J., Borehole Geophysical Data Technical Assessment, Letter dated August 29, 1995 to L.D. Foust, DOE AMSL:CMN-4340.

5.62 Albin, A.L., W.L. Singleton, T.C. Moyer, A.C. Lee, R.C. Lung, G.L.W. Eatman, and D.L. Barr, Geology of the Main Drift - Station 28+00 to 55+00, Exploratory Studies Facility, Yucca Mountain Project, Yucca Mountain, Nevada, Bureau of Reclamation and U.S. Geological Survey, 1997.

5.63 ESF/GROA Interface, B00000000-01717-0200-00124, REV 01. 


\section{USE OF COMPUTER SOFTWARE}

\subsection{QUALIFIED SOFTWARE}

Much of this design analysis centered around the use of the Lynx Geoscience Modeling software (LYNX), version 3.06. This software is a three-dimensional, volume-based geology and engineering computer modeling system developed by Lynx Geosystems, Inc. of Vancouver, B.C., Canada. LYNX was qualified in 1995 and carries the Computer Software Configuration Item (CSCI) number B00000000-01717-1200-30018. The software is mounted on a Silicon Graphics Indigo2 workstation running the IRIX 5.3 operating system. The workstation is equipped with High Impact graphics, 250 MHz R4400 processor, and 256 Mbytes of RAM. It is located in Subsurface Repository Design and has the CRWMS-M\&O tag \#700709. The software was originally obtained to specifically perform this type of work and was qualified with that intent in mind. The software is appropriate for the application used in this design analysis, was not used outside the range of qualification, and was obtained from Software Configuration Management (SCM) according to procedures.

\subsection{NON-QUALIFIED SOFTWARE}

Various non-qualified software products were also used during the course of this design analysis to assist in organizing, managing, manipulating, comparing, and displaying data and information. This includes commercial, off-the-shelf software and UNIX shell scripts written to perform specific conversion tasks (Table 1). These software are used to perform support activitities and are not used as the controlled source of information for the design analysis, as defined in QAP-SI- 0 . They are therefore not required to be qualified under these procedures. Source code listings of the UNIX shell scripts are provided in Attachment VIII.

\section{DESIGN ANALYSIS}

\subsection{COMPUTER GEOLOGY MODELING}

Much of this design analysis is based on a 3-dimensional computer geology model developed using the LYNX Geoscience Modeling software (Section 6.1). This computer model is identified in LYNX as YMP.MO3Q and is referred to herein as the Design Model. It was developed by M\&O Repository Design specifically for this design analysis and was based on interpretations of qualified and non-qualified data available from core logging, geophysical logging, geologic mapping, lab analyses, and ESF tunnel mapping.

LYNX is a 3-dimensional, volume-based, geologic and mine modeling software system (Reference 5.6). The tools included in the software consist of borehole database and data retrieval, 2dimensional data display and manipulation, graphical display, geology volume modeling, underground excavation modeling, volumetric analysis, statistical/geostatistical analysis, and 3dimensional visualization. The graphical tools provide for the presentation of project data in a variety of different contexts and formats. Key to the graphical display is the concept of the view plane, which can be thought of as a window through which one can view the data from different 
Table 1. Non-qualified software used in this design analysis.

\begin{tabular}{|c|c|c|}
\hline PLATFORM & SOFTWARE & USE \\
\hline \multicolumn{3}{|c|}{ COMMERCIAL OFF-THE-SHELF SOFTWARE } \\
\hline \multirow[t]{3}{*}{ 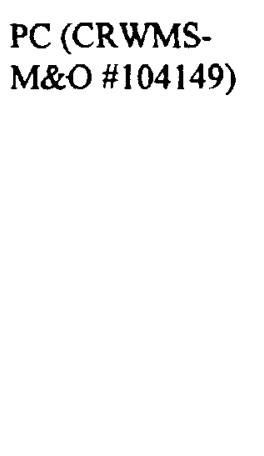 } & $\begin{array}{l}\text { Excel, Ver. } 5.0 \mathrm{a} \\
\quad \text { Microsoft Corp. }\end{array}$ & $\begin{array}{l}\text { Spreadsheet program used to compile and } \\
\text { manipulate borehole data in preparation for } \\
\text { input to Lynx database }\end{array}$ \\
\hline & $\begin{array}{l}\text { FTP32, Ver. } 95.01 .01 \\
\text { Ipswitch, Inc. }\end{array}$ & $\begin{array}{l}\text { File transfer program used to transfer Excel } \\
\text { output text files from the PC to the Silicon } \\
\text { Graphics workstation. }\end{array}$ \\
\hline & $\begin{array}{l}\text { QLA 2, Ver. } 2.2 \\
\text { GeoGraphix, Inc. }\end{array}$ & $\begin{array}{l}\text { Geophysical log analysis program used to } \\
\text { display borehole geophysical digital data as } \\
\text { logs and cross plots. }\end{array}$ \\
\hline $\begin{array}{l}\text { SGI UNIX } \\
\text { Workstation } \\
\text { (CRWMS-M\&O } \\
\# 700709 \text { ) }\end{array}$ & $\begin{array}{l}\text { CorelDraw!, Ver. } 3 \\
\text { Corel Corp. }\end{array}$ & $\begin{array}{l}\text { Graphics program used to develop figure } \\
\text { illustrations for the design analysis. }\end{array}$ \\
\hline \multicolumn{3}{|c|}{ UNIX SHELL SCRIPTS } \\
\hline \multirow[t]{3}{*}{$\begin{array}{l}\text { SGI Workstation } \\
\text { (CRWMS-M\&O } \\
\# 700709 \text { ) }\end{array}$} & YMP.MO3Q/misc/fixdholefile & $\begin{array}{l}\text { Format Excel output text files for input to } \\
\text { LYNX database. Code listed in Attachment } \\
\text { VIII. }\end{array}$ \\
\hline & $Y M P . M O 3 Q / m i s c / d x f 2 m a p . a w k^{1}$ & $\begin{array}{l}\text { Extracts } d x f \text { file ENTITIES data into LYNX } \\
\text { map ASCII file format. Code listed in } \\
\text { Attachment VIII. }\end{array}$ \\
\hline & $\begin{array}{l}Y M P . M O 3 Q / m i s c / e 2 m- \\
\text { map.awk }\end{array}$ & $\begin{array}{l}\text { Convert LYNX map files in English units to } \\
\text { metric units. Code listed in Attachment VIII. }\end{array}$ \\
\hline
\end{tabular}

${ }^{\mathrm{I}}$ These script files are often modified to address specific applications.

vantage points. The viewplane is defined by the northing and easting coordinate for the lower left corner, the elevation of that corner, the azimuth of the bottom edge, and the inclination of the left edge from the vertical. The flexibility of the viewplane concept allows for the viewing of models from virtually any position.

\subsubsection{Previous Computer Geology Models}

Computer geology modeling has been conducted on the project since the early 1980's by Sandia National Laboratories and more recently by the U.S. Geological Survey, M\&O Repository Design, and $\mathrm{M} \& \mathrm{O}$ Site Evaluation and Program Operations.

Sandia National Laboratories built the first model (Sandia Model) using their own internallydeveloped three-dimensional interactive computer graphics modeling system (Reference 5.11). This 
system used a method of analytically interpolating between sparce and irregularly-spaced data points located in three-dimensional space to define continuously gridded trend surfaces. The modeling technique involved constructing the surfaces in pre-faulted conditions, then 'faulting' them to their present predicted positions based on fault offset estimates. This modeling system was used in constructing the intitial three-dimensional model of the reference thermal/mechanical and hydrological stratigraphy presented by Ortiz and others (Reference 5.17), and for identifying the potential repository siting areas presented by Mansure and Ortiz (Reference 5.8). This model is no longer used, having been replaced by more recently developed detailed models.

The U. S. Geological Survey (USGS) began its computer modeling work in 1992 using the LYNX system. Their initial model, YMP.R0, was a demonstration model of the central block (References 5.36 and 5.37) and was released in early 1993. It was constructed from reference cross sections and borehole data available at that time. Eighteen boreholes and 43 cross sections were used in building this model. For validation purposes, ten boreholes were omitted during construction of the model so they could be used later to check the validity of the modeled surfaces.

Also in 1993, M\&O Repository Design acquired the LYNX system for modeling support of repository and ESF design. After qualifying the software for QA work, modeling was started. The first model, YMP.MO0, was used in part to generate input to the TS North Ramp Geology Design Analysis (Reference 5.15). This model consisted of cross sections along the ESF alignment and some limited modeling of surfaces from the Sandia Model.

The second computer model produced by the USGS used the surface modeling techniques in LYNX rather than the cross sectional techniques used in the previous demonstration model. This new model was released early in 1994 as YMP.R1.0 (Reference 5.38) to demonstrate the surface modeling technique that was to be used on future models. The surface modeling technique enabled easier updating and transfer of the model to other computer modeling systems. The final version of this model was then released later in 1994 as YMP.R1.1 (Reference 5.39). This model presented the major block faults as dipping planes and included eleven lithostratigraphic units. Thirty-seven boreholes were used in constructing the model. Isopach maps were constructed from the borehole and other available information, then surfaces were built by subtracting the individual unit thickness from the reference structure surface at the base of the Tiva Canyon Tuff. This reference structure surface was selected because it had the greatest amount of data for control.

The second model to be built by M\&O Repository Design was YMP.MO2, which was developed in 1995. This model was used to generate input to the Definition of the Potential Repository Block (Reference 5.13) and was built with the application of the surface modeling techniques in LYNX. The model development was based initially on the USGS Models YMP.R1.0 and YMP.R1.1, but was then modified to reflect new data not included in the USGS model and to include alternate interpretations and modeling techniques. Major faults were modeled as inclined planes. Instead of modeling the lithostratigraphy as in YMP.R1.1, the YMP.MO2 model was built on the thermal/mechanical surfaces, including TSw1, TSw2, and TSw3. In most cases, these surfaces were modeled as coinciding with lithostratigraphic surfaces except the top of TSw2, which was identified within the upper lithophysal zone of the Topopah Spring Tuff based on geophysical log interpretation. The top of the TSw2 unit used in this 1995 report is equivalent to the top of the top of the Repository Host Horizon defined in this report. The criteria used to identify this surface is identified in the 1995 report (Reference 5.13) and is detailed in Section 7.3 of this design analysis. 
The last update to the USGS model was released in 1996 and was identified as version YMP.R2.0 (Reference 5.40). This model added additional new borehole data for SD-9 and SD-12, revised data for NRG-4 and NRG-5, and added other information not in the previous model. Two additional lithostratigraphic surfaces were also added to bring the total number of surfaces in the model to thirteen.

In 1996, the M\&O Site Evaluation and Program Operations assumed the modeling responsibility for the project from the USGS. In order to coordinate modeling efforts, a Numerical Model Warehouse concept was initiated to store and retrieve computer models created on the project, and to provide for a mechanism for distribution of standard project models. This standard project model, known as the Integrated Site Model (ISM), Version 1.0 (ISM1.0 Model), is comprised of the 3D Geologic Framework Model and a set of rock properties models and data sets (Reference 5.31). Initial ISM modeling was completed in the LYNX system, then the data files were converted and uploaded to the Earthvision software system. The ISM covers an area of $166 \mathrm{sq} \mathrm{km}$ and includes over thirty modeled rock unit surfaces. In comparison, the Design Model covers an area of only about $14 \mathrm{sq}$ $\mathrm{km}$ and includes seven stratigraphic surfaces. The ISM1.0 Model could not be used in the current design analysis because the model covers a wide area and lacks detail in the central block where the repository design work is concentrated and all the faults are portrayed as vertical planes.

An update to the ISM1.0 Model was being constructed concurrent with the building of the Design Model. This new ISM update was released in February, 1997 (Reference 5.60) and added new detail to the previous ISM model of the central block area. This model also characterized faults as dipping planes to better approximate their actual position in the subsurface. The information in this new model, ISM2.0, has not been incorporated in the current Design Model because the majority of the development work on the Design Model had to be completed prior to the approval of the ISM2.0 Model. Examination of preliminary maps and sections shows that the Design Model and ISM2.0 Model are very similar, but they do have some significant differences locally that are mainly a result of different borehole lithostratigraphic contact picks and different extrapolation trends. As identified in Attachment II, the Design Model incorporated the same borehole depth picks used in the ISM2.0 Model, except where geophysical logs indicated a different depth pick should be used. In most cases, these were minor differences of a few meters, but some are as great as $55 \mathrm{~m}$ (borehole WT-18, Attachment II). A more analytical comparison of these two models is not possible at this time because the LYNX output files from the ISM2.0 Model are not yet available. For the next iteration of the ISM model, ISM3.0, the Design Model will be incorporated and the differences reconciled so that there will be one geologic model framework for describing the site. The geology core and cuttings picks for the boreholes are also being evaluated with the available geophysical logs to identify consistent picks that can be used in future modeling. This will alleviate one of the biggest sources of differences in the current modeling efforts.

\subsubsection{Modeling Area}

The Design Model covers an area of approximately 14 square kilometers and is bounded on the west by the Solitario Canyon fault, the northeast by the Pagany Wash fault, the east by the western-most imbricate faults, and the southeast by the Dune Wash and Abandoned Wash faults (Figure 1). To the south, the area is truncated near borehole GU-3 where the area becomes restricted between the Solitario Canyon fault and southern extension of the imbricate faults (not shown in Figure 1). The model area covers most of the structural block referred to as the central block. Significant faults 


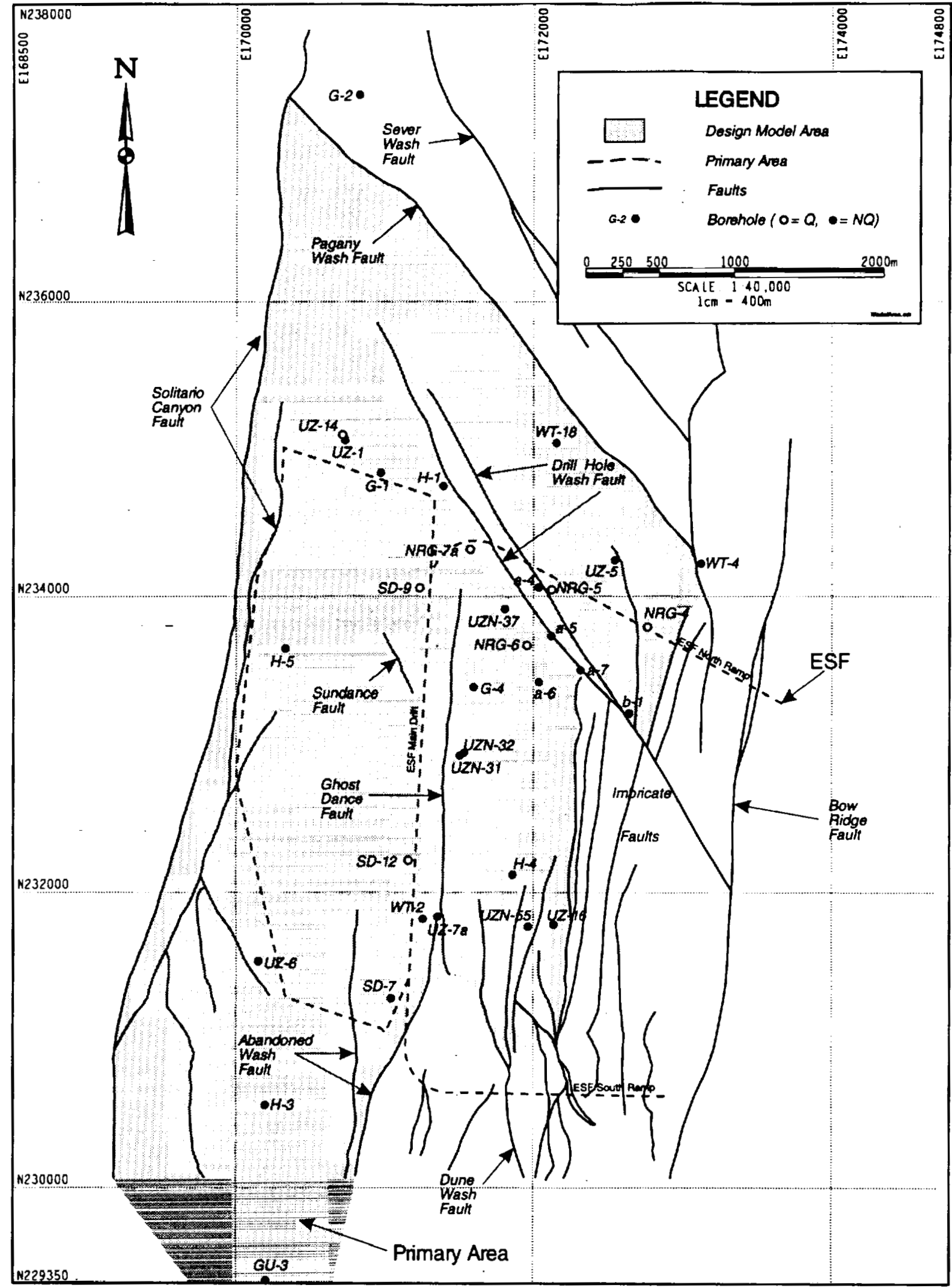

Figure 1. Design Model area shown in relation to the Primary Area. Limits for the Design Model are shown along with the ESF and boreholes used in the Design Model. 
contained within the central block include the Ghost Dance and Drill Hole Wash faults. The model area generally covers the Primary Area (Assumptions, Section 4.3.3), as defined by Mansure and Ortiz (Reference 5.8), except in the north where the model area was extended beyond the Primary Area to the Pagany Wash fault (Figure 1). This northern expansion was included to explore the possible extension of the repository block north of Drill Hole Wash fault.

\subsubsection{Topography Modeling}

The topographic coverage for the modeling area was obtained from the TDB in 1993 and was based on original 1:6,000-scale topographic maps (Reference 5.4, Section 1.11). The data were supplied in drawing interchange file ( $d x f$ ) format (Design Parameters, Section 4.1.1) and is the basis for the topography assumption (Assumptions, Section 4.3.1). The map data were first converted to metric, then converted to Lynx map ASCII file format using UNIX shell scripts described in Section 6.2. The ASCII file was then uploaded to the Design Model as a LYNX map. Because of LYNX system file size limitations, the map area was divided into nominal $2000-\mathrm{m}$ square areas, each of which was retrieved into separate files. Corner elevation points were interpolated to provide added control. Each map was then thinned to remove closely spaced data points and the areas recontoured using the LYNX contouring facility. The new contour interval was $5-\mathrm{m}$, which is slightly less than the original input map contour interval of $20-\mathrm{ft}$. To verify the results, the new metric maps were superimposed on the original English unit maps and the contour patterns compared. The resulting maps provided a good and representative topographic coverage for the modeling area, but since the original maps were non-qualified (Reference 5.4, Section 1.11), the resulting maps are also nonqualified. These maps were then used to generate surface volumes to represent the topographic surface. A list of the maps for the topography are presented in Attachment $\mathrm{V}$ and their corresponding volume models are listed in Attachment VI. The topography, thinned to $20-\mathrm{m}$ contours, is shown in Figure 2. The location of the ESF tunnel is shown for reference and the surface features are identified.

\subsubsection{Overburden Modeling}

To define the repository cover limits, contour maps were built for the minus 200-m overburden surfaces. This surface defines the upper limit for repository siting according to the minimum repository cover criteria (Criteria, Section 4.2.1). According to 10 CFR 960 (Codes and Standards, Section 4.4.1, §960.4-2-5(d)), the site shall be disqualified if site conditions do not allow all portions of the underground facility to be situated at least $200 \mathrm{~m}$ below the directly overlying ground surface. The topographic maps were first downloaded to ASCII files and contours were eliminated to result in contours with $20-\mathrm{m}$ intervals. Each topographic contour line was then lowered in elevation by $200 \mathrm{~m}$, then loaded back into the Design Model. The resulting contour maps represented the surface $200 \mathrm{~m}$ below the topography and are classified as non-qualified because their source was also nonqualified (Reference 5.4, Section 1.11). These maps were then used to generate surface volumes that represent the surface with constant overburden.

It is also identified in 10 CFR 960 (Codes and Standards, Section 4.4.1, $\$ 960.4-2-5(b)$ ) that a favorable condition is one that permits the emplacement of waste at a depth of at least $300 \mathrm{~m}$ below the directly overlying ground surface. For this reason, the same type of maps and surface volumes were generated for the minus $300-\mathrm{m}$ surface below the topographic surface. 


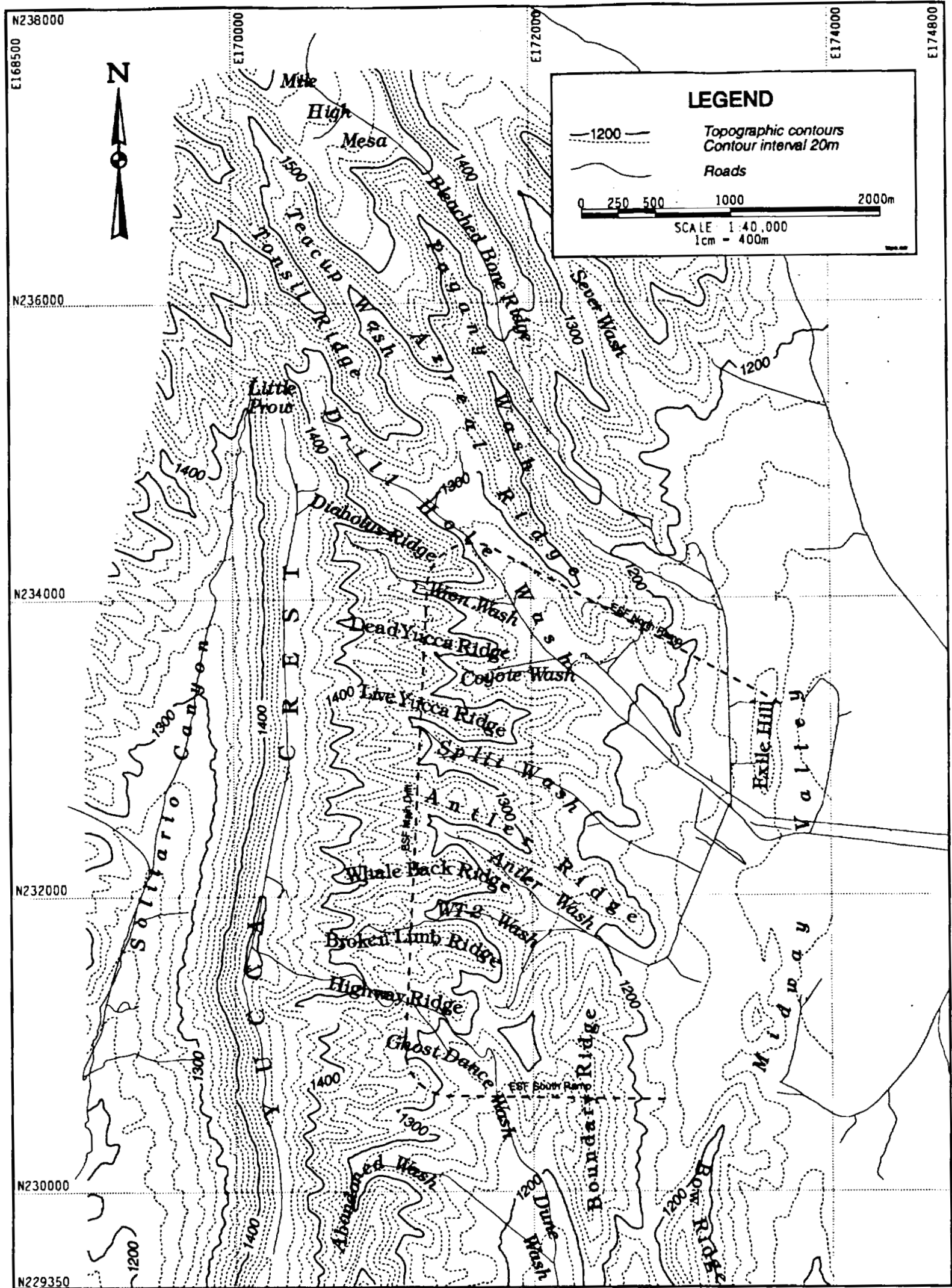

Figure 2. Topography for the Design Model area. 
A list of the maps and volumes for the overburden are listed in Attachments V and VI. The contour map on the 200-m overburden surface is shown in Figure 3. The location of the ESF tunnel is also shown for reference.

\subsubsection{Stratigraphy Modeling}

The stratigraphy was modeled using the best borehole, ESF mapping, and outcrop geologic data available at the time. The Design Model is based on certain premises that form the foundation for the model. These premises characterize the vertical and lateral variability of the rock unit and its relationship to the units below and above it. The design premises are as follows:

1) The Topopah Spring Tuff was deposited on an irregular, erosional surface with at least $100 \mathrm{~m}$ of local relief (Reference 5.41, pg. F3). An ash flow that is deposited on uneven topography tends to fill in the low areas so that the bottoms are irregular and the tops are nearly level (Reference 5.27, pg. 23).

2) The source direction of the Topopah Spring Tuff was from the Timber Mountain, OasisValley, and Silent Canyon caldera complexes to the north of Yucca Mountain (References 5.22 and 5.23). Therefore, regional thickness trends for the Topopah Spring Tuff tend to be more consistent in an east-west direction, thin rapidly towards the north, and thin gradually towards the south (References 5.41, pg. F3-F4 and 5.43, pg. 22-23). Local thickness trends may, however, be entirely different because they may follow irregularities in the topographic surface upon which the tuff was deposited.

3) The Topopah Spring Tuff resulted from the rapid deposition of a hot avalanche-like mass or particulate flow (Reference 5.42). It is a compound cooling unit that was emplaced rapidly, but with several brief interruptions during its emplacement so that the lower parts of the deposit began to partially cool before the total deposit was emplaced (Reference 5.41, pg. F2). Compound cooling is indicated by the repetition of vaporphase and lithophysal zones and by the presence of densely welded zones overlying porous vapor-phase zones (Reference 5.41, pg. F7).

Based on these three premises, the stratigraphy was modeled for the thermal/mechanical units TSw1, TSw2, and TSw3; the crystal-poor lithostratigraphic units contained within the TSw2 unit, including the middle nonlithophysal zone (Tptpmn), lower lithophysal zone (Tptpll), and lower nonlithophysal zone (Tptpln); and the Repository Host Horizon (RHH) (Figure 5).

Based on the first premise above, the reference surface from which all the stratigraphic surfaces were built was the top of TSw1, the upper-most unit modeled. This surface is within the mass of the Topopah Spring Tuff that was deposited very rapidly (Premise 3 above) and is considerably below the base of the Tiva Canyon Tuff, the reference surface used in the USGS and ISM modeling. The top TSwl surface was selected over the bottom Tiva Canyon Tuff surface because the TSwl unit was not affected by paleoerosion within the model area and it is an easily-recognized and sharp contact below the nonwelded top of the Topopah Spring Tuff. The bottom of the Tiva Canyon Tuff would be affected by pre-Tiva erosion and the irregular depositional patterns of the Pah Canyon and Yucca Mountain Tuff units overlying the Topopah Spring Tuff. 


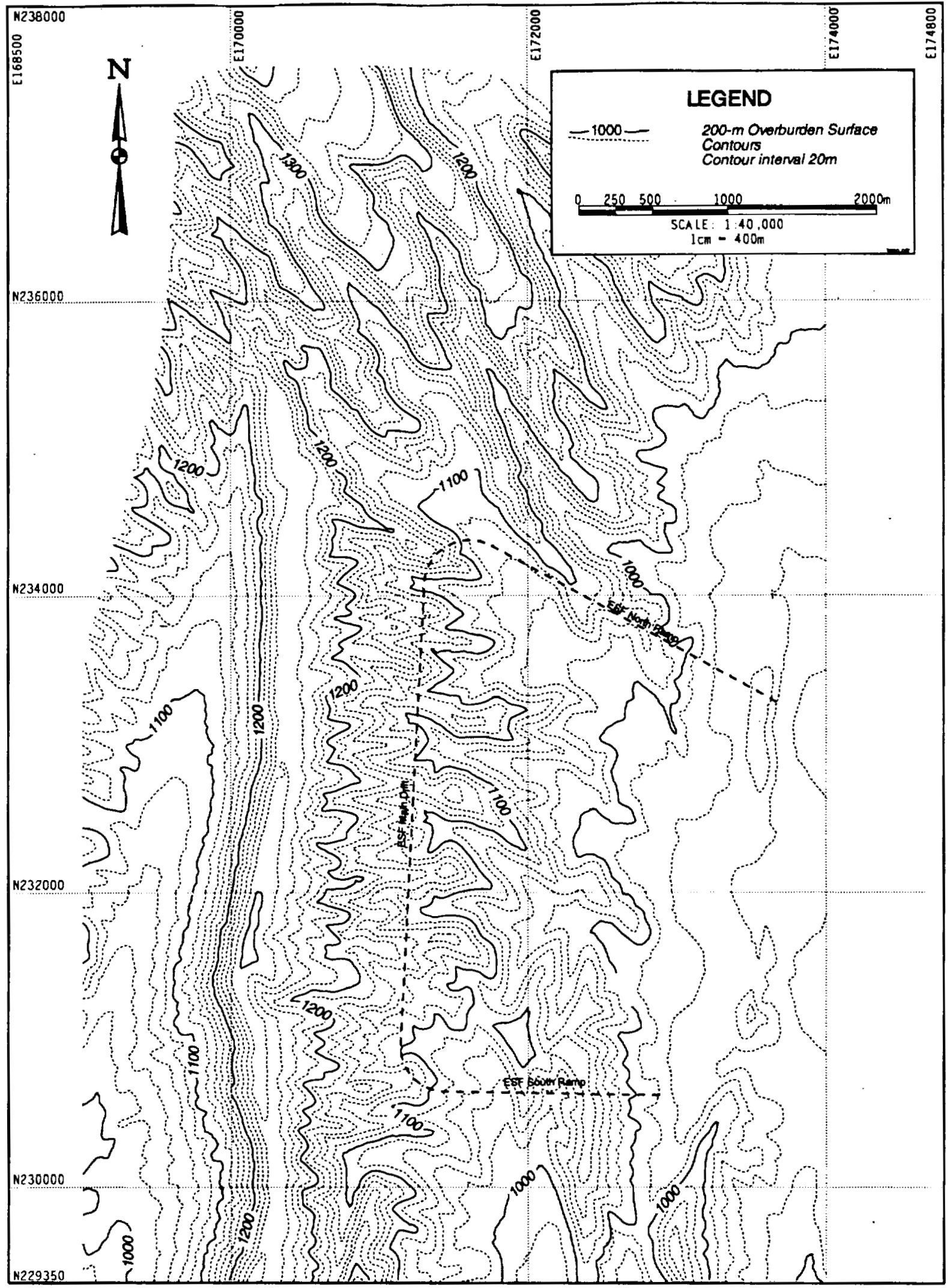

Figure 3. Contour map on 200-m overburden surface. 
A structure contour map for the top of the TSwl unit was first built by hand contouring the borehole data and Solitario Canyon outcrop data. The map contours were 'forced' to define a surface as planar as possible (by mentally removing the influence of the structural dip of the beds) while at the same time honoring all the data points. Once complete, a surface model was then built from this contour map. The top of TSw2 unit was then likewise modeled, using the TSwl surface as a reference and honoring all the data points. A surface model was then built for the TSw2 top surface, and a thickness volume was built by subtracting the lower surface from the upper surface. A thickness contour map was then built and smoothed to create a map with reasonable geological features. A new structural surface was then created by subtracting the new thickness map from the upper structural surface. The thicknesses were then contoured to form the final thickness map. This same procedure was then repeated for the other surfaces in the model. With increasing depth, the structural surfaces became more complex and reflected the erosional surface upon which the Topopah Spring Tuff was laid. The structural surfaces and thickness maps created for the model are listed in Attachment V and their corresponding models are listed in Attachment VI.

The contouring method selected for initially developing the surfaces for modeling was, as discussed in the previous paragraph, hand contouring. This method is the most appropriate method to use in the situation at Yucca Mountain. Hand contouring reflects the geologist's concepts and ideas of what the surface should look like based on the limited data points from boreholes and outcrops, and the geologist's understanding of the depositional history and pattern of the deposit. On the other hand, computer-drawn contours are built from a computer-developed mathematical model of the surface and does not take into account the depositional history and pattern of the deposit. The mathematical model may be constructed by Delaunay triangulation procedures, as is the case with LYNX, or from a grid generated by various mathematical algorithms for trend surface generation, such as kriging, least-squares, or moving averages (Reference 5.5, pgs 353-430). Where the data points are widely spaced and separated by faults, as is the case at Yucca Mountain, computer modeling fails without adding numerous 'dummy' boreholes to control the development of the model. It was for this reason, and the ability to represent the geologist's concept of the surface, that hand contouring was selected.

The LYNX system uses the Delaunay triangulated network (TIN) surface for modeling and develops contours by linear interpolation along the sides of the triangle with B-spline smoothing (Reference 5.6, pg 4-40). LYNX does not use an algorithm for trend surface analysis, so the contours were adjusted by hand to more realistically represent the geologist's concept of the surface. Because of the widely-spaced data points at Yucca Mountain, the triangulated surfaces can often times be very large, thereby creating unrealistic surface trends. Building the TIN surfaces from contours supplemented with the borehole and outcrop data points helps alleviate these modeling problems and gives a more realistic model.

\subsubsection{Fault Modeling}

Faults are modeled as planar surfaces with constant dip down to an elevation of approximately $500 \mathrm{~m}$. Where surface dip measurements or subsurface control are not available, the dip was assumed to be 80 degrees, with the dip direction taken from surface mapping information (Assumptions, Section 4.3.9). The technique used for modeling of the faults involved a series of steps to most accurately represent the faults. The fault traces on the surface were taken from the recent mapping by Day and others (Reference 5.48), uploaded to the Design Model as a $d x f$ file. The 
fault traces were 'draped' over the topography to generate a traverse line with an elevation value assigned to each point on the trace. The view plane was then tilted to an inclined position perpendicular to the dipping surface, and the traverse line was duplicated at an elevation of $500 \mathrm{~m}$. Tilting the view plane back to horizontal then yielded a traverse line defining the intersection of the fault with the topography and a second traverse line defining the 'bottom' of the fault, now at some elevation off of $500 \mathrm{~m}$. Each fault was modified to fit with any faults against which it is truncated or merged. Surface volume models were then created to represent each fault surface. The fault maps created for the model are listed in Attachment V, and their corresponding surface volume models are listed in Attachment VI.

\subsubsection{Groundwater Modeling}

The most recently available description of the subsurface hydrology is presented in the RIB (Reference 5.4, Section 1.612). This document presents a contour map drawn on the potentiometric surface and is based on 1993 data from 28 boreholes, 14 of which are in the vicinity of the Design Model area. This map, however, did not present contours for the total model area. In order to model the potentiometric surface, the contours had to be extrapolated into the noncontoured areas using available, but sparse data. To provide some control in the far northern part of the area, water depth data for borehole G-2 was included from the Yucca Mountain Project Stratigraphic Compendium (Reference 5.45). The data used in the construction of the potentiometric surface map are listed in Attachment III and the contour map is illustrated in Figure 4 (Design Parameters, Section 4.1.6).

\subsubsection{ESF Modeling}

An engineering model of the ESF was included with the Design Model to provide a point of reference when viewing the model (Design Parameters, Section 4.1.7). The ESF model was constructed using the underground engineering modeling tools available within LYNX. The controlling coordinate geometry was obtained from the ESF Layout Calculation (Reference 5.9). LYNX is limited in the geometry of features that may be input, therefore the cross section of the tunnel was modeled to closely represent the designed cross section, while having a cross sectional area scaled to the actual design area. The starter tunnel was excavated by the drill and blast mining method, so it has a different cross section than the tunnel excavated by the tunnel boring machine (TBM). The starter tunnel is from Station $0+00$ to $0+60$ and has a horseshoe shape cross section, $8.8 \mathrm{~m}$ wide and $8.8 \mathrm{~m}$ high. It was modeled as a rectangle for the bottom section and the upper half of an octagon for the upper curved section. The TBM bore, which extends from Station $0+60$ to the south portal is $7.62 \mathrm{~m}$ in diameter. It was modeled as an octagon.

\subsubsection{Reference Repository Analysis Plane Modeling}

The reference repository analysis plane models were developed specifically for analyzing the positioning of the repository blocks within the siting volume, rather than to model a specific repository design. These planes were developed for reference only to demonstrate the repository siting volume and are based on the repository design documented in Reference 5.63. Two analysis planes were constructed, one for the upper repository level and one for the lower repository expansion level. The upper level is anchored along the main drift of the ESF, which provided for two of the control points for defining the plane. The third point was obtained by calculating the 


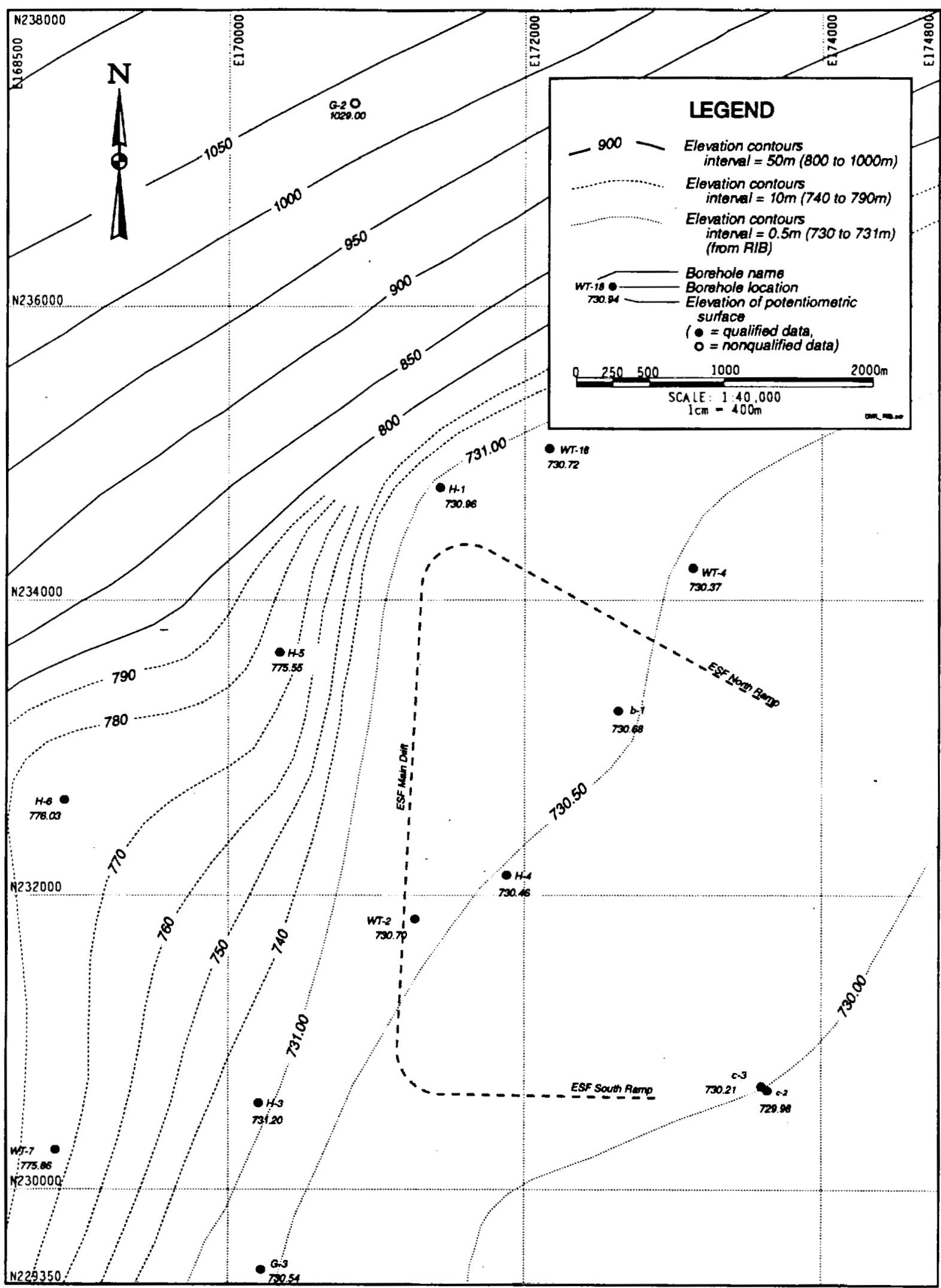

Figure 4. Potentiometric surface contours drawn on 1993 average groundwater level data. 
coordinates of a point at the end of an emplacement drift as shown in the ESF/GROA interface (Reference 5.63). Invert elevations were used in the calculation and once constructed, the plane was verified with additional points calculated for other points in the repository. A plane was also constructed for the lower repository expansion level based on elevations presented in the ESF/GROA interface (Reference 5.63). The LYNX definition of the planes for the upper and lower repository blocks at their invert elevations is shown in Table 2. Planes for the crown level were also developed by adding $7.62 \mathrm{~m}$ to both invert planes.

Table 2. LYNX plane definition for the repository block analysis planes at their invert elevations.

\begin{tabular}{|c|c|c|}
\cline { 2 - 3 } \multicolumn{1}{c|}{} & $\begin{array}{c}\text { Upper Repository } \\
\text { Invert Plane }\end{array}$ & $\begin{array}{c}\text { Lower Repository } \\
\text { Expansion Invert } \\
\text { Plane }\end{array}$ \\
\hline Northing $^{1}$ & 234087.742 & 233702.003 \\
\hline Easting $^{1}$ & 171313.778 & 171563.932 \\
\hline Elevation $^{1}$ & 1065.00 & 998.00 \\
\hline Azimuth $^{2}$ & 288.00 & 288.00 \\
\hline Inclination $^{3}$ & $\mathbf{8 9 . 1 9 9 5}$ & $\mathbf{8 9 . 1 9 9 5}$ \\
\hline
\end{tabular}

${ }^{1}$ Northing, easting, and elevation of the viewplane origin (lower left comer).

${ }^{2}$ Azimuth is the horizontal angle of the bottom edge of the viewplane measured from the north and with the axis at the origin. ${ }^{3}$ Inclination is the vertical angle of the viewplane hinged along the bottom edge of the viewplane and measured from the vertical

\subsubsection{Design Model Disposition}

The Design Model was submitted to the Numerical Model Warehouse and the RPC for storage and retrieval (Reference 5.7). A directory listing of the files is presented in Attachment VII. Since this model was constructed in the LYNX software system, any viewing and manipulation of the model would require the use of a licensed LYNX or LYNXVIEW software system. The model was constructed in version 3.06 of the LYNX software, but any later version should have the capability to read and display the model. If any later versions of the LYNX software is used, the system will automatically convert the files to that necessary for the new version. The component files that make up the Design Model are identified in Attachments IV, V and VI.

\subsection{STRATIGRAPHY}

Yucca Mountain is comprised of a thick sequence of welded and nonwelded, silicic ash-flow tuffs with minor units of bedded and air-fall tuffs. This volcanic sequence is part of the middle Miocene southwestern Nevada volcanic field that was emitted during a period from 7.5 to $>15$ million years ago from the overlapping Timber Mountain, Oasis Valley, and Silent Canyon caldera complexes to 
the north of Yucca Mountain (Reference 5.23). The volcanic rocks exposed on the surface and at the depth of the repository belong to the Paintbrush Group of Miocene age (Figure 5). The Paintbrush overlies the Calico Hills Formation, a heterogeneous sequence of nonwelded ash-flow tuffs, bedded tuffs, lava flows, air-fall tuffs, and other tuffaceous sediments. The repository is sited within the Topopah Spring Tuff of the Paintbrush Group.

Two stratigraphic nomenclature systems are commonly used on the project and are an integral part of this design analysis. The lithostratigraphy system is a process-based system that emphasizes depositional and compositional characteristics with secondary emphasis on degree of welding, crystallization characteristics, depositional features, and fracture characterisitics (Reference 5.1). For engineering purposes, the lithostratigraphy has been combined into thermal/mechanical stratigraphic units, which is property based and combine rocks with similar thermal and mechanical characteristics (Reference 5.17). The thermal/mechanical units are equivalent to the hydrogeologic units included in the Q-List as natural barriers (Reference 5.32).

\subsubsection{Lithostratigraphy}

The initial detailed description of the lithostratigraphy of Yucca Mountain was developed by Scott and Bonk (Reference 5.16), who mapped the exposed rock units in the region, and described and subdivided them based on petrologic and weathering characteristics of their surface exposures. After the Yucca Mountain site was designated in 1987 as the only site for characterization, more concentrated work was performed in the immediate area of Yucca Mountain with detailed surface mapping and subsurface exploration through core drilling. Direct observation, mapping and analysis of the subsurface rock has recently been provided by the large-diameter bore of the Exploratory Studies Facility (ESF) tunnel boring machine (TBM). These additional sources of data provided the foundation for the revision to the stratigraphic nomenclature of the Paintbrush Tuff, as proposed by Buesch and others (Reference 5.1). This scheme elevated the Paintbrush Tuff to group status and some from member to formation status. The formation nomenclature level identifies rocks that collectively are interpreted to have formed from the same eruptive event. This detailed lithostratigraphic nomenclature, as used on the project, is presented in the RIB (Reference 5.4, Section 1.12). For the purpose of siting the repository, the main lithostratigraphic units of interest are the Topopah Spring Tuff and its contained subunits.

The typical volcanic rocks of the Paintbrush Group are compositionally-zoned, ashflow sheets that covered a widespread area and were formed during violent, multiple flow, eruptions in rapid succession, so that the mass cooled as one unit. The two thickest formations of the Paintbrush Group, the Tiva Canyon Tuff and Topopah Spring Tuff, are very similar in their composition, character, and distribution (Reference 5.1). These units display a distinct, vertical systematic chemical, mineralogical, petrologic, and structural zonation. From bottom to top, the ash composition grades from crystal-poor rhyolite to crystal-rich quartz latite. Welding varies upward from non-welded to moderately-welded tuff at the base, through the densely welded interior, to a capping of moderately-welded to nonwelded tuff. The densely-welded interior may have a vitrophyre developed at the base and top of the zone, with the interior welded rocks devitrified. The central portion of the welded interior, which contains subzones of lithophysae development, is affected by vapor phase mineralization. 


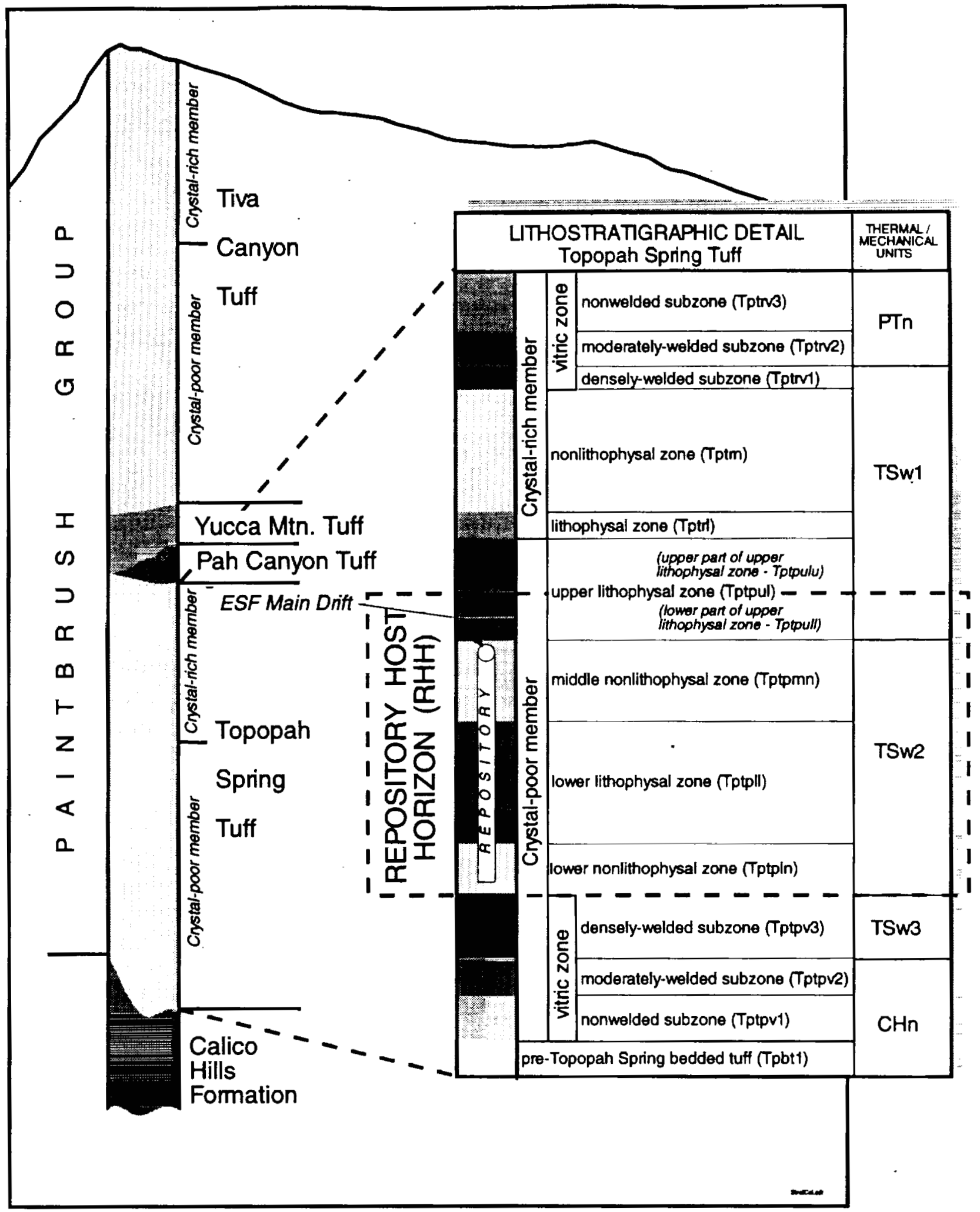

Figure 5. General stratigraphic column for Yucca Mountain showing the lithostratigraphic nomenclature of the Paintbrush Group. Detailed lithostratigraphic and thermal/mechanical nomenclature are shown for the Topopah Spring Tuff. The Repository Host Horizon and stratigraphic position for the ESF main drift and repository are shown on the detailed column. 
The grouping and subdivision of the units by Buesch and others was based on macroscopic criteria, including 1) type and abundance of phenocrysts, 2) features associated with deposition, 3) zones of welding and crystallization, and 4) geometry and surface roughness of fractures. Type and abundance of phenocrysts is the fundamental criterion for subdividing both the Tiva Canyon and Topopah Spring Tuffs into members (Figure 5). The upper member of these two formations is the crystal-rich member, which is characterized by 10 to 15 percent phenocrysts, whereas the lower crystal-poor member has 3 to 10 percent phenocrysts (Reference 5.1).

Within these two members, there are numerous zones and subzones that are subdivided based on welding, crystallization, lithophysae, and fracture characteristics (Figure 5). Welding and crystallization in ashflow tuffs typically follow a general pattern that reflects their deposition and cooling history. The lower-most zone of the ashflow deposit is known as the vitric zone and is subdivided based on welding and crystallization (Reference 5.1). This unit can be subdivided into a nonwelded base, grading upwards through moderately-welded to densely-welded at the top. The densely-welded subzone is often-times present as a thick, densely-welded vitrophyre (Reference 5.1). Occurring at the top of the formations are capping, crystal-rich vitric zones. This zone is a mirror image of the crystal-poor vitric zone at the base, but usually thinner with poorly developed vitrophyre.

The interior section of the ashflow tuffs is comprised of densely-welded, devitrified tuff with vaporphase crystallization and lithophysae development. This section is subdivided into numerous zones based on lithophysae and fracture characteristics (Figure 5). Lithophysal zones developed where trapped gasses and vapors concentrated in layers within this interior densely welded section. The occurrence and distribution of lithophysal zones reflect the compound cooling history of the rock mass. The repetition of the lithophysal zones are a result of extrusive surges separated by brief interruptions (Reference 5.41). The lithophysal zones developed in the upper section of each surge as hot gasses were released from the cooling mass and migrated towards the surface. Vapor-phase crystallization took place through much of the densely-welded section (Reference 5.1).

Lithophysae development is prominent within specific zones of the densely-welded sections in the Tiva Canyon Tuff and Topopah Spring Tuff sections. Lithophysae are hollow, bubble-like structures composed of concentric shells of finely crystalline alkali feldspar, quartz and other minerals (Reference 5.1). In section, they are typically comprised of four components extending out from the center and consisting of: 1) a central cavity, 2) a thin lining of vapor-phase minerals (tridymite, sanidine, magnetite, and rutile), 3) a thick rim of fine-grained crystals, and 4) a thin border of very fine-grained crystals. Most cavities are only a few centimeters across, but some may be as large as a meter. Lithophysae develop during emplacement of the tuff flow deposit and represent vapor concentrations from trapped gasses released from the cooling mass. Commonly associated with the lithophysae are features referred to as 'spots', which are typically 10 to $50 \mathrm{~mm}$ in diameter. They are comprised of three components extending out from the center and consisting of: 1) a central core centered on a crystal, lithic clast, or small isolated area of groundmass, 2) a spot of fine-grained crystals, and 3) a thin border of very fine-grained crystals. Their origin may be similar or related to the formation of lithophysae.

Over the years, there has been considerable confusion associated with the definition of lithophysae and its application to the identification of the rock units designated as lithophysal zones. The USGS 
has used the term lithophysae to include the cavity and its associated alteration rind (Reference 5.19, pg. 2), whereas other workers (References 5.17 and 5.26) used the lithophysae term to include only the cavity and associated lining of vapor-phase minerals. In the early USGS core logs, a lithophysal zone was identified by the presence of cavity-including lithophysae (Reference 5.19) and estimates of percent lithophysae content was based on the four components of lithophysae as described in the preceding paragraph. This usage is in agreement with Ross and Smith (Reference 5.27), who stated that "Lithophysal zones occur where vapor concentrates in the densely welded parts ..... to form lithophysal cavities ...." In the more recent U.S. Geological Survey borehole core logs, this definition of lithophysal zones has changed slightly to more accurately identify the lithophysal zones in core. Buesch and others (Reference 5.1) identified a lithophysal zone by a combined occurrence of lithophysae and spots. They noted that many spots may represent the cross section of rims on lithophysae, whereas others have distinct crystal or lithic fragments in the central core. Rautman and Engstrom (References 5.28, 5.29, and 5.30) used the recommended criteria proposed by Buesch and others when logging the core from the systematic drilling program boreholes (SD-7, SD-9, and SD12). They stated that "lithophysal zones ..... contain rocks exhibiting small- to medium-sized lithophysae and/or spots whose matrix is grayish red-purple in color" and "the matrix of rocks from named nonlithophysal zones is typically more brownish or orangish in color" (Reference 5.28, pg. 18). Lithophysal zones also exhibit distinctive fracturing patterns. Fractures within the lithophysal zones are generally shorter and more irregular in form and exhibit rougher surfaces than those within the nonlithophysal zones.

Most of the surface exposures on Yucca Mountain belong to the Tiva Canyon Tuff, which is the upper-most major unit of the Paintbrush Group (Figure 5). It forms the ridges on the eastern flank of Yucca Crest and the upper part of the cliff face on the western flank. The Tiva Canyon is a multiple-flow, compound cooling unit that displays the composition zoning discussed in previous paragraphs. It has been estimated to have been about $100 \mathrm{~m}$ thick when deposited (Reference 5.24). Directly below the Tiva Canyon Tuff (but included with it in Figure 5) is the pre-Tiva Canyon bedded tuff, which is an air-fall and reworked tuff deposit emplaced prior to the main Tiva canyon pyroclastic flow units (Reference 5.1).

Underlying the Tiva Canyon is a series of relatively thin, simple cooling unit ashflow tuffs and associated, underlying bedded tuffs. These include the Yucca Mountain Tuff and Pah Canyon Tuff (Figure 5), which are discontinuous across the area (Reference 5.1). These ashflow tuffs are mostly nonwelded, but may be more welded where they locally thicken. These units outcrop on the western cliff face of Yucca Crest and in small local areas in the deep washes on the eastern flank. The Yucca Mountain Tuff is up to about $30 \mathrm{~m}$ thick at the project site and the Pah Canyon Tuff is up to about $70 \mathrm{~m}$ thick, but is absent in the far south (Reference 5.1).

The Topopah Spring Tuff underlies the Pah Canyon Tuff and is about $350 \mathrm{~m}$ thick at Yucca Mountain (Reference 5.1). As discussed previously, it is compositionally zoned similar to the younger Tiva Canyon Tuff and has a central welded interior with moderately-welded to nonwelded tuff at the top and bottom. At the base of the welded interior, there is a very thick vitrophyre zone. Like the Tiva Canyon Tuff, there is a bedded tuff unit at the base of the Topopah Spring Tuff that consists of air-fall and reworked tuff deposits. The Topopah Spring Tuff contains the host horizon for the repository within part of its central welded interior. The repository host horizon is shown in Figure 5 and consists of the lower part of the upper lithophysal zone, middle nonlithophysal zone, lower lithophysal zone, and lower nonlithophysal zone. The stratigraphic position of the ESF and 
repository are also shown in Figure 5. The current repository design underground developments are contained entirely within the middle nonlithophysal (Tptpmn), lower lithophysal (TptplI), and lower nonlithophysal (Tptpln) zones.

Underlying the Topopah Spring Tuff is the Calico Hills Formation, which overlies the Prow Pass Tuff, the upper unit of the Crater Flat Group (Reference 5.25). The Calico Hills Formation is comprised of relatively massive, homogeneous, nonwelded ashflow tuffs separated into five units of ash-fall beds that overlie an interval of bedded tuff and a basal volcanoclastic sandstone.

\subsubsection{Thermal/Mechanical Stratigraphy}

For underground engineering design, the stratigraphic nomenclature of most interest is the thermal/mechanical stratigraphy. This scheme was first proposed by Lappin and others (Reference 5.18) to group rocks with similar thermal and mechanical properties. It was reasoned by them that the physical properties of the rock were more directly related to performance assessment and repository design than the classical genetic-process basis of lithostratigraphy. They used grain density and porosity rock properties from borehole G-1 to define their thermal stratigraphy. Subsequent analysis showed that this relationship could be applied to other boreholes as well, and that these same physical properties could also be used to define a mechanical and hydrologic stratigraphy. The resulting nomenclature, referred to as the thermal/mechanical and hydrological stratigraphy, was originally defined by Ortiz and others (Reference 5.17) based on the evaluation of core logs and geophysical logs from 15 boreholes. This scheme is now more commonly known as the thermal/mechanical stratigraphy. They identified 16 thermal/mechanical units, of which six are important to the repository layout design and siting as addressed in this design analysis. These six units include:

- Upper Paintbrush nonwelded unit (PTn)

- Topopah Spring welded unit, lithophysae-rich (TSwl)

- Topopah Spring welded unit, lithophysae-poor (TSw2)

- Topopah Spring welded unit, vitrophyre (TSw3)

- Calico Hills and Lower Paintbrush nonwelded unit (CHn)

The thermal/mechanical units were principally subdivided based on their degree of welding and the presence of significant lithophysae, which correlate with the rock properties of grain density and porosity. Because rock physical properties often reflect genetic processes, the thermal/mechanical units generally correlate with individual or groups of lithostratigraphic zones.

The PTn unit consists of partially welded to nonwelded, vitric and occasionally devitrified tuffs. Included in this unit are the nonwelded tuffs at the base of the Tiva Canyon Tuff, the Yucca Mountain Tuff, the Pah Canyon Tuff, and the moderately to nonwelded tuffs at the top of the Topopah Spring Tuff (Figure 5). Only the latter subunit at the top of the Topopah Spring Tuff is identified in the detailed section shown in Figure 5. The PTn unit is included on the Q-List as part of the natural barrier system (Reference 5.32).

The Topopah Spring welded unit (TSw) underlies the PTn and is subdivided into three units, TSw1, TSw2 and TSw3. The TSw unit is included on the Q-List as part of the natural barrier system (Reference 5.32). The upper-most subunit, TSw1, is densely-welded, generally devitrified, 
lithophysae-rich and includes the following lithostratigraphic zones of the Topopah Spring Tuff (Figure 5): 1) densely-welded (vitrophyre) subzone of the vitric zone (Tptrv1), 2) nonlithophysal zone (Tptrn), 3) lithophysal zone (Tptrl), and 4) upper lithophysal zone (Tptpul). The underlying TSw2 unit, in contrast, is lithophysae-poor, but is also densely-welded and devitrified. It includes the following lithostratigraphic zones of the Topopah Spring Tuff: 1) middle nonlithophysal zone (Tptpmn), 2) lower lithophysal zone (Tptpll), and 3) lower nonlithophysal zone (Tptpln) (Figure 5). The TSw2 unit was originally identified as the host horizon for the repository (Reference 5.8), but due to confusion as to the definition of the unit, part of the overlying TSwl unit is now included along with the TSw2 unit. The total rock section that is now identified as the Repository Host Horizon is shown in Figure 5 and is described in more detail in Section 7.3. The lower TSw3 unit consists entirely of the densely-welded subzone (Tptpv3) of the vitric zone (Figure 5). This is the basal vitrophyre of the Topopah Spring Tuff and ranges in thickness from about 7 to 35 meters.

Underlying the TSw3 unit is the CHn unit (Figure 5). This consists of the lower moderately and nonwelded portion of the Topopah Spring Tuff, the Calico Hills Tuff, the underlying pre-Calico Hills bedded tuff, and the upper nonwelded portions of the underlying Prow Pass Tuff of the Crater Flat Group. Only the first subunit, consisting of the moderately and nonwelded tuff at the base of the Topopah Spring Tuff is illustrated in the detailed section in Figure 5. Ortiz and others subdivided the $\mathrm{CHn}$ unit into three subunits designated $\mathrm{CHn} 1, \mathrm{CHn} 2$ and $\mathrm{CHn} 3$. These subdivisions have not been used in this design analysis. The $\mathrm{CHn}$ unit contains the main zeolitic zone (Reference 5.25). The CHn unit is included on the Q-List as part of the natural barrier system (Reference 5.32).

\subsection{REPOSITORY HOST HORIZON (RHH)}

The rock unit suitable for repository siting has been defined as the TSw2 thermal/mechanical subunit by Oritz and others (Reference 5.17). This definition is included as a key assumption to repository design, but it is now recognized that the lower part of the overlying TSw1 unit may also be suitable (Assumption Section 4.3.2). Over the years, however, there has been considerable confusion as to the definition of the TSw2 unit and how it is to be identified in the actual rock mass. Because of this confusion, it is proposed in this design analysis that the rock unit determined to be most suitable for the repository siting be referred to as the RHH. It consists of the TSw2 unit and the lower part of the TSwl unit.

\subsubsection{Previous Work}

The TSw2 unit, as originally defined by Ortiz and others (Reference 5.17), includes the moderately to densely welded, devitrified ashflows belonging to the Topopah Spring Tuff of the Paintbrush Group that locally contain less than approximately 10 percent by volume of lithophysal cavities. This is in contrast to the overlying TSwl unit, which contains more than approximately 10 percent by volume of lithophysal cavities. The 10 percent criteria is an approximation and was not meant to be an absolute cutoff value. Below the TSw2 unit is the TSw3 unit, which consists of vitrophyre near the base of the Topopah Spring Tuff. This lower contact is easily recognized in core and in the geophysical logs.

Soon after the thermal/mechanical stratigraphy of Ortiz and others (Reference 5.17) was released, Rautman (Reference 5.19) recognized a potential problem with the identification of the contact 
between the TSw1 and TSw2 units. He found that the USGS core descriptions of lithophysae, which Ortiz and others used as a basis in their study, included not only the central cavity, but also the vapor-phase alteration rind surrounding the cavity (see Section 7.2.1). Since the original concept that formed the basis of the work by Ortiz and others was based on lithophysal cavities, and the data they used for determining borehole depth picks included the cavity and the surrounding alteration rim, there were resulting errors of over $120 \mathrm{~m}$ for their contact picks between the TSwI and TSw2 units. After reexamination of the core to estimate only the cavity portion of the lithophysae, revised depths for boreholes G-1, G-2, GU-3 and G-4 were given by Rautman (Reference 5.19). A comparison of these depths is included in Table 3, Columns A and B.

In 1991, a committee evaluation was conducted to determine the location of the TSwl/TSw2 contact in several boreholes (Reference 5.20). Based on this evaluation, revised depths were determined for the TSw1/TSw2 contact. These new picks for the geology (G) boreholes are listed in Table 3, Column C. The stratigraphic picks for the TSw1/TSw 2 contact that were selected by the committee closely agreed with the picks identified by Ortiz and others in boreholes GU-3 and G-4, however, the committee pick for borehole G-1 was considerably different than those selected by Ortiz and others. Based on its evaluation, the committee concluded that the TSw1/TSw 2 contact is equivalent to the lithologic contact recognized by the USGS as the top of the middle nonlithophysal zone of the Topopah Spring Tuff, a consistent contact across the area that is easily recognized in core. This, in effect, redefined the TSw1 and TSw2 thermal/mechanical units to coincide with "easily-recognized" process-based lithostratigraphic units, thereby abandoning the basic concept of the property-based thermal/mechanical units, while at the same time retaining the nomenclature and usage. The basis for their conclusion also differs from the earlier observation of Rautman (Reference 5.19), who identified that Ortiz and others actually identified their contact on 10 percent lithophysae, rather than cavities, as they thought they were doing.

Table 3. Comparison of TSw1/TSw2 contact depth picks and the top of the RHH for geology (G) boreholes in the Central Block. All depths are in meters.

\begin{tabular}{|c|c|c|c|c||c|}
\cline { 2 - 5 } & $\begin{array}{c}\text { A (1985) } \\
\text { Ortiz and } \\
\text { others } \\
\text { (Ref. 5.17) }\end{array}$ & $\begin{array}{c}\text { R(1985) } \\
\text { Rautman } \\
\text { (Ref. 5.19) }\end{array}$ & $\begin{array}{c}\frac{\mathbf{C} \text { (1991) }}{\text { Peck and }} \\
\text { others } \\
\text { (Ref. 5.20) }\end{array}$ & $\begin{array}{c}\text { D(1996) } \\
\text { Framework } \\
\text { Model } \\
\text { ISM1.0 } \\
\text { (Ref. 5.31) }\end{array}$ & $\begin{array}{c}\text { E(1997) } \\
\text { Top of } \\
\text { Repository } \\
\text { Host Horizon } \\
\text { (this analysis) }\end{array}$ \\
\hline G-1 & 304 & 183 & 218 & 217 & $183^{2}$ \\
\hline G-2 & 455 & $347^{5}$ & N/D & 381 & $345^{3}$ \\
\hline GU-3 & 210 & 207 & $210-219^{1}$ & 222 & $209^{3}$ \\
\hline G-4 & 204 & 183 & 207 & 207 & $188^{4}$ \\
\hline
\end{tabular}

I Upper and lower contacts were chosen to envelope a 9-meter transition zone.

${ }^{2}$ Questionable geophysical log. Pick based on lithophysal cavity estimate.

${ }^{3}$ Geophysical log/lithophysal cavity estimate pick.

${ }^{4}$ Geophysical log pick.

${ }^{5}$ Questionable pick. 
As originally stated by Ortiz and others (Reference 5.17), the key defining criteria that separates the TSw2 unit from the overlying TSwl unit is the relative content of lithophysal cavities. In the TSwl unit, the lithophysal cavities generally account for greater than approximately 10 percent by volume, whereas in the TSw2, they generally account for less than approximately 10 percent by volume. Since both the TSwl and TSw2 units include nonlithophysal zones which do not contain any appreciable lithophysae, this criteria obviously applies only to the lithophysal portions of these units. But even within the lithophysal zones, the criteria does not absolutely hold true. The '10-percent' criteria was intended to be used only as a general guideline and is not a hard and fast rule.

As detailed in a previous technical document concerning the determination of available volume for repository siting (Reference 5.13), there was an easily-recognized bulk density log signature that closely corresponds to the TSw1/TSw2 depth picks of Rautman (Table 3, Column B). This contact occurrs about 10 to $45 \mathrm{~m}$ above the TSw1/TSw2 contact as defined by the committee (Reference 5.20). This contact, referred to in this design analysis as the top of the RHH, is illustrated in Figure 6 for borehole SD-9, where the contact was identified at a depth of $191.41 \mathrm{~m}(628.0 \mathrm{ft})$. In this illustration, it can be seen that this contact is characterized by a noticeable change in average apparent bulk density. This change in density also corresponds to a change in estimated lithophysal cavities. This contact corresponds more closely (within 2 to $5 \mathrm{~m}$ ) to the picks by Rautman (Table 3, Column B), who, also identified the TSw1/TSw2 contact based on lithophysal cavity content, but used the estimates of lithophysal cavities rather than the geophysical logs.

It is believed that this upper contact, referred to herein as the top of the RHH, more accurately identifies the significant change in physical characteristics that form the basis for the thermal/mechanical stratigraphy concept than does the top of the middle nonlithophysal zone as proposed by the committee. But, to avoid further confusion as to the definition of the TSw1/TSw2 contact, it is proposed that the rock unit determined to be suitable for repository siting be referred to as the RHH. The top of the RHH, then, is at the contact depth identified by the bulk density log and lithophysal cavity estimate histogram, and is situated within the upper lithophysal zone and lower part of the TSwl unit.

\subsubsection{Definition of the RHH Top Contact}

The lithophysal cavity histogram, presented in Figure 6 for borehole SD-9, illustrates very well the typical relationship of the cavity content to the top of the RHH. The estimates of lithophysal cavities were obtained by comparing the surface area of core and core-video images occupied by actual cavities with standard charts for estimating mineral percentages in thin sections (Reference 5.29). These estimates are for smaller lithophysal cavities that can be recognized and measured in the core. Lithophysal cavities that are significantly larger than the core diameter or sufficiently large to result in rubblized core are not included in the estimates. It is recognized that lost core and the presence of rubble may be associated with large-diameter lithophysal cavities (Reference 5.1). When compared with the estimated lithophysal cavity content, the histogram for lost core and rubble generally corresponds to, but amplifies, the small lithophysal cavity histogram (Reference 5.29).

In the lithophysal cavity histogram (Figure 6), it can be seen that the top contact of the RHH was identified at a depth of $191.41 \mathrm{~m}(628.0 \mathrm{ft})$, where the estimate of small lithophysal cavities dropped from about six percent immediately above the contact to three percent below the contact. Although this is below the '10-percent' guideline, it is the location of a significant decrease in lithophysal 


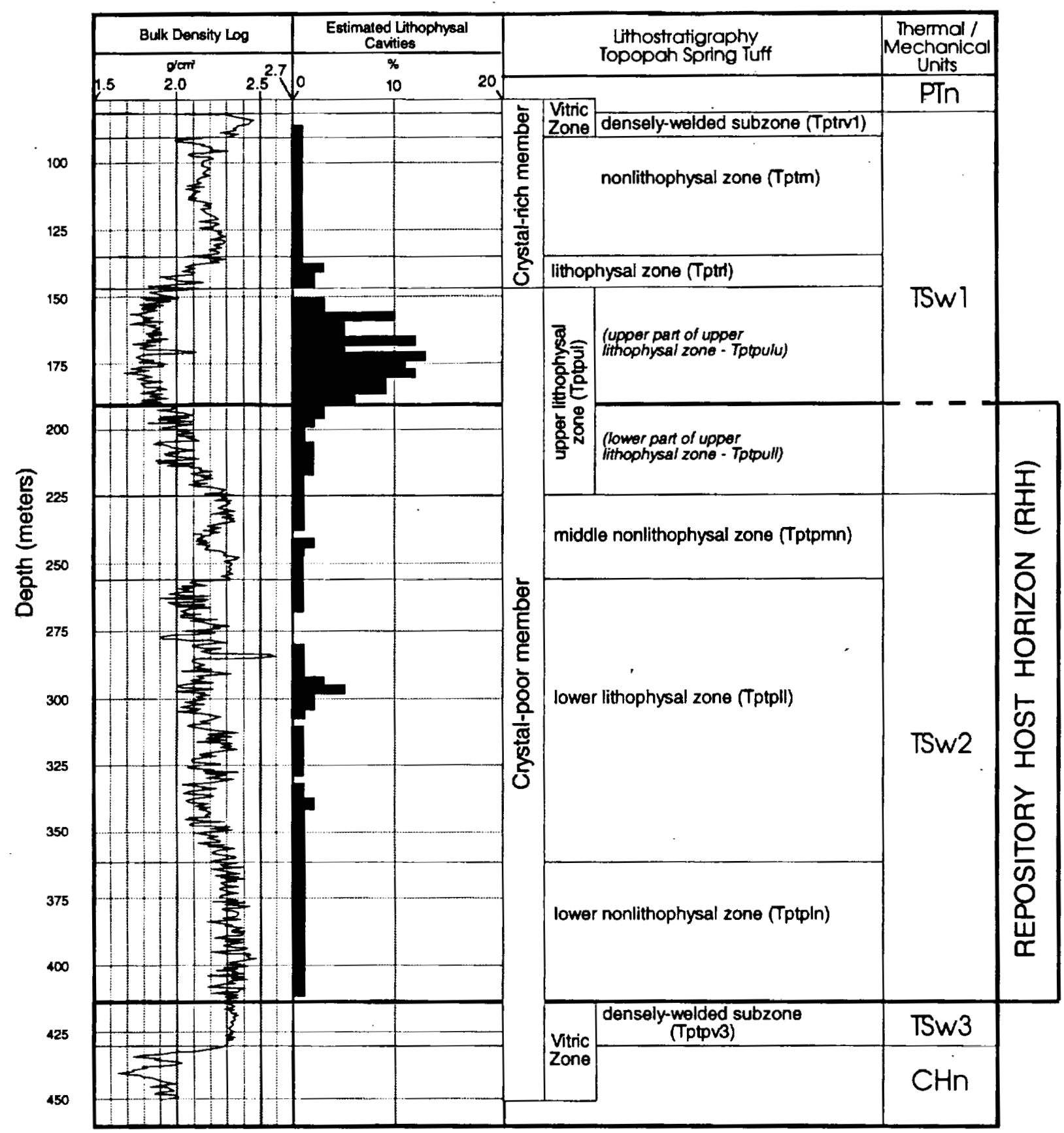

Figure 6. Borehole SD-9 bulk density log and estimate of lithophysal cavities from core. Lithostratigraphic and thermal / mechanical units are shown with the Repository Host Horizon identified. Geophysical log data are from Reference 5.52 and estimate of lithophysal cavities data are from Reference 5.29. 
cavities. Below the contact, the cavities average from 1 to 2 percent, while above the contact, they average about 8 percent. If lost core and rubble was factored in, the average lithophysal cavities in the rock overlying the RHH would increase well above the '10-percent' guideline.

The bulk density log is most useful in identifying the top contact of the RHH, as well as the rest of the contacts within the Topopah Spring Tuff welded units. In the example illustrated in Figure 6, the top RHH contact is selected as the top of the transition zone from the lower density rocks above to the higher density rocks below. In the example, the apparent density for the lithophysal rocks above the contact averages less than $2 \mathrm{~g} / \mathrm{cc}$, while below the contact, the lithophysal rocks average greater than $2 \mathrm{~g} / \mathrm{cc}$. Bulk density logs for other boreholes show similar relationships and average values, although the values may not be identical.

Although the top RHH contact was not logged as such in the core log for borehole SD-9 (Reference 5.29), its location can be recognized based on the core log description. Near the $191.41 \mathrm{~m}(628.0$ $\mathrm{ft}$ ) contact depth, at $191.32 \mathrm{~m}(627.7 \mathrm{ft})$, the log notes that lithophysae intensity decreases (less crowded) downward. Within the $188.24 \mathrm{~m}(617.6 \mathrm{ft})$ to $216.80 \mathrm{~m}(711.3 \mathrm{ft})$ depth interval, very large lithophysae were recognized in the borehole video. Below the contact, the lithophysae recovered in the core are noticeably smaller and less numerous.

Because the bulk density logs available for the remainder of the boreholes in the modeling area are of varying quality, identification of the top contact of the RHH by geophysics alone met with varying success. Notes on the quality of the pick in each borehole are included in Attachment II. The bulk density logs from the North Ramp Geology (NRG) boreholes and the Systematic Drilling (SD) boreholes were generally very good and provided well-defined contact picks. In these boreholes, except SD-7, estimates of lithophysal cavities were comparable to the bulk density log. In several other boreholes, including UZ-1, UZ-16, WT-2, WT-4, and b-1, the top of the RHH was very well defined in the bulk density logs. In the Geology $(\mathrm{G})$ boreholes, the contact was identifiable in the bulk density logs, but weakly so, and depended on the estimates of lithophysal cavities to place some reliability on the bulk density log pick. The top RHH bulk density log contact pick for the four Hydrology $(\mathrm{H})$ boreholes were all questionable, as well as for boreholes UZ-6 and WT-18. In two boreholes, UZ-7a and UZ-14, the top of the RHH could not be identified because of the poor quality of the bulk density log. Perhaps more detailed analysis and enhancement of the available bulk density logs could improve the reliability of these picks.

In the ESF tunnel, the top RHH contact is located at about Station $23+25$, as identified from rock descriptions in the tunnel mapping (Reference 5.44). Above this location, the unit is characterized by small- to medium-sized ( 5 to $7.5 \mathrm{~cm}$ long), ellipsoidal lithophysae (cavity and alteration rim) that comprise an estimated 10 to 25 percent of the rock. Locally, where fracturing of the rock is intense, the lithophysae are commonly up to about three times larger and comprise 30 to 40 percent of the rock.

Below the top RHH contact in the ESF tunnel at Station 23+25, lithophysae comprise an estimated 15 to 30 percent of the rock, deminishing to 10 to 15 percent after Station $25+62$. Below the RHH contact, the unit is characterized by a bimodal size distribution of lithophysae. The smaller lithophysae are generally less than $8 \mathrm{~cm}$ long and are elongated, which imparts a moderately welldeveloped foliation. The lithophysae of the larger subset are generally greater than $11 \mathrm{~cm}$, but may be as large as $60 \mathrm{~cm}$ long. In contrast, the rocks in the underlying middle nonlithophysal zone 
starting at Station $27+20$, contain generally less than 2 percent lithophysae.

One apparent difference stands out when comparing the tunnel mapping with the core estimates. The estimates in the tunnel are considerably greater than the estimates from core. The tunnel mapping described lithophysae as composed of cavity and alteration rim, so the percentages would be significantly higher than that estimated from core, which included only the cavity. Also, it is likely that the larger viewing area of the tunnel will yield better estimates than core from a borehole.

The top of the RHH has also been recognizable in surface exposures of the section, although it is not documented. On Fran Ridge, located to the southeast of the model area, a change in lithophysal cavity characteristics can be seen above the heater block test site. There, in the expected approximate position above the top of the middle nonlithophysal zone, the lithophysal cavities change upward in the section from large and widely spaced to small and numerous. This change in the characteristics of the lithophysal cavities is thought to identify the top of the RHH.

\subsubsection{Description of TSw1 Unit above RHH}

The TSw1 thermal/mechanical unit overlies the TSw2 unit. The lower part of the TSw1 unit forms the upper portion of the RHH (Figure 5). The TSw1 unit is generally lithophysae-rich, as defined by Ortiz and others (Reference 5.17), but it actually contains both nonlithophysal and lithophysal rocks. It includes the densely-welded (vitrophyre) subzone of the vitric zone (Tptrv1), nonlithophysal zone (Tptrn), lithophysal zone (Tptrl), and the upper lithophysal zone (Tptpul). Overlying the TSwl unit are the nonwelded rocks of the PTn thermal/mechanical unit. In this design analysis, the lower part of the upper lithophysal zone lying below the top of the RHH is discussed in the next section.

The TSw1 unit above the RHH ranges in thickness from less than $50 \mathrm{~m}$ in the south to over $110 \mathrm{~m}$ in the area of borehole NRG-7a (Figure 7). The maximum thickness area is elongated east-west and thins southward. To the northeast, it thins rapidly towards borehole WT-4. Towards the northwest, it thins more gently towards borehole G-2. The TSwl unit outcrops along the southern part of Solitario Canyon, but is in fault contact to the north.

The top contact of the TSwl unit is characterized on the bulk density log as a sharp and dramatic step from the overlying very low-density PTn rocks to the high-density vitrophyre (Tptrvl) subzone at the top of the TSwl unit (Figure 6). Below the thin vitrophyre subzone in borehole SD-9, the density curve decreases from about $2.4 \mathrm{gm} / \mathrm{cm}^{3}$ in the vitrophyre to between 2.1 and $2.3 \mathrm{gm} / \mathrm{cm}^{3}$ in the underlying nonlithophysal zone (Tptrn). The nonlithophysal zone is estimated to contain less than one percent lithophysal cavities. Below this nonlithophysal zone is a thick lithophysal section that is subdivided into the crystal-rich lithophysal zone (Tptrl) at the top followed by the crystal-poor upper lithophysal zone (Tptpul). The capping crystal-rich lithophysal zone shows a rapid downwards decrease in density as the lithophysal cavities increase in volume. The upper portion of the upper lithophysal zone contains the most extensive lithophysal cavity development in the Topopah Spring Tuff section. In SD-9, estimated cavity occurance reaches a high of about 13 percent and averages 6.3 percent, as estimated from the core (Table 4). The bulk density log reflects the increase in voids as the density drops to an average of $1.92 \mathrm{gm} / \mathrm{cm}^{3}$ (Table 5). The spiking nature of the bulk density signature, ranging from 1.73 to $2.27 \mathrm{gm} / \mathrm{cm}^{3}$, reflects the nature of the rock, 


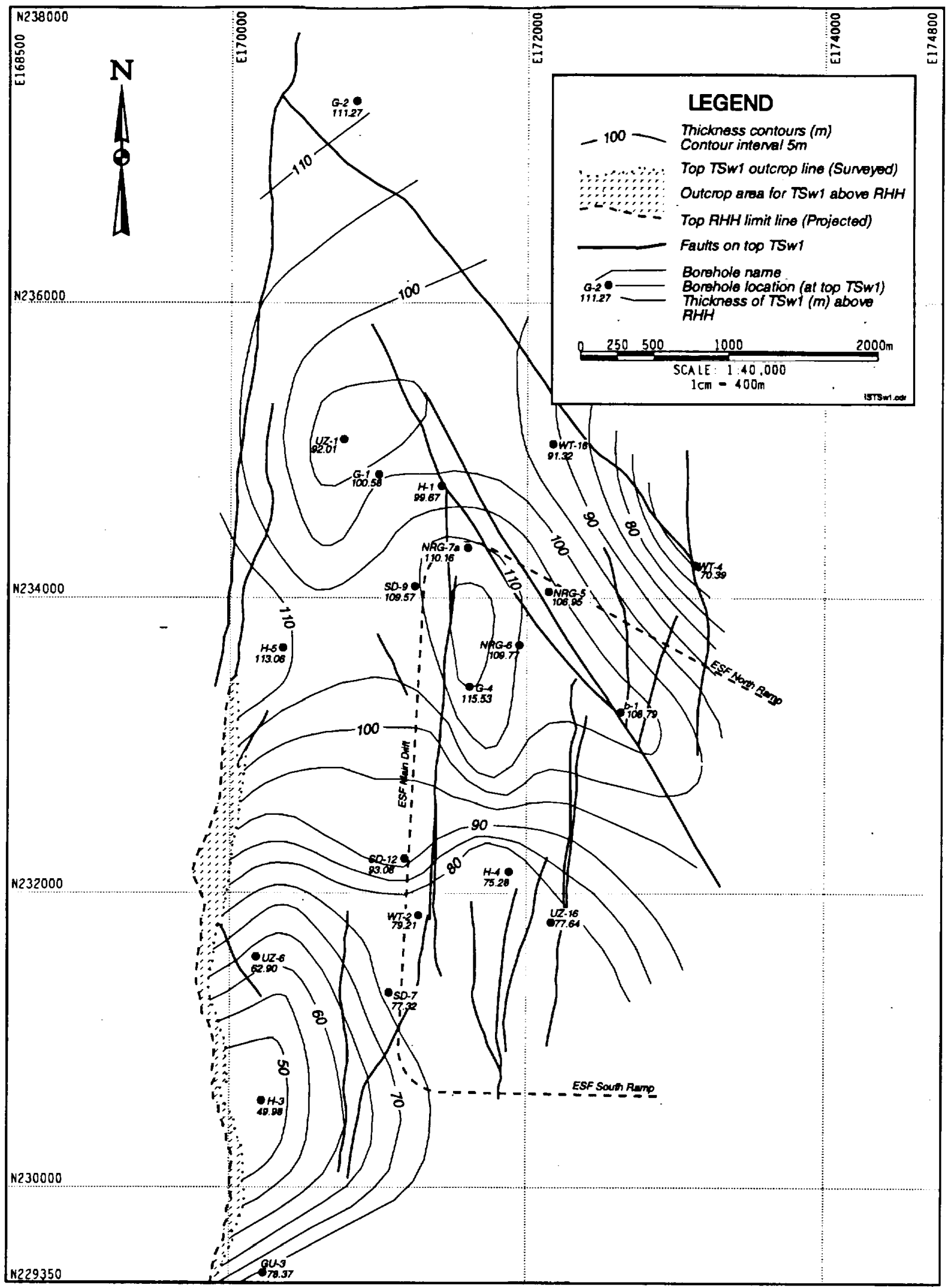

Figure 7. Thickness contours for part of TSw1 unit above the Repository Host Horizon (RHH). 
Title: Determination of Available Volume for Repository Siting

Document Identifier: BCA000000-01717-0200-00007, Rev. 00

Page: 41 of 81

Table 4. Statistics for estimates of lithophysal cavities for $3.05-\mathrm{m}(10-\mathrm{ft})$ lengths of core from borehole SD-9. Based on analysis of data presented in Reference 5.29. Values identified as $<1$ percent were assumed to be 0.5 percent.

\begin{tabular}{|c|c|c|c|c|c|c|}
\hline & \multirow{2}{*}{$\begin{array}{l}\text { T/M } \\
\text { Unit }\end{array}$} & \multirow{2}{*}{$\begin{array}{c}\text { Litho- } \\
\text { stratigraphic } \\
\text { Unit }\end{array}$} & \multirow{2}{*}{$\begin{array}{l}\text { Average } \\
\text { Percent } \\
\text { Cavities }\end{array}$} & \multirow{2}{*}{$\begin{array}{l}\text { Standard } \\
\text { Deviation }\end{array}$} & \multicolumn{2}{|c|}{ Range (\%) } \\
\hline & & & & & Min. & Max. \\
\hline & \multirow{2}{*}{ TSw1 } & Tptpulu & $6.3^{\circ}$ & 4.0 & 0 & 13 \\
\hline \multirow{4}{*}{$\begin{array}{l}\text { Rep. } \\
\text { Host } \\
\text { Hzn. } \\
\text { (RHH) }\end{array}$} & & Tptpull & 1.7 & 0.7 & 1 & 3 \\
\hline & \multirow{3}{*}{ TSw2 } & Tptpmn & 1.1 & 0.3 & $0.5(<1)$ & 2 \\
\hline & & Tptpll & 1.3 & 0.9 & 0 & 5 \\
\hline & & Tptpln & $0.5(<1)$ & 0.0 & $0.5(<1)$ & $0.5(<1)$ \\
\hline
\end{tabular}

Table 5. Statistics for apparent bulk density from bulk density log for borehole SD-9 (based on $0.61-\mathrm{m}$ (2-ft) sampling of digital log data from Reference 5.52).

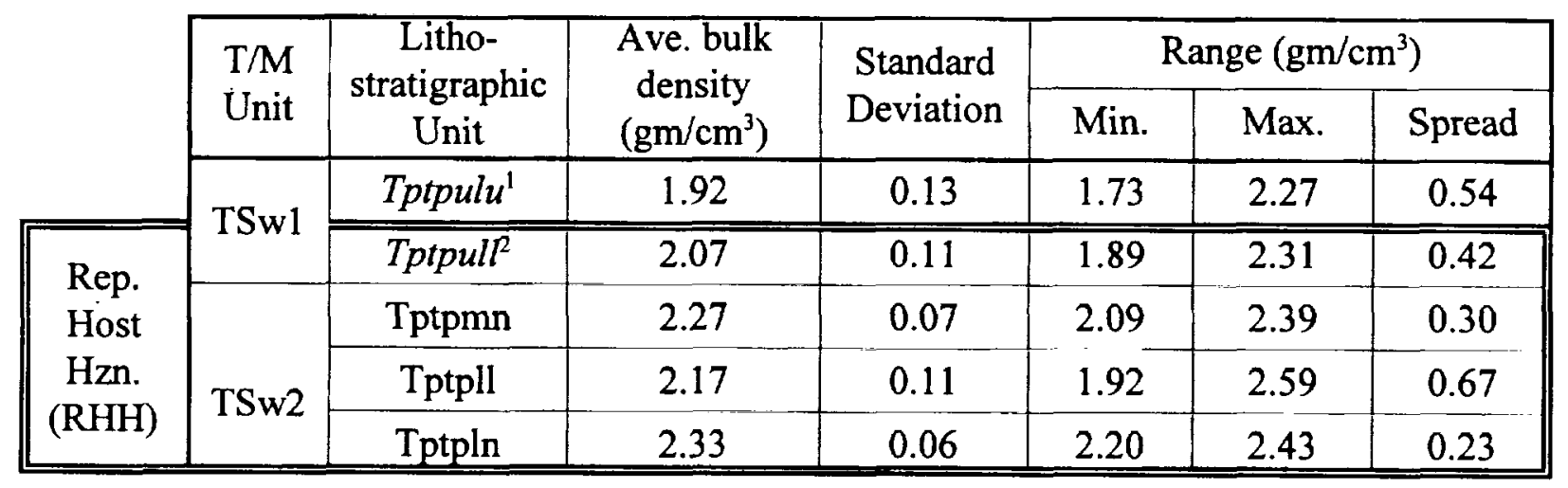

'Informal upper part of upper lithophysal zone.

${ }^{2}$ Informal lower part of upper lithophysal zone.

namely higher density welded tuff matrix with interspersed voids that locally lowers the bulk density of the rock mass.

This relationship between cavity, or porosity, and bulk density can best be illustrated by the use of a cross-plot developed for epithermal neutron porosity vs. bulk density (Figure 8). The epithermal neutron porosity data used in this illustration is non-qualified as a porosity value because the Schlumberger logging tool is calibrated to limestone porosity units and a conversion to volcanic tuffs has not been developed. When the epithermal neutron porosity log data (NEU, Reference 5.52) is 


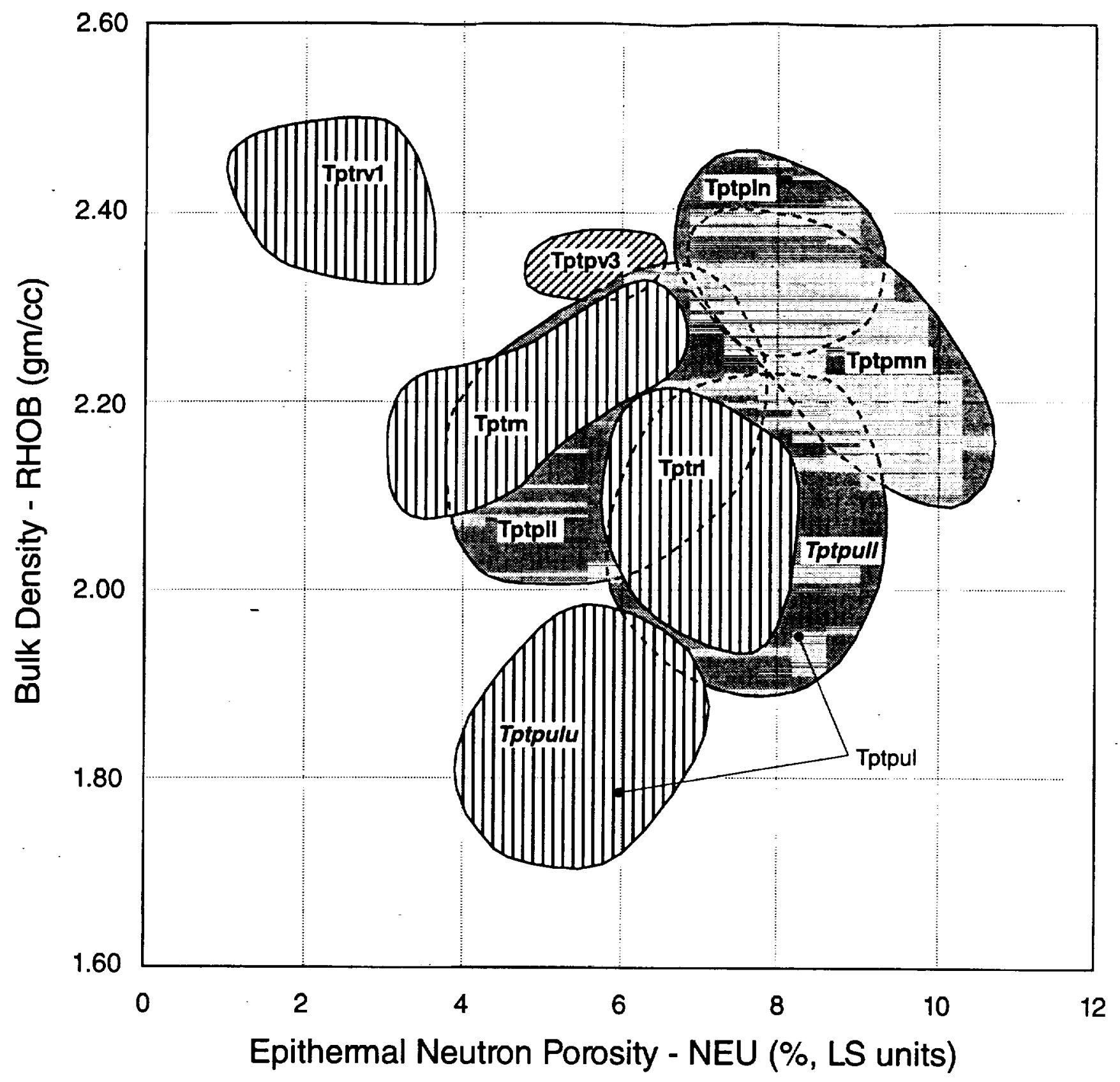

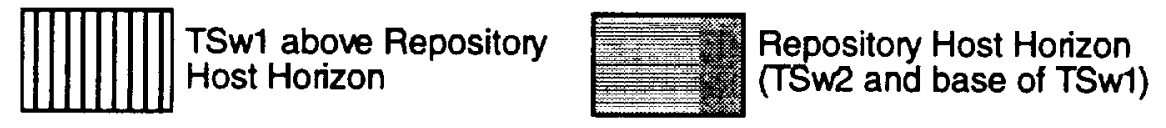

Tptry1 - densely-welded subzone, (vitrophyre)

Tptm - nonlithophysal zone

Tptpul (Tptpulu) - upper lithophysal zone, upper part
Tptpul (Tptpull) - upper lithophysal zone, lower part

Tptpmn - middle nonlithophysal zone

Tptpll - lower lithophysal zone

Tptpln - lower nonlithophysal zone

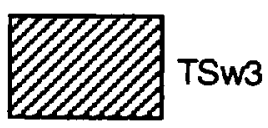

Tptpv3 - densely-welded subzone, (vitrophyre)

Figure 8. Borehole SD-9 geophysical log epithermal neutron-porosity / bulk density cross plot. 
plotted against the bulk density data (RHOB, Reference 5.52), data from different lithostratigraphic zones plot in predictable areas of the cross-plot. The vitrophyre cap rock (Tptrv1) plots as a very dense, low porosity rock (Figure 8 and Table 6). The nonlithophysal zone (Tptrn) plots in the mid range near the crystal-rich lithophysal zone (Tptrl), but has higher density and lower porosity than the lithophysal zone. The upper part of the lower lithophysal zone (Tptpulu) has the lowest bulk density of all the zones in the Topopah Spring Tuff welded rocks, reflecting the extensive lithophysal cavity development.

Table 6. General ranges of epithermal neutron porosity (\%, Limestone units) and bulk density values for units identified in borehole SD-9 and shown in the cross plot in Figure 8.

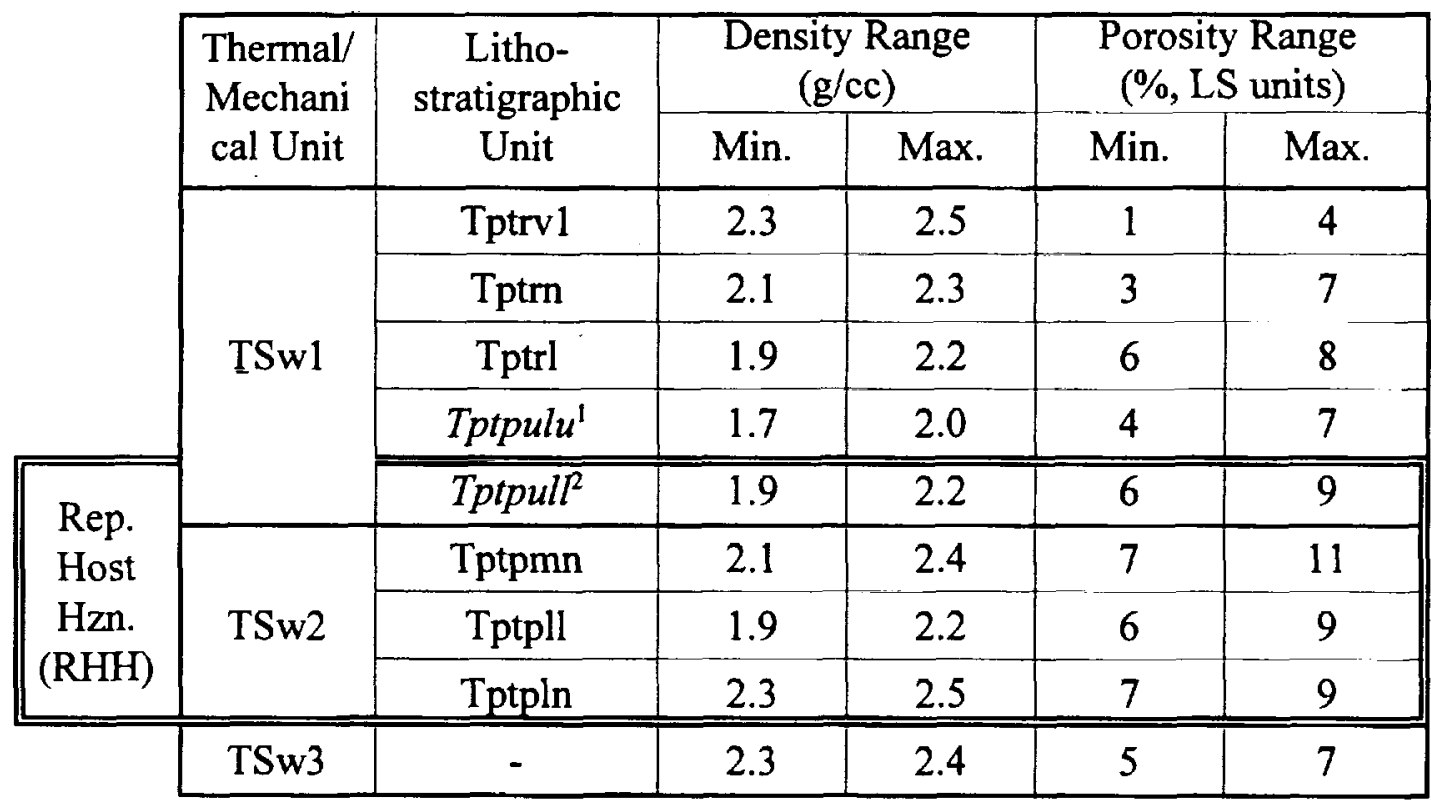

${ }^{1}$ Informal upper part of upper lithophysal zone.

${ }^{2}$ Informal lower part of upper lithophysal zone.

\subsubsection{Description of RHH}

The RHH includes the entire TSw2 unit and the lower part of the TSw1 unit, informally referred to herein as Tptpull. It overlies the basal TSw3 vitrophyre unit of the Topopah Spring Tuff. As identified by Ortiz and others (Reference 5.17), the TSw2 unit, which is equivalent to the RHH as defined in this design analysis, is generally lithophysae-poor. However, it does contain considerable lithophysae in the section. In relation to the overlying part of the TSwl unit above the RHH, however, it is relatively poor in lithophysal cavity development. In borehole SD-9, 61 percent of the RHH is identified as containing lithophysae, but the average cavity content is less than 2 percent. The RHH is thickest in the central part of the area, where it is over $230 \mathrm{~m}$ thick at boreholes H-1 and NRG-7a (Figure 9), and thins outward to 140 to $160 \mathrm{~m}$ along the edge of the area. The pattern of the RHH thickness contours suggest infilling of a general north-trending drainage basin. The upper part of the RHH outcrops along the southem part of Solitario Canyon and is in fault contact along 
Title: Determination of Available Volume for Repository Siting Document Identifier: BCA000000-01717-0200-00007, Rev. 00

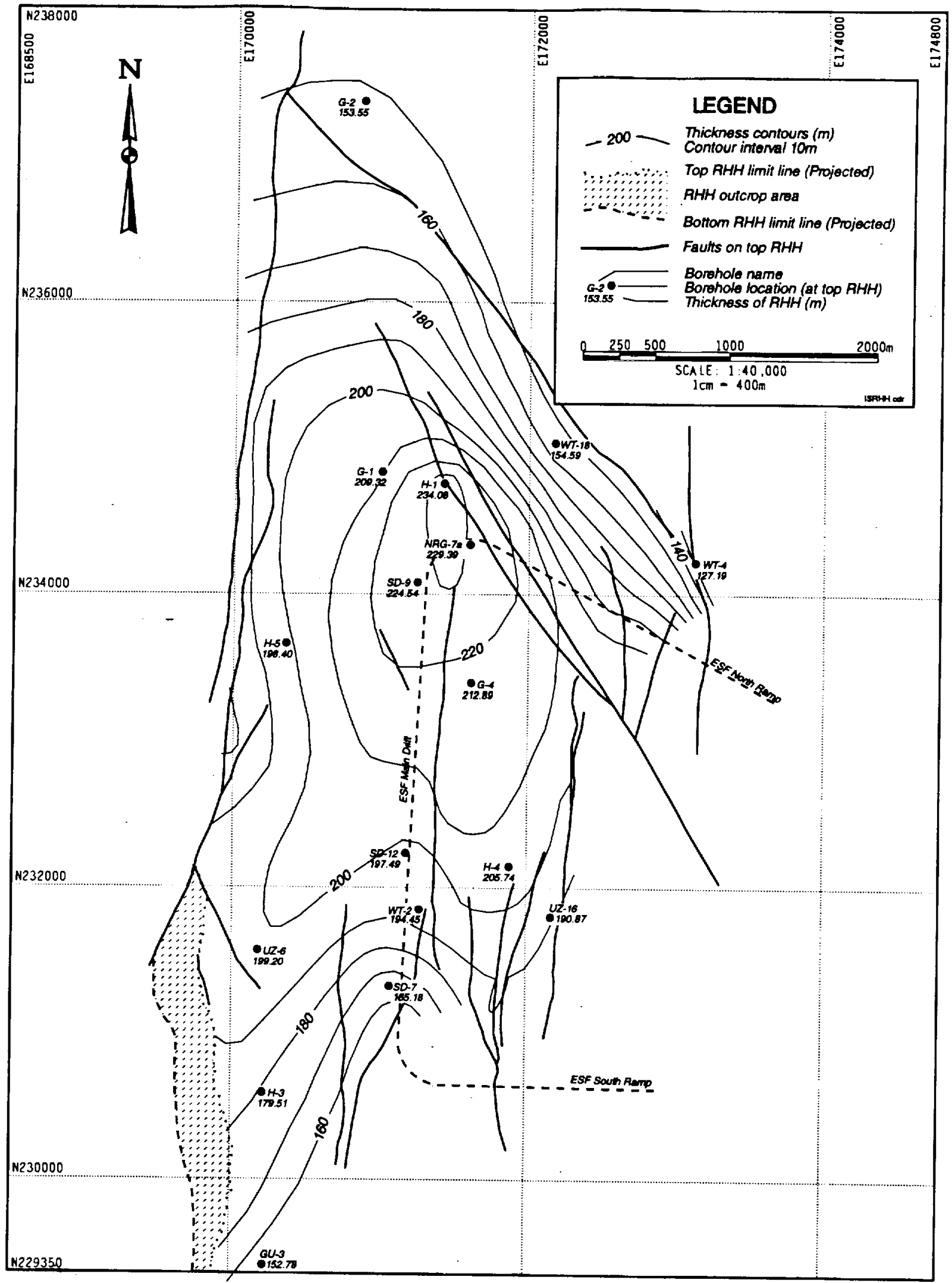

Figure 9. Thickness contours for RHH. 
the remainder of Solitario Canyon. The lower contact is in fault contact along the length of Solitario Canyon.

The lower part of the upper lithophysal zone, which is informally referred to as Tptpull (Figure 5) and lies between the top of the TSw2 unit and the top of the RHH, ranges from over $45 \mathrm{~m}$ in the north, and thins gradually to less than $10 \mathrm{~m}$ in the southeast (Figure 10). Underlying the informal Tptpull zone is the middle nonlithophysal zone (Tptpmn, Figure 5). This zone has a fairly consistent thickness of about 30 to $35 \mathrm{~m}$ in the repository area, but thins rapidly to less than $10 \mathrm{~m}$ towards the northeast and northwest, and thickens to over $50 \mathrm{~m}$ in the south (Figure 11). The underlying lower lithophysal zone (Tptpll, Figure 5), is the thickest zone within the RHH. It has a maximum thickness of about $130 \mathrm{~m}$ at borehole $\mathrm{H}-1$ and maintains a thickness of over $90 \mathrm{~m}$ throughout the northern half of the repository area (Figure 12). To the north, the zone thins rapidly to less than $50 \mathrm{~m}$ and to the south it thins gently to less than $50 \mathrm{~m}$. The lowest zone in the RHH is the lower nonlithophysal zone (Tptpln, Figure 5). It reaches its greatest thickness of over $70 \mathrm{~m}$ in the vicinity of borehole SD-12 and thins outward to less than $20 \mathrm{~m}$ in the north, less than $50 \mathrm{~m}$ in the northeast, and less than $50 \mathrm{~m}$ in the south (Figure 13).

Althought the RHH is defined as a lithophysae-poor unit, there is still considerable lithophysae development within its bounds, but not to the extent of development in the overlying TSwl unit. Generally, the lithophysae are confined to two zones, the informal lower part of the upper lithophysal zone (Tptpull) and 'the lower lithophysal zone (Tptpll). These are separated by the middle nonlithophysal zone (Tptpmn), shown in Figure 5, and the lower lithophysal zone is underlain by the lower nonlithophysal zone (Tptpln).

The upper-most zone of the RHH is the lower part of the upper lithophysal zone, informally referred to as Tptpull. As discussed in Section 7.3.2 of this design analysis, the upper contact is characterized by a dramatic change in the lithophysal cavity content and a characteristic bulk density log signature. Statistical analysis of the cavity estimate data shows a decrease from an average of 6.3 percent in the lithophysal zone of the overlying TSwl unit to 1.7 percent in the lithophysal zone at the top of the RHH (Table 4). The cavities range from 1 to 3 percent for the same zone in the RHH, whereas in the same zone of the TSwl they range up to 13 percent. This dramatic decrease is well-shown in the histogram of the estimated cavities (Figure 6). The bulk density log (Figure 6), shows a corresponding increase in density from about $1.9 \mathrm{gm} / \mathrm{cm}^{3}$ in the TSwl unit to about $2.0 \mathrm{gm} / \mathrm{cm}^{3}$ at the top of the RHH. Statistical analysis of the bulk density log data shows an average of $1.92 \mathrm{gm} / \mathrm{cc}$ for the upper part of the upper lithophysal zone and $2.07 \mathrm{gm} / \mathrm{cm}^{3}$ for the lower part of the upper lithophysal zone (Table 4). The spread of the range of density values is lower in the RHH portion (0.42) of the upper lithophysal zone than the TSwl portion $\left(0.54 \mathrm{gm} / \mathrm{cm}^{3}\right)$.

The middle nonlithophysal zone (Tptpmn) underlies the upper lithophysal zone and is in gradational contact with it. Typically, the gradation in properties occur over a vertical distance of several meters. Because of the reduced lithophysal cavity content, the middle nonlithophysal zone shows a significant increase in the bulk density $\log$ (Figure 6) to an average of $2.27 \mathrm{gm} / \mathrm{cm}^{3}$ (Table 5). The spread of the range also decreases significantly to $0.30 \mathrm{gm} / \mathrm{cm}^{3}$. The lithophysal cavity content of the middle nonlithophysal zone averages 1.1 percent, but ranges up to 2 percent (Table 4). Through most of the middle nonlithophysal zone, the lithophysal cavities are 1 percent or less except in the central part of the zone where there is commonly a thin occurance of lithophysal rocks. This is shown as the small spike on the histogram in Figure 6. 


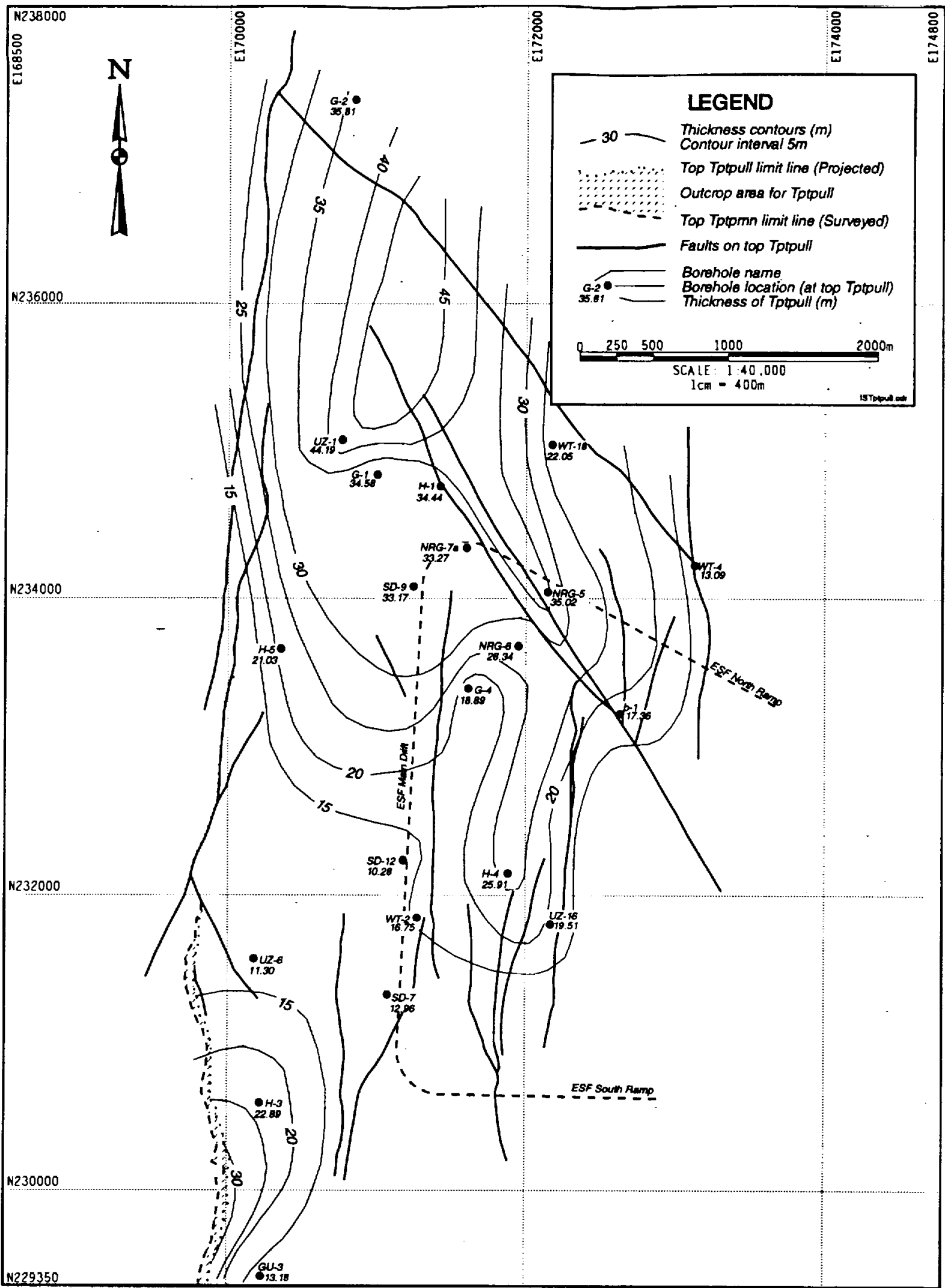

Figure 10. Thickness contours for informal lower part (Tptpull) of upper lithophysal zone (Tptpul). 


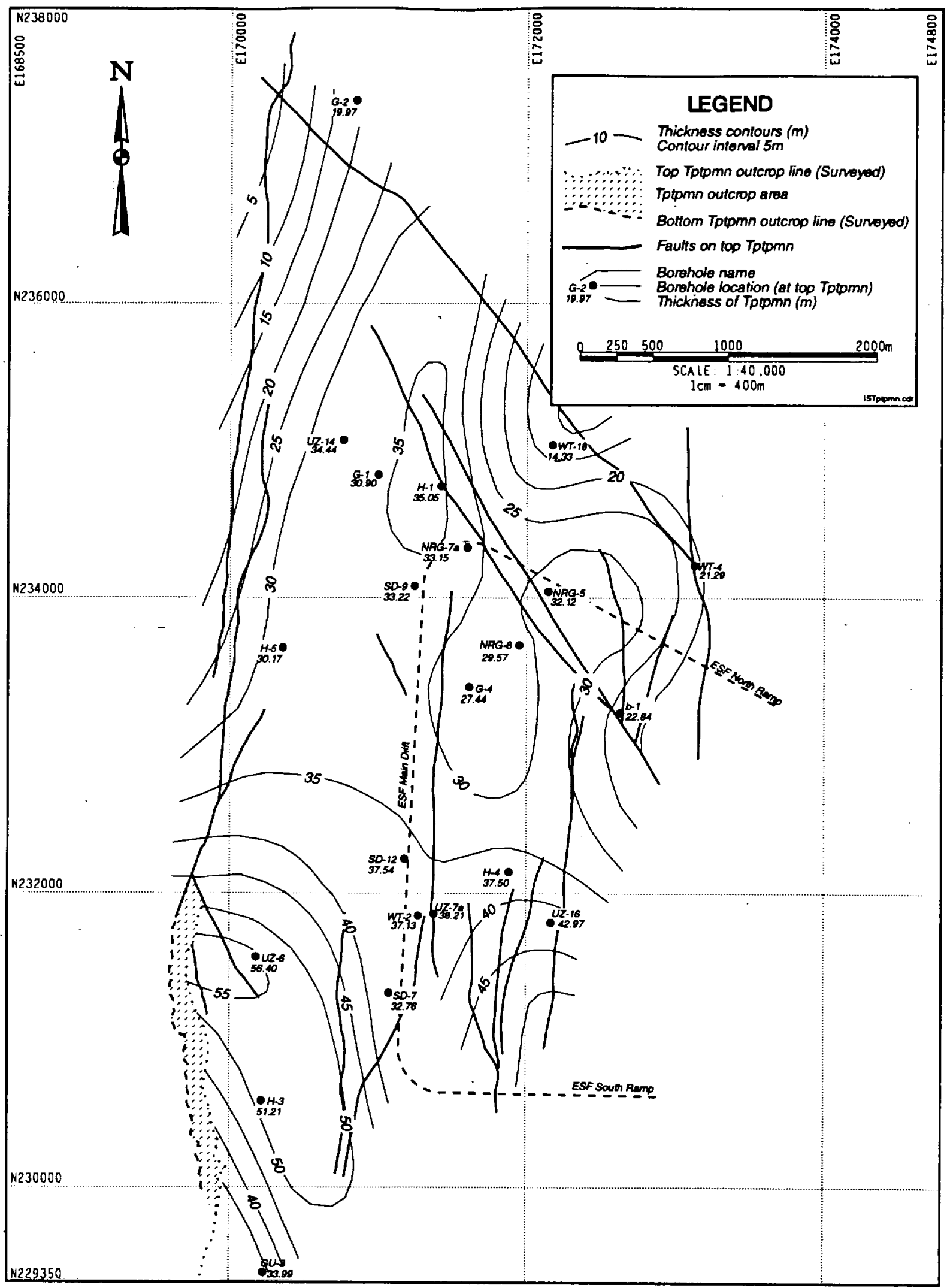

Figure 11. Thickness contours for middle nonlithophysal zone (Tptpmn). 
Title: Determination of Available Volume for Repository Siting Document Identifier: BCA000000-01717-0200-00007, Rev. 00

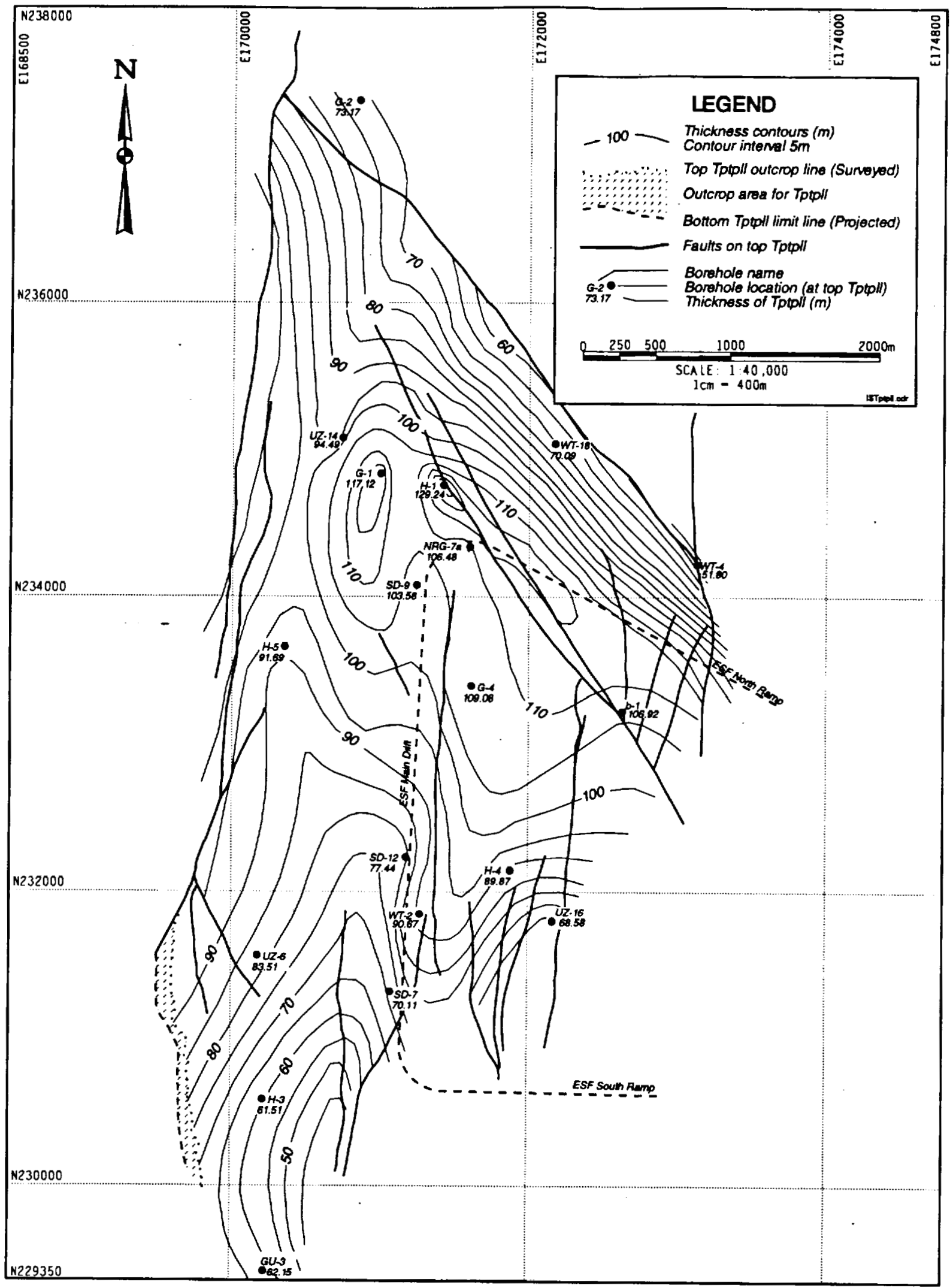

Figure 12. Thickness contours for lower lithophysal zone (TptpIl). 


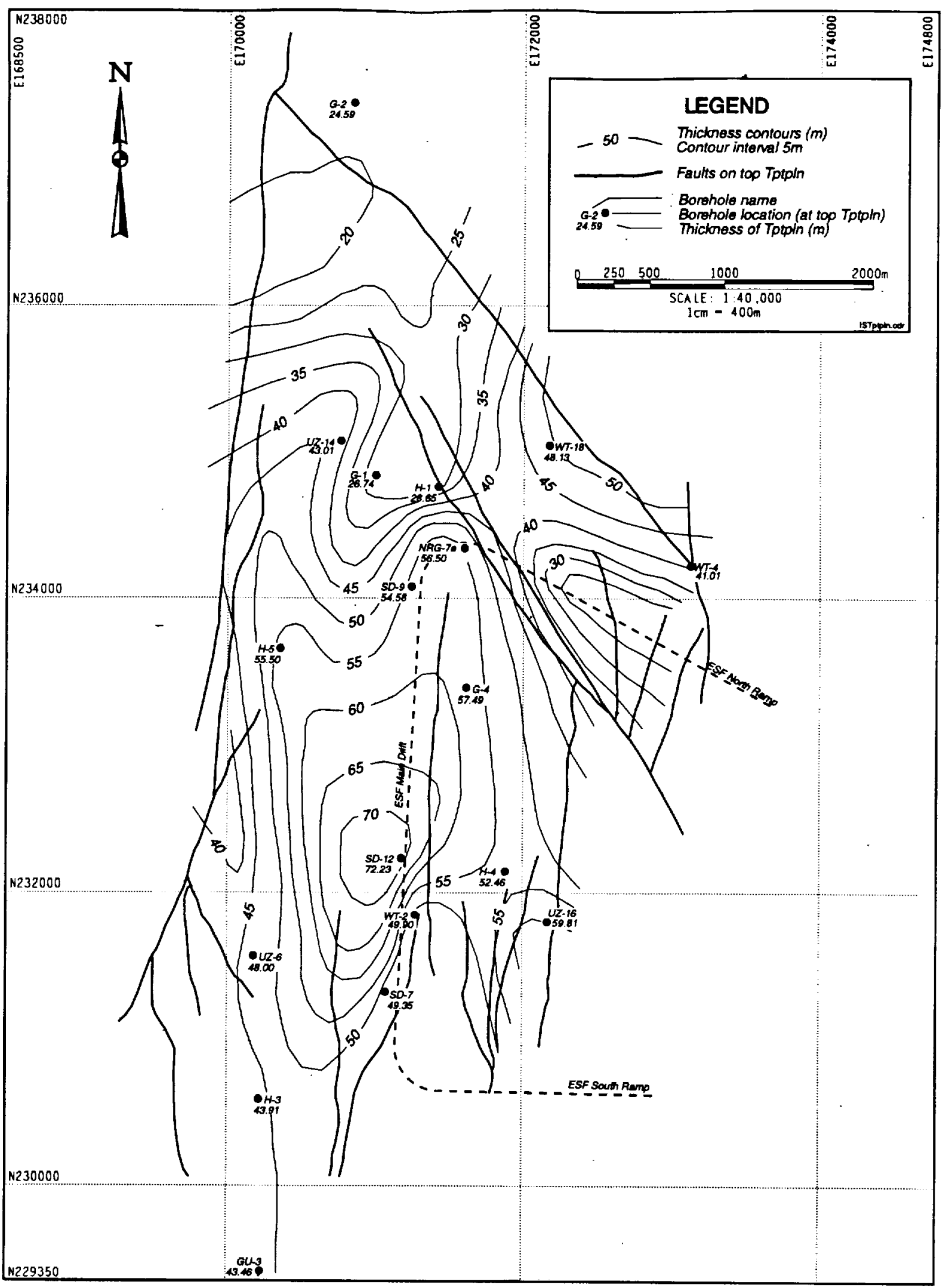

Figure 13. Thickness contours for lower nonlithophysal zone (Tptpln). 
The thickest zone in the RHH is the lower lithophysal zone (Tptpll). It is contrasted with the overlying middle nonlithophysal zone by a drop in bulk density and increased spikes in the bulk density $\log$ (Figure 6). The average density from the $\log$ is $2.17 \mathrm{gm} / \mathrm{cm}^{3}$, but the density ranges from 1.92 to $2.59 \mathrm{gm} / \mathrm{cm}^{3}$ (Table 5), with a spread of $0.67 \mathrm{gm} / \mathrm{cm}^{3}$. This suggests a rock containing well-developed lithophysal cavities that may be greater than that shown in the estimated cavity histogram (Table 4). The analysis of the lithophysal cavity estimates in this zone shows an average of 1.3 percent cavities, ranging from 0 to 5 percent. The higher cavity parts of the zone appear to lie within the central part of the zone (Figure 6).

The bottom zone of the RHH is the lower nonlithophysal zone (Tptpln). The contact between it and the overlying lower lithophysal zone is typically gradational like the lower lithophysal/middle nonlithophysal contact higher in the RHH. The bulk density log shows this gradation from the 2.17 $\mathrm{gm} / \mathrm{cm}^{3}$ density of the lower lithophysal to the $2.33 \mathrm{gm} / \mathrm{cm}^{3}$ density of the lower nonlithophysal zone (Figure 6). The spread of the range is low $\left(0.23 \mathrm{gm} / \mathrm{cm}^{3}\right)$ like the middle nonlithophysal zone (Table 5). The lithophysal cavity estimate shows consistently less than 1 percent cavities (Table 4), but the spiky nature of the bulk density log suggests the presence of cavities, although less than the overlying lower lithophysal zone.

The neutron porosity/density cross plot in Figure 8 shows the distribution of the individual zones within the RHH in relation to the other zones. The four zones of the RHH are centrally located in the plot between a density of 1.9 to $2.45 \mathrm{gm} / \mathrm{cm}^{3}$ and porosity of 4 to 11 percent. The ranges of each zone are listed in Table 6.

\subsubsection{Description of TSw3 Unit}

The underlying TSw3 unit, is composed of densely-welded vitrophyre (volcanic glass) and ranges in thickness from less than $5 \mathrm{~m}$ along the eastern edge of the area to over $35 \mathrm{~m}$ in the far south (Figure 14). A lobe of less than $10 \mathrm{~m}$ thickness stretches southwestward across the area from the northeast. More dramatic thickness changes occur in the south near borehole H-3. This unit does not outcrop in Solitario Canyon and is faulted along the Solitario Canyon fault.

The bulk density log from borehole SD-9 shows the typical signature of the TSw3 unit (Figure 6). Compared with the overlying lower nonlithophysal zone, the signature of the log in the vitrophyre is typically less spiked than the overlying nonlithophysal zone, and in borehole SD-9, the upper contact is where the spikes markedly decrease. In the neutron-porosity/bulk density cross plot, the TSw3 unit plots in a tight area above the RHH data points (Figure 8). The density ranges from 2.3 to $2.4 \mathrm{gm} / \mathrm{cm}^{3}$ and the porosity ranges from 5 to 7 percent (Table 6).

\subsection{STRUCTURES}

The geologic structures in the Yucca Mountain area are a result of large-scale plate tectonics as well as regional volcanic-related forces. These forces have acted on the tuff deposits since they were formed during the Miocene. Resulting structural features include the regional tilting of the strata and the more local-scale faults and joints. The fault structural fabric of the area is dominated by northstriking and northwest-striking faults. The central block, which is the structural block covered by the Design Model, contains several major fault sets, but for the most part, the repository site is a 
Title: Determination of Available Volume for Repository Siting

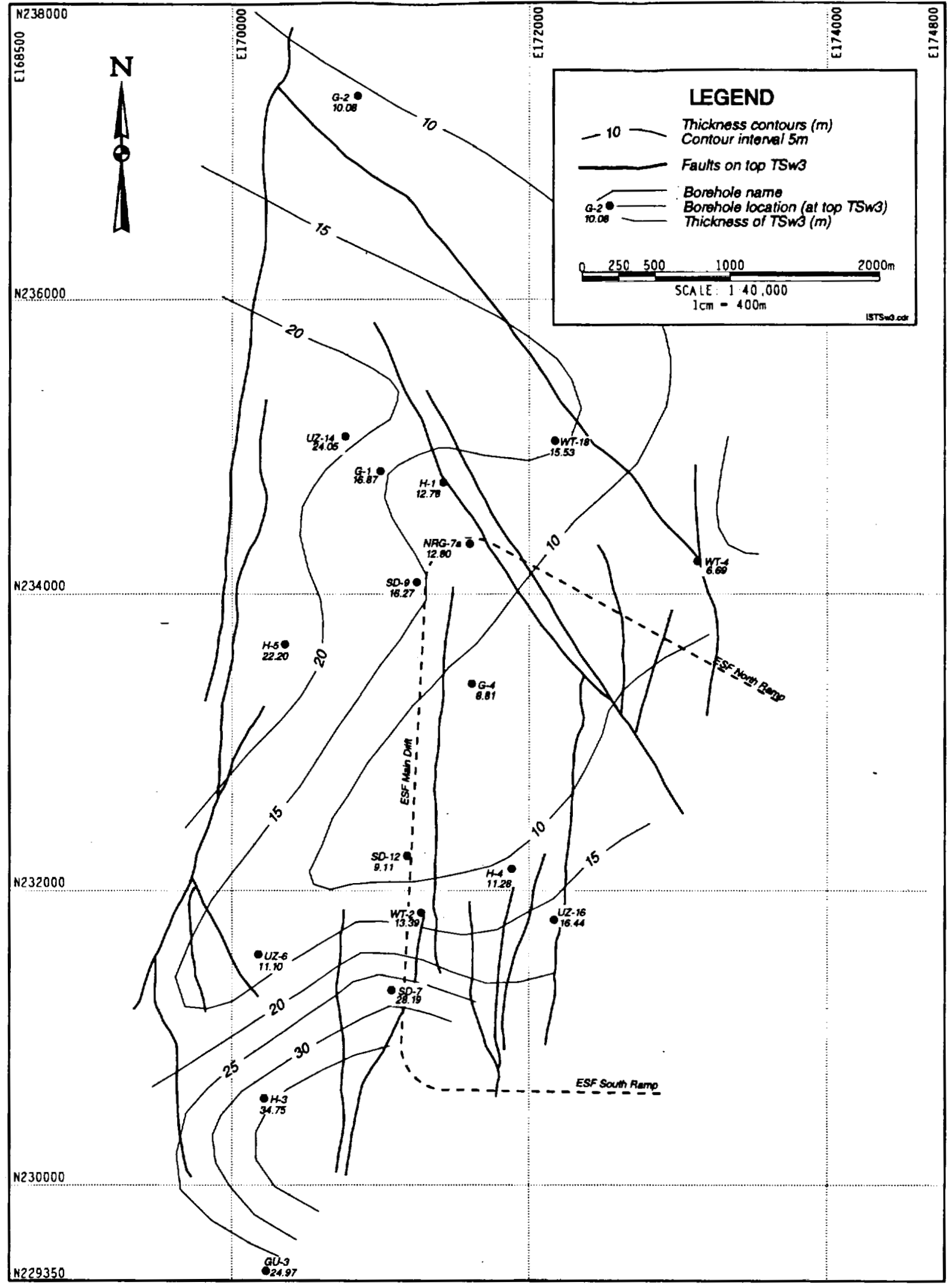

Figure 14. Thickness contours for TSw3 unit. 
contiguous block that is bounded by major faults but remains relatively fault free within. The fault information used in the modeling came from the recent surface mapping by Day and others (Reference 5.48), shown in Figure 15.

\subsubsection{North-Striking Faults}

The north-striking faults are the dominant fault pattern in the central block. Two of these faults form the eastern and western limits of the central block. These include the Bow Ridge fault on the east and the Solitario Canyon fault on the west (Figure 15). The Bow Ridge fault is a down-to-the-west normal fault of approximately $100 \mathrm{~m}$ displacement (Reference 5.48). Where the fault crosses the ESF, it is a $2-m$ wide zone that dips approximately 60 degrees to the west and contains fault gouge. To the west, there are associated with the Bow Ridge fault, a series of north-striking high-angle normal faults downthrown both to the west and east. These faults belong to the group referred to informally by Scott (Reference 5.24) as the "imbricate faults". Based on the most recent mapping (Reference 5.48), it is now believed that these faults formed as a result of hanging-wall deformation associated with the Bow Ridge fault. The eastern-most faults within this group are discontinuous, east-dipping, down-to-the-east normal faults that form graben structures with the associated downto-the-west Bow Ridge fault. Vertical displacement along these faults can be as much as $30 \mathrm{~m}$. The rock units within this structural zone dip steeply (20-30 degrees) to the east compared with the more gentle dip of the beds to the west.

The western boundary of the Design Model and the central structural block are defined by the Solitario Canyon fault. This fault has been identified as a "scissors" fault with considerable variation in displacement along its length. In the north, it is a steep, narrow zone with down-to-the-east displacement of about $70 \mathrm{~m}$ (Reference 5.48). Southward, it hinges where it crosses Tea Cup Wash, then continues south where it widens to an anastamosing zone of highly brecciated down-to-the-west faults with over $500 \mathrm{~m}$ of displacement. In places, the zone is as much as $550 \mathrm{~m}$ wide with the eastern edge exposed on the eastern slope of Solitario Canyon and the western edge lying beneath the Quatemary fill of the canyon floor. In the area of the central block, there are numerous splay faults extending out from the main fault zone eastward into the block (Figure 15). Evidence collected in the recent mapping indicates that the Solitario Canyon fault was active after the deposition of the Topopah Spring Tuff but prior to the deposition of the Tiva Canyon Tuff. Several of the fault splays exposed along Yucca Crest show decreasing displacement up-section and die out within the Tiva Canyon Tuff.

The Ghost Dance fault is a prominent throughgoing, north-striking fault within the central block. It consists of a zone of faults that are steeply west-dipping $\left(75^{\circ}-85^{\circ}\right)$ with down-to-the-west displacement (Reference 5.48). In the north, the fault is a relatively narrow zone $2-4 \mathrm{~m}$ wide with as much as $6 \mathrm{~m}$ of displacement. In the central area, the Ghost Dance fault widens to a zone about 100-150 m wide and is composed of several splays with intervening breccia. The cumulative offset within this zone is $15-20 \mathrm{~m}$. In the south, the zone is about $55 \mathrm{~m}$ wide and has $27 \mathrm{~m}$ of vertical offset. At Broken Limb Ridge (Figure 2), the fault bifurcates with the western splay merging with the Abandoned Wash fault and the eastern splay extending towards, but not joining, the Dune Wash fault.

The Abandoned Wash fault is in the far southern part of the area. The main fault trace merges northward with the western splay of the Ghost Dance fault. The Abandoned Wash fault also 


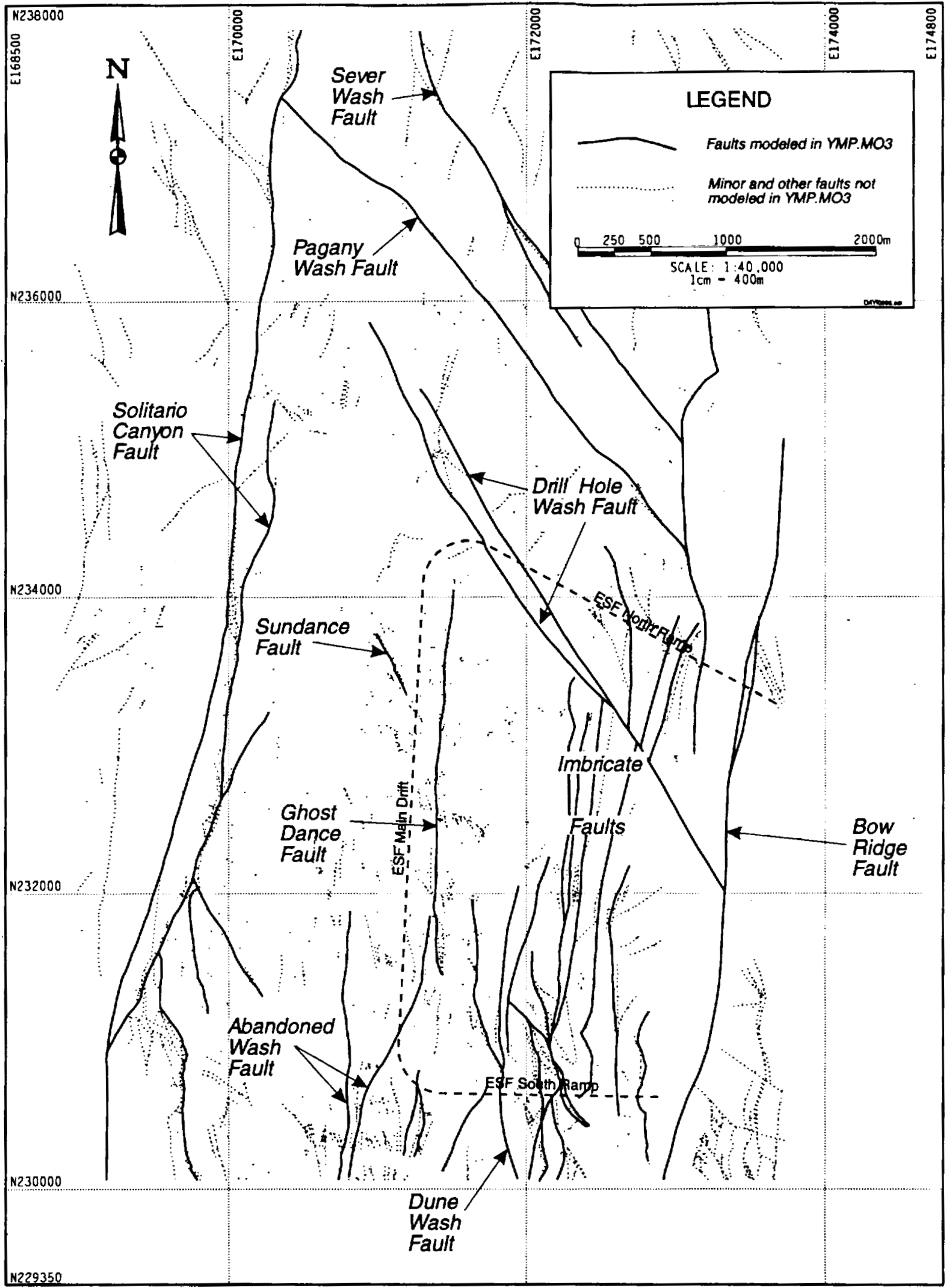

Figure 15. Surface faults in the Design Model area (Reference 5.48). 
bifurcates to the north with a splay trending northward into the southern part of the repository area. The Abandoned Wash fault is characterized by apparent small offsets and zones of breccia (Reference 5.48).

\subsubsection{Northwest-Striking Faults}

The northem part of the area is dominated by northwest-striking faults of which three are prominent. These faults include Sever Wash, Pagany Wash, and Drill Hole Wash faults. The latest movement on the Sever Wash and Pagany Wash faults was right-lateral strike-slip (Reference 5.48). The Pagany Wash fault forms the northern limit of the Design Model and for this design analysis is assumed to be a Type I fault (Section 4.3.8). It truncates to the northwest against the Solitario Canyon fault and possibly to the southeast against a north-striking fault associated with the Bow Ridge fault. In the northwestem part of the Pagany Wash fault, there is about $6 \mathrm{~m}$ of down-to-thesouthwest vertical separation, while in the southeastern part of it, there is about $10 \mathrm{~m}$ of down-to-thenortheast vertical separation (Reference 5.48).

Drill Hole Wash fault is believed to be a system of related faults that lie, for the most part, below the Quaternary alluvial deposits within Drill Hole Wash. The main trace of the fault is not exposed on the surface, but where the ESF crossed the fault, it appeared as two en echelon, near vertical, northwest-striking faults located at Stations 19+01 and 19+42 (Reference 5.44). These faults are downthrown to the west about $4 \mathrm{~m}$ and have horizontal slickensides with right-lateral offset. Where the southern splay of the fault is exposed on the surface at Tonsil Ridge (Figures 2 and 17), it strikes $\mathrm{N} 30^{\circ} \mathrm{W}$, dips $80-85^{\circ}$ to the southwest and has a cumulative vertical offset of about $15 \mathrm{~m}$ down-to-thesouthwest (Reference 5.48). Projecting this surface exposure to the ESF, it appears as a 1- to $2-\mathrm{m}$ wide uncemented breccia zone with an apparent vertical offset of $1.2 \mathrm{~m}$ down-to-the-southwest and striking $\mathrm{N} 10^{\circ} \mathrm{W}$ (Reference 5.48). In comparing the characteristics of the surface exposure with that encountered in the ESF, it can be seen that there is considerable variability in relative offset $(15 \mathrm{~m}$ vs. $1.2 \mathrm{~m}$ ) and orientation ( $\left(\mathrm{N} 30^{\circ} \mathrm{W}\right.$ vs. $\left.\mathrm{N} 10^{\circ} \mathrm{W}\right)$ between the surface and subsurface. This is similar to other fault variability observed throughout the central block (Reference 5.48).

A minor fault zone in the central block that was first recognized by Spengler and others (Reference 5.33) was named the Sundance fault zone. The zone is about $750 \mathrm{~m}$ long and has a cumulative down-to-the-northeast displacement of 6-11 m. They suggested that the Sundance fault offset the Ghost Dance fault, and was therefore younger than the north-striking fault. Later mapping, however, has shown that the Sundance fault does not offset the Ghost Dance fault, but terminates to the west of it (Reference 5.21).

\subsubsection{Fractures}

Fractures found in the rocks at Yucca Mountain were formed as a result of both cooling of the rock mass and post-cooling tectonic forces. Rock characteristics are believed to have influenced the nature of fracturing, as observed in the ESF tunnel mapping (Reference 5.44). Highly welded tuff and vitrophyre are more brittle, thus fracture more readily, whereas the nonwelded or moderately welded tuffs have fewer fractures of generally shorter lengths because they are less brittle. As to be expected, tectonic fracturing increases near major faults.

Fracture cluster analysis of the data from the ESF tunnel mapping shows three structural sets from 
Station $4+00$ to $21+87$ (Reference 5.44 ). The first set strikes about $\mathrm{N} 74-78^{\circ} \mathrm{E}$ and dips $88^{\circ} \mathrm{W}$. These fractures have been identified as cooling joints that occur primarily in the Tiva Canyon and Topopah Spring Tuffs. The second set strikes about $\mathrm{N} 35-39^{\circ} \mathrm{E}$ and dips $81-82^{\circ} \mathrm{W}$ and represents the dominant tectonic fracture pattern. The third set is comprised of shallow dipping, subhorizontal fractures or vapor-phase partings that occur mostly in the Tiva Canyon and Topopah Spring Tuffs. These fractures strike about $\mathrm{N} 16-25^{\circ} \mathrm{E}$ and $\operatorname{dip} 15-50^{\circ}$. These three fracture sets are less well defined through the curve from Station $21+87$ to $28+00$ where the tunnel orientation changes to that of the main drift. Since the orientation of the tunnel changes, the natural bias in the detailed line mapping data changes, resulting in some fracture sets becoming less well represented, while others are better represented. Although the summary report of the ESF main drift was not released in time for data on fractures to be analyzed and included herein, the general dominant fracture trend in the ESF main drift tunnel strikes about $\mathrm{N} 45-69^{\circ} \mathrm{W}$ and is nearly vertical (Reference 5.62). These joints are typically long, smooth and planar. Locally, fracture densities may be greater than 12 per meter. These fractures are confined to the middle nonlithophysal zone (Tptpmn) and are identified as cooling joints.

\subsubsection{Strata Tilt}

The dip of the strata at the surface in the Yucca Mountain area is generally about 6 degrees to the east (Figure 16), but at depth the dip changes to reflect thickness and depositional trends (Figure 22). As discussed in the Stratigraphy Modeling section of this design analysis (Section 7.1.5), the contact surfaces near the top of the Topopah Spring Tuff would be expected to have been nearly level at the time of deposition. Deeper in the section, the contact surfaces would reflect the irregularity of the unconformity at the base of the tuff unit. The strata tilt, even though it has been modified by later regional tilt, reflects this increased complexity with increasing depth. The structure maps for the top of TSw1, RHH, TSw3, and CHn are shown in Figures 16, 17, 21, and 22, respectively. The structure maps for the top of the lithostratigraphic zones within the RHH are shown in Figures 18 for the middle nonlithophysal zone (top TSw2), Figure 19 for the lower lithophysal zone, and Figure 20 for the lower nonlithophysal zone. At the top of the TSw1 level (Figure 16), the strata strike generally north-south in the southern and central parts of the repository area and dips at about $6^{\circ}$ to $9^{\circ}$ to the east; however, in the northern part near Drill Hole Wash fault, it rotates eastward to strike about N20 E and dips about $5^{\circ}$ to $6^{\circ}$ to the southeast. Progressing downward in the section (Figures 17,18 , and 19), the southern part maintains nearly the same attitude (north-south), but the central part rotates westward to about $\mathrm{N}^{\circ} 5^{\circ} \mathrm{W}$ and maintains about the same dip. North of Drill Hole Wash fault, it maintains the same general $\mathrm{N} 20^{\circ} \mathrm{E}$ strike. This part of the section contains most of the repository level. Near the bottom of the Topopah Spring Tuff (Figures 20,21, and 22), the beds in the area of Drill Hole Wash fault rotates around to about $N 50^{\circ} \mathrm{E}$ to form a syncline with its axis near the Drill Hole Wash fault. 


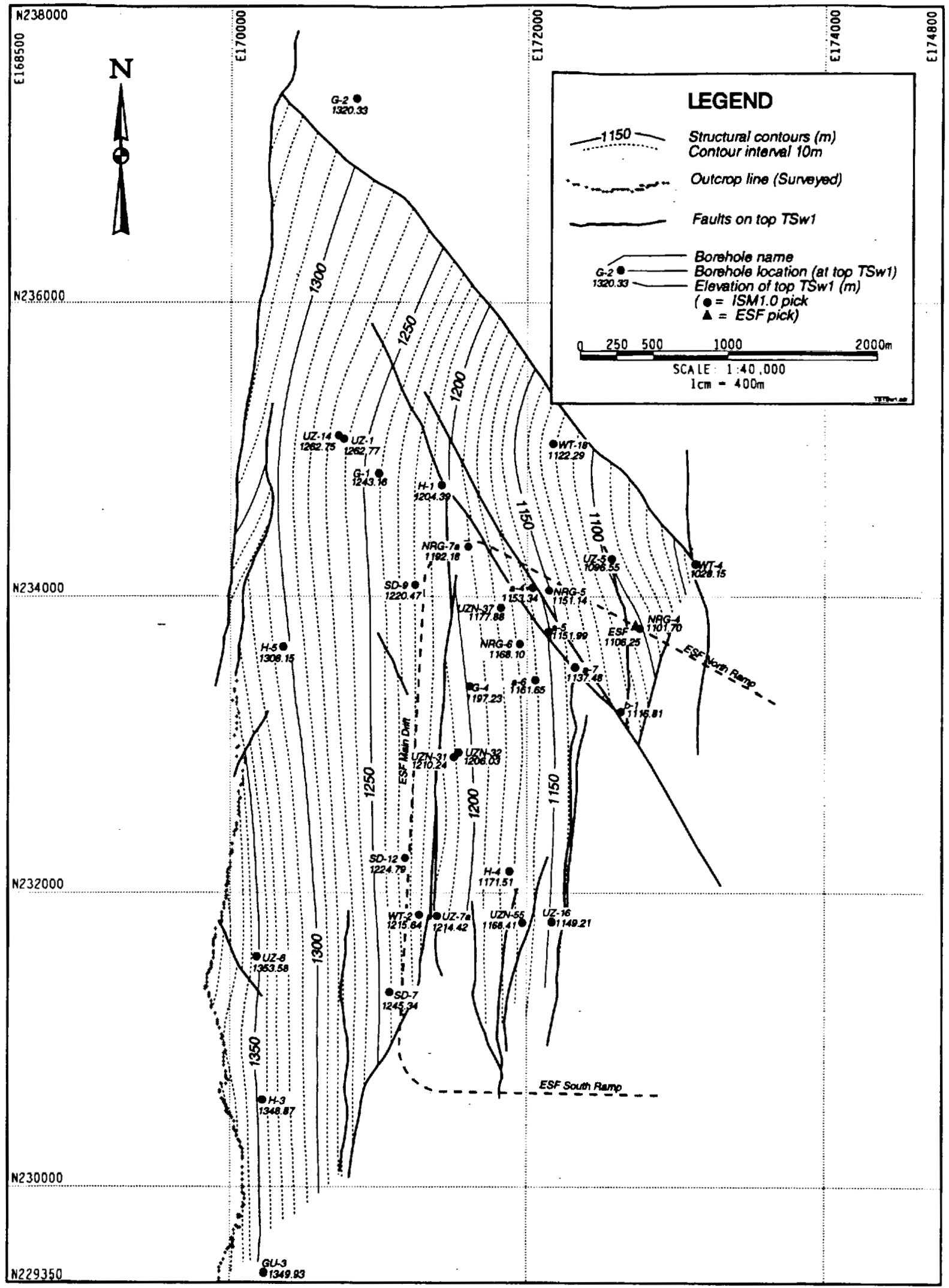

Figure 16. TSw1 unit top surface elevation contours. 


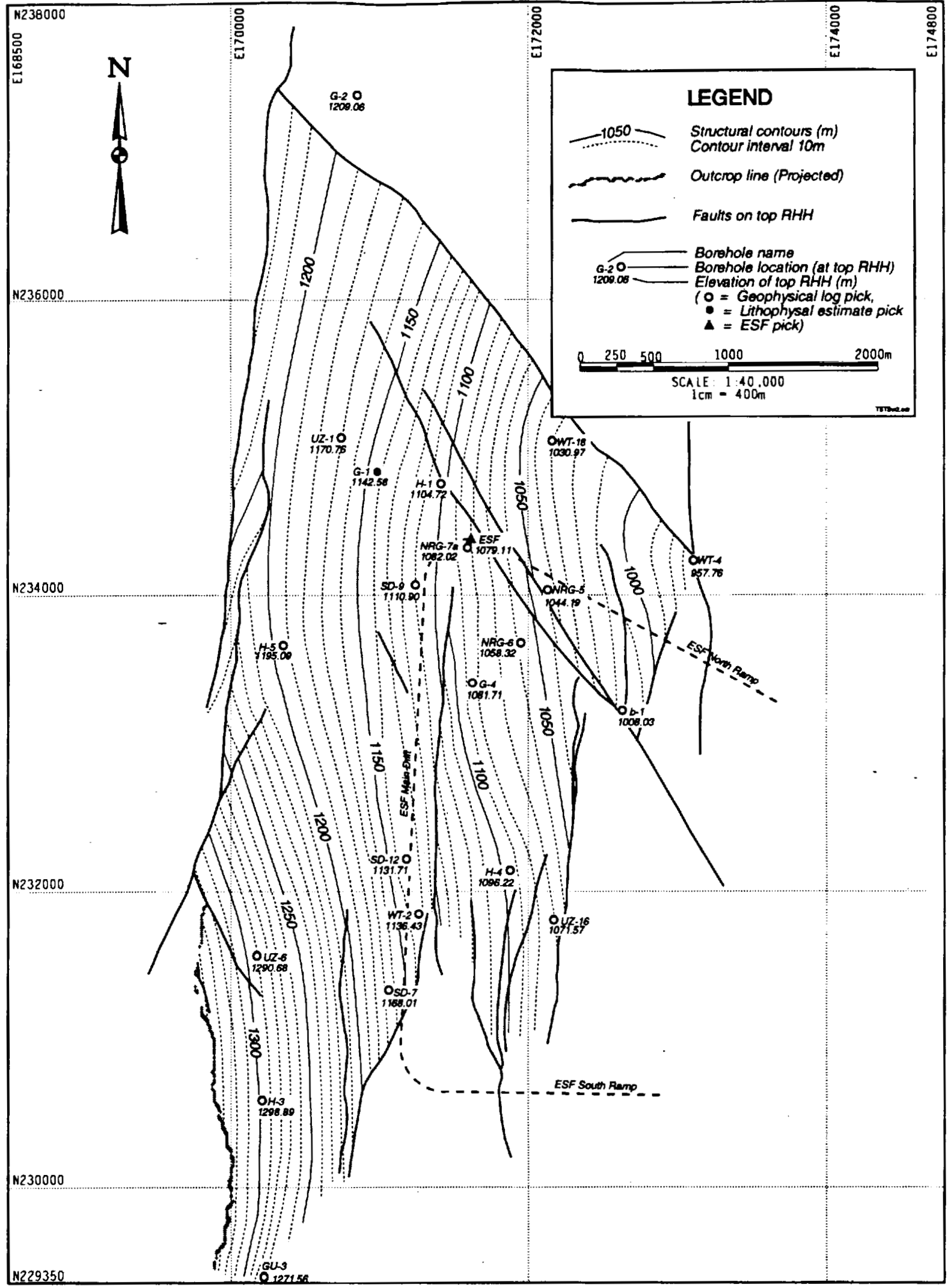

Figure 17. $\mathrm{RHH}$ top surface elevation contours. 


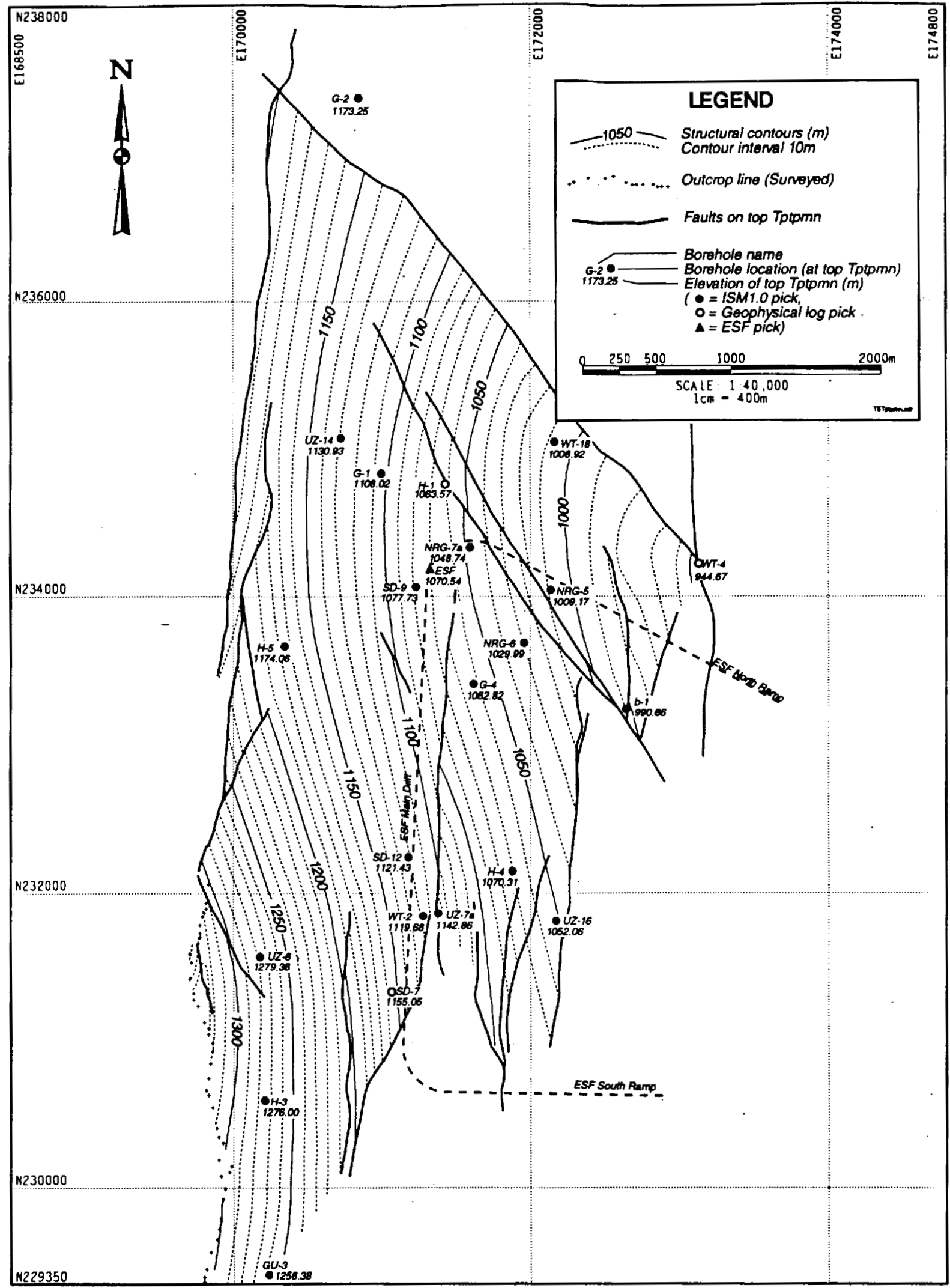

Figure 18. Middle nonlithophysal zone (Tptpmn) top surface elevation contours. 
Title: Determination of Available Volume for Repository Siting

Document Identifier: BCA000000-01717-0200-00007, Rev. 00

Page: 59 of 81

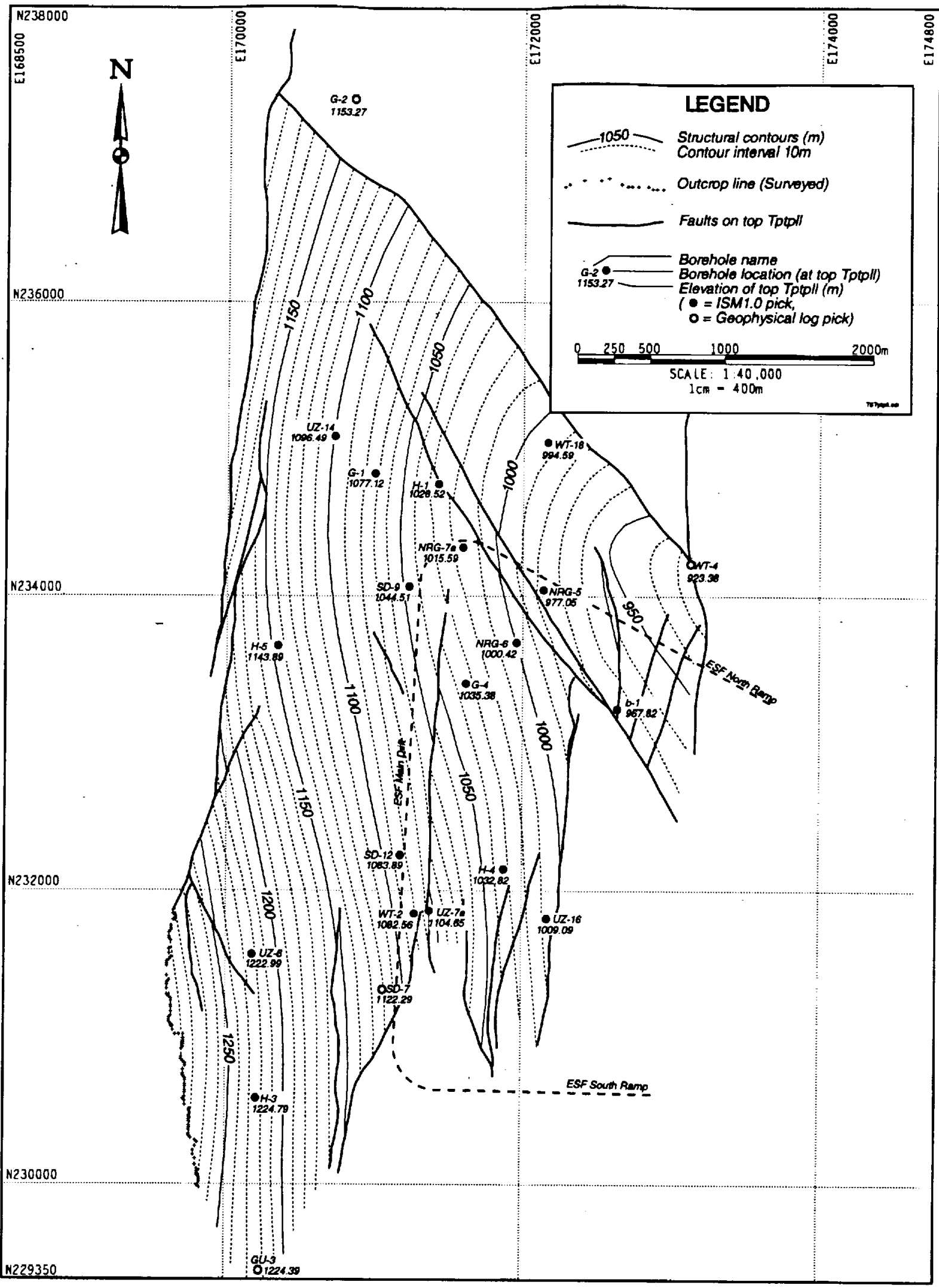

Figure 19. Lower lithophysal zone (Tptpll) top surface elevation contours. 


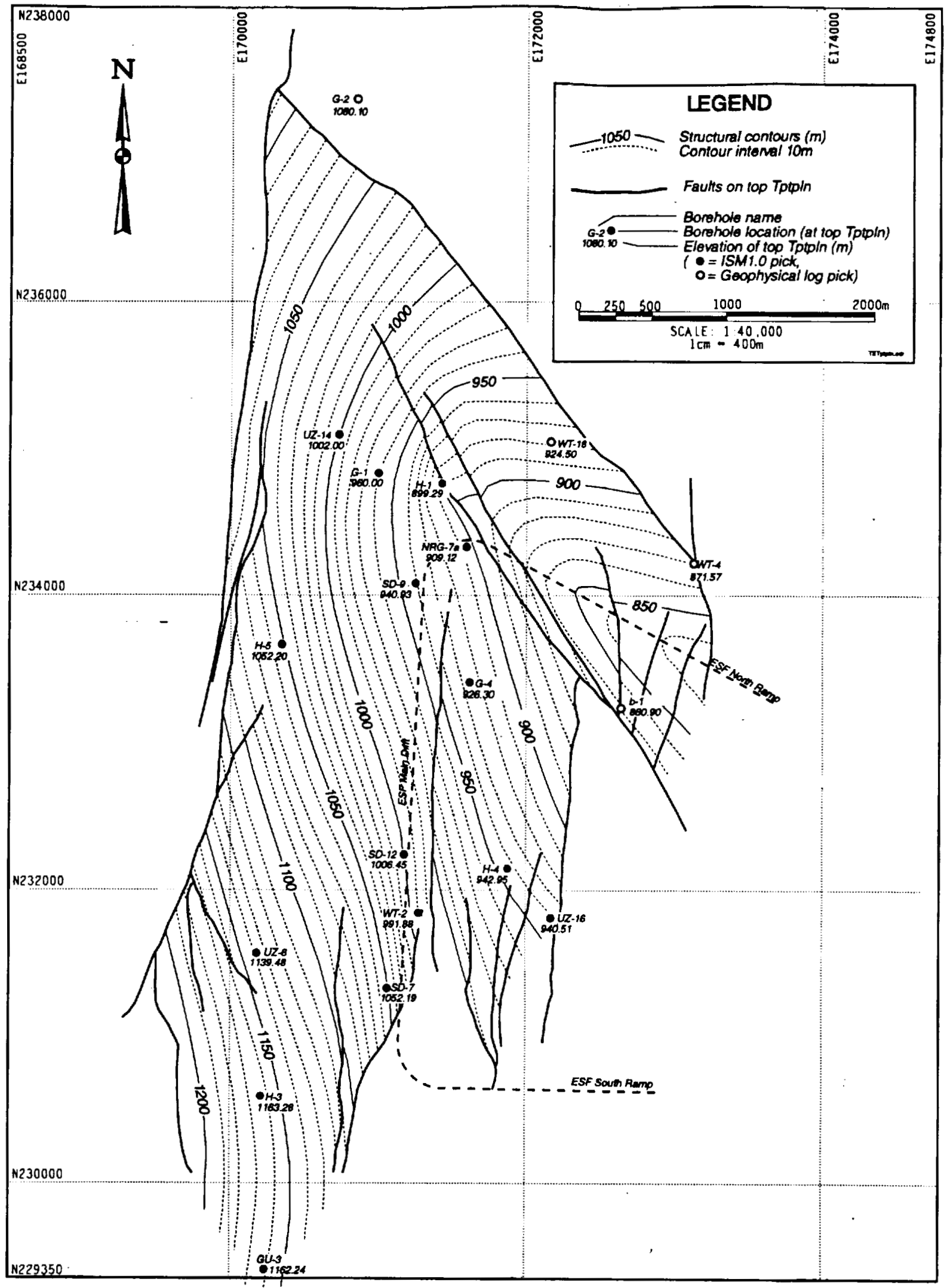

Figure 20. Lower nonlithophysal zone (Tptpln) top surface elevation contours. 


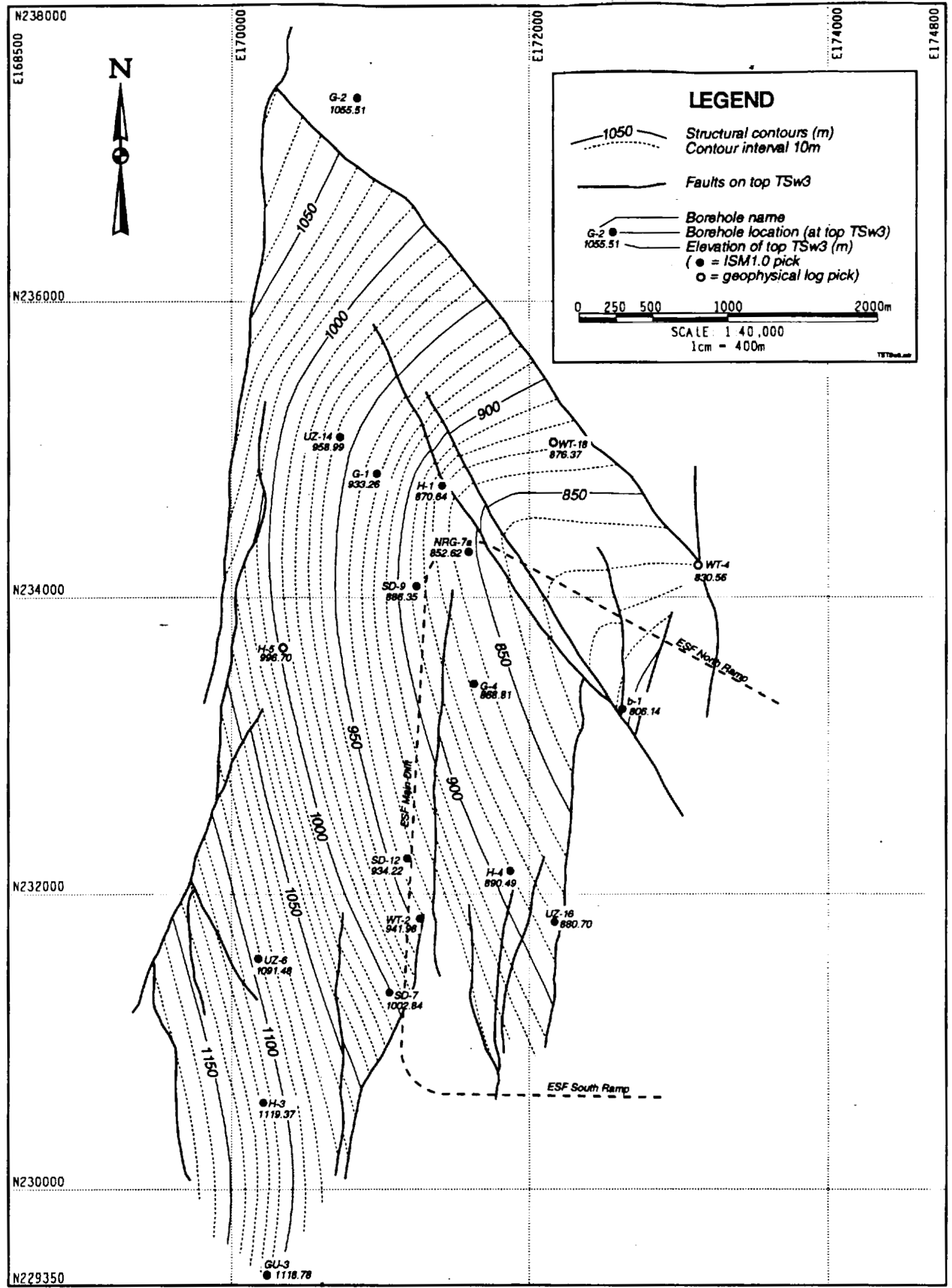

Figure 21. TSw3 unit top surface elevation contours. 


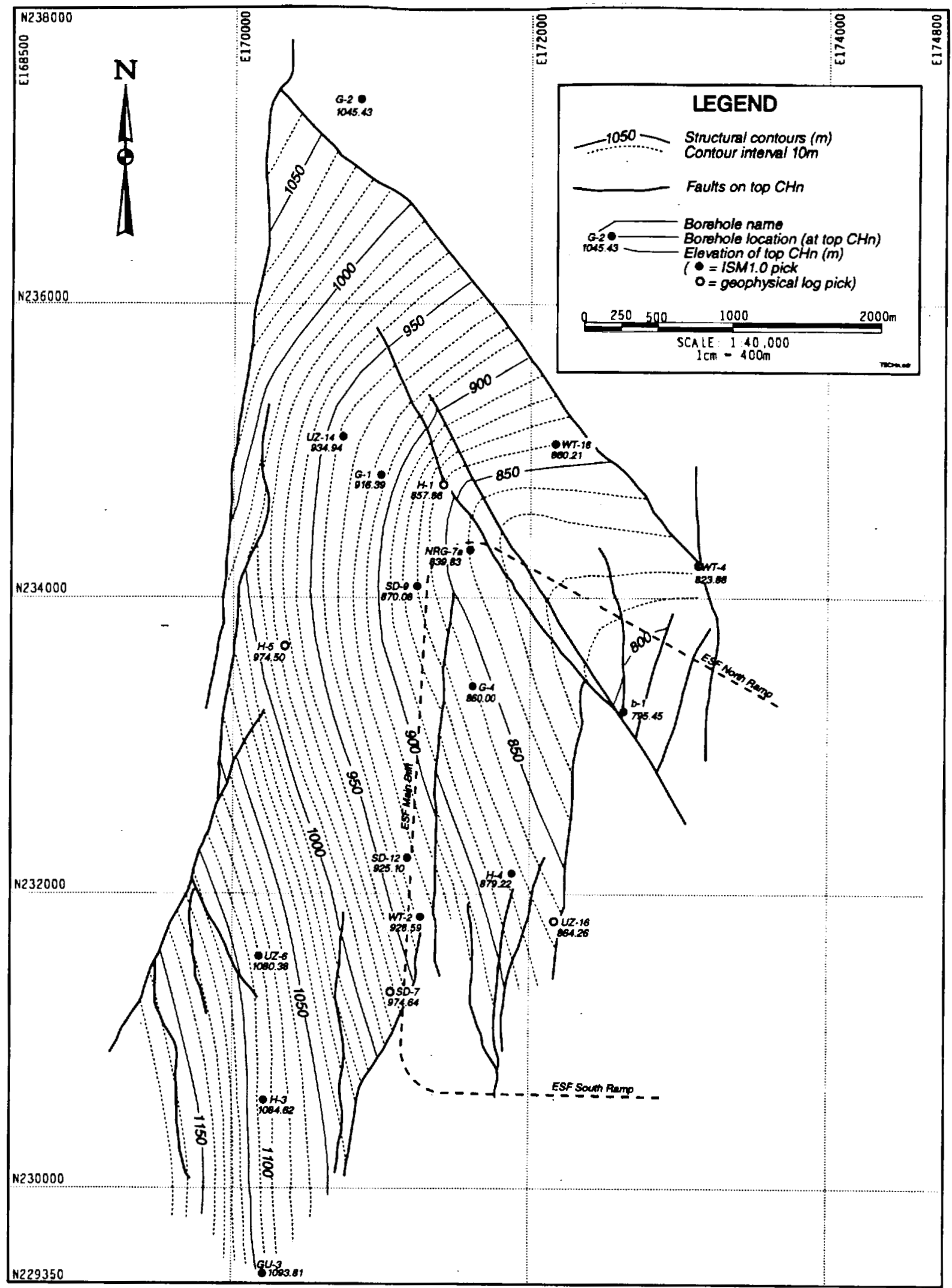

Figure 22. CHn unit top surface elevation contours. 


\subsection{REPOSITORY SITING}

Repository siting is dependent upon a number of limiting factors that define the repository position within the confines of Yucca Mountain in relation to the surrounding geologic conditions and to the accessable environment. Cover limits have been imposed to isolate the emplaced radioactive waste material and prevent possible breaching of the repository through extreme erosion. The geologic horizon selected to host the repository confines the site to what is considered to be the most suitable rock for the repository. Standoff distances from Type I faults are intended to protect the waste from seismic hazards. Finally, the distance to the groundwater table is considered to be great enough so that the repository is not encroached upon by groundwater.

\subsubsection{Previous Work}

Initial siting activities for the repository focused on characterizing geologic units below the water table at Yucca Mountain. By mid-FY 1981, the welded, devitrified portions of the Bullfrog and Tram Members of the Crater Flat Tuff were identified as potential host geologic units. Late in FY 1981 , however, attention was redirected to identify potential repository units in the unsaturated zone above the water table. Based on this work, the welded, devitrified Topopah Spring Tuff of the Paintbrush Group and the nonwelded, highly zeolitized Calico Hills Formation, were identified as potential repository horizons within the unsaturated zone. In FY 1982, Johnstone and others (Reference 5.10) conducted an evaluation of all four potential repository units (Bullfrog, Tram, Topopah Spring, and Calico Hills) and came to the conclusion that the Topopah Spring Tuff unit should be selected as the primary target horizon. A subsequent study by Mansure and Ortiz (Reference 5.8) identified the potentially useable areas for repository siting in the vicinity of Yucca Mountain. Six areas were identified in the area surrounding Yucca Mountain. Area 1, known as the Primary Area, was identified as the most promising site and is centered at Yucca Crest and its eastern flank. This is still identified as the most suitable site for the repository. The siting of the repository block in the Primary Area utilized the Sandia Model (Section 7.1.1) developed by Nimick and Williams (Reference 5.11).

A recent investigation concerning the repository block limits was presented in the $\mathrm{M} \& \mathrm{O}$ design analysis entitled Definition of Repository Block Limits (Reference 5.12). This analysis confirmed that the Primary Area was a suitable area for repository siting. This analysis was later enhanced with more detailed, three-dimensional computer modeling using the LYNX software. The results of this modeling were presented in the technical report entitled Definition of Potential Repository Block (Reference 5.13). The three-dimensional volume of rock available for placement of the repository was identified by computer modeling, using the LYNX software system. The current design analysis updates and replaces this latest definition of the available repository volume.

\subsubsection{Overburden Considerations}

The minimum repository cover shall be $200 \mathrm{~m}$, measured from the crown of the emplacement drift excavation to the directly overlying ground surface (Criteria, Section 4.2.1). According to 10 CFR 960 (Codes and Standards, Section 4.4.1, §960.4-2-5(d)), the site shall be disqualified if site conditions do not allow all portions of the underground facility to be situated at least $200 \mathrm{~m}$ below the directly overlying ground surface. It also states in 10 CFR 960 (Codes and Standards, Section 
4.4.1, $\$ 960.4-2-5(b))$ that a favorable condition is one that permits the emplacement of waste at a depth of at least $300 \mathrm{~m}$ below the directly overlying ground surface. These surfaces are defined in the Design Model as maps (B-* and B3-* in Attachment V) and surface volumes (G.B* and G.B3* in Attachment VI).

To define the $200-\mathrm{m}$ limit in the reference repository analysis plane (Section 7.1.9), the 200-m overburden surface that was constructed from the topography was superimposed on the repository plane elevated to the crown level of the repository (add $7.62 \mathrm{~m}$ to elevation). An overburden limit map was constructed for the upper repository area (Figure 23) and the lower repository expansion area (Figure 24). Both the upper and lower repository areas are within the 200-m overburden limit. Much of the upper repository block area is under more than $300 \mathrm{~m}$ of overburden. Only parts of the lower repository area are under more than $300 \mathrm{~m}$ of overburden.

\subsubsection{Groundwater Considerations}

The groundwater table represents the top of the saturated zone (SZ) barrier that is included in the QList (Reference 5.32). In 10 CFR 960 (Codes and Standards, Section 4.4.1, §960.4-2(5)(ii)), it is stated that a favorable groundwater condition for disposal in the unsaturated zone is where the water table will be sufficiently below the repository block such that the fully saturated voids continuous with the water table do not encounter the repository. Since a standoff was not specified, it was assumed for this design analysis that a $100-\mathrm{m}$ distance above the groundwater table would be sufficient to satisfy the requirement (Assumptions, Section 4.3.6). This surface is defined in the Design Model as a map (GWL_RIB in Attachment V) and surface volume (GGWL, TOP in Attachment VI).

To define this limit in relation to the reference repository planes, thickness maps were constructed to illustrate the distance from the upper and lower repository planes to the groundwater surface. The upper repository area offset distance map is illustrated in Figure 25, and the lower repository expansion area distance map is illustrated in Figure 26.

\subsubsection{Stratigraphic Considerations}

The RHH is assumed to be mostly the TSw2 unit, but may include parts of the overlying TSw1 unit (Assumptions, Section 4.3.2). The TSw2 unit was originally identified as the most suitable horizon for placement of the repository, but due to confusion as to the definition of this unit, the RHH includes the TSw2 unit and the lower part of the overlying TSw1 unit. The limits of the RHH are further restricted in this design analysis to allow for inprecise location of the contacts and for engineering considerations. The standoff from the upper contact of the RHH is assumed to be $5 \mathrm{~m}$ (Assumptions, Section 4.3.4) and the standoff from the lower contact of the RHH is assumed to be $10 \mathrm{~m}$ (Assumptions, Section 4.3.5). These surfaces are defined in the Design Model as maps in Attachment $\mathrm{V}$ and surface volumes in Attachment VI.

To illustrate the relationship of the reference repository planes with these contacts, offset distance maps were constructed for the upper and lower repository planes to the top of the TSw 2 unit (Figures 27 and 28) and the bottom of the TSw2 unit (Figure 29 and 30). The distances shown are from the surface $7.62 \mathrm{~m}$ above the repository invert plane for the TSwl unit and from the invert plane for the 


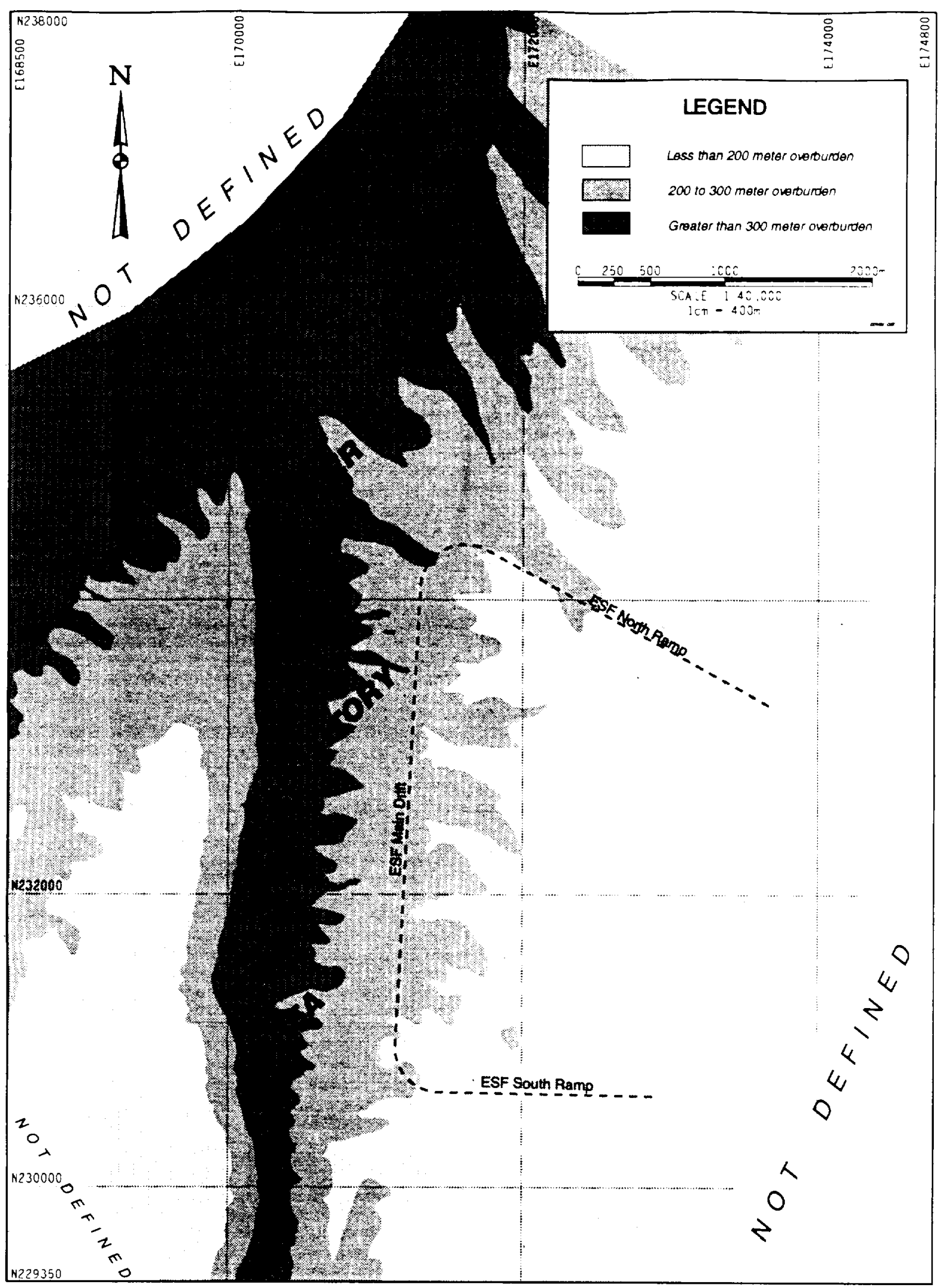

Figure 23. Map showing 200-meter and 300-meter overburden limit lines to the upper reference repository crown level. 
Title: Determination of Available Volume for Repository Siting

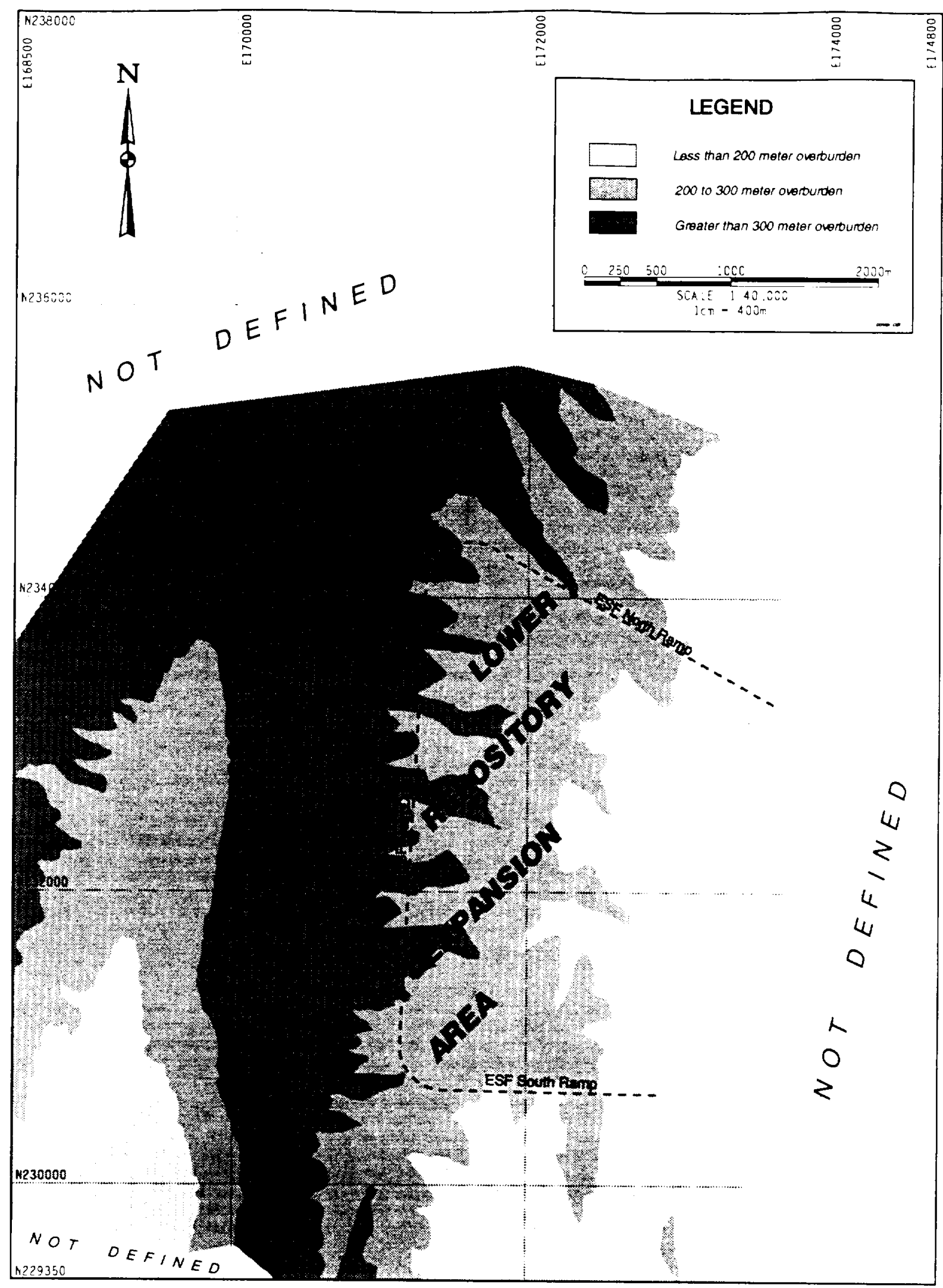

Figure 24. Map showing 200-meter and 300-meter overburden limit lines to the lower reference repository expansion crown level. 
Title: Determination of Available Volume for Repository Siting Document Identifier: BCA000000-01717-0200-00007, Rev.00

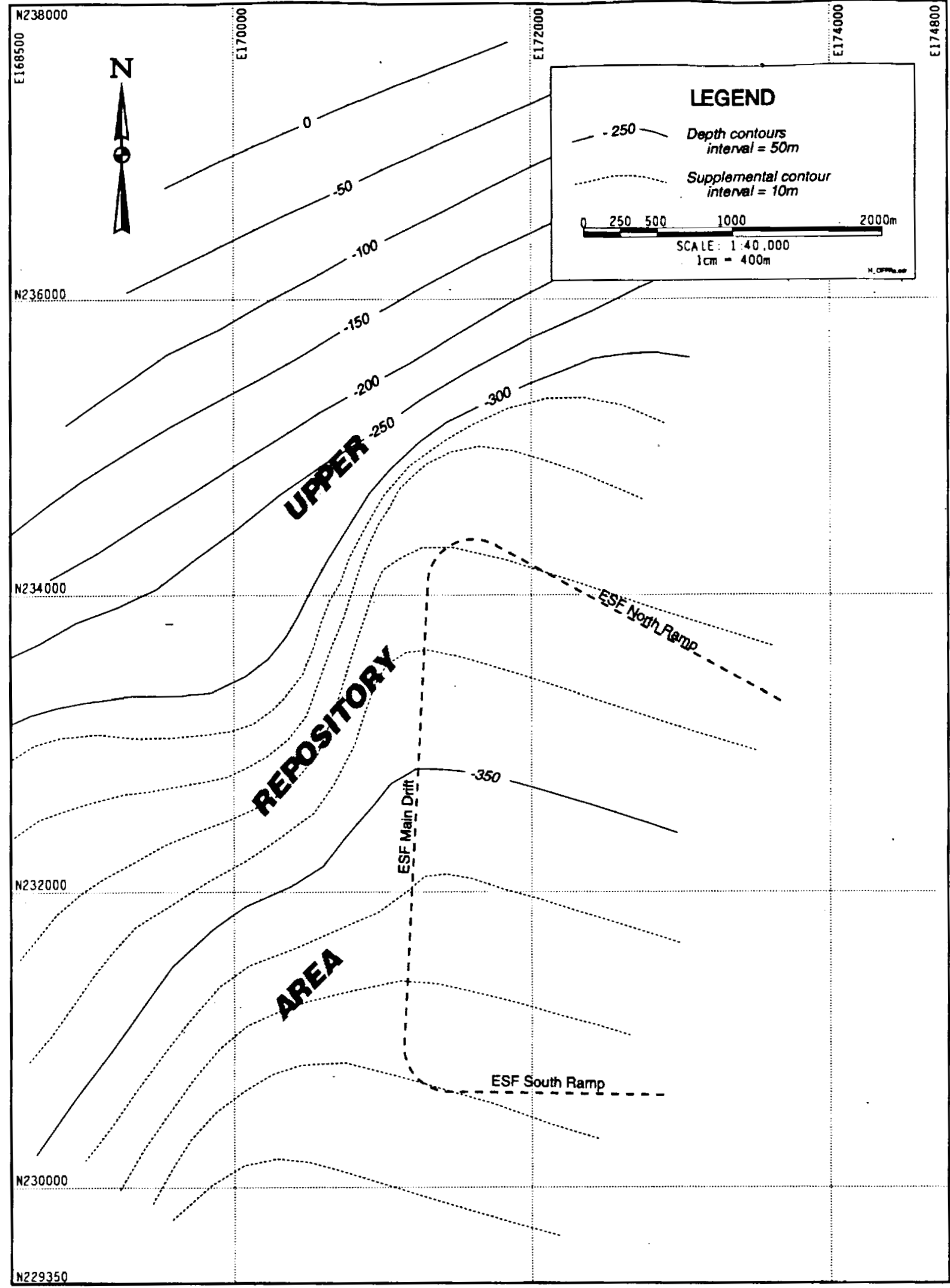

Figure 25. Groundwater table depth below upper reference repository invert level. A groundwater depth of $-100 \mathrm{~m}$ is assumed to be the limit for repository siting. 
Title: Determination of Available Volume for Repository Siting Document Identifier: BCA000000-01717-0200-00007, Rev. 00

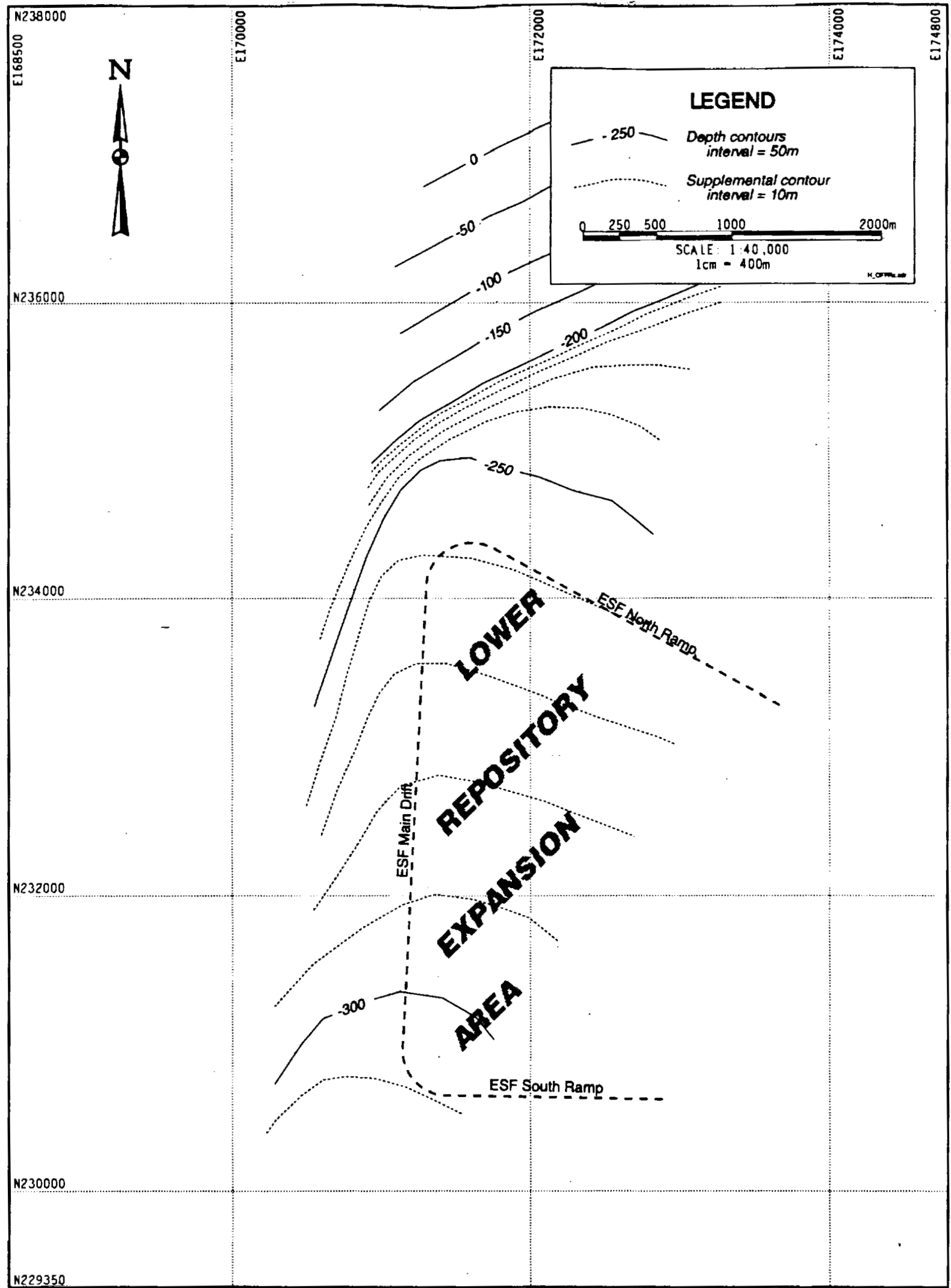

Figure 26. Groundwater table depth below lower reference repository expansion invert level. A groundwater depth of $-100 \mathrm{~m}$ is assumed to be the limit for repository siting. 
TSw3 unit. Assumed standoff distances for these unit contacts were not subtracted from the distances shown.

Another surface that may have thermal implications to the repository siting is the base of the PTn unit (top of the TSw1). The distances in relation to the upper and lower reference repository planes are illustrated in Figure 31 and 32 for the upper and lower repository areas. This distance is measured from the crown level of the repository planes ( $7.62 \mathrm{~m}$ above the invert plane).

\subsubsection{Fault Considerations}

In this design analysis, it is assumed that there are several Type I faults bounding and located within the modeling area (Assumptions, Section 4.3.8). These are identified as:

- Solitario Canyon fault and associated splays

- Ghost Dance fault

- Abandoned wash fault and associated splay

- Dune Wash fault

- Pagany Wash fault

- Bow Ridge fault

- Imbricate faults

Type I faults are defined by the Nuclear Regulatory Commission (NRC) as "those faults or fault zones that may impact repository design and/or performance and, as a result, should undergo detailed investigation"(Reference 5.14, pg. 14). If evaluation of a fault or fault zone leads to inconclusive results, it will be assumed to be Type I (Reference 5.14, pg. 15). The above-named faults are major faults in the area and are therefore assumed to be Type I, pending formal determination.

Type I faults are to be avoided with a 60-m standoff from underground repository openings, except on the western side of the Ghost Dance fault, which requires a $120-\mathrm{m}$ standoff. If avoidance is not possible by design, waste package standoff is required to buffer the fault (Reference 5.2, Assumption 023). The decision as to avoidance using a standoff of repository openings or standoff of waste packages is to be based on engineering judgement. For this reason, the location of these faults are identified, but the siting volume does not consider a standoff from them. Engineering design will determine the best way to avoid these faults.

\subsubsection{Repository Siting Volume}

The potential repository siting volume is defined by a number of criteria and limiting factors:

- 200-m overburden surface

- 5-m standoff below the top of the Repository Host Horizon

- 10-m standoff above bottom of the Repository Host Horizon

- $100-\mathrm{m}$ above top of groundwater table

- Type I faults 
Title: Determination of Available Volume for Repository Siting Document Identifier: BCA000000-01717-0200-00007, Rev. 00

Page: 70 of 81

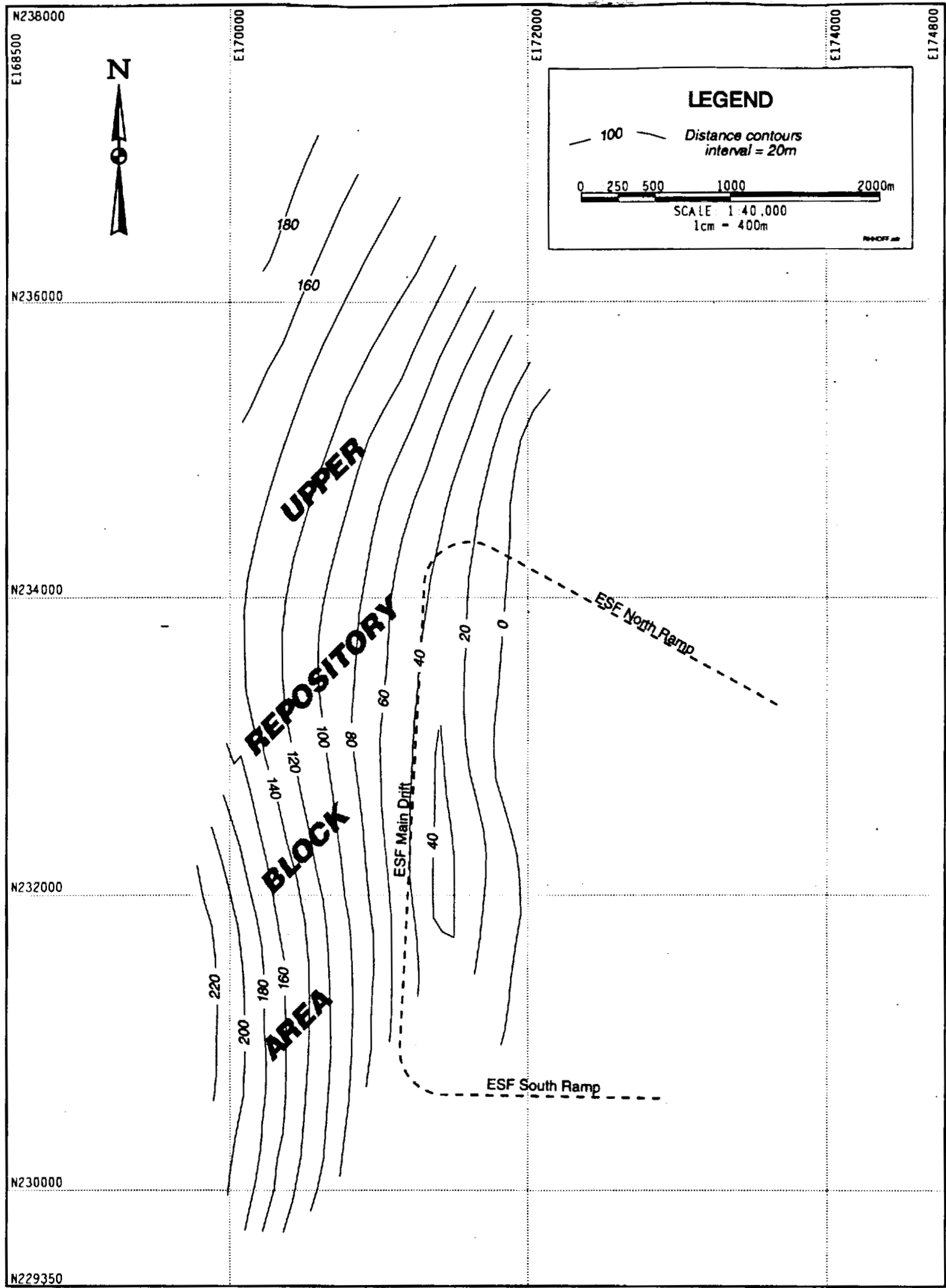

Figure 27. Distance to top of Repository Host Horizon $(\mathrm{RHH})$ from upper reference repository crown level. 
Title: Determination of Available Volume for Repository Siting Document Identifier: BCA000000-01717-0200-00007, Rev. 00

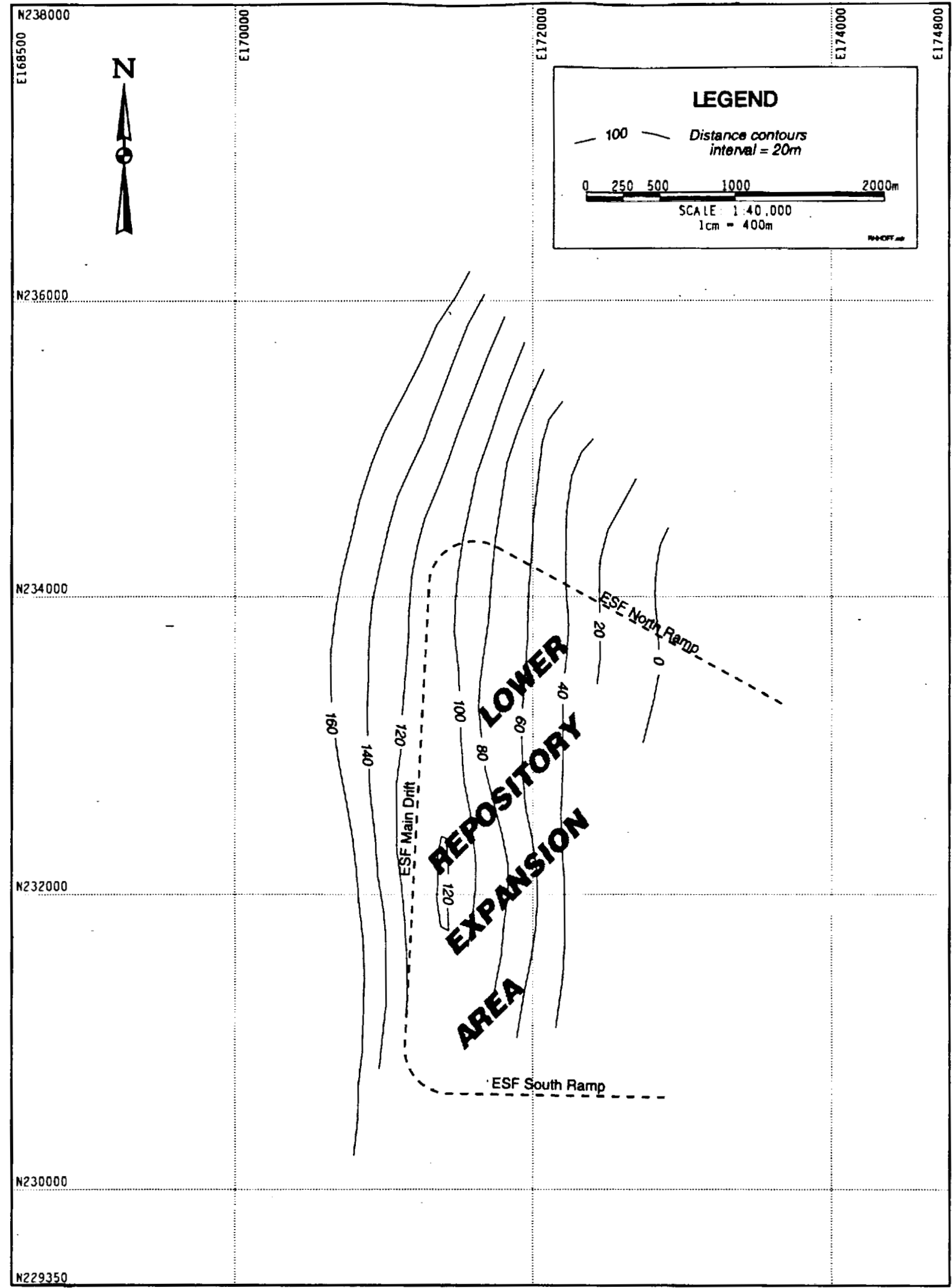

Figure 28. Distance to top of Repository Host Horizon (RHH) from lower reference repository expansion crown level. 


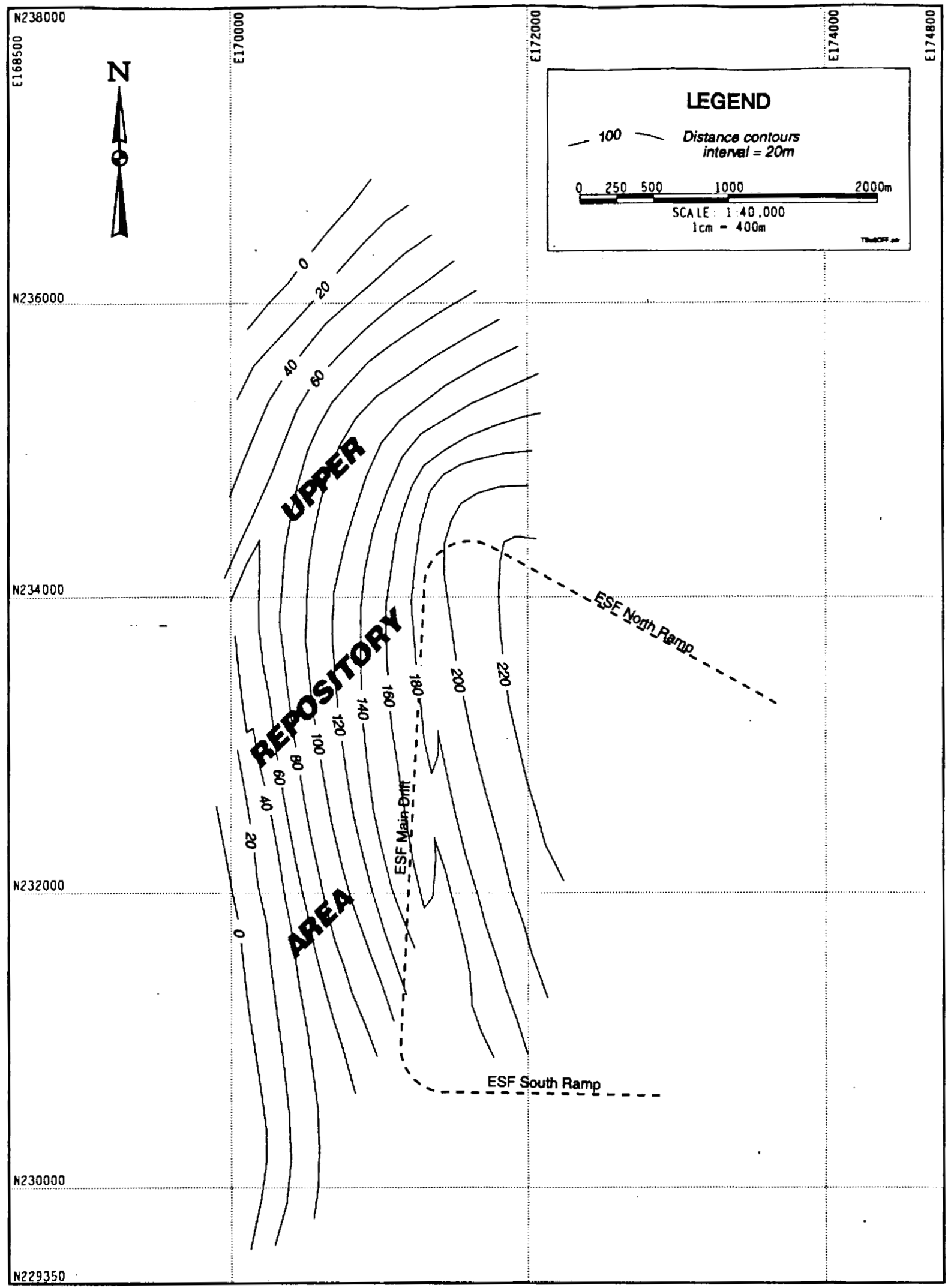

Figure 29. Distance to bottom of Repository Host Horizon (top TSw3) from upper reference repository invert level. 


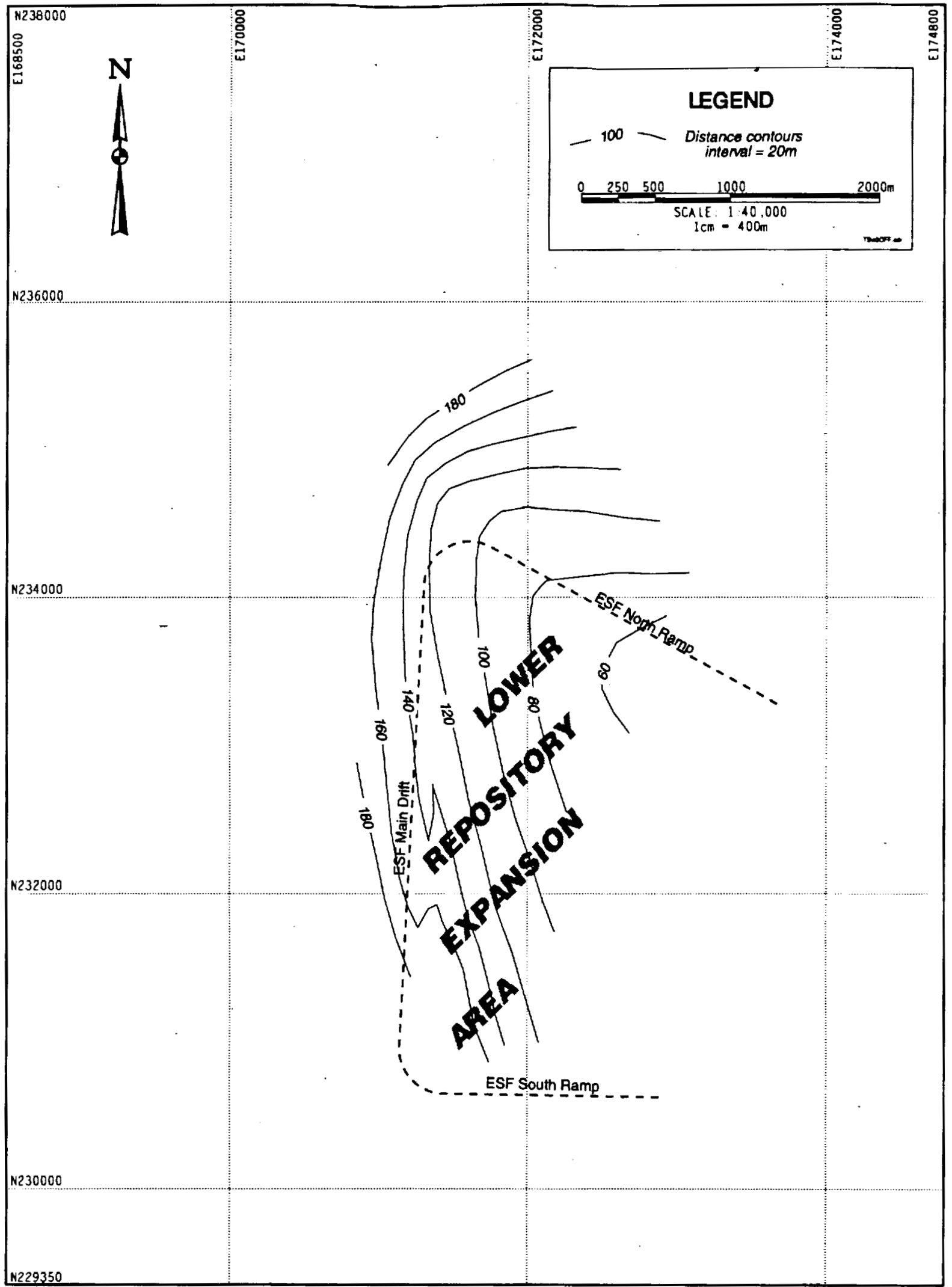

Figure 30. Distance to bottom of Repository Host Horizon (top TSw3) from lower reference repository expansion invert level. 
Title: Determination of Available Volume for Repository Siting Document Identifier: BCA000000-01717-0200-00007, Rev. 00

Page: 74 of 81

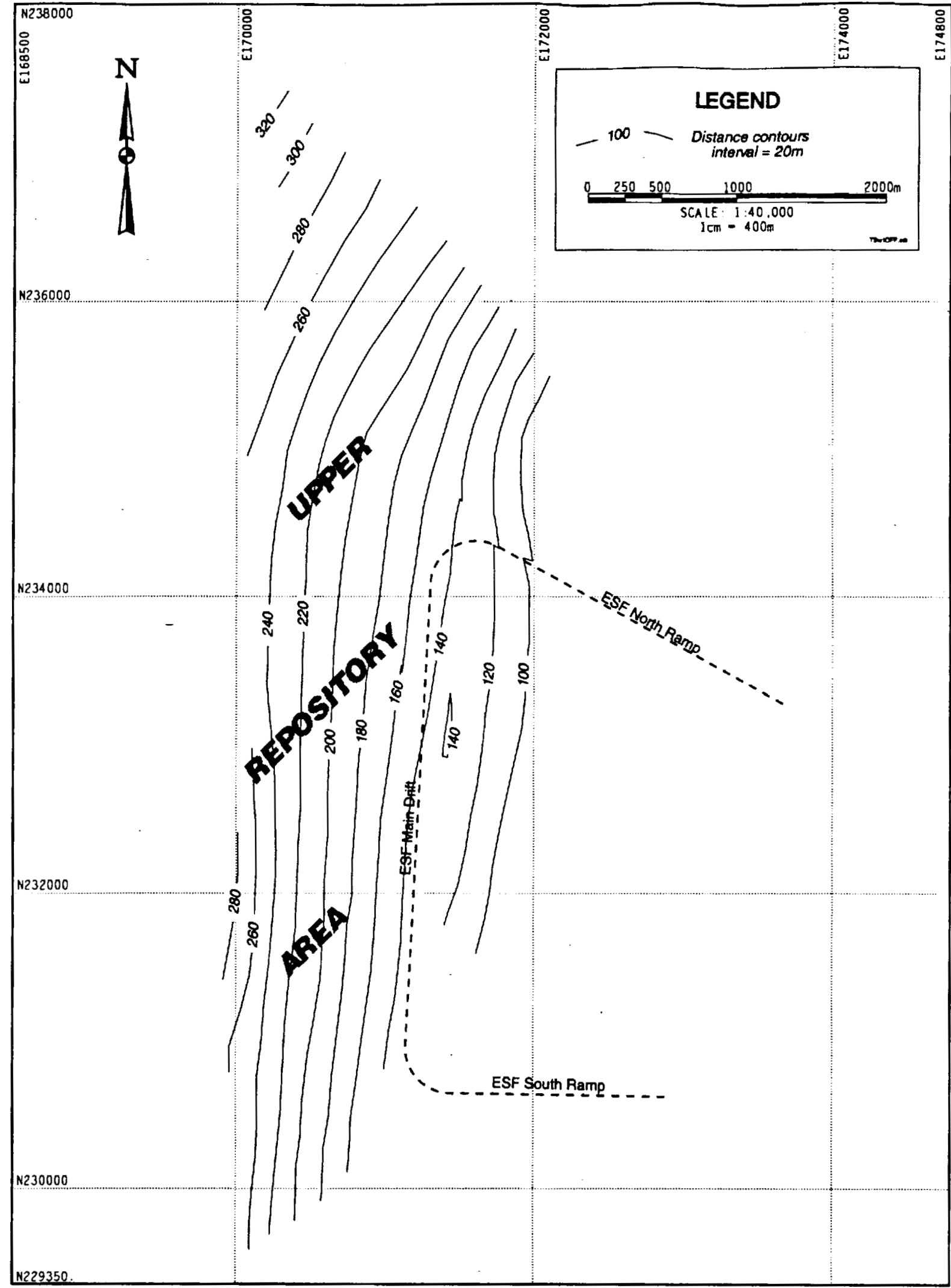

Figure 31. Distance to top of TSw1 (bottom PTn) from upper reference repository crown level. 
Title: Determination of Available Volume for Repository Siting Document Identifier: BCA000000-01717-0200-00007, Rev. 00

Page: 75 of 81

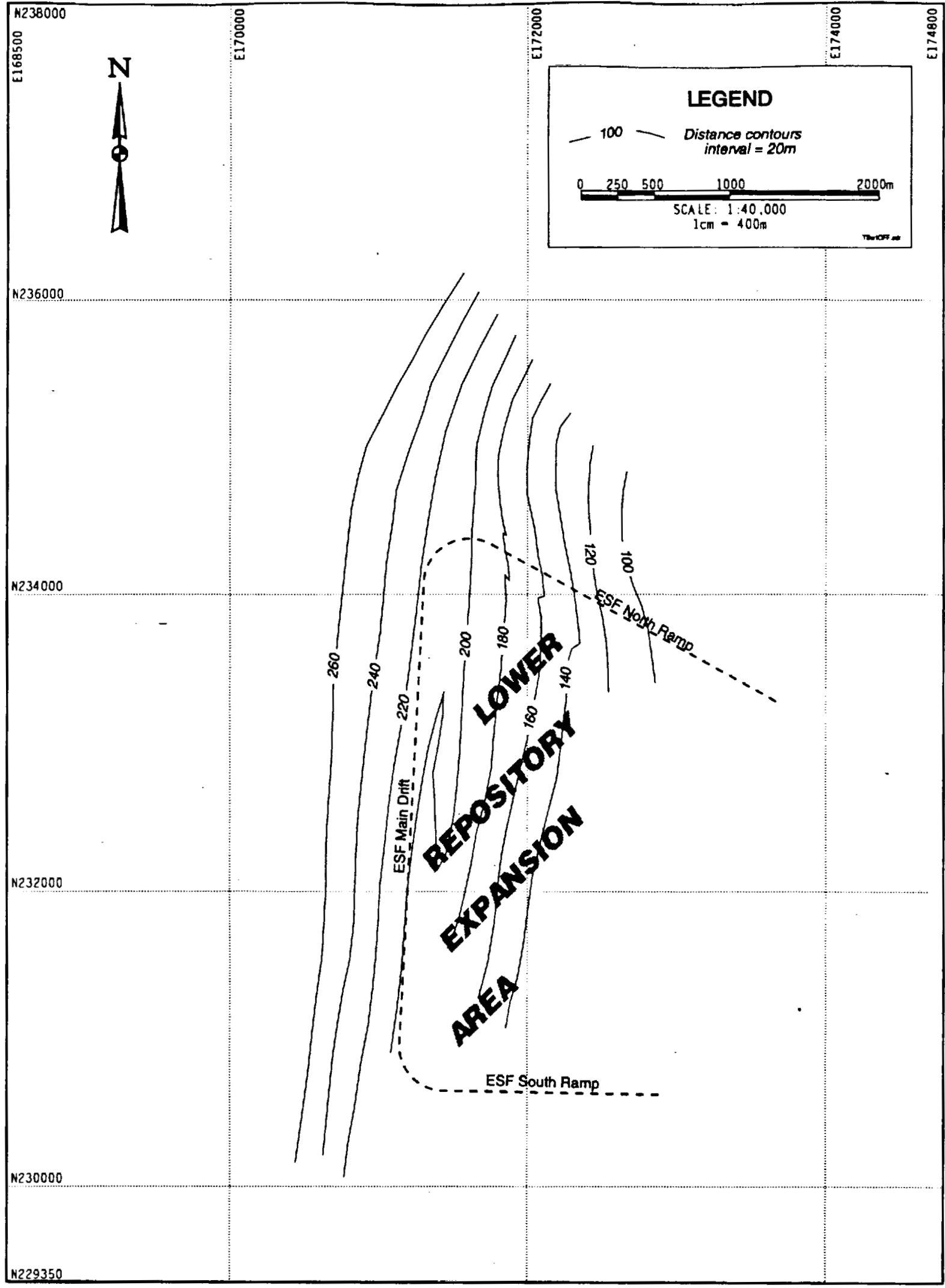

Figure 32. Distance to top of TSw1 (bottom PTn) from lower reference repository expansion crown level. 
The upper limit of the repository siting volume is defined by either the $5-\mathrm{m}$ standoff below the top of the RHH, or the $200-\mathrm{m}$ overburden surface, whichever is at the lowest elevation. The lower limit is defined by either the $10-\mathrm{m}$ standoff above the bottom of the RHH, or the surface $100-\mathrm{m}$ above the top of the groundwater table, whichever is higher. The lateral limits are defined by the location of the major fault planes. The standoff from these faults will be considered during engineering design of the repository.

Based on these limits, available repository siting area maps for the upper and lower reference repository area were constructed in the Design Model by superimposing the siting limits onto the repository planes. The siting map for the upper repository block is shown in Figure 33 and for the lower expansion block is shown in Figure 34.

The upper reference repository siting area covers about $9.5 \mathrm{sq} \mathrm{km} \mathrm{(2350} \mathrm{ac).} \mathrm{This} \mathrm{is} \mathrm{in} \mathrm{comparison}$ to the $7.5 \mathrm{sq} \mathrm{km}(1850 \mathrm{ac}$ ) identified in the Primary Area by Mansure and Ortiz (Reference 5.8). The lower lithophysal zone rocks (Tptpll) comprise about half of this area. The lower reference repository expansion siting area covers about $8.7 \mathrm{sq} \mathrm{km} \mathrm{(2150} \mathrm{ac).} \mathrm{Rocks} \mathrm{of} \mathrm{the} \mathrm{lower} \mathrm{lithophysal}$ zone (Tptpll) comprise over half of this area.

The volume available for repository siting within the above-listed constraints is best illustrated by a series of cross sections drawn through the upper and lower repository block areas (Figure 35). Because of scale, These cross sections do not show the upper 5-m and lower 10-m standoff from the top and bottom of the RHH. The upper reference repository level and lower reference repository expansion level are shown in the sections.

\section{CONCLUSIONS}

The geologic horizon that is considered to be suitable for hosting the repository is identified herein as the RHH. It consists of the entire TSw2 unit and the lower part of the TSw1 unit (Figure 5). The lithostratigraphic zones contained within the RHH are, from top to bottom, the lower part of the upper lithophysal zone (informally named the Tptpull), the middle nonlithophysal zone, the lower lithophysal zone, and the lower nonlithophysal zone. The RHH contains both lithophysal and nonlithophysal rocks, but the rock of the RHH typically contains fewer lithphysal cavities and is of higher density than the directly overlying upper part of the upper lithophysal zone, referred to informally herein as Tptpulu. Underlying the RHH is the basal vitrophyre (TSw3) of the Topopah Spring Tuff.

To define the three-dimensional volume available for repository siting, a computer model was developed using the LYNX geology and engineering modeling software. The model, referred to in this design analysis as the Design Model, is identified in the LYNX system as YMP.MO3Q. This model is one of many that have been developed over the years for the Yucca Mountain Project. It takes into account all the most recent information on the geology of the site. The Design Model was developed using data from the Technical Data Base and stratigraphic picks from both core and geophysical log analysis. The stratigraphic units modeled included the thermal/mechanical units TSw1, TSw2, and TSw3. The lithostratigraphic zones making up the TSw2 unit, including the 
Title: Determination of Available Volume for Repository Siting

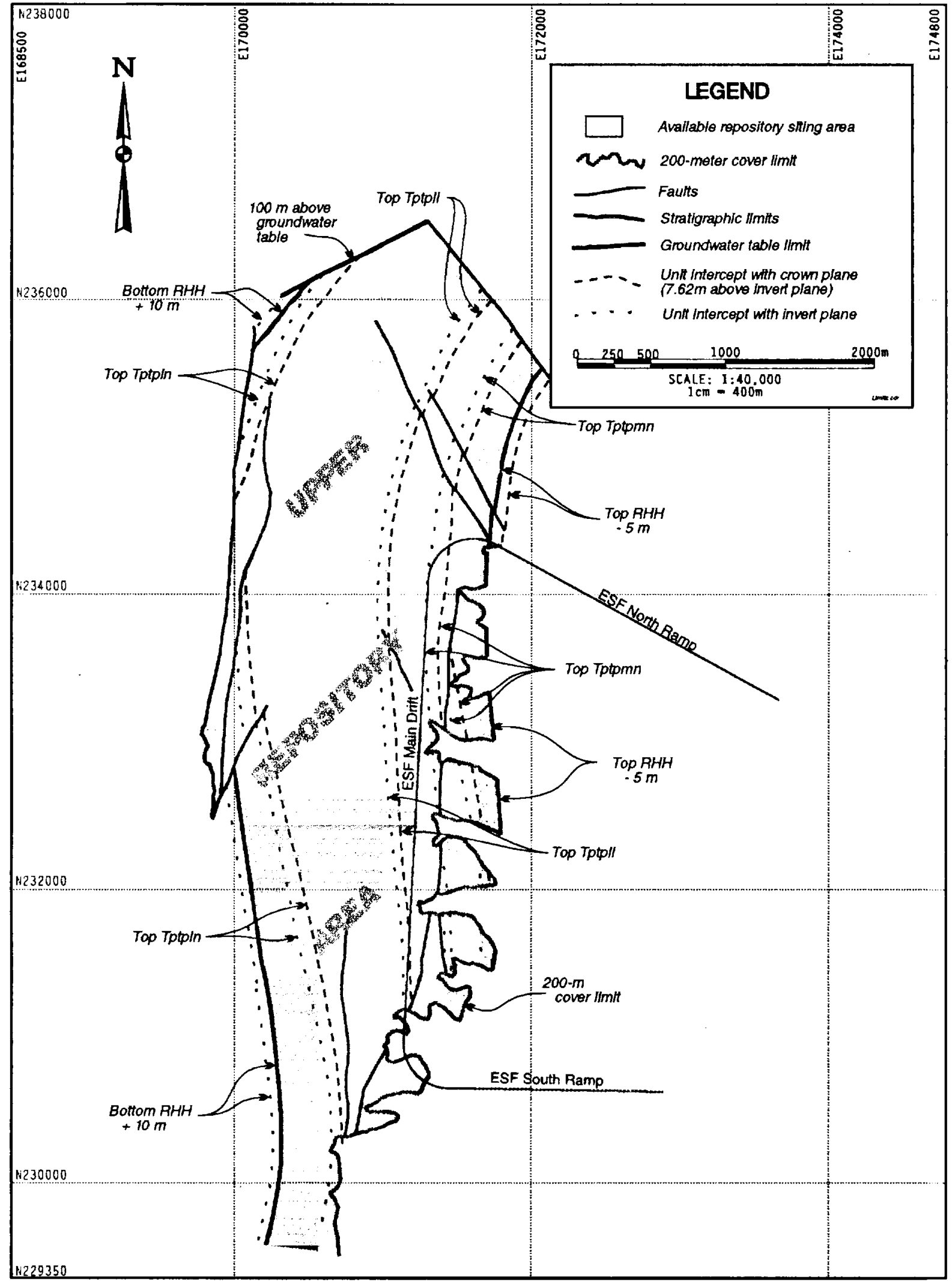

Figure 33. Available repository siting area for upper reference repository level showing limits and distribution of stratigraphic units. 
Title: Determination of Available Volume for Repository Siting

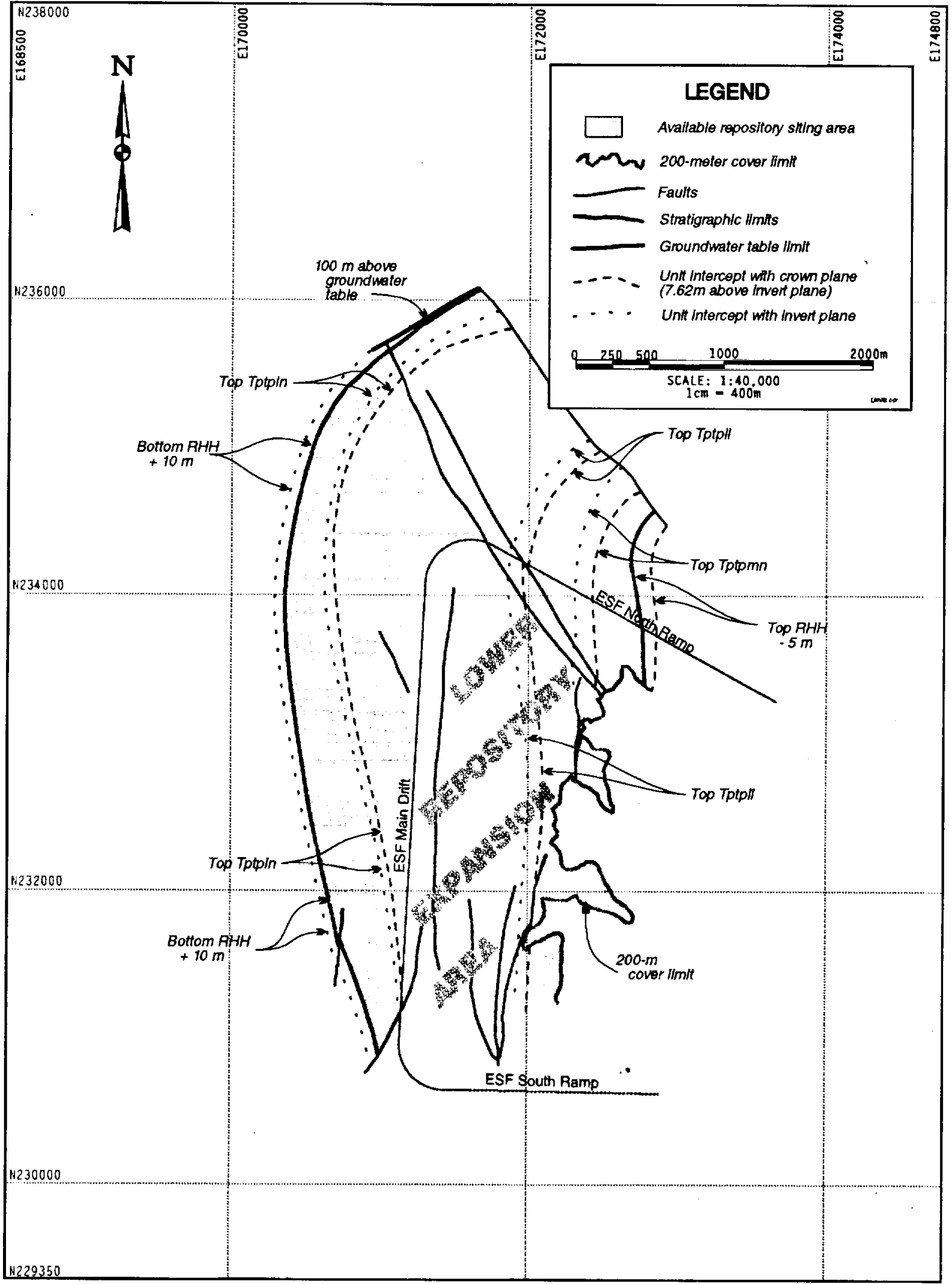

Figure 34. Available repository siting area for lower reference repository expansion level showing limits and distribution of stratigraphic units. 
Title: Determination of Available Volume for Repository Siting

Document Identifier: BCA000000-01717-0200-00007, Rev. 00
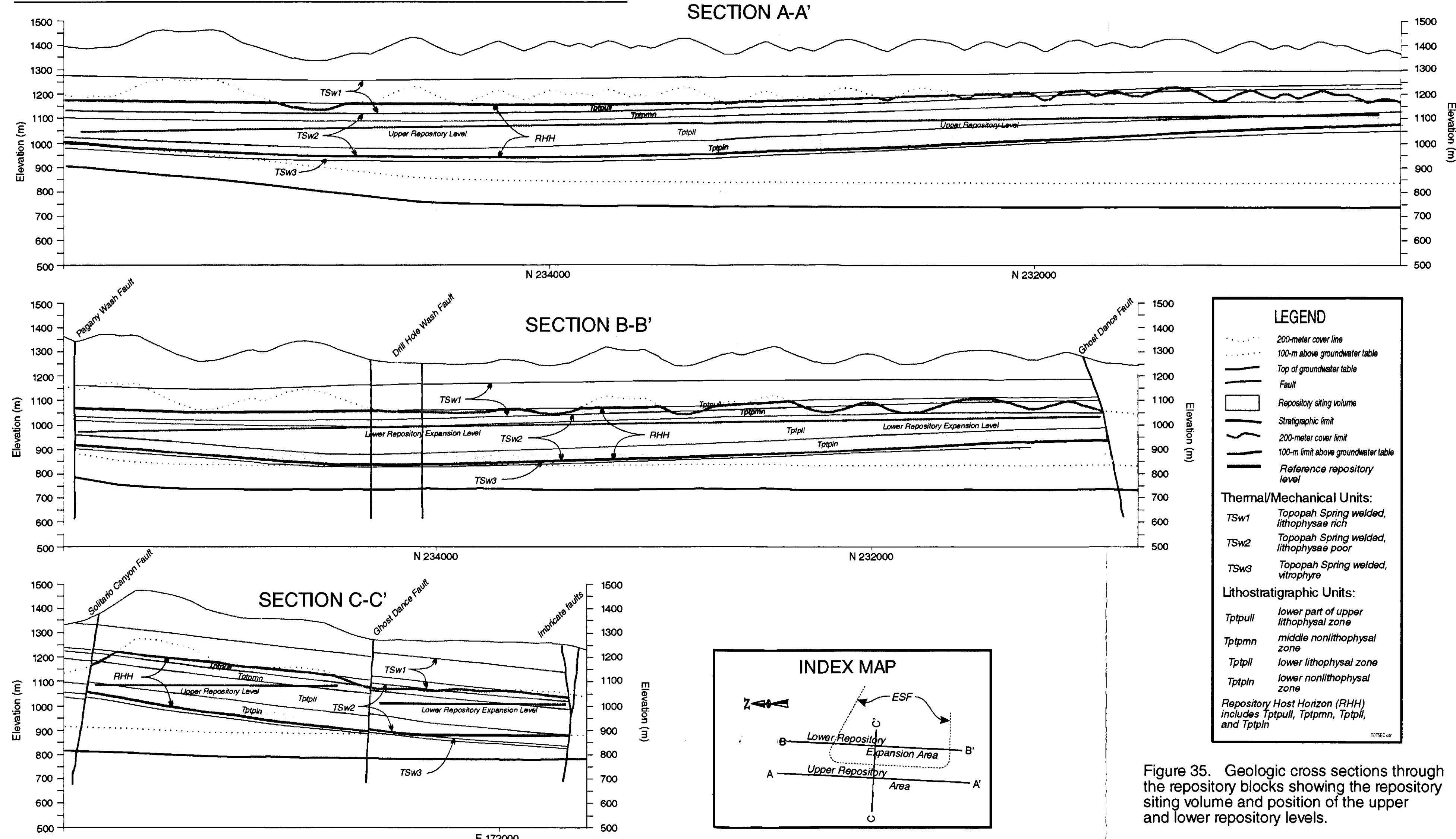

232000

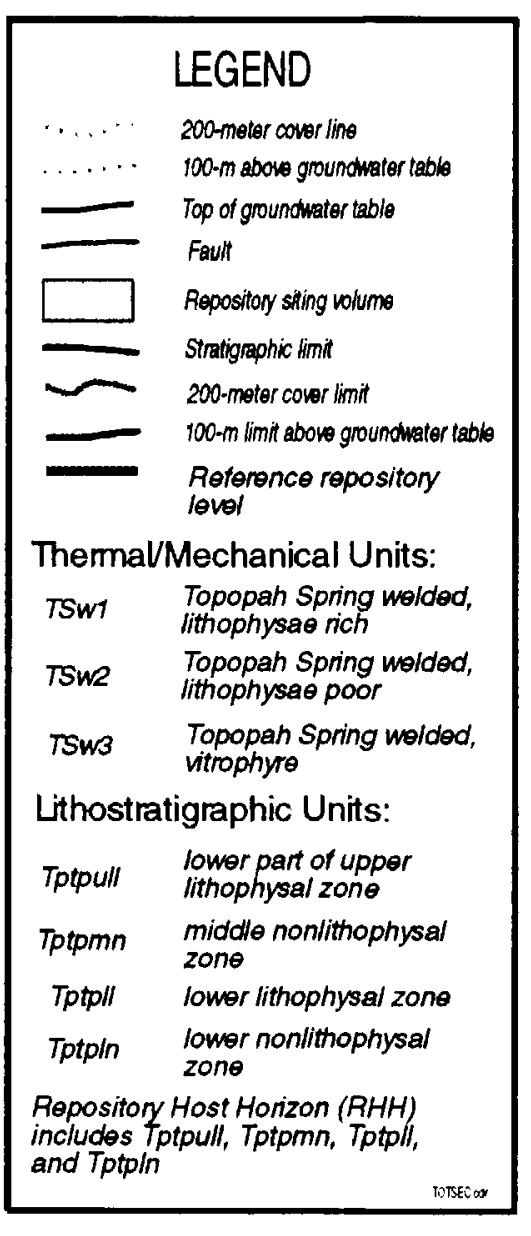

Figure 35. Geologic cross sections through the repository blocks showing the repositon siting volume and position of the upper and lower repository levels. 
middle nonlithophysal, lower lithophysal, and lower nonlithophysal, were also modeled to provide detail within the TSw2 unit. The RHH top and bottom were also included in the model.

The limiting factors included in the Design Model identify the extent of the available repository volume. The upper limit of the repository is defined by either the 5-m standoff below the top of the $\mathrm{RHH}$ or the $200-\mathrm{m}$ overburden surface, whichever is at the lowest elevation. The lower limit is defined by either the $10-\mathrm{m}$ standoff above the bottom of the RHH or the surface $100-\mathrm{m}$ above the top of the groundwater table, whichever is higher. The lateral limits are defined by the location of the major fault planes minus a $60-\mathrm{m}$ standoff, except for the Ghost Dance fault, which has a $120-\mathrm{m}$ standoff on the west side. Using this volume model, repository siting alternatives can easily be examined and analyzed as to their relationship to the defined limits. With the LYNX system, cross sections can be cut through any location and any angle to illustrate the volume.

This Design Model was built with currently available geologic data that were collected over a wide span of years and under various QA programs. The inputs therefore have a wide range of QA pedigrees from qualified to non-qualified. Because this analysis utilized both qualified and nonqualified data, it is considered to be preliminary and non-qualified, and likewise, the Design Model is preliminary and non-qualified. The non-qualified status of the model does not preclude it from being used as input to other analyses, as long as the analysis is not in support of construction, fabrication, or procurement. As the input data is updated or added to, the Design Model will be revised as necessary to stay current. In order to update this model to a status of qualification suitable for input to construction, fabrication, and procurement, existing data needs to be qualified and additional data needs to be collected. Minimally, the following input item needs to be addressed:

- Qualified topography is needed to define qualified 200-m overburden limit.

- Qualified collar and down-hole location data (deviation survey) needed for control of borehole stratigraphic data.

- Qualified geologic unit borehole depth picks needed for stratigraphic control.

- Borehole is needed for stratigraphic control of the lower limits of the repository volume in the southwestern part of the upper repository siting area.

- Qualified map representation of the groundwater surface.

- Determine suitable standoff requirements from adjacent stratigraphic units.

- Identify faults in the central block that are to be treated as Type I faults

- Determine suitable standoff requirements from Type I faults.

- Determine subsurface location of Solitario fault, particularly in the northeastern part of the upper repository siting area.

\section{ATTACHMENTS}

$\begin{array}{lll}\text { Attachment } & \text { Pages } & \text { Description } \\ \text { I } & 1 & \text { Borehole Data Qualification Status and Source } \\ \text { II } & 11 & \text { Borehole Data Listing for the Design Model } \\ \text { III } & 1 & \text { Average Groundwater Level Data Listing for the Design Model } \\ \text { IV } & 1 & \text { List of Borehole Data Subsets Included in the Design Model } \\ \text { V } & 4 & \text { List of Maps Included in the Design Model }\end{array}$


Title: Determination of Available Volume for Repository Siting

Document Identifier: BCA000000-01717-0200-00007, Rev. 00

Page: 81 of 81

VI

VII

VIII
2

6

13
List of Geology and Engineering Volume Models Included in the Design Model

Directory Listing for Archived Tape of the Design Model Source Code Listing of UNIX Shell Scripts used in the Design Model 


\section{Attachment I}

BOREHOLE DATA QUALIFICATION STATUS AND SOURCE

$(\mathrm{Q}=$ qualified, Non- $\mathrm{Q}=$ non-qualified, None=data not available)

\begin{tabular}{|c|c|c|c|c|c|c|}
\hline \multirow[b]{2}{*}{ Borehole } & \multirow[b]{2}{*}{ Area } & \multicolumn{5}{|c|}{ Data Qualification Status and Reference } \\
\hline & & $\begin{array}{c}\text { Collar } \\
\text { Location } \\
\text { (Tech. Data } \\
\text { Base) }\end{array}$ & $\begin{array}{c}\text { Core Log } \\
\text { (Ref. 5.45) }\end{array}$ & $\begin{array}{c}\text { Bulk Density } \\
\text { Log } \\
\text { (Ref. 5.61') }\end{array}$ & $\begin{array}{c}\text { Deviation } \\
\text { Survey } \\
\left(\text { Ref. 5.40') }^{1}\right)\end{array}$ & $\begin{array}{l}\text { Q Status for } \\
\text { Stratigraphic } \\
\text { Control Picks } \\
\text { (this design } \\
\text { analysis) }\end{array}$ \\
\hline G-1 & USW & Non-Q & Non-Q & $\mathrm{Q}$ & Non-Q & Non-Q \\
\hline G-2 & USW & Non-Q & Non-Q & $\mathrm{Q}$ (Ref. 5.49) & Non-Q & Non-Q \\
\hline$\overline{G-3}$ & USW & Non-Q & None & None & None & Non-Q \\
\hline GU-3 & USW & Non-Q & Non-Q & $\mathrm{Q}$ & Non-Q & Non-Q \\
\hline $\mathrm{G}-4$ & USW & Non-Q & Non-Q & $Q$ & Non-Q & Non-Q \\
\hline $\mathrm{H}-1$ & USW & Non-Q & Non-Q & Q & Non-Q & Non-Q \\
\hline $\mathrm{H}-3$ & USW & Non-Q & Non-Q & $Q$ & Non-Q & Non-Q \\
\hline $\mathrm{H}-4$ & USW & Non-Q & Non-Q & Q & Non-Q & Non-Q \\
\hline $\mathrm{H}-5$ & USW & $\mathrm{Q}$ & Non-Q & $\mathrm{Q}$ & Non-Q & Non-Q \\
\hline NRG-4 & UE-25 & Q & $Q$ & Q (Ref. 5.55) & Q (Ref. 5.55) & $Q$ \\
\hline NRG-5 & UE-25 & Q & $Q$ & $\mathrm{Q}$ (Ref. 5.55) & $Q$ (Ref. 5.55) & $Q$ \\
\hline NRG-6 & USW & Q & Q & $\mathrm{Q}$ (Ref. 5.55) & $\mathrm{Q}$ (Ref. 5.55) & Q \\
\hline NRG-7a & USW & Q & Q & Q (Ref. 5.55) & Q (Ref. 5.55) & $\mathrm{Q}$ \\
\hline SD-7 & USW & Q & $\mathrm{N}$ & $\mathrm{Q}$ (Ref. 5.54) & $Q$ (Ref. 5.54) & Non-Q \\
\hline SD-9 & USW & Q & $\mathrm{Q}$ & $\mathrm{Q}$ (Ref. 5.52) & $\mathrm{Q}$ (Ref. 5.52) & $Q$ \\
\hline SD-12 & USW & $\mathrm{Q}$ & $Q$ & Q (Ref. 5.53) & $\mathrm{Q}$ (Ref. 5.53 ) & $\mathrm{Q}$ \\
\hline UZ-1 & USW & Non-Q & Non-Q & $\bar{Q}$ & None & Non-Q \\
\hline UZ-5 & UE-25 & Non-Q & Non-Q & Q (Ref. 5.50) & None & Non-Q \\
\hline UZ-6 & USW & Non-Q & Non-Q & $\mathrm{Q}$ & Non-Q & Non-Q \\
\hline UZ-7a & USW & $\mathbf{Q}$ & Non-Q & $\mathrm{Q}(\operatorname{Ref} .5 .51)$ & Q (Ref. 5.51) & Non-Q \\
\hline UZ-14 & USW & $\mathrm{Q}$ & $\mathrm{Q}$ & $Q$ (Ref. 5.58) & $Q$ (Ref. 5.58) & Q \\
\hline UZ-16 & UE-25 & Non-Q & $\mathrm{Q}$ & $\mathrm{Q}$ (Ref. 5.57) & None & Non-Q \\
\hline UZN-31 & USW & Non-Q & Q & None & None & Non-Q \\
\hline UZN-32 & USW & Non-Q & $\mathrm{Q}$ & None & None & Non-Q \\
\hline UZN-37 & USW & $\mathbf{Q}$ & $Q$ & None & None & Non-Q \\
\hline UZN-55 & USW & $Q$ & $\mathrm{Q}$ & None & None & Non-Q \\
\hline WT-2 & USW & $\bar{Q}$ & Non-Q & Q (Ref. 5.56) & Non-Q & Non-Q \\
\hline WT-4 & UE-25 & Non-Q & Non-Q & Q & Non-Q & Non-Q \\
\hline WT-18 & UE-25 & Non-Q & Non-Q & $\mathrm{Q}$ & Non-Q & Non-Q \\
\hline$a-4$ & UE-25 & Non-Q & Non-Q & Non-Q & None & Non-Q \\
\hline$a-5$ & UE-25 & Non-Q & Non-Q & $\mathrm{Q}$ & None & Non-Q \\
\hline$a-6$ & UE-25 & Non-Q & Non-Q & Q & None & Non-Q \\
\hline$a-7$ & UE-25 & $Q$ & Non-Q & $\mathrm{Q}$ & None & Non-Q \\
\hline b-1 & UE-25 & Non-Q & Non-Q & $\mathrm{Q}$ & Non-Q & Non-Q \\
\hline
\end{tabular}

${ }^{1}$ Unless otherwise noted. 


\section{Attachment II \\ BOREHOLE DATA LISTING FOR THE DESIGN MODEL}

The boreholes included in the following data listing all fall within the area modeled in the Design Model, except for USW G-2, which is just north of the area and was used for model control. The ESF data points from the underground mapping are also included (Reference 5.44).

Collar location data for the boreholes are from the Technical Data Base (02/06/97 listing) expressed in metric units. The northing, easting, and elevation values in the database were truncated to two decimal places for use in modeling.

The thermal/mechanical stratigraphic nomenclature is according to Ortiz and others (Reference 5.17) and are identifed under the 'T/M Unit' column. The thermal/mechanical units identified include:

$$
\begin{aligned}
& 1=\text { Topopah }{ }^{-} \text {Spring welded lithophysal unit (TSw1) } \\
& 2=\text { Topopah Spring welded nonlithophysal unit (TSw2) } \\
& 3=\text { Topopah Spring vitrophyre unit (TSw3) } \\
& \text { CHn = Calico Hills nonwelded unit }
\end{aligned}
$$

Also shown in the 'T/M Unit' column is the Repository Host Horizon (RHH).

The lithostratigraphic nomenclature is according to Buesch and others (Reference 5.1). Lithostratigraphic zones are identified under the 'Lith. Unit' column and include:

Tptpull = informal zone used in this design analysis to identify the rocks situated between the top of the RHH and the top of the Tptpmn zone

Tptpmn = Topopah Spring, crystal poor, middle nonlithophysal zone

Tptpll = Topopah Srping, crystal poor, lower lithophysal zone

Tptpln = Topopah Spring, lower nonlithophysal zone

Stratigraphic depth data (borehole depth) given are for the unit tops and were taken from the Yucca Mountain Project Stratigraphic Compendium (Reference 5.45 and Design Parameters Section 4.1.2), unless identified otherwise in the 'Comments' column. The source of the ISM data is identified as core log or cuttings log in the 'Comments' colmun. Some contacts were identified from the geophysical logs (References listed in Attachment I, Design Parameters Section 4.1.2) because there were discrepancies of greater than one meter between the core log and geophysical log. These are indicated in the 'Comments' column as geophysical log picks. Where geophysical picks were taken over the ISM data, the original ISM data is given for reference in parentheses in the 'Comments' column. Questionable geophysical log picks are identified as such. 
Depth is as measured down the borehole and is not corrected for deviation. Elevation and thickness numbers are calculated by the LYNX system and take deviation into consideration. For this reason, the thicknesses may not add up correctly. In the ISM reference, stratigraphic depths are given in English units rounded to the nearest foot, so these were converted to metric (using $0.3048 \mathrm{~m} / \mathrm{ft}$ ), then truncated to two decimal places. Elevations are displayed in the 'Elevation' column and are calculated by the Lynx system using available borehole deviation survey data. Thicknesses are given in the 'Thickness' column and are apparent borehole thicknesses. Incomplete sections are identified with 'Inc' in the 'Thickness' column. Incomplete thickness results if a borehole bottoms in the unit or if the top or bottom contact for the unit could not be recognized.

Borehole: G-1

Area: USW

Northing

$2 \overline{34848.46}$

\begin{tabular}{|c|c|c|}
\hline & Area: USW & Q Status: Non-Q \\
\hline Easting & Elevation & Total depth \\
\hline 170992.95 & 1325.45 & 1828.80 \\
\hline
\end{tabular}

\begin{tabular}{|c|c|c|c|c|c|}
\hline Unit & Lith. Unit & Depth & Elevation & Thickness & Comments \\
\hline 1 & - & 82.29 & 1243.16 & 100.58 & Cuttings log. No geophysical log. \\
\hline \multirow{5}{*}{$\begin{array}{l}\mathbf{R} \\
\mathbf{H} \\
\mathbf{H}\end{array}$} & & 182.88 & 1142.58 & $\overline{209.32}$ & Lithophysal cavity estimate pick. Poor \\
\hline & Tptpull & 182.88 & 1142.58 & 34.58 & \\
\hline & Tptpmn & 217.44 & 1108.02 & 30.90 & Cuttings log. \\
\hline & Tptpll & 248.35 & 1077.12 & 117.12 & Cuttings log. \\
\hline & Tptpln & 365.52 & 960.00 & 26.74 & Core log. \\
\hline 3 & & 392.28 & 933.26 & 16.87 & Core $\log$. \\
\hline CHn & - & 409.16 & 916.39 & Inc & Core log. \\
\hline
\end{tabular}

Borehole: G-2

Area: USW

\begin{tabular}{|c|c|c|c|}
\hline Northing & Easting & Elevation & Total depth \\
\hline 237385.61 & 170841.58 & 1553.99 & 1830.63 \\
\hline
\end{tabular}

\begin{tabular}{|c|c|c|c|c|c|}
\hline $\begin{array}{l}\text { T/M } \\
\text { Unit }\end{array}$ & Lith. Unit & Depth & Elevation & Thickness & Comments \\
\hline 1 & - & 233.72 & 1320.33 & 111.27 & Core log. No geophysical log. \\
\hline \multirow{5}{*}{$\begin{array}{l}\mathbf{R} \\
\mathbf{H} \\
\mathbf{H}\end{array}$} & & 345.00 & 1209.06 & 153.55 & Geophysical log/lithophysal cavity estimate pick. \\
\hline & Tptpull & 345.00 & 1209.06 & 35.81 & \\
\hline & Tptpmn & 380.82 & 1173.25 & 19.97 & Core log. \\
\hline & Tptpll & 400.80 & 1153.27 & 73.17 & $\begin{array}{l}\text { Core } \log (387.55) \text {. Geophysical log pick, } \\
\text { questionable. }\end{array}$ \\
\hline & Tptpln & 474.00 & 1080.10 & 24.59 & $\begin{array}{l}\text { Core } \log (488.90) \text {. Geophysical log pick, } \\
\text { questionable. }\end{array}$ \\
\hline 3 & - & 498.62 & 1055.51 & 10.08 & Core log. \\
\hline CHn & - & 508.71 & 1045.43 & Inc & Core log. \\
\hline
\end{tabular}

Borehole: G-3

Area: USW

Q Status: Non-Q

\begin{tabular}{|c|c|c|c|}
\hline Northing & Easting & Elevation & Total depth \\
\hline 229447.30 & 170225.66 & 1480.26 & 1563.93 \\
\hline
\end{tabular}

No stratigraphic data 
Title: Determination of Available Volume for Repository Siting

Borehole: GU-3

Area: USW

Q Status: Non-Q

\begin{tabular}{|c|c|c|c|}
\hline Northing & Easting & Elevation & Total depth \\
\hline 229419.94 & 170231.20 & 1480.29 & 805.89 \\
\hline
\end{tabular}

\begin{tabular}{|c|c|c|c|c|c|}
\hline $\begin{array}{l}\text { T/M } \\
\text { Unit }\end{array}$ & Lith. Unit & Depth & Elevation & Thickness & Comments \\
\hline 1 & - & 130.39 & 1349.93 & 78.37 & Core log \\
\hline \multirow{5}{*}{$\begin{array}{l}\mathbf{R} \\
\mathbf{H} \\
\mathbf{H}\end{array}$} & & 208.80 & 1271.56 & 152.78 & Geophysical log/lithophysal cavity estimate pick. \\
\hline & Tptpull & 208.80 & 1271.56 & 13.18 & \\
\hline & Tptpmn & 221.99 & 1258.38 & 33.99 & Core log. \\
\hline & Tptpll & 256.00 & 1224.39 & 62.15 & $\begin{array}{l}\text { Core } \log (275.51) \text {. Geophysical log pick, } \\
\text { questionable. }\end{array}$ \\
\hline & Tptpln & 318.21 & 1162.24 & 43.46 & Core log. \\
\hline 3 & - & 361.71 & 1118.78 & 24.97 & Core log. Poor geophysical log. \\
\hline$\overline{\mathbf{C H n}}$ & - & 386.70 & 1093.81 & Inc & Core log. Poor geophysical log. \\
\hline
\end{tabular}

Borehole: G-4

Area: USW

Northing

233418.00

\begin{tabular}{c|r} 
& Area: USW \\
\hline Easting & Elevation \\
\hline 171627.28 & 1270.07 \\
\hline
\end{tabular}

Q Status: Non-Q $17 \overline{1627.28}$ 1270.07 Total depth 915.31

\begin{tabular}{|c|c|c|c|c|c|c|}
\hline $\begin{array}{l}T / 1 \\
\text { Un }\end{array}$ & & Lith. Unit & Depth & Elevation & Thickness & Comments \\
\hline 1 & & - & -72.84 & 1197.23 & 115.53 & Core log. \\
\hline \multirow{5}{*}{\multicolumn{2}{|c|}{$\begin{array}{l}\mathbf{R} \\
\mathbf{H} \\
\mathbf{H}\end{array}$}} & & 188.37 & 1081.71 & 212.89 & Geophysical log pick. Questionable. \\
\hline & & Tptpull & 188.37 & 1081.71 & 18.89 & \\
\hline & & Tptpmn & 207.26 & 1062.82 & 27.44 & Core log. \\
\hline & & Tptpll & $23 \overline{4.70}$ & 1035.38 & 109.08 & Core log. \\
\hline & & Tptpln & 343.78 & 926.30 & $57 . \overline{49}$ & Core log. \\
\hline 3 & & - & 401.27 & 868.81 & 8.81 & Core $\log$. \\
\hline \multicolumn{2}{|c|}{$\mathrm{CHn}$} & - & 410.08 & 860.00 & Inc & Core log. \\
\hline
\end{tabular}

Borehole: $\mathbf{H}-\mathbf{1}$

Area: USW

\begin{tabular}{|r|}
\hline Northing \\
\hline 234773.52 \\
\hline
\end{tabular}

\begin{tabular}{c} 
Easting \\
171415.85 \\
\hline
\end{tabular}
Elevatio 1302.84 Q Status: Non-Q

\begin{tabular}{|c|c|c|c|c|c|}
\hline $\begin{array}{l}\text { T/M } \\
\text { Unit }\end{array}$ & Lith. Unit & Depth & Elevation & Thickness & Comments \\
\hline 1 & - & 98.45 & 1204.39 & 99.67 & Cuttings log. \\
\hline \multirow{5}{*}{$\begin{array}{l}\mathbf{R} \\
\mathbf{H} \\
\mathbf{H}\end{array}$} & & 198.12 & 1104.72 & 234.08 & Geophysical log pick. Questionable. \\
\hline & Tptpull & 198.12 & 1104.72 & 34.44 & \\
\hline & Tptpmn & 232.56 & 1063.57 & 35.05 & Geophysical log pick. \\
\hline & Tptpll & 274.32 & 1028.52 & 129.24 & Cuttings log. \\
\hline & Tptpln & 403.56 & 899.29 & 28.65 & Core log. \\
\hline \multirow{2}{*}{$\frac{3}{\mathrm{CHn}}$} & - & 432.21 & 870.64 & 12.78 & Cuttings log. \\
\hline & - & 444.99 & 857.86 & Inc & Cuttings $\log$ (no depth).Geophysical log pick. \\
\hline
\end{tabular}


Title: Determination of Available Volume for Repository Siting

Attachment II

Document Identifier: BCA000000-01717-0200-00007, Rev. 00

Page: 4 of 11

Borehole: H-3

Area: USW

Northing

230594.03

\begin{tabular}{|c|c|c|} 
& Area: USW & Q Status: Non-Q \\
\hline Easting & Elevation & Total depth \\
\hline 170216.06 & 1483.28 & $\frac{1219.20}{128}$ \\
\hline
\end{tabular}

\begin{tabular}{|c|c|c|c|c|c|}
\hline $\begin{array}{l}\text { T/M } \\
\text { Unit }\end{array}$ & Lith. Unit & Depth & Elevation & Thickness & Comments \\
\hline 1 & - & 134.42 & 1348.87 & 49.98 & Cuttings log. \\
\hline \multirow{5}{*}{\begin{tabular}{l|l}
$\mathbf{R}$ & 1 \\
$\mathbf{H}$ & \\
$\mathbf{H}$ & $\mathbf{2}$
\end{tabular}} & & 184.40 & 1298.89 & 179.51 & Geophysical log pick. Questionable \\
\hline & Tptpull & 184.40 & 1298.89 & 22.89 & \\
\hline & Tptpmn & 207.29 & 1276.00 & 51.21 & Cuttings log. \\
\hline & Tptpll & 258.50 & 1224.79 & 61.51 & Cuttings log. \\
\hline & Tptpln & 320.01 & 1163.28 & 43.91 & Cuttings log. \\
\hline 3 & - & 363.92 & 1119.37 & 34.75 & Cuttings log. \\
\hline CHn & - & 398.68 & 1084.62 & Inc & Cuttings log. \\
\hline
\end{tabular}

Borehole: H-4

Area: USW

Q Status: Non-Q

\begin{tabular}{|c|c|c|c|}
\hline Northing & Easting & Elevation & Total depth \\
\hline 232148.98 & 171880.11 & 1248.61 & 1219.20 \\
\hline
\end{tabular}

\begin{tabular}{|c|c|c|c|c|c|}
\hline $\begin{array}{l}\text { T/M } \\
\text { Unit }\end{array}$ & Lith. Unit & Depth & Elevation & Thickness & Comments \\
\hline 1 & - & 77.11 & 1171.51 & 75.28 & Cuttings log. \\
\hline \multirow{5}{*}{$\begin{array}{l}\mathbf{R} \\
\mathbf{H} \\
\mathbf{H}\end{array}$} & & -152.40 & 1096.22 & 205.74 & Geophysical log pick. Questionable. \\
\hline & Tptpull & 152.40 & 1096.22 & 25.91 & \\
\hline & Tptpmn & 178.31 & 1070.31 & 37.50 & Cuttings log. \\
\hline & Tptpll & 215.81 & 1032.82 & 89.87 & Cuttings log. \\
\hline & Tptpln & 305.68 & 942.95 & 52.46 & Cuttings log. \\
\hline 3 & & 358.14 & 890.49 & 11.28 & Cuttings log. \\
\hline $\mathbf{C H n}$ & - & 369.42 & 879.22 & Inc & Cuttings log. \\
\hline
\end{tabular}

Borehole: H-5

Area: USW

Q Status: Non-Q

\begin{tabular}{|c|c|c|c|}
\hline Northing & Easting & Elevation & Total depth \\
\hline 233670.08 & 170355.28 & 1478.83 & 1219.20 \\
\hline
\end{tabular}

\begin{tabular}{|c|c|c|c|c|c|}
\hline $\begin{array}{l}\text { T/M } \\
\text { Unit }\end{array}$ & Lith. Unit & Depth & Elevation & Thickness & Comments \\
\hline 1 & - & 170.69 & 1308.15 & 113.06 & Cuttings log. \\
\hline \multirow{6}{*}{$\begin{array}{l}\mathbf{R} \\
\mathbf{H} \\
\mathbf{H}\end{array}$} & & 283.77 & 1195.09 & 198.40 & Geophysical log pick. Questionable. \\
\hline & Tptpull & 283.77 & 1195.09 & 21.03 & \\
\hline & Tptpmn & 304.80 & 1174.06 & 30.17 & Cuttings log. \\
\hline & Tptpll & 334.98 & 1143.89 & 91.69 & Cuttings log. \\
\hline & Tptpln & 426.69 & 1052.20 & 55.50 & Cuttings log. \\
\hline & 1. & 482.20 & 996.70 & 22.20 & Cuttings log $(480.06)$. Geophysical log pick. \\
\hline $\mathbf{C H n}$ & - & 504.40 & 974.50 & Inc & Cuttings $\log (502.92)$. Geophysical log pick. \\
\hline
\end{tabular}


Title: Determination of Available Volume for Repository Siting

Borehole: NRG-4

\begin{tabular}{|c|c|c|c|}
\hline Northing & Easting & Elevation & Total depth \\
\hline 233806.05 & 172766.73 & 1249.52 & 221.28 \\
\hline
\end{tabular}

\begin{tabular}{|c|c|c|c|c|c|}
\hline $\begin{array}{l}\text { T/M } \\
\text { Unit }\end{array}$ & Lith. Unit & Depth & Elevation & Thickness & Comments \\
\hline 1 & - & 147.83 & 1101.70 & Inc & Core log. Bottom in TSw1 \\
\hline
\end{tabular}

Borehole: NRG-5

\begin{tabular}{|c|c|c|c|}
\hline Northing & Easting & Elevation & Total depth \\
\hline 234052.75 & 172141.86 & 1251.71 & 411.48 \\
\hline
\end{tabular}

\begin{tabular}{|c|c|c|c|c|c|c|}
\hline $\begin{array}{l}\text { T/N } \\
\text { Uni }\end{array}$ & & Lith. Unit & Depth & Elevation & Thickness & Comments \\
\hline 1 & & - & 100.58 & 1151.14 & 106.95 & Cuttings log. \\
\hline \multicolumn{3}{|l|}{$\mathbf{R}$} & 207.57 & 1044.19 & Inc & $\begin{array}{l}\text { Geophysical log pick. No core/estimate of } \\
\text { lithophysal cavities. }\end{array}$ \\
\hline $\mathbf{H}$ & 1 & Tptpull & 207.57 & 1044.19 & 35.02 & \\
\hline \multirow[t]{2}{*}{$\mathbf{H}$} & \multirow{2}{*}{2} & Tptpmn & 242.62 & 1009.17 & 32.12 & Core log. \\
\hline & & Tptpll & 274.78 & 977.05 & Inc & Core log. Bottom in Tptpll. \\
\hline
\end{tabular}

Borehole: NRG-6

Area: USW

Q Status: Q

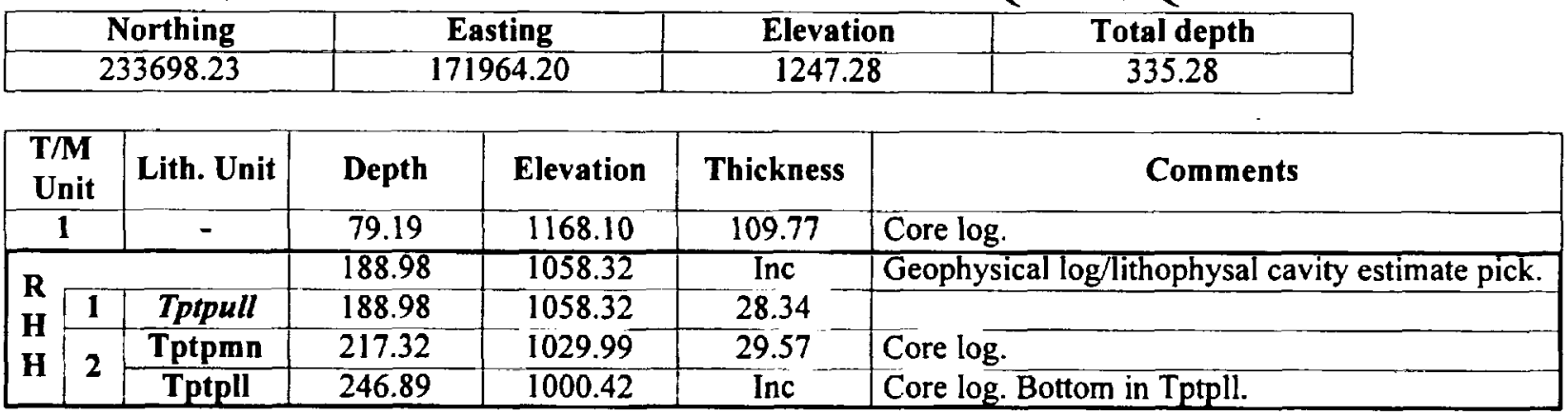

Borehole: NRG-7a

Area: USW

Q Status: Q

\begin{tabular}{|c|c|c|c|}
\hline Northing & Easting & Elevation & Total depth \\
\hline 234354.66 & 171597.52 & 1282.35 & 461.28 \\
\hline
\end{tabular}

\begin{tabular}{|c|c|c|c|c|c|}
\hline $\begin{array}{l}\mathbf{T} / \mathbf{M} \\
\text { Unit }\end{array}$ & Lith. Unit & Depth & Elevation & Thickness & Comments \\
\hline 1 & - & 90.28 & 1192.18 & 110.16 & Core log. \\
\hline \multirow{5}{*}{$\begin{array}{l}\mathbf{R} \\
\mathbf{H} \\
\mathbf{H}\end{array}$} & & 200.86 & 1082.02 & 229.39 & Geophysical log/lithophysal cavity estimate pick. \\
\hline & Tptpull & 200.86 & 1082.02 & 33.27 & \\
\hline & Tptpmn & 234.24 & 1048.74 & 33.15 & Core log. \\
\hline & Tptpll & 267.49 & 1015.59 & 106.48 & Core log. \\
\hline & Tptpln & 374.45 & 909.12 & 56.50 & Core log. \\
\hline 3 & $=$ & $431 . \overline{23}$ & 852.62 & 12.80 & Core log. \\
\hline $\mathrm{CHn}$ & - & 444.09 & 839.83 & Inc & Core log. \\
\hline
\end{tabular}


Title: Determination of Available Volume for Repository Siting

Attachment II

Document Identifier: BCA000000-01717-0200-00007, Rev. 00

Page: 6 of 11

Borehole: SD-7

Northing

231327.92

\begin{tabular}{|c|c|c|}
\multicolumn{2}{c}{ Area: USW } & Q Status: Non-Q \\
\hline Easting & Elevation & Total depth \\
\hline 171066.03 & 1363.07 & 710.18 \\
\hline
\end{tabular}

\begin{tabular}{|c|c|c|c|c|c|c|}
\hline $\begin{array}{l}\mathbf{T} 7 \\
\mathbf{U}\end{array}$ & & Lith. Unit & Depth & Elevation & Thickness & Comments \\
\hline 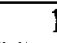 & & - & 117.74 & 1245.34 & 77.32 & Core log. \\
\hline \multirow{5}{*}{\multicolumn{2}{|c|}{$\mathbf{H}$}} & & 195.07 & 1168.01 & 165.18 & $\begin{array}{l}\text { Geophysical log pick. No estimate of lithophysal } \\
\text { cavities. }\end{array}$ \\
\hline & & Tptpull & 195.07 & 1168.01 & 12.96 & \\
\hline & & Tptpmn & 208.03 & 1155.05 & 32.76 & Core $\log (195.07)$. Geophysical log pick. \\
\hline & & Tptpll & 240.79 & 1122.29 & 70.11 & Core $\log (252.68)$. Geophysical log pick. \\
\hline & & Tptpln & 310.90 & 1052.19 & 49.35 & Core log. Poor geophysical log. \\
\hline 3 & & - & 360.27 & 1002.84 & 28.19 & Core log. \\
\hline \multicolumn{2}{|c|}{$\mathbf{C H n}$} & - & 388.48 & 974.64 & Inc & Core $\log (391.67)$. Geophysical log pick. \\
\hline
\end{tabular}

Borehole: SD-9

Area: USW Q Status: Q

\begin{tabular}{|c|c|c|c|}
\hline Northing & Easting & Elevation & Total depth \\
\hline 234085.94 & 171242.13 & 1302.30 & 677.61 \\
\hline
\end{tabular}

\begin{tabular}{|c|c|c|c|c|c|c|}
\hline \multirow{2}{*}{\multicolumn{2}{|c|}{$\begin{array}{c}\text { T/M } \\
\text { Unit } \\
1\end{array}$}} & Lith. Unit & Depth & Elevation & Thickness & Comments \\
\hline & & - & -81.83 & 1220.47 & 109.57 & Core log. \\
\hline \multirow{5}{*}{\multicolumn{2}{|c|}{$\begin{array}{l}\mathbf{R} \\
\mathbf{H} \\
\mathbf{H}\end{array}$}} & & 191.41 & 1110.90 & 224.54 & Geophysical log/lithophysal cavity estimate pick. \\
\hline & & Tptpull & $19 \overline{1.41}$ & 1110.90 & 33.17 & \\
\hline & & Tptpmn & 224.58 & 1077.73 & 33.22 & Core log. \\
\hline & & Tptpll & 257.80 & 1044.51 & 103.58 & Core log. \\
\hline & & Tptpln & $361 . \overline{43}$ & 940.93 & 54.58 & Core log. Poor geophysical log. \\
\hline $\mathbf{3}$ & & - & 416.05 & 886.35 & 16.27 & Core log. \\
\hline \multicolumn{2}{|c|}{ CHn } & - & 432.33 & 870.08 & Inc & Core log. \\
\hline
\end{tabular}

Borehole: SD-12

Area: USW

Q Status: Q

\begin{tabular}{|c|c|c|c|}
\hline Northing & Easting & Elevation & Total depth \\
\hline 232244.36 & 171177.39 & 1323.69 & 609.60 \\
\hline
\end{tabular}

\begin{tabular}{|c|c|c|c|c|c|c|}
\hline $\begin{array}{l}\mathrm{T} / \mathrm{A} \\
\text { Un }\end{array}$ & & Lith. Unit & Depth & Elevation & Thickness & Comments \\
\hline 1 & & - & 98.91 & 1224.79 & 93.08 & Core log. \\
\hline \multirow{5}{*}{\multicolumn{2}{|c|}{$\begin{array}{l}\mathbf{R} \\
\mathbf{H} \\
\mathbf{H}\end{array}$}} & & 192.02 & 1131.71 & 197.49 & Geophysical log/lithophysal cavity estimate pick. \\
\hline & & Tptpull & 192.02 & 1131.71 & 10.28 & \\
\hline & & Tptpmn & 202.30 & 1121.43 & 37.54 & Core log. \\
\hline & & Tptpll & 239.85 & 1083.89 & $77.4 \overline{4}$ & Core log. \\
\hline & & Tptpin & 317.30 & $\overline{1006.45}$ & 72.23 & Core log. \\
\hline 3 & & - & 389.56 & 934.22 & 9.11 & Core log. \\
\hline \multicolumn{2}{|c|}{ CHn } & - & 398.68 & 925.10 & Inc & Core log. \\
\hline
\end{tabular}


Borehole: UZ-1

Area: USW

Q Status: Non-Q

\begin{tabular}{|c|c|c|c|}
\hline Northing & Easting & Elevation & Total depth \\
\hline 235084.87 & 170755.30 & 1349.07 & 387.10 \\
\hline
\end{tabular}

\begin{tabular}{|c|c|c|c|c|c|}
\hline $\begin{array}{l}T / 2 \\
\text { T }\end{array}$ & Lith. Unit & Depth & Elevation & Thickness & Comments \\
\hline 1 & - & 86.30 & 1262.77 & 92.01 & Cuttings log. \\
\hline \multirow{5}{*}{$\begin{array}{l}\mathbf{R} \\
\mathbf{H} \\
\mathbf{H}\end{array}$} & & 178.31 & 1170.76 & Inc & Geophysical log pick. \\
\hline & Tptpull & 178.31 & 1170.76 & 44.19 & \\
\hline & Tptpmn & 222.50 & 1126.57 & 30.48 & $\begin{array}{l}\text { Cuttings log. Discord with UZ-14 (difference }= \\
4.36 \mathrm{~m} \text { ). Did not use. }\end{array}$ \\
\hline & Tptpll & 252.98 & 1096.09 & 118.88 & Cuttings log. Did not use. \\
\hline & Tptpln & 371.86 & 977.21 & Inc & $\begin{array}{l}\text { Cuttings log. Bottom in Tptpln. Discord with UZ- } \\
14 \text { (difference }=24.79 \mathrm{~m} \text { ). Did not use. }\end{array}$ \\
\hline
\end{tabular}

Borehole: UZ-5

Area: USW

Q Status: Non-Q

Northing

234266.54

Easting

Elevation

1204.45

Total depth

111.25

\begin{tabular}{|c|c|c|c|c|c|}
\hline $\begin{array}{c}\text { T/M } \\
\text { Unit }\end{array}$ & Lith. Unit & Depth & Elevation & Thickness & Comments \\
\hline 1 & - & 107.90 & 1096.55 & Inc & Core log. Bottom in TSw1. \\
\hline
\end{tabular}

Borehole: UZ-6

Area: USW

Northing

231566.01

Easting

Elevation

1500.99

Q Status: Non-Q

\begin{tabular}{|c|}
\hline Total depth \\
\hline 575.16
\end{tabular}

\begin{tabular}{|c|c|c|c|c|c|}
\hline $\begin{array}{l}\text { T/M } \\
\text { Unit }\end{array}$ & Lith. Unit & Depth & Elevation & Thickness & Comments \\
\hline 1 & - & 147.41 & 1353.58 & 62.90 & Cuttings log. \\
\hline \multirow{5}{*}{$\begin{array}{l}\mathbf{R} \\
\mathbf{H} \\
\mathbf{H}\end{array}$} & & 210.31 & 1290.68 & 199.20 & Geophysical log pick. Questionable \\
\hline & Tptpull & 210.31 & 1290.68 & 11.30 & \\
\hline & Tptpmn & 221.61 & 1279.38 & 56.40 & Cuttings log. \\
\hline & Tptpll & 278.01 & 1222.99 & 83.51 & Cuttings log. Poor geophysical log. \\
\hline & Tptpln & 361.52 & 1139.48 & 48.00 & Cuttings log. Poor geophysical log. \\
\hline 3 & & 409.52 & 1091.48 & 11.10 & Cuttings log. \\
\hline CHn & - & 420.62 & 1080.38 & Inc & Curtings log. \\
\hline
\end{tabular}

Borehole: UZ-7a

Area: USW

\begin{tabular}{|c|c|c|c|}
\hline Northing & Easting & Elevation & Total depth \\
\hline 231859.15 & 171379.85 & 1288.78 & 480.06 \\
\hline
\end{tabular}

\begin{tabular}{|c|c|c|c|c|c|}
\hline $\begin{array}{l}\text { T/M } \\
\text { Unit }\end{array}$ & Lith. Unit & Depth & Elevation & Thickness & Comments \\
\hline 1 & - & 74.37 & 1214.42 & Inc & Core log. Poor geophysical log. \\
\hline & & - & - & Inc & Poor geophysical log - could not identify. \\
\hline $\mathbf{H}$ & Tptpull & $\frac{-}{1450}$ & 1142 & $\begin{array}{ll}\text { Inc } \\
3821\end{array}$ & Car- \\
\hline $\mathbf{H}$ & Tptpll & $\frac{184.34}{184.16}$ & 1104.65 & $\frac{38.21}{\operatorname{lnc}}$ & $\begin{array}{l}\text { Core log. Poor geophysical log. } \\
\text { Core log. Poor geophysical log. Bottom in TptpI }\end{array}$ \\
\hline
\end{tabular}


Title: Determination of Available Volume for Repository Siting

Borehole: UZ-14

Northing

235095.23

\begin{tabular}{|c|c|c|}
\hline & Area: USW & Q Status: Q \\
\hline Easting & Elevation & Total depth \\
\hline 170731.15 & 1348.86 & $6 \overline{77.75}$ \\
\hline
\end{tabular}

\begin{tabular}{|c|c|c|c|c|c|}
\hline $\begin{array}{l}\mathrm{T} / \mathrm{M} \\
\text { Unit }\end{array}$ & Lith. Unit & Depth & Elevation & Thickness & Comments \\
\hline 1 & - & 86.11 & 1262.75 & Inc & Core log. Poor geophysical log. \\
\hline \multirow{5}{*}{$\begin{array}{l}\mathbf{R} \\
\mathbf{H} \\
\mathbf{H}\end{array}$} & & & & Inc & Poor geophysical log - could not identify. \\
\hline & Tptpull & - & - & Inc & \\
\hline & Tptpmn & 217.93 & 1130.93 & 34.44 & Core log. Poor geophysical log. \\
\hline & Tptpll & 252.37 & 1096.49 & 94.49 & Core log. Poor geophysical log. \\
\hline & Tptpln & 346.86 & 1002.00 & 43.01 & Core log. Poor geophysical log. \\
\hline 3 & & 389.87 & 958.99 & 24.05 & Core log. \\
\hline CHn & - & 413.92 & 934.94 & Inc & Core log. \\
\hline
\end{tabular}

Borehole: UZ-16

Area: USW

Q Status: Non-Q

\begin{tabular}{|c|c|c|c|}
\hline Northing & Easting & Elevation & Total depth \\
\hline 231811.17 & 172168.38 & 1219.40 & 513.95 \\
\hline
\end{tabular}

\begin{tabular}{|c|c|c|c|c|c|}
\hline $\begin{array}{l}\text { T/M } \\
\text { Unit }\end{array}$ & Lith. Unit & Depth & Elevation & Thickness & Comments \\
\hline 1 & - & 70.19 & 1149.21 & 77.64 & Core log. \\
\hline \multirow{5}{*}{$\begin{array}{l}\mathbf{R} \\
\mathbf{H} \\
\mathbf{H}\end{array}$} & & -147.83 & 1071.57 & 190.87 & Geophysical log pick. \\
\hline & Tptpull & 147.83 & 1071.57 & 19.51 & \\
\hline & Tptpmn & 167.34 & 1052.06 & 42.97 & Core log. \\
\hline & Tptpll & 210.31 & 1009.09 & 68.58 & Core log. \\
\hline & Tptpln & 278.89 & 940.51 & 59.81 & Core log. \\
\hline $\mathbf{3}$ & - & 338.70 & 880.70 & 16.44 & Core log. \\
\hline CHn & & 355.14 & 864.26 & Inc & Core $\log$ (no depth). Geophysical log pick. \\
\hline
\end{tabular}

Borehole: UZN-31

Area: USW Q Status: Non-Q

\begin{tabular}{|c|c|c|c|}
\hline Northing & Easting & Elevation & Total depth \\
\hline 232942.07 & 171526.77 & 1265.47 & 58.86 \\
\hline
\end{tabular}

\begin{tabular}{|c|c|c|c|c|c|}
\hline $\begin{array}{c}\text { T/M } \\
\text { Unit }\end{array}$ & Lith. Unit & Depth & Elevation & Thickness & Comments \\
\hline 1 & - & 55.23 & 1210.24 & Inc & Core log. No geophysical log. Bottom in TSwl. \\
\hline
\end{tabular}

Borehole: UZN-32

\begin{tabular}{|c|c|c|c|c|c|}
\hline $\begin{array}{c}\text { T/M } \\
\text { Unit }\end{array}$ & Lith. Unit & Depth & Elevation & Thickness & Comments \\
\hline 1 & - & 60.77 & 1206.03 & Inc & Core log. No geophysical log. Bottom in TSw1. \\
\hline
\end{tabular}


Title: Determination of Available Volume for Repository Siting

Borehole: UZN-37

Area: USW

Northing

233933.73

\begin{tabular}{|c|c|}
\hline Easting \\
\hline 171819.88
\end{tabular}

Elevation

Q Status: Non-Q 1256.12

Total depth

82.70

\begin{tabular}{|c|c|c|c|c|c|}
\hline $\begin{array}{l}\text { T/M } \\
\text { Unit }\end{array}$ & Lith. Unit & Depth & Elevation & Thickness & Comments \\
\hline 1 & - & 78.24 & 1177.88 & Inc & Core log. No geophysical log. Bottom in TSw1. \\
\hline
\end{tabular}

Borehole: UZN-55

Area: USW

Q Status: Non-Q

\begin{tabular}{|c|c|c|c|}
\hline Northing & Easting & Elevation & Total depth \\
\hline 231801.28 & 171982.88 & 1240.72 & 78.15 \\
\hline
\end{tabular}

\begin{tabular}{|c|c|c|c|c|c|}
\hline $\begin{array}{c}\text { T/M } \\
\text { Unit }\end{array}$ & Lith. Unit & Depth & Elevation & Thickness & Comments \\
\hline 1 & - & 74.31 & 1166.41 & Inc & Core log. No geophysical log. Bottom in TSw 1. \\
\hline
\end{tabular}

Borehole: WT-2

\begin{tabular}{|c|c|c|c|}
\hline \multicolumn{3}{|c|}{ Area: USW } & Q Status: Non-Q \\
\hline Northing & Easting & Elevation & Total depth \\
\hline 231849.64 & 171274.44 & 1300.96 & 627.89 \\
\hline
\end{tabular}

\begin{tabular}{|c|c|c|c|c|c|}
\hline $\begin{array}{l}\text { T/M } \\
\text { Unit }\end{array}$ & Lith. Unit & - Depth & Elevation & Thickness & Comments \\
\hline 1 & - & 85.34 & 1215.64 & 79.21 & Cuttings log. \\
\hline \multirow{5}{*}{$\begin{array}{l}\mathbf{R} \\
\mathbf{H} \\
\mathbf{H}\end{array}$} & & 164.59 & 1136.43 & 194.45 & Geophysical log pick. \\
\hline & Tptpull & 164.59 & 1136.43 & 16.75 & \\
\hline & Tptpmn & 181.36 & 1119.68 & 37.13 & Cuttings log. \\
\hline & Tptpll & 218.54 & 1082.56 & 90.67 & Cuttings log. \\
\hline & Tptpln & 309.38 & 991.88 & 49.90 & Cuttings log. \\
\hline 3 & - & 359.36 & 941.98 & 13.39 & Cuttings log. \\
\hline CHn & - & 372.77 & 928.59 & Inc & Cuttings log. \\
\hline
\end{tabular}

Borehole: WT-4

Area: USW

Q Status: Non-Q

\begin{tabular}{|c|c|c|c|}
\hline Northing & Easting & Elevation & Total depth \\
\hline 234242.38 & 173138.64 & 1167.11 & 481.58 \\
\hline
\end{tabular}

\begin{tabular}{|c|c|c|c|c|c|}
\hline $\begin{array}{l}\text { T/M } \\
\text { Unit }\end{array}$ & Lith. Unit & Depth & Elevation & Thickness & Comments \\
\hline 1 & - & 138.99 & 1028.15 & 70.39 & Cuttings log. \\
\hline \multirow{6}{*}{$\begin{array}{l}\mathbf{R} \\
\mathbf{H} \\
\mathbf{H}\end{array}$} & & 209.40 & 957.76 & 127.19 & Geophysical log pick. \\
\hline & Tptpull & 209.40 & 957.76 & 13.09 & \\
\hline & Tptpmn & 222.50 & 944.67 & 21.29 & Cuttings $\log (214.88)$. Geophysical log pick. \\
\hline & Tptpll & 243.81 & 923.38 & 51.80 & Cuttings $\log (240.18)$. Geophysical log pick. \\
\hline & Tptpln & 295.70 & 871.57 & 41.01 & Cuttings log (no depth). Geophysical log pick \\
\hline & - & 336.79 & 830.56 & 6.69 & Cuttings $\log (332.54)$. Geophysical log pick. \\
\hline CHn & - & 343.49 & 823.88 & Inc & Cuttings $\log (341.99)$. Geophysical log pick. \\
\hline
\end{tabular}


Borehole: WT-18

\begin{tabular}{|r|}
\hline Northing \\
\hline 235051.73 \\
\hline
\end{tabular}

$\frac{\text { Easting }}{172167.80}$

Area: USW 1335.94
Q Status: Non-Q

$\frac{\text { Total depth }}{622.71}$

\begin{tabular}{|c|c|c|c|c|c|c|}
\hline \multicolumn{2}{|c|}{$\begin{array}{l}\mathbf{T} / \mathbf{M} \\
\text { Unit }\end{array}$} & Lith. Unit & Depth & Elevation & Thickness & Comments \\
\hline \multicolumn{2}{|c|}{1} & - & 213.66 & 1122.29 & 91.32 & Cuttings log. \\
\hline \multirow{5}{*}{$\begin{array}{l}\mathbf{R} \\
\mathbf{H} \\
\mathbf{H}\end{array}$} & & & 305.00 & 1030.97 & 154.59 & Geophysical log pick. Questionable. \\
\hline & 1 & Tptpull & 305.00 & 1030.97 & 22.05 & \\
\hline & \multirow{3}{*}{2} & Tptpmn & 327.05 & 1008.92 & 14.33 & Cuttings log. \\
\hline & & Tptpll & 341.38 & 994.59 & 70.09 & Cuttings log. \\
\hline & & Tptpln & 411.48 & 924.50 & 48.13 & Cuttings $\log (456.28)$. Geophysical log pick. \\
\hline 3 & & - & 459.62 & 876.37 & 15.53 & Cuttings $\log (457.50)$. Geophysical log pick. \\
\hline \multicolumn{2}{|c|}{ CHn } & - & 475.79 & 860.21 & Inc & Cuttings log. \\
\hline
\end{tabular}

Borehole: $\mathrm{a}-\mathbf{4}$

Area: USW

Q Status: Non-Q

\begin{tabular}{|c|c|c|c|}
\hline Northing & Easting & Elevation & Total depth \\
\hline 234077.84 & 172051.00 & 1249.90 & 152.40 \\
\hline
\end{tabular}

\begin{tabular}{|c|c|c|c|c|c|}
\hline $\begin{array}{c}\text { T/M } \\
\text { Unit }\end{array}$ & Lith. Unit & Depth & Elevation & Thickness & Comments \\
\hline 1 & - & 96.56 & 1153.34 & Inc & Core log. No geophysical log. Bottom in TSw1. \\
\hline
\end{tabular}

Borehole: a-5

Area: USW

Q Status: Non-Q

\begin{tabular}{|c|c|c|c|}
\hline Northing & Easting & Elevation & Total depth \\
\hline 233768.30 & 172137.36 & 1236.42 & 148.44 \\
\hline
\end{tabular}

\begin{tabular}{|c|c|c|c|c|c|}
\hline $\begin{array}{c}\text { T/M } \\
\text { Unit }\end{array}$ & Lith. Unit & Depth & Elevation & Thickness & Comments \\
\hline 1 & - & 84.43 & 1151.99 & Inc & Core log. Bottom in TSwl. \\
\hline
\end{tabular}

Borehole: a-6

Area: USW

Northing

233446.16

\begin{tabular}{|c|c|} 
& Easting \\
\hline & 172059.82
\end{tabular}

1235.32

Q Status: Non-Q

\begin{tabular}{|c|c|c|c|c|c|}
\hline $\begin{array}{c}\text { T/M } \\
\text { Unit }\end{array}$ & Lith. Unit & Depth & Elevation & Thickness & Comments \\
\hline 1 & - & 73.67 & 1161.65 & Inc & Core log. Bottom in TSwl. \\
\hline
\end{tabular}

Borehole: a-7 (angle hole)

\begin{tabular}{|r|}
\hline Northing \\
\hline 233553.01 \\
\hline
\end{tabular}

Easting
172354.74

Area: USW

Q Status: Non-Q

\begin{tabular}{|c|c|c|c|c|c|}
\hline $\begin{array}{c}\text { T/M } \\
\text { Unit }\end{array}$ & Lith. Unit & Depth & Elevation & Thickness & Comments \\
\hline I & - & 92.81 & 1137.48 & Inc & Core log. Bottom in TSwl. \\
\hline
\end{tabular}


Borehole: b-1

Area: USW

Q Status: Non-Q

\begin{tabular}{|c|c|c|c|}
\hline Northing & Easting & Elevation & Total depth \\
\hline 233246.18 & 172643.72 & 1200.61 & 1219.81 \\
\hline
\end{tabular}

\begin{tabular}{|c|c|c|c|c|c|}
\hline $\begin{array}{l}\text { T/M } \\
\text { Unit }\end{array}$ & Lith. Unit & Depth & Elevation & Thickness & Comments \\
\hline 1 & - & 83.80 & 1116.81 & 108.79 & Cuttings log. No geophysical log. \\
\hline \multirow{5}{*}{$\begin{array}{l}\mathbf{R} \\
\mathbf{H} \\
\mathbf{H}\end{array}$} & & 192.63 & 1008.03 & $\operatorname{lnc}$ & Geophysical log pick. \\
\hline & Tptpull & 192.63 & 1008.03 & 17.36 & \\
\hline & Tptpmn & 210.01 & 990.66 & 22.84 & Cuttings log. \\
\hline & Tptpll & 232.87 & 967.82 & 106.92 & Cuttings log. \\
\hline & Tptpln & 339.90 & 860.90 & Inc & $\begin{array}{l}\text { Cuttings } \log (298.09) \text {. Geophysical log pick. } \\
\text { Faulted. }\end{array}$ \\
\hline \multirow{2}{*}{$\frac{3}{\mathrm{CHn}}$} & - & 394.69 & 806.14 & Inc & Cuttings log. Faulted. \\
\hline & - & 405.38 & 795.45 & Inc & Cuttings log. \\
\hline
\end{tabular}

ESF (ESF Tunnel Mapping)

\begin{tabular}{|c|c|c|c|c|}
\hline $\begin{array}{l}\mathbf{T} / \mathbf{M} \\
\text { Unit }\end{array}$ & Lith. Unit & Station & Elevation & Comments \\
\hline 1 & - & $10+76.00$ & 1106.25 & ESF tunnel mapping. \\
\hline 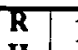 & Tptpull & $23+25.00$ & 1079.11 & Estimated from ESF tunnel mapping \\
\hline $\begin{array}{l}\mathbf{H} \\
\mathbf{H}\end{array}$ & Tptpmn & $27+20.00$ & 1070.54 & ESF tunnel mapping. \\
\hline
\end{tabular}




\section{Attachment III \\ AVERAGE GROUNDWATER LEVEL DATA LISTING FOR THE DESIGN MODEL}

Groundwater depth data is taken from the RIB (Reference 5.4), and is based on 1993 water-level measurements. Measurements from one borehole, G2, were taken from the Yucca Mountain Project Stratigraphic Compendium (Reference 5.45) because it was not included in the RIB. This data are all qualified except for the borehole G-2 data.

\begin{tabular}{|c|c|c|c|c|c|c|c|c|}
\hline \multirow[b]{2}{*}{ Borehole } & \multirow[b]{2}{*}{ Area } & \multirow{2}{*}{$\begin{array}{l}\text { Northing } \\
(\mathrm{m})^{1}\end{array}$} & \multirow{2}{*}{$\begin{array}{l}\text { Easting } \\
(\mathbf{m})^{1}\end{array}$} & \multirow{2}{*}{$\begin{array}{l}\text { Collar } \\
\text { Elev. } \\
(\mathrm{m})^{i}\end{array}$} & \multirow[b]{2}{*}{ Samples } & \multicolumn{3}{|c|}{ Elevation (m) } \\
\hline & & & & & & $\begin{array}{l}\text { Highest } \\
\text { Level }\end{array}$ & $\begin{array}{c}\text { Lowest } \\
\text { Level }\end{array}$ & Average \\
\hline $\mathrm{G}-2^{2}$ & USW & 237385.61 & 170841.58 & 1553.99 & 1 & $\cdot$ & - & 1029.00 \\
\hline$G-3^{3}$ & USW $\bar{W}$ & $229447 . \overline{30}$ & 170225.66 & 1480.26 & 8590 & 730.90 & 730.37 & 730.54 \\
\hline $\mathrm{H}-\mathrm{I}$ & USW & 234773.52 & 171415.85 & 1302.84 & 8751 & 731.11 & 730.72 & 730.96 \\
\hline $\mathrm{H}-3$ & USW & 230594.03 & 170216.06 & 1483.28 & 8749 & 731.41 & 731.06 & $73 \overline{1.20}$ \\
\hline $\mathrm{H}-4$ & USW & 232148.98 & 171880.11 & 1248.61 & 8739 & 730.57 & 730.29 & 730.46 \\
\hline $\mathrm{H}-5$ & USW & 233670.08 & 170355.28 & 1478.83 & 8073 & 775.89 & 775.45 & 775.55 \\
\hline H-6 & USW & $2 3 2 \longdiv { 2 6 5 3 . 4 9 }$ & 168882.04 & 1301.68 & 8635 & 776.23 & 775.94 & 776.03 \\
\hline WT-2 & USW & $2 3 \longdiv { 1 8 4 9 . 6 4 }$ & 171274.44 & 1300.96 & 5848 & 730.87 & 730.39 & 730.70 \\
\hline WT-4 & UE25 & 234242.38 & 173138.64 & 1167.11 & 8 & 730.44 & 730.30 & 730.37 \\
\hline WT- $6^{4}$ & UE25 & 237919.50 & 172066.89 & 1312.74 & 8 & 1034.19 & 1034.07 & $1034 . \overline{14}$ \\
\hline WT-7 & USW & 230297.66 & 168826.17 & 1196.83 & 6 & $77 \overline{5.89}$ & 775.80 & 775.86 \\
\hline WT- $16^{4}$ & UE25 & 236043.11 & $173856 . \overline{36}$ & 1210.48 & 8 & 738.49 & 738.11 & 738.22 \\
\hline WT-18 & UE25 & 235051.73 & 172167.80 & 1335.94 & 8 & 731.23 & 730.62 & 730.72 \\
\hline$b-1$ & UE25 & 233246.18 & 172643.72 & 1200.61 & 277 & 730.81 & 730.57 & 730.68 \\
\hline$c-2$ & UE25 & 230687.40 & 173624.24 & 1132.06 & 1 & - & - & 729.98 \\
\hline$c-3$ & UE25 & 230706.06 & 173600.15 & 1132.09 & 1 & - & - & 730.21 \\
\hline
\end{tabular}

'Coordinates from Technical Data Base (02/06/96 listing).

${ }^{2}$ Water level data from Yucca Mountain Project Stratigraphic Compendium (Reference 5.45).

${ }^{3}$ Borehole G-3 is located $27.36 \mathrm{~m}$ north and $5.54 \mathrm{~m}$ west of borehole GU-3.

${ }^{4}$ WT -6 and WT- 16 were used in construction of the surface but are not shown in Figure 4 (covered by Legend). 


\section{Attachment IV \\ LIST OF BOREHOLE DATA SUBSETS INCLUDED \\ IN THE DESIGN MODEL}

These database files are binary files that are specific to the LYNX system. They are contained in the directory YMP.MO3Q/dholes (Attachment VII). Each data subset has two files - 'dhx' and ' $d h x . I N D X$ ', where ' $x$ ' is the subset number. The data is contained in the ' $d h x$ ' file and the corresponding utility index file is named ' $d h x . I N D X$ '.

\begin{tabular}{|c|c|}
\hline Subset & Description \\
\hline 0 & Not used \\
\hline 1 & Not used \\
\hline 2 & Not used \\
\hline 3 & Not used \\
\hline 4 & $\begin{array}{l}\text { YMP.MO3Q outcrop mapping database (Reference } 5.47 \text { ) } \\
\text { Includes the following zone contacts: } \\
\begin{aligned} \text { CPU1 } & =\text { Tpcpv } 2 / 1-\text { Tpbt4 contact }(\text { within PTn thermal/mechanical unit) } \\
\text { TRV2 } & =\text { Tptrv1 }- \text { Tptrv2/3 contact (PTn }- \text { TSwl contact) } \\
\text { TPUL } & =\text { Tptrl/pul }- \text { Tptpmn contact (TSw }- \text { TSw2 contact) }\end{aligned}\end{array}$ \\
\hline 5 & Not used \\
\hline 6 & Not used \\
\hline 7 & $\begin{array}{l}\text { YMP.MO3Q borehole database for modeling (See Attachment II) } \\
\text { Includes the following stratigraphic units: } \\
\text { +PTn = PTn thermal/mechanical unit and above } \\
\text { TSw1 = TSw1 thermal/mechanical unit } \\
\text { TSw2 = TSw2 thermal/mechanical unit } \\
\text { Tptpull = informal lower part of Tptpul upper lithophysal zone (top is top of Repository Host } \\
\text { Horizon) } \\
\text { Tptpmn = middle nonlithophysal zone } \\
\text { Tptpll = lower lithophysal zone } \\
\text { Tptpln }=\text { lower nonlithophysal zone (bottom is bottom of Repository Host Horizon) } \\
\text { TSw3 }=\text { TSw3 thermal/mechanical unit } \\
\text {-CHn }=\text { CHn thermal/mechanical unit and below }\end{array}$ \\
\hline 8 & $\begin{array}{l}\text { YMP.MO3Q ESF mapping database for modeling (Reference 5.44) } \\
\text { Includes following 'boreholes' (right rib spring line): } \\
\text { ESF = Sta. } 4+00 \text { to } 28+00\end{array}$ \\
\hline 9 & YMP.MO3Q groundwater database for modeling (See Attachment III) \\
\hline
\end{tabular}




\section{Attachment $V$ \\ LIST OF MAPS INCLUDED IN THE DESIGN MODEL}

In the LYNX system, map files are contained in the directory YMP.MO3Q/overlays (Attachment VII). Maps in the Design Model are named usually according to a two-part code. The first part identifies the type of map while the second part is the modifier. For example, under topography, the topographic map for area B3 would be identified as T5-B3. The 'T5-' identifies the type of map and the ' $\mathrm{B} 3$ ' identifies the area. Other files that may be in the directory are index files named '*.INDX' and are created for each map file when it is accessed by LYNX.

\begin{tabular}{|c|c|}
\hline Map Name & Description \\
\hline \multicolumn{2}{|c|}{$\begin{array}{l}\text { Topography: } \\
\left({ }^{*} \mathrm{~A} 1=\text { area } \mathrm{A} 1,{ }^{*} \mathrm{~A} 2=\text { area } \mathrm{A} 2,{ }^{*} \mathrm{~A} 3=\text { area } \mathrm{A} 3,{ }^{*} \mathrm{~A} 4=\text { area } \mathrm{A} 4,{ }^{*} \mathrm{~A} 5=\text { area } \mathrm{A} 5,{ }^{*} \mathrm{~B} 1=\text { area } \mathrm{B} 1,{ }^{*} \mathrm{~B} 2=\text { area } \mathrm{B} 2,\right. \\
{ }^{*} \mathrm{~B} 3=\text { area } \mathrm{B} 3,{ }^{*} \mathrm{~B} 4=\text { area } \mathrm{B} 4,{ }^{*} \mathrm{~B} 5=\text { area } \mathrm{B} 5,{ }^{*} \mathrm{C} 1=\text { area } \mathrm{C} 1,{ }^{*} \mathrm{C} 2=\text { area } \mathrm{C} 2,{ }^{*} \mathrm{C} 3=\text { area } \mathrm{C} 3,{ }^{*} \mathrm{C} 4=\text { area } \mathrm{C} 4,{ }^{*} \mathrm{C} 5=\text { area } \\
\left.\mathrm{C} 5,{ }^{*} \mathrm{D} 1=\text { area } \mathrm{D} 1,{ }^{*} \mathrm{D} 2=\text { area } \mathrm{D} 2,{ }^{*} \mathrm{D} 3=\text { area } \mathrm{D} 3,{ }^{*} \mathrm{D} 4=\text { area } \mathrm{D} 4,{ }^{*} \mathrm{D} 5=\text { area } \mathrm{D} 5\right)\end{array}$} \\
\hline T5-* (20 maps) & Topography, 5-m contour interval \\
\hline T5-A1 & N236000-238500, E172000-174000 \\
\hline $\mathrm{T} 5-\mathrm{A} 2$ & $\mathrm{~N} 234000-236000, \mathrm{E} 172000-174000$ \\
\hline T5-A3 & $\mathrm{N} 232000-234000, \mathrm{E} 172000-174000$ \\
\hline T5-A4 & N230000-232000, E172000-174000 \\
\hline T5-A5 & $\mathrm{N} 227550-230000, \mathrm{E} 172000-174000$ \\
\hline T5-B1 & $\mathrm{N} 236000-238500, \mathrm{E} 170000-172000$ \\
\hline T5-B2 & $\mathrm{N} 234000-236000, \mathrm{E} 170000-172000$ \\
\hline T5-B3 & $\mathrm{N} 232000-234000, \mathrm{E} 170000-172000$ \\
\hline T5-B4 & $\mathrm{N} 230000-232000, \mathrm{E} 170000-172000$ \\
\hline T5-B5 & N227550-230000, E170000-172000 \\
\hline $\mathrm{T} 5-\mathrm{Cl}$ & $\mathrm{N} 236000-238500$, E168000-170000 \\
\hline $\mathrm{T} 5-\mathrm{C} 2$ & $\mathrm{~N} 234000-236000$, E168000-170000 \\
\hline T5-C3 & $\mathrm{N} 232000-234000, \mathrm{E} 168000-170000$ \\
\hline T5-C4 & $\mathrm{N} 230000-232000, \mathrm{E} 168000-170000$ \\
\hline T5-C5 & N227550-230000, E168000-170000 \\
\hline T5-D1 & N236000-238500, E167050-168000 \\
\hline T5-D2 & $\mathrm{N} 234000-236000$, E167050-168000 \\
\hline T5-D3 & $\mathrm{N} 232000-234000, \mathrm{E} 167050-168000$ \\
\hline T5-D4 & $\mathrm{N} 230000-232000, \mathrm{E} 167050-168000$ \\
\hline T5-D5 & N227550-230000, E167050-168000 \\
\hline
\end{tabular}


Title: Determination of Available Volume for Repository Siting

\begin{tabular}{|c|c|}
\hline B-* (20 maps) & $200-\mathrm{m}$ cover surface contours with $20-\mathrm{m}$ contour interval \\
\hline B-Al & N236000-238500, E172000-174000 \\
\hline B-A2 & $\mathrm{N} 234000-236000, \mathrm{E} 172000-174000$ \\
\hline B-A3 & N232000-234000, E172000-174000 \\
\hline B-A4 & $\mathrm{N} 230000-232000, \mathrm{E} 172000-174000$ \\
\hline B-A5 & $\mathrm{N} 227550-230000, \mathrm{E} 172000-174000$ \\
\hline B-B1 & $\mathrm{N} 236000-238500, \mathrm{E} 170000-172000$ \\
\hline B-B2 & $\mathrm{N} 234000-236000, \mathrm{E} 170000-172000$ \\
\hline B-B3 & N232000-234000, E170000-172000 \\
\hline B-B4 & N230000-232000, E170000-172000 \\
\hline B-B5 & $\mathrm{N} 227550-230000, \mathrm{E} 170000-172000$ \\
\hline $\mathrm{B}-\mathrm{Cl}$ & $\mathrm{N} 236000-238500, \mathrm{E} 168000-170000$ \\
\hline B-C2 & $\mathrm{N} 234000-236000, \mathrm{E} 168000-170000$ \\
\hline B-C3 & $\mathrm{N} 232000-234000, \mathrm{E} 168000-170000$ \\
\hline B-C4 & $\mathrm{N} 230000-232000, \mathrm{E} 168000-170000$ \\
\hline B-C5 & $\mathrm{N} 227550-230000, \mathrm{E} 168000-170000$ \\
\hline B-D1 & $\mathrm{N} 236000-238500, \mathrm{E} 167050-168000$ \\
\hline B-D2 & $\mathrm{N} 234000-236000, \mathrm{E} 167050-168000$ \\
\hline B-D3 & $\mathrm{N} 232000-234000, \mathrm{E} 167050-168000$ \\
\hline B-D4 & $\mathrm{N} 230000-232000, \mathrm{E} 167050-168000$ \\
\hline B-D5 & $\mathrm{N} 227550-230000, \mathrm{E} 167050-168000$ \\
\hline B3-* (15 maps) & $300-\mathrm{m}$ cover surface contours with $20-\mathrm{m}$ contour interval \\
\hline B3-A1 & $\mathrm{N} 236000-238500, \mathrm{E} 172000-174000$ \\
\hline B3-A2 & $\mathrm{N} 234000-236000, \mathrm{E} 172000-174000$ \\
\hline B3-A3 & $\mathrm{N} 232000-234000, \mathrm{E} 172000-174000$ \\
\hline B3-B1 & $\mathrm{N} 236000-238500, \mathrm{E} 170000-172000$ \\
\hline B3-B2 & $\mathrm{N} 234000-236000, \mathrm{E} 170000-172000$ \\
\hline B3-B3 & N232000-234000, E170000-172000 \\
\hline B3-B4 & $\mathrm{N} 230000-232000, \mathrm{E} 170000-172000$ \\
\hline B3-B5 & $\mathrm{N} 227550-230000, \mathrm{E} 170000-172000$ \\
\hline $\mathrm{B} 3-\mathrm{Cl}$ & $\mathrm{N} 236000-238500$, E $168000-170000$ \\
\hline B3-C2 & $\mathrm{N} 234000-236000, \mathrm{E} 168000-170000$ \\
\hline B3-C3 & $\mathrm{N} 232000-234000, \mathrm{E} 168000-170000$ \\
\hline B3-C4 & $\mathrm{N} 230000-232000, \mathrm{E} 168000-170000$ \\
\hline B3-D1 & $\mathrm{N} 236000-238500$, E167050-168000 \\
\hline B3-D2 & $\mathrm{N} 234000-236000, \mathrm{E} 167050-168000$ \\
\hline B3-D3 & $\mathrm{N} 232000-234000, \mathrm{E} 167050-168000$ \\
\hline
\end{tabular}

Stratigraphy Top Structure Modeling:

( $\mathrm{p}$ =structure data points, ${ }^{*} \mathrm{o}=$ outcrop data points, ${ }^{*} \mathrm{c}=$ structure contours, ${ }_{\mathrm{f}}=$ fault traces on top structure, ${ }^{*} \mathrm{~b}=$ boundary)

\begin{tabular}{|l|l|}
\hline TSw1* & TSw1 unit top structure \\
\hline RHH $^{*}$ & Repository Host Horizon top structure \\
\hline Tptpmn* & Middle nonlithophysal zone top structure (top TSw2 unit) \\
\hline Tptpll & Lower lithophysal zone top structure \\
\hline Tptpln* & Lower nonlithophysal zone top structure (no Tptplno map) \\
\hline TSw3* & TSw3 unit top structure (no TSw3o map) \\
\hline $\mathrm{CHn}^{*}$ & CHn unit top structure (no CHno map) \\
\hline
\end{tabular}




\begin{tabular}{|c|c|}
\hline \multicolumn{2}{|c|}{$\begin{array}{l}\text { Stratigraphy Thickness Modeling: } \\
\left({ }^{*} p=\text { thickness data points, }{ }^{*} c=\text { thickness contours) }\right.\end{array}$} \\
\hline TSw $1 i^{*}$ & TSw1 unit thickness \\
\hline $\mathrm{RHHi}^{*}$ & Repository Host Horizon total thickness \\
\hline Tptulli* & $\begin{array}{l}\text { Thickness of lower part of upper lithophysal zone (Tptpul) below the top of the RHH, } \\
\text { informally called Tptpull }\end{array}$ \\
\hline Tptpmni* & Middle nonlithophysal zone thickness \\
\hline Tptplli* & Lower lithophysal zone thickness \\
\hline Tptplni* & Lower nonlithophysal zone thickness \\
\hline TSw3i* & TSw3 unit thickness \\
\hline \multicolumn{2}{|c|}{ Fault Modeling: } \\
\hline DAYf0996 & Central block faults from Reference 5.48 \\
\hline nfltolm & Solitario Canyon fault, main trace $\left(80^{\circ} \mathrm{W}\right.$ dip) \\
\hline nflt02m & Solitario Canyon fault, splay $\mathrm{A}\left(80^{\circ} \mathrm{W}\right.$ dip) \\
\hline nflt03m & Solitario Canyon fault, splay $\mathrm{B}\left(80^{\circ} \mathrm{W}\right.$ dip) \\
\hline nflt $04 \mathrm{~m}$ & Solitario Canyon fault, splay $\mathrm{C}\left(60^{\circ} \mathrm{W}\right.$ dip $)$ \\
\hline nflt05m & Solitario Canyon fault, splay $\mathrm{D}\left(80^{\circ} \mathrm{W}\right.$ dip $)$ \\
\hline nflt $06 \mathrm{~m}$ & Solitario Canyon fault, splay E ( $80^{\circ} \mathrm{W}$ dip) \\
\hline nflt07m & Pagany Wash fault (vertical) \\
\hline$\overline{\text { nflt } 08 m}$ & Drill Hole Wash fault, main trace (vertical) \\
\hline nflt $09 \mathrm{~m}$ & Drill Hole Wash fault, splay (vertical) \\
\hline nflt $10 m$ & Sundance fault (vertical) \\
\hline nflt llm & Ghost Dance fault ( $94^{\circ} \mathrm{W}$ dip) \\
\hline nflt $12 m$ & Abandoned Wash fault, main trace $\left(80^{\circ} \mathrm{W}\right.$ dip) \\
\hline nflt $13 m$ & Abandoned Wash fault, splay ( $80^{\circ} \mathrm{W}$ dip) \\
\hline nflt $14 \mathrm{~m}$ & Dune Wash fault, main trace $\left(80^{\circ} \mathrm{W}\right.$ dip $)$ \\
\hline nflt $15 \mathrm{~m}$ & Dune Wash fault, splay $\mathrm{A}\left(80^{\circ} \mathrm{W}\right.$ dip $)$ \\
\hline nflt $16 \mathrm{~m}$ & Dune Wash fault, splay B (80 $\mathrm{W}$ dip) \\
\hline nflt $17 \mathrm{~m}$ & Imbricate fault, trace $\mathrm{A}\left(80^{\circ} \mathrm{E}\right.$ dip $)$ \\
\hline nflt $18 \mathrm{~m}$ & Imbricate fault, trace $\mathrm{B}\left(80^{\circ} \mathrm{W}\right.$ dip $)$ \\
\hline nflt $19 m$ & Imbricate fault, trace $\mathrm{C}\left(80^{\circ} \mathrm{W}\right.$ dip $)$ \\
\hline $\mathrm{nfl} 20 \mathrm{~m}$ & Imbricate fault, trace $\mathrm{D}\left(80^{\circ} \mathrm{W}\right.$ dip $)$ \\
\hline nft $21 \mathrm{~m}$ & Imbricate fault, trace $\mathrm{E}\left(80^{\circ} \mathrm{E}\right.$ dip $)$ \\
\hline nflt $22 m$ & Imbricate fault, trace $\mathrm{F}\left(60^{\circ} \mathrm{E}\right.$ dip $)$ \\
\hline $\mathrm{nflt} 23 \mathrm{~m}$ & Imbricate fault, trace $\mathrm{G}\left(80^{\circ} \mathrm{W}\right.$ dip $)$ \\
\hline $\mathrm{nflt} 24 \mathrm{~m}$ & Imbricate fault, trace $\mathrm{H}\left(80^{\circ} \mathrm{W}\right.$ dip $)$ \\
\hline nflt $25 \mathrm{~m}$ & Imbricate fault, trace I $\left(80^{\circ} \mathrm{E}\right.$ dip $)$ \\
\hline nflt $26 \mathrm{~m}$ & Imbricate fault, trace $\mathrm{J}\left(80^{\circ} \mathrm{E}\right.$ dip $)$ \\
\hline $\mathrm{nfl} 2 \mathrm{2} 2 \mathrm{~m}$ & Sever Wash fault, main trace (vertical) \\
\hline nflt $28 \mathrm{~m}$ & Sever Wash fault, splay (vertical) \\
\hline $\mathrm{nflt} 29 \mathrm{~m}$ & Bow Ridge fault, main trace (vertical) \\
\hline $\mathrm{nflt30m}$ & Bow Ridge fault, splay (vertical) \\
\hline \multicolumn{2}{|c|}{ Stratigraphic Distance to Reference Repository Levels Modeling: } \\
\hline TSWIDURB & Upper repository crown level to top TSw1 (bottom PTn), contours \\
\hline TSwIDLRB & Lower repository expansion crown level to top TSw 1 (bottom PTn), contours \\
\hline RHH_DURB & Upper repository crown level to top RHH, contours \\
\hline RHH_DLRB & Lower repository expansion crown level to top RHH, contours \\
\hline TSw3DURB & Upper repository invert level to top TSw3, contours \\
\hline
\end{tabular}


Title: Determination of Available Volume for Repository Siting

\begin{tabular}{|c|c|}
\hline TSw3DLRB & Lower repository expansion invert level to top TSw3, contours \\
\hline \multicolumn{2}{|c|}{ Groundwater Modeling: } \\
\hline GWL_RIBp & Groundwater level data points (data listed in Attachment III) \\
\hline GWL_RIB & Groundwater level contours \\
\hline GWUBoff & Upper repository invert level to top of groundwater table \\
\hline GWLBoff & Lower repository expansion invert level to top of groundwater table \\
\hline
\end{tabular}

Repository Modeling:

\begin{tabular}{|c|c|}
\hline Rinv_Um & Upper repository block modeling plane at invert level with control points \\
\hline $\mathrm{R}+762 \_\mathrm{Um}$ & $\begin{array}{l}\text { Upper repository block modeling plane at crown level ( } 7.62 \mathrm{~m} \text { above invert level) } \\
\text { with control points }\end{array}$ \\
\hline Rinv_L & Lower repository expansion block modeling plane at invert level with control points \\
\hline $\mathrm{R}+762 \_\mathrm{L}$ & $\begin{array}{l}\text { Lower repository expansion block modeling plane at crown level }(7.62 \mathrm{~m} \text { above invert } \\
\text { level) with control points }\end{array}$ \\
\hline
\end{tabular}




\section{Attachment VI \\ LIST OF GEOLOGY AND ENGINEERING VOLUME MODELS INCLUDED IN THE DESIGN MODEL}

Volume models are contained in the directory YMP.MO3Q/3d (Attachment VII). The geology models are identified with the prefix ' $G$ ' and mining models are identified with the prefix ' $M$ '. The model name follows the prefix. Each model is comprised of components. Applicable components are identifed for each model. If 'auto name' appears as the component name, this means that the name is automatically assigned by the system and have numeric codes. Index files may also be in this directory and are identified by the suffix '.INDX'. These are generated by LYNX when the file is accessed.

\begin{tabular}{|c|c|c|}
\hline Volume Name & $\begin{array}{l}\text { Component } \\
\text { Name }\end{array}$ & Description \\
\hline \multicolumn{3}{|c|}{ Geology Models: } \\
\hline G.T-* & (auto name) & $\begin{array}{l}\text { Topography }\left({ }^{*} \mathrm{~A} 1=\text { area } \mathrm{A} 1,{ }^{*} \mathrm{~A} 2=\text { area } \mathrm{A} 2,{ }^{*} \mathrm{~A} 3=\text { area } \mathrm{A} 3,{ }^{*} \mathrm{~A} 4=\text { area } \mathrm{A} 4,\right. \\
{ }^{*} \mathrm{~A} 5=\text { area } \mathrm{A} 5,{ }^{*} \mathrm{~B} 1=\text { area } \mathrm{B} 1,{ }^{*} \mathrm{~B} 2=\text { area } \mathrm{B} 2,{ }^{*} \mathrm{~B} 3=\text { area } \mathrm{B} 3,{ }^{*} \mathrm{~B} 4=\text { area } \mathrm{B} 4, \\
{ }^{*} \mathrm{~B} 5=\text { area } \mathrm{B} 5,{ }^{*} \mathrm{C} 1=\text { area } \mathrm{C} 1,{ }^{*} \mathrm{C} 2=\text { area } \mathrm{C} 2,{ }^{*} \mathrm{C} 3=\text { area } \mathrm{C} 3,{ }^{*} \mathrm{C} 4=\text { area } \mathrm{C} 4, \\
{ }^{*} \mathrm{C} 5=\text { area } \mathrm{C} 5,{ }^{*} \mathrm{D} 1=\text { area } \mathrm{D} 1,{ }^{*} \mathrm{D} 2=\text { area } \mathrm{D} 2,{ }^{*} \mathrm{D} 3=\text { area } \mathrm{D} 3,{ }^{*} \mathrm{D} 4=\text { area } \mathrm{D} 4, \\
{ }^{* D 5}=\text { area D5) }\end{array}$ \\
\hline G.B-* & (auto name) & $\begin{array}{l}\text { 200-m overburden model }\left({ }^{*} \mathrm{~A} 1=\text { area } \mathrm{A} 1,{ }^{*} \mathrm{~A} 2=\text { area } \mathrm{A} 2,{ }^{*} \mathrm{~A} 3=\text { area } \mathrm{A} 3,\right. \\
{ }^{*} \mathrm{~A} 4=\text { area } \mathrm{A} 4,{ }^{*} \mathrm{~A} 5=\text { =area } \mathrm{A} 5,{ }^{*} \mathrm{~B} 1=\text { area } \mathrm{B} 1,{ }^{*} \mathrm{~B} 2=\text { area } \mathrm{B} 2,{ }^{*} \mathrm{~B} 3=\text { area } \mathrm{B} 3, \\
{ }^{*} \mathrm{~B} 4=\text { area } \mathrm{B} 4,{ }^{*} \mathrm{~B} 5=\text { area } \mathrm{B} 5,{ }^{*} \mathrm{C} 1=\text { area } \mathrm{C} 1,{ }^{*} \mathrm{C} 2=\text { area } \mathrm{C} 2,{ }^{*} \mathrm{C} 3=\text { area } \mathrm{C} 3, \\
{ }^{*} \mathrm{C} 4=\text { area } \mathrm{C} 4,{ }^{*} \mathrm{C} 5=\text { area } \mathrm{C} 5,{ }^{*} \mathrm{D} 1=\text { area } \mathrm{D} 1,{ }^{*} \mathrm{D} 2=\text { area } \mathrm{D} 2,{ }^{\circ} \mathrm{D} 3=\text { area } \mathrm{D} 3, \\
\left.{ }^{* D} 4=\text { area } \mathrm{D} 4,{ }^{*} \mathrm{D} 5=\text { area } \mathrm{D} 5\right)\end{array}$ \\
\hline G.B3-* & (auto name) & $\begin{array}{l}300 \text {-m overburden model }\left({ }^{*} \mathrm{~A} 1=\text { area } \mathrm{A} 1,{ }^{*} \mathrm{~A} 2=\text { area } \mathrm{A} 2,{ }^{*} \mathrm{~A} 3=\text { area } \mathrm{A} 3,\right. \\
{ }^{*} \mathrm{~B} 1=\text { area } \mathrm{B} 1,{ }^{*} \mathrm{~B} 2=\text { area } \mathrm{B} 2,{ }^{*} \mathrm{~B} 3=\text { area } \mathrm{B} 3,{ }^{*} \mathrm{~B} 4=\text { area } \mathrm{B} 4,{ }^{*} \mathrm{~B} 5=\text { area } \mathrm{B} 5, \\
{ }^{*} \mathrm{C} 1=\text { area } \mathrm{C} 1,{ }^{*} \mathrm{C} 2=\text { area } \mathrm{C} 2,{ }^{*} \mathrm{C} 3=\text { area } \mathrm{C} 3,{ }^{*} \mathrm{C} 4=\text { area } \mathrm{C} 4,{ }^{*} \mathrm{D} 1=\text { area } \mathrm{D} 1, \\
\left.{ }^{*} \mathrm{D} 2=\text { area } \mathrm{D} 2,{ }^{*} \mathrm{D} 3=\text { area } \mathrm{D} 3\right)\end{array}$ \\
\hline G.FLT_R2 & $\begin{array}{l}\text { nflt0l to } \\
\text { nflt } 30\end{array}$ & Fault model, revision 2 (from maps nfltol to nflt30) \\
\hline \multirow{4}{*}{ G.TSW1 } & TOP & Top surface of TSw1 unit \\
\hline & THICK & Thickness of part of TSw 1 unit above Repository Host Horizon \\
\hline & DIST_URB & Upper repository crown level distance to top TSw 1 (bottom PTn) \\
\hline & DIST_LRB & Lower repository expansion crown level distance to top TSw 1 (bottom PTn) \\
\hline \multirow{4}{*}{ G.RHH } & TOP & Top surface of Repository Host Horizon \\
\hline & TOP-5 & Top surface of Repository Host Horizon minus 5 meters \\
\hline & THICK & Total thickness of Repository Host Horizon \\
\hline & UP2TH & $\begin{array}{l}\text { Thickness of informal bottom part (Tptpull) of upper lithophysal zone } \\
\text { (Tptpul) that is below the top of the Reposotory Host Horizon (RHH) and } \\
\text { above the middle nonlithophysal zone (Tptpmn) }\end{array}$ \\
\hline \multirow{2}{*}{ G.RHHB } & DIST_URB & Upper repository crown level distance to top RHH \\
\hline & DIST_LRB & Lower repository expansion crown level distance to top $\mathrm{RHH}$ \\
\hline \multirow{2}{*}{ G.TPTPMN } & TOP & Top surface of middle nonlithophysal zone (Tptpmn) \\
\hline & THICK & Thickness of middle nonlithophysal zone (Tptpmn) \\
\hline \multirow{2}{*}{ G.TPTPLL } & TOP & Top surface of lower lithophysal zone (Tptpll) \\
\hline & THICK & Thickness of lower lithophysal zone (TptpII) \\
\hline G.TPTPLN & TOP & Top surface of lower nonlithophysal zone (Tptpln) \\
\hline
\end{tabular}




\begin{tabular}{|l|l|l|}
\hline & THICK & Thickness of lower nonlithophysal zone (Tptpln) \\
\cline { 2 - 3 } & TOP & Top surface of TSw3 unit \\
\cline { 2 - 3 } & TOP+10 & Top surface of TSw3 unit plus 10 meters \\
\cline { 2 - 3 } & THICK & Thickness of TSw3 unit \\
\hline \multirow{4}{*}{ G.TSW3B } & DIST_URB & Upper repository invert level distance to top of TSw3 \\
\cline { 2 - 3 } & DIST_LRB & Lower repository expansion invert level distance to top of TSw3 \\
\hline G.CHN & TOP & Top surface of CHn unit \\
\hline & TOP & Top of potentiometric surface \\
\cline { 2 - 3 } & UB_OFF & Upper repository invert level distance to top of groundwater table \\
\cline { 2 - 3 } & LB_OFF & $\begin{array}{l}\text { Lower repository expansion invert level distance to top of groundwater } \\
\text { table }\end{array}$ \\
\hline
\end{tabular}

\begin{tabular}{|c|c|c|}
\hline Volume Name & $\begin{array}{l}\text { Component } \\
\text { Name }\end{array}$ & Description \\
\hline \multicolumn{3}{|l|}{ Mining Models: } \\
\hline \multirow{4}{*}{ M.ESF_R4 } & N_PORTAL & North portal starter tunnel drill and blast section (Sta. $0+00$ to $0+60$ ) \\
\hline & ESF_NR & North ramp tunnel boring machine section (Sta. $0+60$ to $28+04.323$ ) \\
\hline & ESF MD & Main drift tunnel borning machine section (Sta. $28+04.323$ to $56+54.323$ ) \\
\hline & ESF SR & South ramp tunnel boring machine section (Sta. $56+54.323$ to $78+77.037$ ) \\
\hline
\end{tabular}




\section{Attachment VII \\ LIST OF FILES INCLUDED IN THE ARCHIVAL TAPE FOR THE DESIGN MODEL}

The following is a directory listing for the archive tape of the project YMP.MO3Q (Reference 5.7).

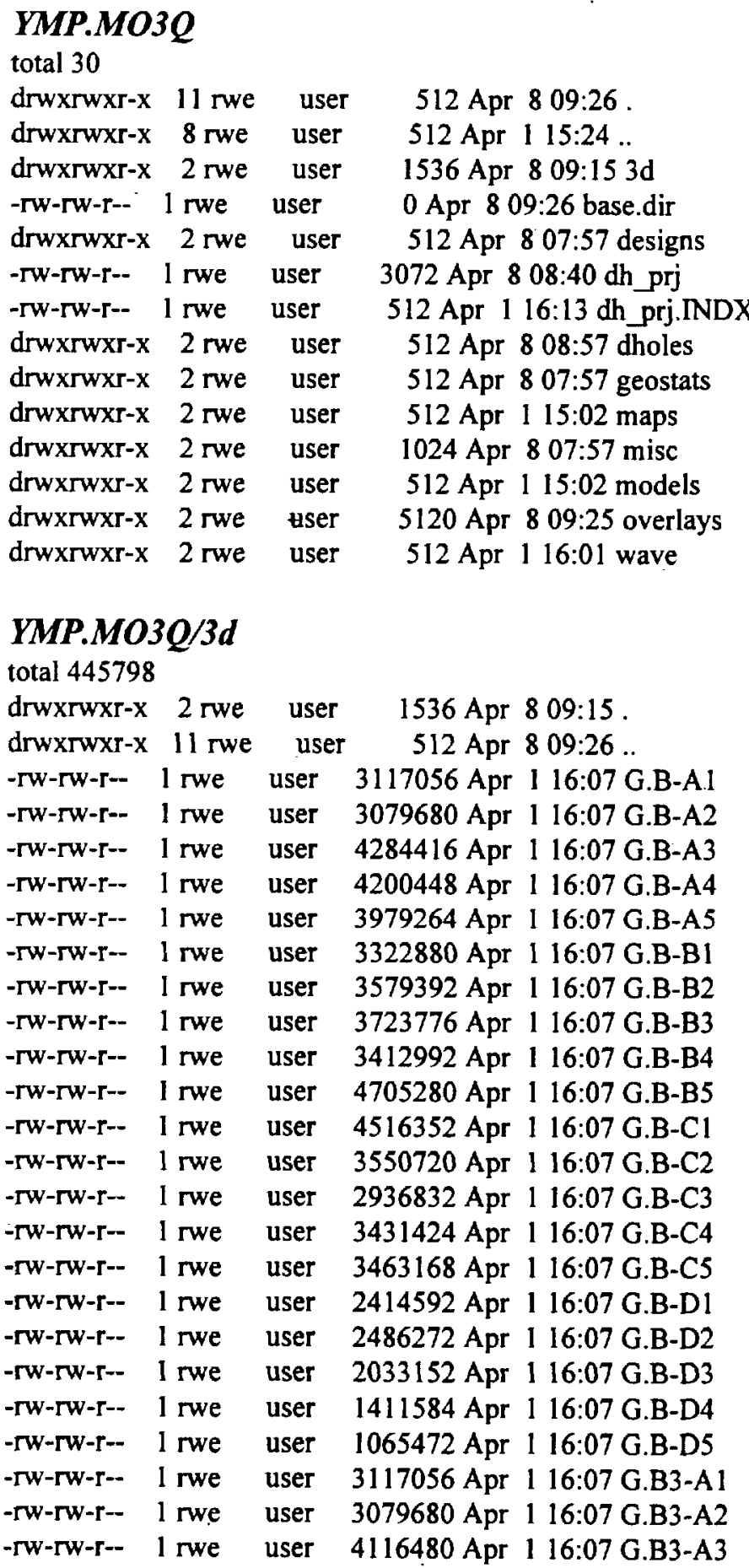




\begin{tabular}{|c|c|c|c|}
\hline$-\Gamma W-r W-r--$ & 1 rwe & user & 4669440 Apr 1 16:07 G.B3-B I \\
\hline -rW-rW-r-- & 1 rwe & user & 3579392 Apr 1 16:07 G.B3-B2 \\
\hline -rW-rW-I-- & 1 rwe & user & 3723776 Apr 1 16:08 G.B3-B3 \\
\hline$-\Gamma w-r w-r--$ & 1 rwe & user & 3412992 Apr 1 16:08 G.B3-B4 \\
\hline -rW-rW-r-- & 1 rwe & user & $4705280 \mathrm{Apr} 1 \mathrm{16}: 08 \mathrm{G} . \mathrm{B} 3-\mathrm{B} 5$ \\
\hline -rw-rw-r-- & I rwe & user & 4516352 Apr 1 16:08 G.B3-C1 \\
\hline$-\Gamma W-r W-r--$ & 1 rwe & user & 3550720 Apr $116: 08$ G.B3-C2 \\
\hline$-\Gamma W-\Gamma w-r--$ & 1 rwe & user & 2936832 Apr 1 16:08 G.B3-C3 \\
\hline -rw-rw-r-- & 1 rwe & user & 3431424 Apr 1 16:08 G.B3-C4 \\
\hline$-r w-r w-r--$ & 1 rwe & user & 2414592 Apr 1 16:08 G.B3-DI \\
\hline$-\Gamma W-r w-r--$ & 1 rwe & user & 2486272 Apr 1 16:08 G.B3-D2 \\
\hline -rw-rw-r-- & I rwe & user & 2033152 Apr 1 16:08 G.B3-D3 \\
\hline$-r W-r w-r--$ & 1 rwe & user & 1729536 Apr $116: 08$ G.CHN \\
\hline$-\Gamma w-r w-r--$ & 1 rwe & user & 2979840 Apr 1 16:08 G.FLT_R2 \\
\hline$-\Gamma W-r W-r--$ & 1 rwe & user & 1455104 Apr 1 16:08 G.GWL \\
\hline -rW-rW-r-- & 1 rwe & user & 7574528 Apr 1 16:08 G.RHH \\
\hline -rw-rw-r-- & 1 rwe & user & 3164160 Apr 8 09:15 G.RHHB \\
\hline$-r w-r w-r--$ & 1 rwe & user & 3117056 Apr $116: 0$ \\
\hline$-r w-r w-r--$ & 1 rwe & user & 3079680 Apr $116: 08$ G.T-A2 \\
\hline -rW-rW-r-- & 1 rwe & user & 2996736 Apr 116 \\
\hline$-\Gamma \mathrm{w}-\mathrm{rw}-\mathrm{r}-$ & 1 rwe & user & 4200448 Apr 1 16: \\
\hline$-r w-r w-r--$ & 1 rwe & user & 3979264 Apr $116: C$ \\
\hline$-r w-r w-r--$ & 1 rwe & user & 3322880 Apr $116:$ \\
\hline$-r w-r w-r--$ & 1 rwe & user & 3579392 Apr 1 16:08 G.T-B2 \\
\hline$-r w-r w-r--$ & 1 rwe & user & 3723776 Apr 1 16:08 G.T-B3 \\
\hline$-\Gamma W-\Gamma W-\Gamma-$ & 1 rwe & user & 3412992 Apr $116: 08$ G.T-B4 \\
\hline$-r w-r w-r--$ & 1 rwe & user & $4705280 \mathrm{Apr} 116: 09$ G.T-B5 \\
\hline$-r W-r w-r--$ & 1 rwe & user & 4516352 Apr $116: 09$ G.T-C1 \\
\hline$-\Gamma W-r w-r--$ & 1 rwe & user & 3550720 Apr $116: 09$ G.T-C2 \\
\hline$-\Gamma w-r w-r--$ & 1 rwe & user & 2936832 Apr I 16:09 G.T-C3 \\
\hline$-r w-r w-r--$ & 1 rwe & user & 3431424 Apr $116: 09$ G.T-C4 \\
\hline$-r w-r w-r--$ & I rwe & user & 3463168 Apr 1 16:09 G.T-C5 \\
\hline -rW-rw-r-- & 1 rwe & user & 2414592 Apr 1 16:09 G.T-DI \\
\hline$-r w-r w-r--$ & 1 rwe & user & 2486272 Apr 1 16:09 G.T-D2 \\
\hline -rw-rw-r-- & 1 rwe & user & 2033152 Apr 1 16:09 G.T-D3 \\
\hline$-r w-r w-r--$ & 1 rwe & user & 1411584 Apr 1 16:09 G.T-D4 \\
\hline$-\Gamma w-r w-r--$ & 1 rwe & user & 1065472 Apr 1 16:09 G.T-D5 \\
\hline$-\Gamma w-r w-r--$ & 1 rwe & user & 3827200 Apr $116: 09$ G.TPTPLL \\
\hline$-r w-r w-r--$ & 1 rwe & user & 4473856 Apr I 16:09 G.TPTPLN \\
\hline$-\Gamma \mathrm{W}-\mathrm{rW}-\mathrm{r}-$ & 1 rwe & user & 3659776 Apr 1 16:09 G.TPTPMN \\
\hline$-\Gamma \mathbf{w}-\mathbf{r w}-\mathbf{r - -}$ & 1 rwe & user & 6597120 Apr 8 08:03 G.TSW1 \\
\hline w-rw-r-- & 1 rwe & user & 7681024 Apr 1 16:09 G.TSW3 \\
\hline & & us & 2904576 Apr 8 09:15 G.TSW3B \\
\hline$\cdots$ & & user & 55296 Apr 1 16:25 M.ESF_R4 \\
\hline
\end{tabular}

YMP.MO3Q/designs

total 2

drwxrwxr-x 2 rwe user 512 Apr 8 07:57.

drwxrwxr-x 11 rwe user 512 Apr $809: 46$..

\section{YMP.MO3Q/dholes}

total 2495

drwxrwxr-x 2 rwe user 512 Apr 8 08:57. 


\begin{tabular}{|c|c|c|c|}
\hline drwxrwxr-x & 11 rwe & user & 512 Apr $809: 27$ \\
\hline$-\Gamma W-r W-\Gamma--$ & 1 rwe & user & 6656 Apr $808: 24 \mathrm{dh} 0$ \\
\hline$-r w-r w-r--$ & 1 rwe & user & 339 Apr $808: 24$ dh0.INDX \\
\hline$-\Gamma w-r w-r--$ & 1 rwe & user & 1024 Apr 1 16:12 dh 1 \\
\hline$-r w-r w-r--$ & 1 rwe & user & 339 Apr 1 16:12 dh1.INDX \\
\hline$-r W-r W-r--$ & 1 rwe & user & 1024 Apr $116: 12 \mathrm{dh} 2$ \\
\hline$-\Gamma W-r W-r--$ & 1 rwe & user & 339 Apr 1 16:12 dh2.INDX \\
\hline -rW-rW-r-- & 1 rwe & user & 1024 Apr 1 16:12 dh3 \\
\hline$-r w-r w-r--$ & 1 rwe & user & 339 Apr 1 16:12 dh3.INDX \\
\hline$-r W-r W-r--$ & 1 rwe & user & 703488 Apr 1 16:19 dh4 \\
\hline$-r w-r w-r--$ & 1 rwe & user & 178356 Apr 1 16:16 dh4.INDX \\
\hline$-\Gamma W-r W-r--$ & 1 rwe & user & 1024 Apr 1 16:12 dh5 \\
\hline$-r W-r W-r--$ & 1 rwe & user & 339 Apr 1 16:12 dh5.INDX \\
\hline$-\Gamma W-\Gamma W-r-i$ & 1 rwe & user & 1024 Apr 1 16:13 dh6 \\
\hline$-\Gamma W-r W-r--$ & 1 rwe & user & 339 Apr 1 16:13 dh6.INDX \\
\hline -rw-rw-r-- & 1 rwe & user & 266752 Apr $808: 25$ dh7 \\
\hline$-r w-r w-r--$ & 1 rwe & user & 18504 Apr 8 08:17 dh7.INDX \\
\hline$-\Gamma w-r w-r-$ & I rwe & user & 19968 Apr 8 08:40 dh8 \\
\hline $\mathbf{w}-\mathbf{r w}-$ & 1 rwe & user & 858 Apr 8 08:40 dh8.INDX \\
\hline W-rW-r-- & $1 \mathrm{rwe}$ & user & 64512 Apr 8 08:57 dh9 \\
\hline -rw-rw-r-- & 1 rwe & user & 8124 Apr 1 16:18 dh9.INDX \\
\hline
\end{tabular}

\section{YMP.MO3Q/geostats}

total 2

drwxrwxr-x 2 rwe ùser

drwxrwxr-x 11 rwe user

512 Apr 8 07:57.

512 Apr 8 09:46..

\section{YMP.MO3Q/maps}

total 2

drwxrwxr-x 2 rwe user

drwxrwxr-x 11 rwe user

512 Apr 1 15:02.

512 Apr 8 09:46..

\section{YMP.MO3Q/misc}

total 52588

\begin{tabular}{|c|c|c|c|c|}
\hline $\begin{array}{l}\text { WXrwXr-X } \\
\text { wXrwxr-X }\end{array}$ & $\begin{array}{l}2 \text { rwe } \\
11 \text { rwe }\end{array}$ & $\begin{array}{l}\text { use } \\
\text { use }\end{array}$ & $\begin{array}{r}1024 \mathrm{Apr} \\
512 \mathrm{Apr}\end{array}$ & $\begin{array}{l}807: 57 \\
809: 27\end{array}$ \\
\hline w-r-ir- & 1 rwe & user & $3650290 \mathrm{~A}$ & 18 day faults \\
\hline $\begin{array}{l}N X I-\mathrm{XI}-\mathrm{X} \\
\mathrm{NXI}-\mathrm{XI}-\mathrm{X}\end{array}$ & $\begin{array}{l}1 \text { rwe } \\
1 \text { rwe }\end{array}$ & $\begin{array}{l}\text { user } \\
\text { user }\end{array}$ & & \\
\hline vXr-Xr-X & $1 \mathrm{rwe}$ & user & 1457 & \\
\hline$N-\mathrm{T}-\mathrm{-T}--$ & 1 rwe & user & 3183212 & 00.dxf \\
\hline v-r--r-- & 1 rwe & user & 332022 & so_201.dxf \\
\hline V-T--r-- & 1 rwe & user & 8010790 Oct & pso_20 \\
\hline V-T--T-- & I rwe & user & 87428120 & pso 20 \\
\hline
\end{tabular}

\section{YMP.MO3Q/models}

total 2

drwxrwxr-x 2 rwe user

drwxrwxr-x 11 rwe user

512 Apr 1 15:02.

512 Apr 8 09:47..

\section{YMP.MO3Q/overlays}

total 24503

drwxrwxr-x 2 rwe user 5120 Apr 8 09:25. 


\begin{tabular}{|c|c|c|c|}
\hline drwxrwxr-x & 11 rwe & user & 512 Apr $809: 27$.. \\
\hline -rw-rw-r-- & 1 rwe & user & 99328 Apr 1 16:32 B-A 1 \\
\hline$-r W-r W-r--$ & 1 rwe & user & 94464 Apr 1 16:32 B-A2 \\
\hline -rW-rWW-r-- & 1 rwe & user & 86528 Apr 1 16:32 B-A3 \\
\hline$-r w-r w-r--$ & 1 rwe & user & 85760 Apr 1 16:32 B-A4 \\
\hline$-\Gamma W-r W-r--$ & 1 rwe & user & 89088 Apr 1 16:32 B-A5 \\
\hline$-r w-r w-r--$ & 1 rwe & user & 88320 Apr 1 16:32 B-B 1 \\
\hline$-\Gamma W-r w-r--$ & 1 rwe & user & $114432 \mathrm{Apr} 116: 32 \mathrm{~B}-\mathrm{B} 2$ \\
\hline -rw-rW-r-- & I rwe & user & 99840 Apr 1 16:32 B-B3 \\
\hline -rW-rW-r-- & 1 rwe & user & 93696 Apr 1 16:32 B-B4 \\
\hline$-r w-r w-r--$ & 1 rwe & user & 120064 Apr 1 16:32 B-B5 \\
\hline$-\Gamma W-r W-r-=$ & 1 rwe & user & $129792 \mathrm{Apr} 116: 32 \mathrm{~B}-\mathrm{Cl}$ \\
\hline -rw-rw-r-- & I nwe & user & $115200 \mathrm{Apr} 116: 32 \mathrm{~B}-\mathrm{C} 2$ \\
\hline -rw-rw-r-- & I rwe & user & 80896 Apr I 16:32 B-C3 \\
\hline$-\Gamma W-r w-r--$ & 1 rwe & user & 89088 Apr 1 16:32 B-C4 \\
\hline$-\Gamma W-r W-r--$ & 1 rwe & user & 84480 Apr 1 16:32 B-C5 \\
\hline$-r w-r w-r--$ & 1 rwe & user & $63488 \mathrm{Apr} 1 \mathrm{16}: 32 \mathrm{~B}-\mathrm{D} 1$ \\
\hline$-r w-r w-r--$ & 1 rwe & user & 68352 Apr 1 16:32 B-D2 \\
\hline$-\Gamma W-r W-\Gamma--$ & 1 rwe & user & 55552 Apr $116: 32$ B-D3 \\
\hline$-r w-r w-r--$ & 1 rwe & user & 40704 Apr 1 16:32 B-D4 \\
\hline -rw-rw-r-- & 1 rwe & user & 31232 Apr 1 16:32 B-D5 \\
\hline$-r w-r w-r--$ & 1 we & user & $107008 \mathrm{Apr} 1$ 16:32 B3-A1 \\
\hline$-\Gamma W-r W-\Gamma--$ & 1 rwe & user & 102144 Apr 1 16:32 B3-A2 \\
\hline -rw-rw-r-- & 1 rwe & user & 79104 Apr 1 16:32 B3-A3 \\
\hline$-\Gamma W-\Gamma W-T--$ & 1 rwe & user & 96000 Apr 1 \\
\hline$-\Gamma W-\Gamma W-\Gamma--$ & 1 rwe & user & 122880 Apr $116: 32$ B3-B2 \\
\hline$-r w-r w-r--$ & I rwe & user & 107776 Apr 1 16:32 B3-B3 \\
\hline$-\Gamma W-r W-\Gamma--$ & I rwe & user & $101376 \mathrm{Apr}$ \\
\hline$-\Gamma w-r w-r--$ & 1 rwe & user & $128000 \mathrm{Apr}$ \\
\hline$-\Gamma W-r w-r--$ & 1 rwe & user & $138496 \mathrm{Apr} 1$ 16:32 B3-C1 \\
\hline -rW-rw-r-- & 1 rwe & user & $123136 \mathrm{Apr}$ \\
\hline$-r w-r w-r--$ & 1 rwe & user & 88832 Apr 1 16:32 B3-C3 \\
\hline$-r w-r w-r--$ & 1 rwe & user & 97024 Apr 11 \\
\hline -rw-rw-r-- & 1 rwe & user & 71680 Apr $116: 32$ B3-D1 \\
\hline$-r w-r w-r--$ & I rwe & user & 76288 Apr 1 16:32 B3-D2 \\
\hline$-r w-r w-r-$ & 1 rwe & user & 63744 Apr 1 16:32 B3-D3 \\
\hline$-\Gamma w-r W-r--$ & 1 rwe & user & 19712 Apr $116: 34$ CHnb \\
\hline$-r w-r w-r--$ & 1 rwe & user & 48896 Apr $116: 34 \mathrm{CHnc}$ \\
\hline$-r w-r w-r--$ & 1 rwe & user & $26368 \mathrm{Apr} 116: 34 \mathrm{CHnf}$ \\
\hline$-\Gamma W-\Gamma W-T--$ & 1 rwe & user & 23808 Apr $116: 34$ CHnp \\
\hline$-r w-r w-r--$ & 1 rwe & user & 1023232 Apr 1 16:35 DAYf0996 \\
\hline -rw-rw-r-- & 1 rwe & user & 20992 Apr 8 09:13 GWLBoff \\
\hline -rw-rw-r-- & 1 rwe & user & 27648 Apr 8 09:13 GWL_RIB \\
\hline$-r w-r w-r--$ & 1 rwe & user & 17664 Apr 8 09:13 GWL_RIBp \\
\hline$-r w-r w-r--$ & 1 rwe & user & 22016 Apr 8 09:13 GWUBoff \\
\hline -rw-rw-r-- & 1 rwe & user & 14848 Apr $116: 36$ R+762_L \\
\hline$-r w-r w-r--$ & 1 rwe & user & 17664 Apr 1 16:36 R+762_Um \\
\hline$-r w-r w-r--$ & 1 rwe & user & 18432 Apr 8 09:12 RHH_DLRB \\
\hline -rw-rw-r-- & 1 rwe & user & 21248 Apr 8 09:12 RHH_DURB \\
\hline -rW-rw-r-- & 1 rwe & user & 24576 Apr 1 16:34 RHHb \\
\hline$-\Gamma W-\Gamma W-\Gamma--$ & 1 rwe & user & 66560 Apr $116: 34$ RHHc \\
\hline -rw-rw-r-- & 1 rwe & user & 65024 Apr 1 16:34 RHHf \\
\hline$-r w-r--$ & 1 rwe & user & 22784 Apr I 16:34 RHHic \\
\hline -rw-rw-r-- & 1 rwe & user & 24576 Apr 1 16:34 RHHip \\
\hline
\end{tabular}




\begin{tabular}{|c|c|c|c|}
\hline -rW-rw-r-- & 1 rwe & user & 19456 Apr $116: 34$ RHHo \\
\hline$-\Gamma W-r W-r--$ & 1 rwe & user & 19968 Apr 1 16:34 RHHp \\
\hline$-r w-r w-r--$ & l rwe & user & 14848 Apr 2 07:38 Rinv_L \\
\hline -rw-rw-r-- & I rwe & user & 17664 Apr 2 07:38 Rinv_Um \\
\hline$-\Gamma W-\Gamma W-\Gamma--$ & l rwe & user & 297472 Apr 1 16:32 T5-Al \\
\hline -rW-rW-r-- & 1 rwe & user & 295168 Apr 1 16:32 T5-A2 \\
\hline$-\Gamma W-r w-r--$ & I rwe & user & 205824 Apr 1 16:32 T5-A3 \\
\hline$-\Gamma W-r W-r--$ & I rwe & user & 243712 Apr 1 16:32 T5-A4 \\
\hline -rw-rw-r-- & I rwe & user & 264448 Apr 1 16:32 T5-A5 \\
\hline -rw-rw-r-- & 1 rwe & user & 413184 Apr 1 16:32 T5-B1 \\
\hline -rW-rw-r-- & I rwe & user & 432384 Apr 1 16:32 T5-B2 \\
\hline$-r W-r W-r--$ & 1 rwe & user & 357632 Apr 1 16:32 T5-B3 \\
\hline$-\Gamma W-\Gamma W-r--$ & l rwe & user & 382976 Apr 1 16:32 T5-B4 \\
\hline$-r W-r W-r--$ & 1 rwe & user & 484864 Apr 1 16:32 T5-B5 \\
\hline -rW-rW-r-- & I rwe & user & 511744 Apr $116: 32$ T5-C1 \\
\hline$-r w-r w-r--$ & 1 rwe & user & 431872 Apr 1 16:32 T5-C2 \\
\hline$-\Gamma W-r W-r--$ & 1 rwe & user & 371456 Apr 1 16:32 T5-C3 \\
\hline -rW-rW-r-- & 1 rwe & user & 335872 Apr 1 16:32 T5-C4 \\
\hline -rW-rw-r-- & l rwe & user & 261632 Apr 1 16:32 T5-C5 \\
\hline$-\Gamma W-\Gamma W-\Gamma--$ & I rwe & user & 183296 Apr 1 16:32 T5-D1 \\
\hline -rW-rW-r-- & 1 rwe & user & 207104 Apr 1 16:32 T5-D2 \\
\hline$-r w-r w-r--$ & 1 rwe & user & 189440 Apr I 16:32 T5-D3 \\
\hline$-r w-r w-r--$ & 1 rwe & user & 120064 Apr 1 16:32 T5-D4 \\
\hline -rW-rW-r-- & 1 rwe & user & 44800 Apr 1 16:32 T5-D5 \\
\hline -rw-rw-r-- & 1 rwe & user & 18944 Apr 8 09:12 TSw IDLRB \\
\hline$-r w-r w-r--$ & 1 rwe & user & 20480 Apr 8 09:12 TSw1DURB \\
\hline$-r w-r w-r--$ & 1 rwe & user & 24320 Apr 1 16:33 TSw1b \\
\hline -rw-rw-r-- & I rwe & user & 49408 Apr 1 16:33 TSwlc \\
\hline$-r w-r w-r--$ & 1 rwe & user & 112896 Apr $116: 33$ TSwlf \\
\hline$-\Gamma W-\Gamma W-r--$ & 1 rwe & user & 29440 Apr 1 16:33 TSwlic \\
\hline -rw-rw-r-- & 1 rwe & user & 25088 Apr 1 16:33 TSwlip \\
\hline -rw-rw-r-- & I rwe & user & 55808 Apr 1 16:33 TSwlo \\
\hline$-r w-r w-r--$ & 1 rwe & user & 22528 Apr $116: 33$ TSwlp \\
\hline -rw-rw-r-- & 1 rwe & user & 17408 Apr 8 09:12 TSw3DLRB \\
\hline -rw-rw-r-- & 1 rwe & user & 22016 Apr 8 09:12 TSw3DURB \\
\hline -rw-rw-r-- & 1 rwe & user & 20992 Apr 1 16:34 TSw3b \\
\hline -rW-rW-r-- & l rwe & user & 52224 Apr $116: 34$ TSw3c \\
\hline -rW-rw-r-- & 1 rwe & user & 26368 Apr 1 16:34 TSw3f \\
\hline -rw-rw-r-- & I rwe & user & 19712 Apr 1 16:34 TSw3ic \\
\hline -rW-rw-r-- & l rwe & user & 23808 Apr 1 16:34 TSw3ip \\
\hline -rW-rW-r-- & l rwe & user & 23808 Apr 1 16:34 TSw3p \\
\hline$-r W-r w-r--$ & 1 rwe & user & 22528 Apr 1 16:34 Tptpllb \\
\hline -rW-rW-r-- & l rwe & user & 48384 Apr 1 16:34 Tptpllc \\
\hline$-r w-r w-r--$ & 1 rwe & user & 27904 Apr 1 16:34 Tptpllf \\
\hline$-\Gamma W-r W-\Gamma--$ & 1 rwe & user & 33536 Apr 1 16:34 Tptpllic \\
\hline -rw-rw-r-- & 1 rwe & user & 23808 Apr 1 16:34 Tptpllip \\
\hline -rw-rw-r-- & 1 rwe & user & 16640 Apr 1 16:34 Tptpllo \\
\hline -rw-rw-r-- & 1 rwe & user & 24832 Apr 1 16:34 Tptpllp \\
\hline -TW-rW-r-- & 1 rwe & user & 20736 Apr 1 16:34 Tptplnb \\
\hline -rw-rw-r-- & 1 rwe & user & 54016 Apr $116: 34$ Tptplnc \\
\hline -rW-rW-r-- & I rwe & user & 24832 Apr 1 16:34 Tptplnf \\
\hline -rw-rw-r-- & 1 rwe & user & 27136 Apr 1 16:34 Tptplnic \\
\hline$-r W-r W-r-$ & 1 rwe & user & 23552 Apr $116: 34$ Tptplnip \\
\hline -rw-rw-r-- & I rwe & user & 23552 Apr 1 16:34 Tptplnp \\
\hline
\end{tabular}




\begin{tabular}{|c|c|c|c|}
\hline$-r W-r W-r--$ & l rwe & user & 61952 Apr 1 16:34 Tptpmnb \\
\hline -rw-rw-r-- & 1 rwe & user & 49920 Apr $116: 34$ Tptpmnc \\
\hline -rw-rw-r-- & 1 rwe & user & 26880 Apr I 16:34 Tptpmnf \\
\hline$-\Gamma W-r W-r--$ & I rwe & user & 25088 Apr 1 16:34 Tptpmnic \\
\hline -ГW-rW-T-- & 1 rwe & user & 24320 Apr 1 16:34 Tptpmnip \\
\hline$-\Gamma W-r W-r--$ & 1 rwe & user & 24576 Apr 1 16:34 Tptpmno \\
\hline$-\Gamma W-r W-\Gamma--$ & 1 rwe & user & 36352 Apr 1 16:34 Tptpmnp \\
\hline -rw-rw-r-- & 1 rwe & user & 18432 Apr $116: 35$ nflt01m \\
\hline -rw-rw-r-- & 1 rwe & user & 16896 Apr $116: 35$ nflt02m \\
\hline$-\Gamma W-r W-\Gamma--$ & 1 rwe & user & 18432 Apr $116: 35$ nflt03m \\
\hline$-r w-r w-r--$ & 1 rwe & user & 15872 Apr $116: 35$ nflt04m \\
\hline -rw-rw-r-- & I rwe & user & 15360 Apr $116: 35$ nflt05m \\
\hline$-r w-r w-r--$ & l rwe & user & 15360 Apr $116: 35$ nflt06m \\
\hline$-\Gamma W-\Gamma W-r--$ & 1 rwe & user & 18944 Apr $116: 35$ nflt07m \\
\hline -rW-rw-r-- & I rwe & user & 15872 Apr $116: 35$ nflt08m \\
\hline$-\Gamma W-\Gamma W-\Gamma--$ & 1 rwe & user & 15872 Apr $116: 35$ nflt09m \\
\hline$-\Gamma w-r w-r--$ & 1 rwe & user & 15104 Apr $116: 35$ nflt10m \\
\hline -rw-rw-r-r & 1 rwe & user & 18176 Apr $116: 35$ nflt $1 / \mathrm{m}$ \\
\hline -rw-rw-r-- & I rwe & user & 16128 Apr $116: 35$ nflt $12 \mathrm{~m}$ \\
\hline$-\Gamma W-r W-r--$ & l rwe & user & 17152 Apr $116: 35$ nflt $13 \mathrm{~m}$ \\
\hline$-\Gamma W-\Gamma W-\Gamma--$ & 1 rwe & user & 15616 Apr $116: 35$ nflt $14 m$ \\
\hline -rW-rW-r-- & 1 rwe & user & 15104 Apr $116: 35$ nflt $15 \mathrm{~m}$ \\
\hline -rw-rw-r-- & I rwe & user & 15616 Apr $116: 35 \mathrm{nflt} 16 \mathrm{~m}$ \\
\hline$-\Gamma W-r W-r--$ & 1 rwe & user & 16128 Apr $116: 35$ nflt $17 \mathrm{~m}$ \\
\hline -rW-rW-r-- & 1 rwe & user & 16128 Apr $116: 35$ nflt $18 m$ \\
\hline$-r w-r w-r--$ & 1 rwe & user & 16128 Apr $116: 35$ nflt $19 m$ \\
\hline$-\Gamma W-r W-r--$ & 1 rwe & user & 16640 Apr $116: 35$ nflt20m \\
\hline -rw-rw-r-- & 1 rwe & user & 16640 Apr $116: 35$ nflt $21 \mathrm{~m}$ \\
\hline -rW-rW-r-- & 1 rwe & user & $15360 \mathrm{Apr} 1 \mathrm{16:35} \mathrm{nflt} 22 \mathrm{~m}$ \\
\hline -rw-rw-r-- & I rwe & user & $15360 \mathrm{Apr} 1 \mathrm{l} 6: 35 \mathrm{nflt} 23 \mathrm{~m}$ \\
\hline$-r w-r w-r=-$ & 1 rwe & user & 15360 Apr $116: 35$ nflt $24 m$ \\
\hline -rw-rw-r-- & I rwe & user & 15360 Apr $116: 35$ nflt $25 \mathrm{~m}$ \\
\hline$-r w-r w-r--$ & 1 rwe & user & 17920 Apr $116: 35$ nflt $26 \mathrm{~m}$ \\
\hline -rw-rw-r-- & 1 rwe & user & 16896 Apr $116: 35$ nflt $27 \mathrm{~m}$ \\
\hline -rW-rW-r-- & I rwe & user & 15872 Арг $116: 35 \mathrm{nflt} 28 \mathrm{~m}$ \\
\hline$-\Gamma W-r W-r--$ & l rwe & user & $16384 \mathrm{Apr} 116: 35 \mathrm{nflt} 29 \mathrm{~m}$ \\
\hline -rW-rW-r-- & l rwe & user & 15104 Apr $116: 35$ nflt $30 \mathrm{~m}$ \\
\hline
\end{tabular}

\section{YMP.MO3Q/wave}

total 2

drwxrwxr-x 2 rwe user 512 Apr 116:01. drwxrwxr-x 11 rwe user 512 Apr $809: 47$.. 


\section{Attachment VIII \\ SOURCE CODE LISTING FOR UNIX SHELL SCRIPTS USED IN THE DESIGN MODEL}

Listed below are the source code for the UNIX shell scripts used in this design analysis. How they were used in the design analysis are described in Section 6.2. These script files are contained in the archive tape (Reference 5.7) and are in the directory $/ Y M P . M O 3 Q / m i s c$ (Attachment VII).

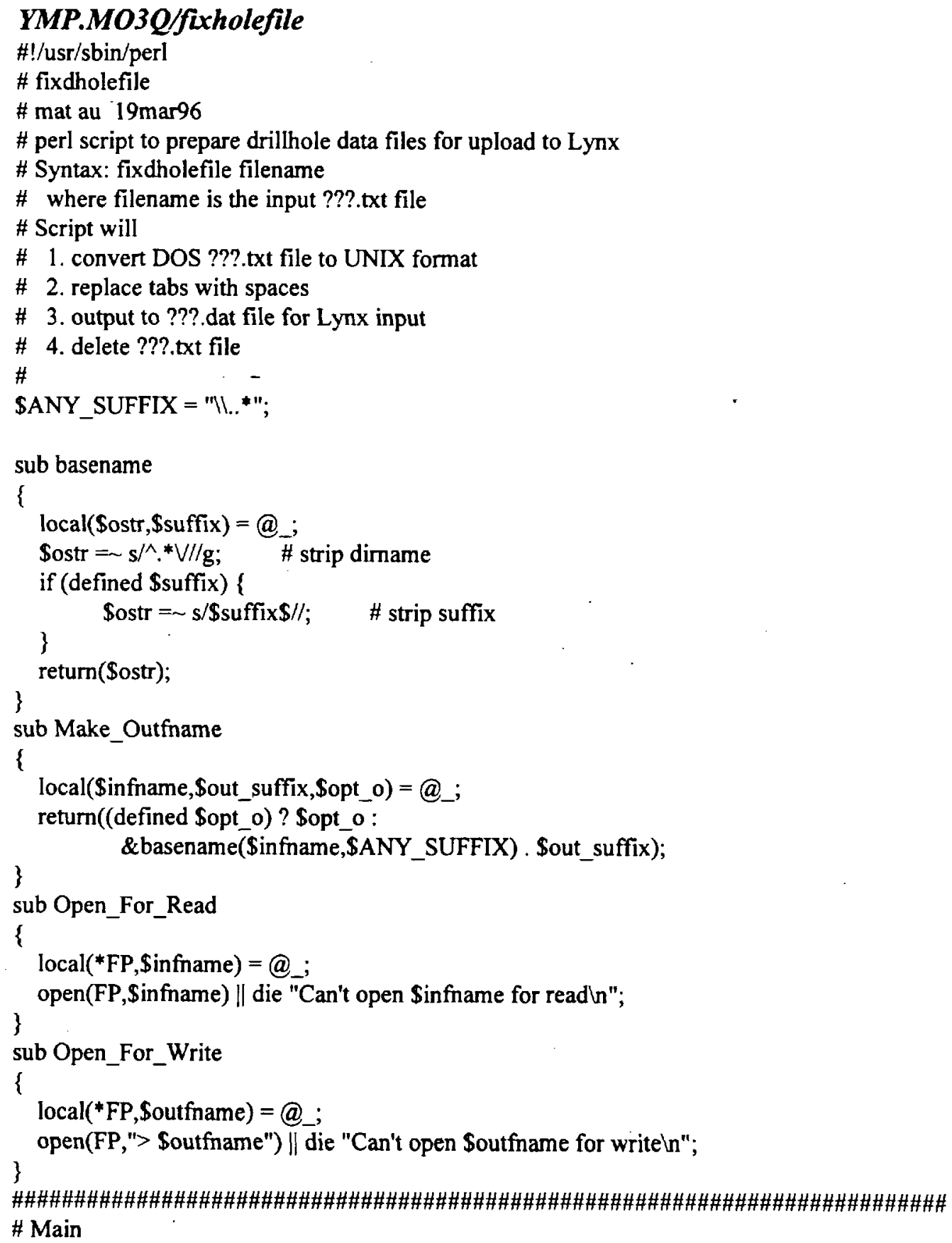


\{ \# start of MAIN program

if $(\$ 1=$ "ENTITIES") \{ \# Loop to locate ENTITIES section

while (\$1 != "ENDSEC") \{ \# check for end of ENTITIES (ENDSEC)

if $(\$ 1==$ "LINE") \{ \# start of LINE entity getline

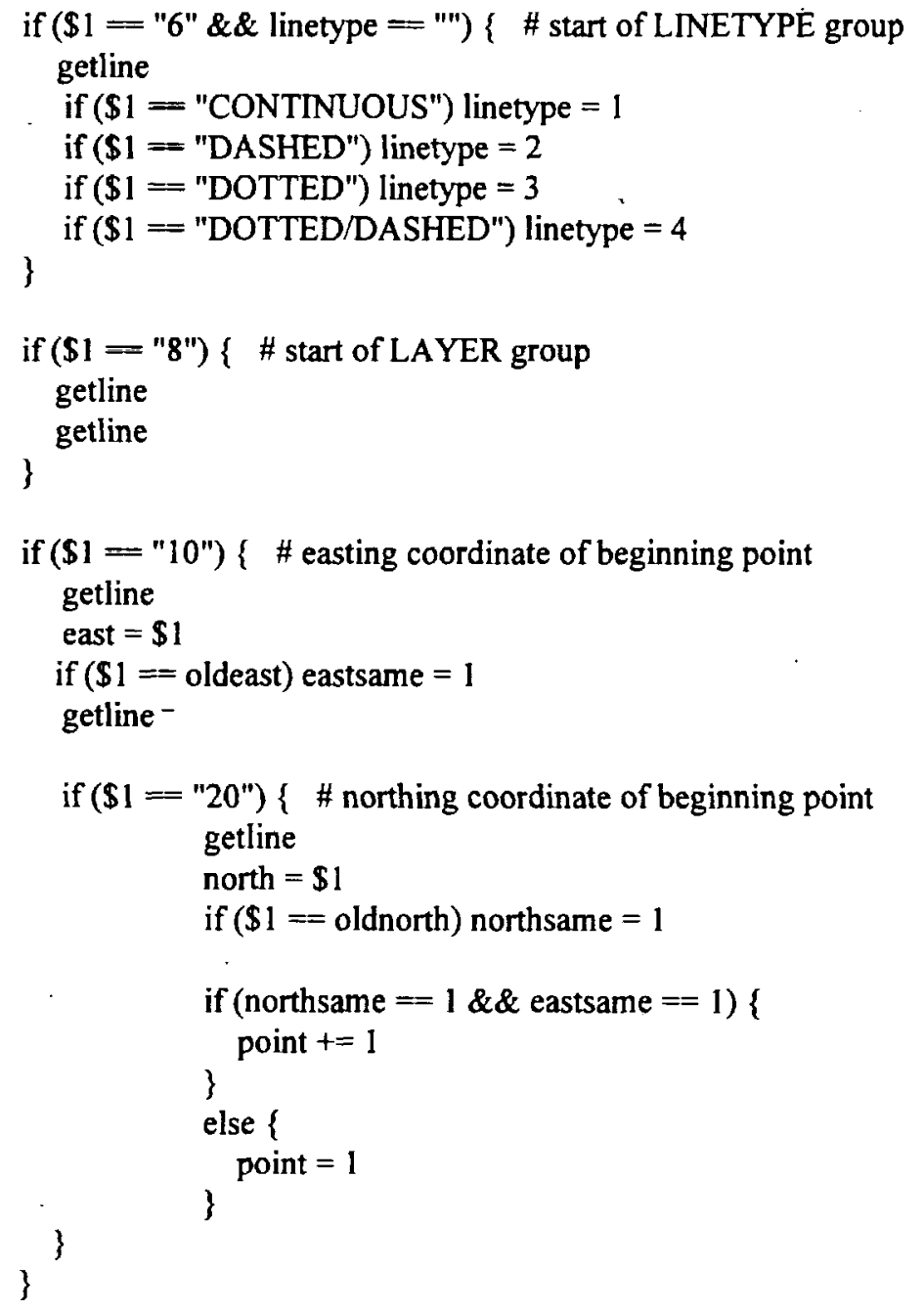




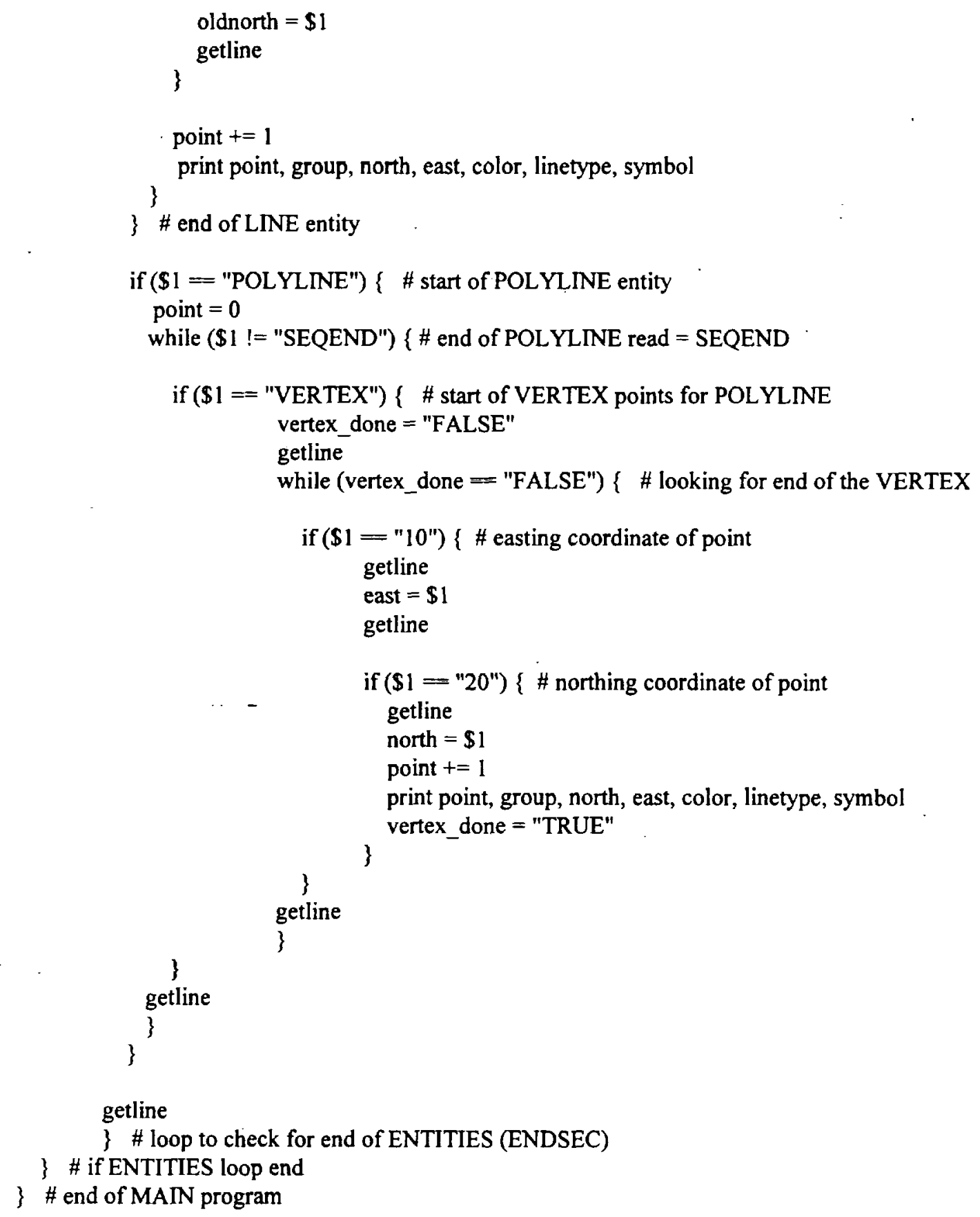

\section{YMP.MO3Q/e2m-map.awk}

\#\#\#\#\#\#\#\#\#\#\#\#\#\#\#\#\#\#\#\#\#\#\#\#\#\#\#\#\#\#\#\#\#\#\#\#\#\#\#\#\#\#\#\#\#\#\#\#\#\#\#\#\#\#\#\#\#\#\#\#\#\#\#\#\#\#\#\#\#\#\#\#\# \#\#\#\# e2m-map.awk

\#\#\#\# Awk script to translate a Lynx map (overlay) file from English units

\#\#\# to metric.

\#\#\#\#

\#\#\# SYNTAX:

\#\#\#\# awk -f e2m-map.awk inputfile > outputfile \#\#\# 


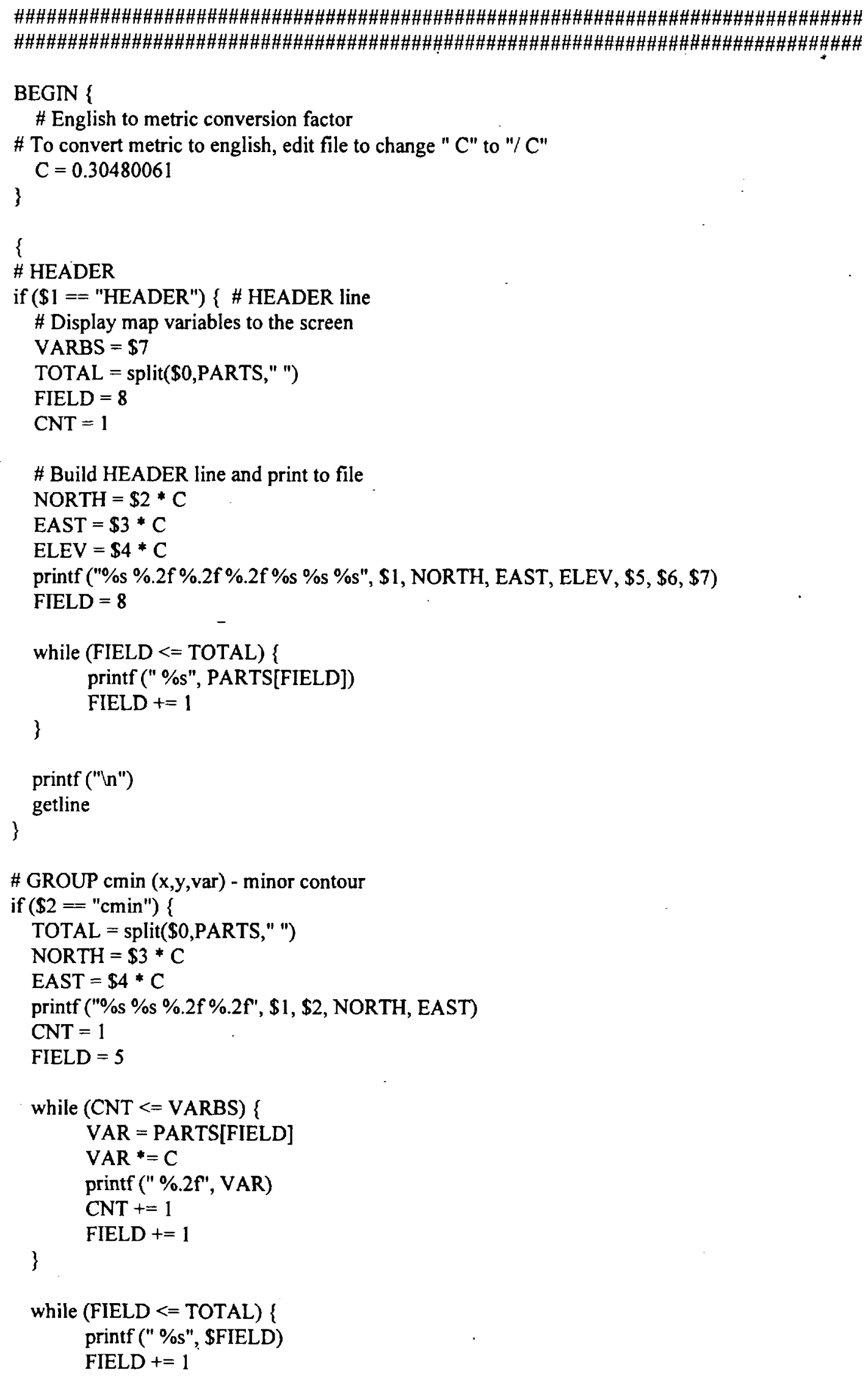




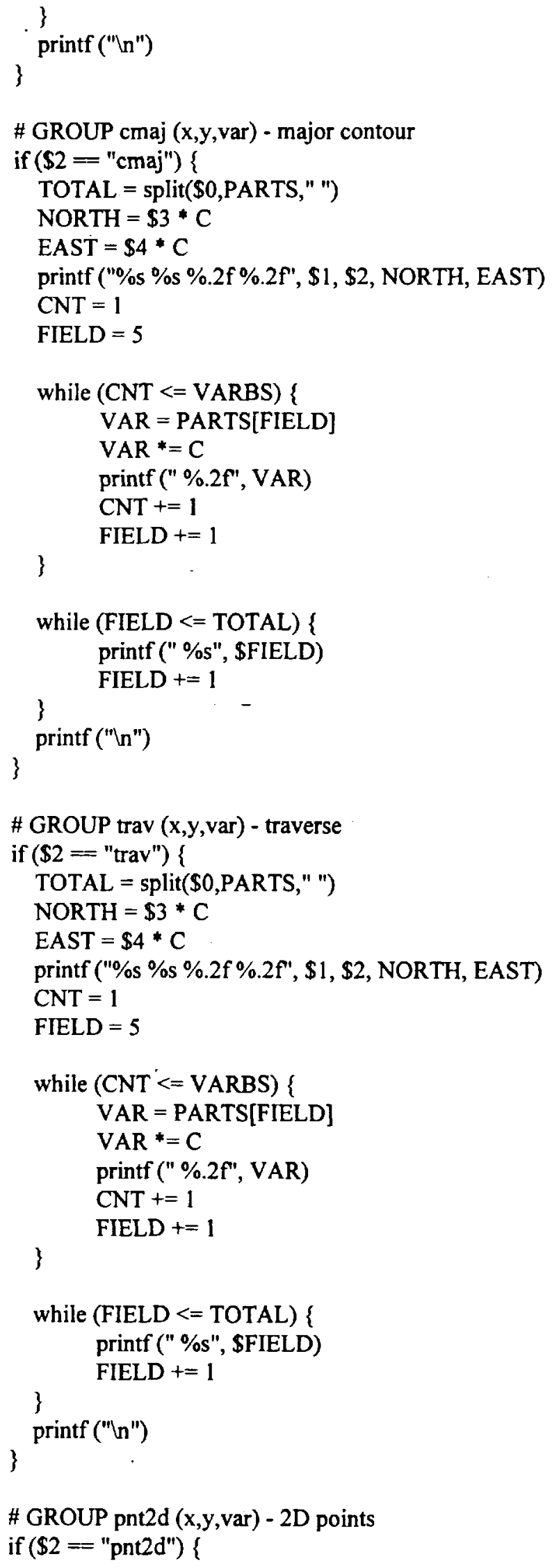




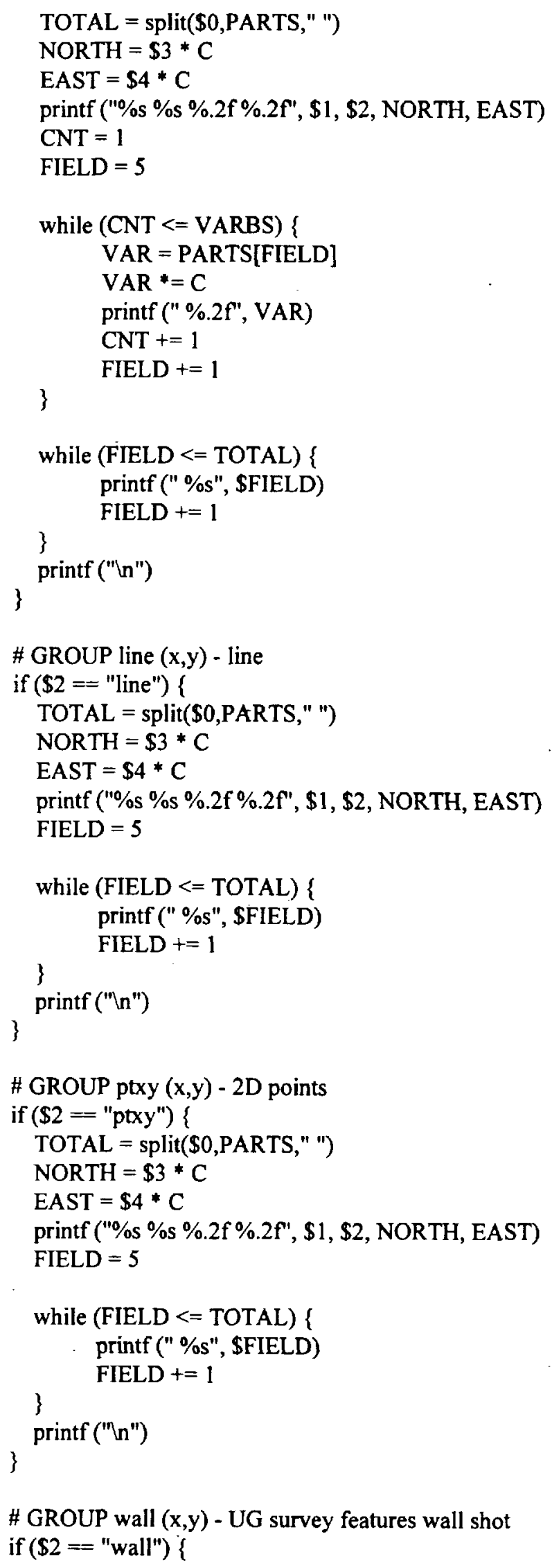




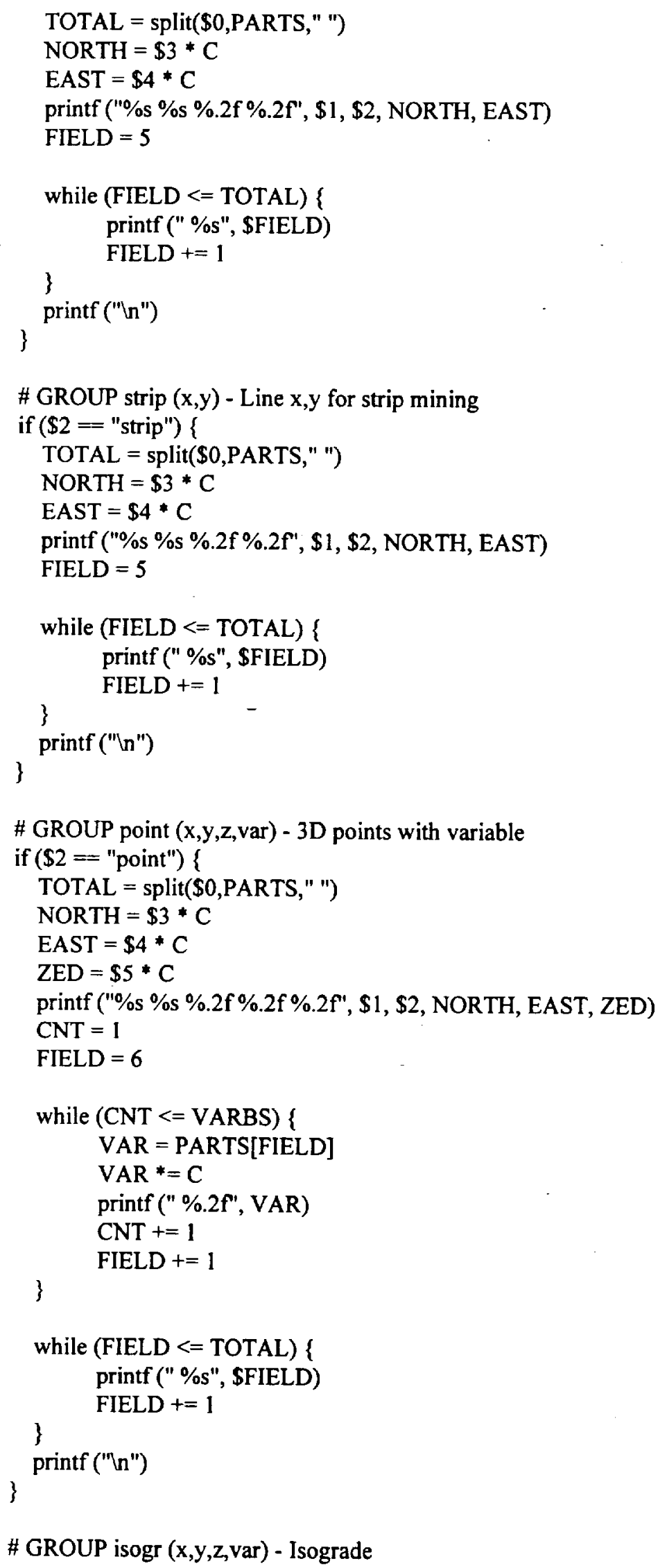




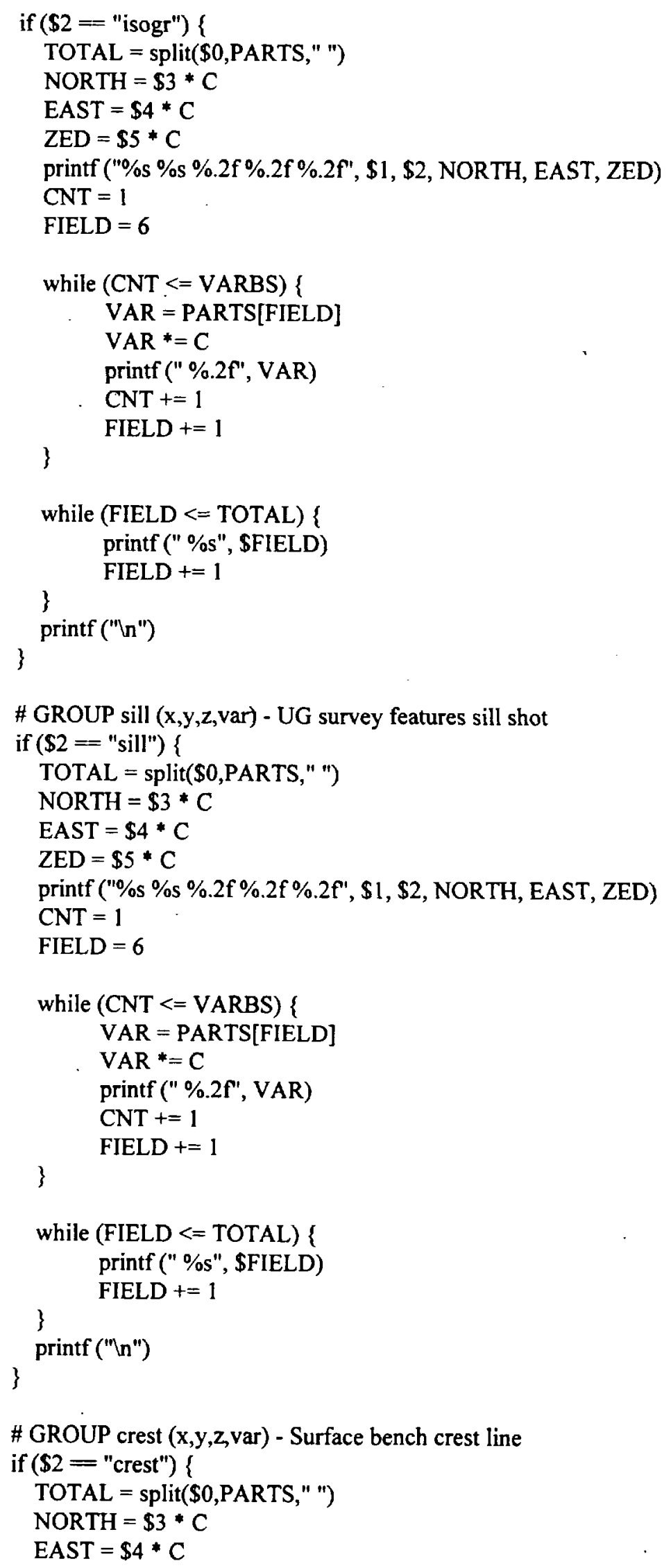




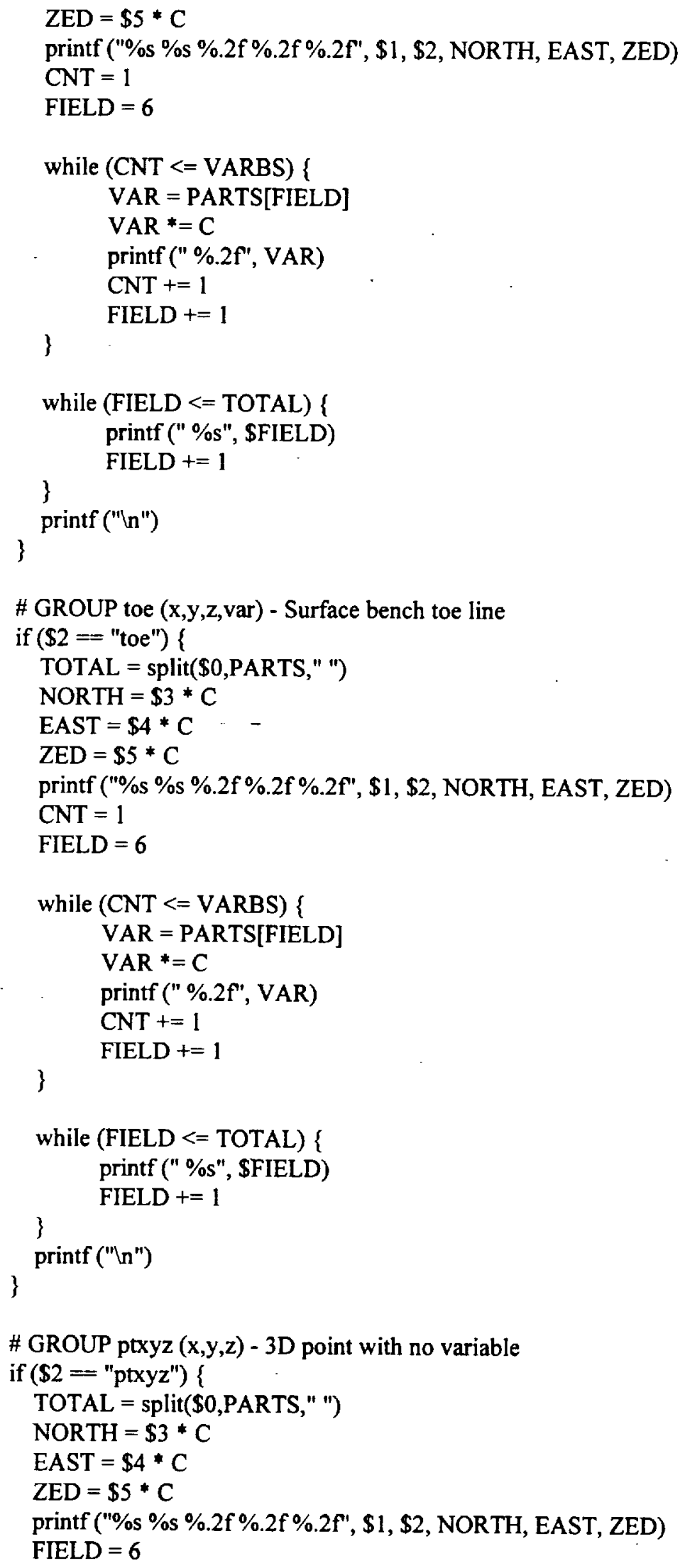




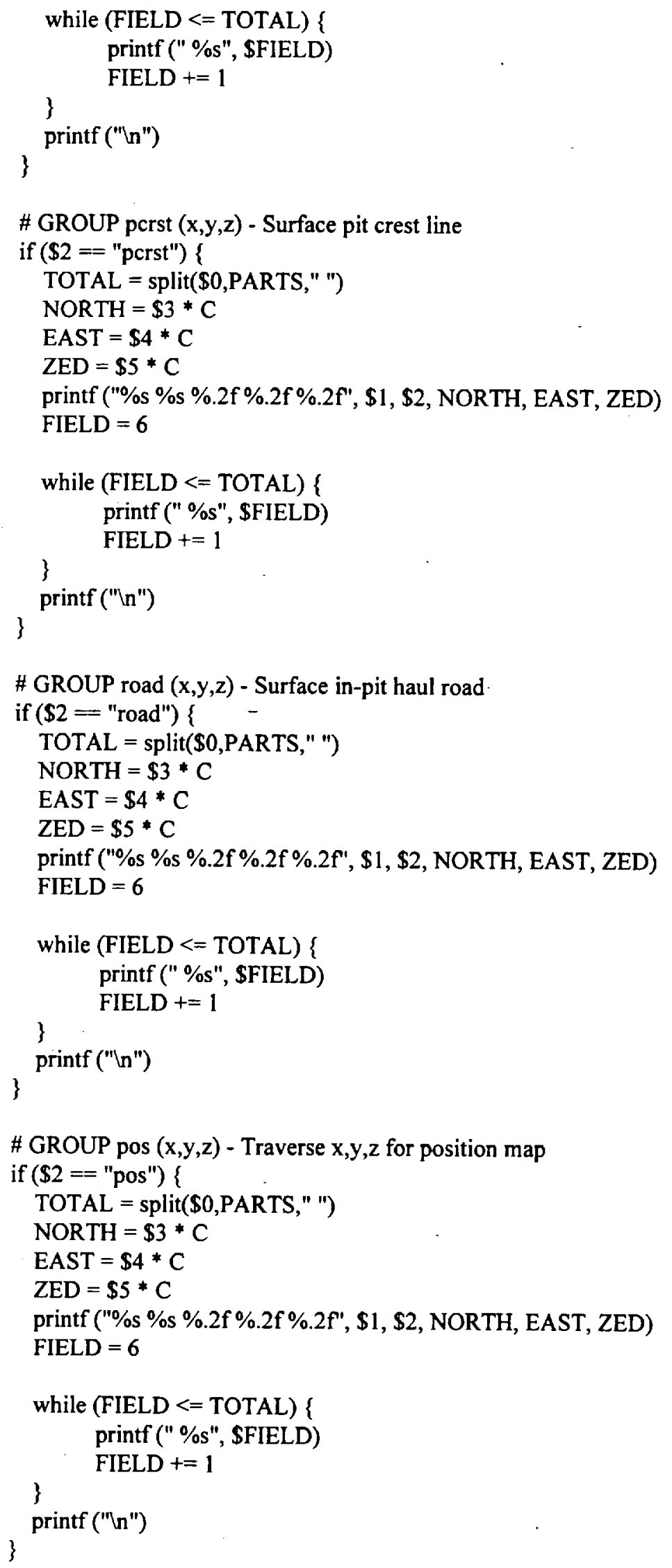




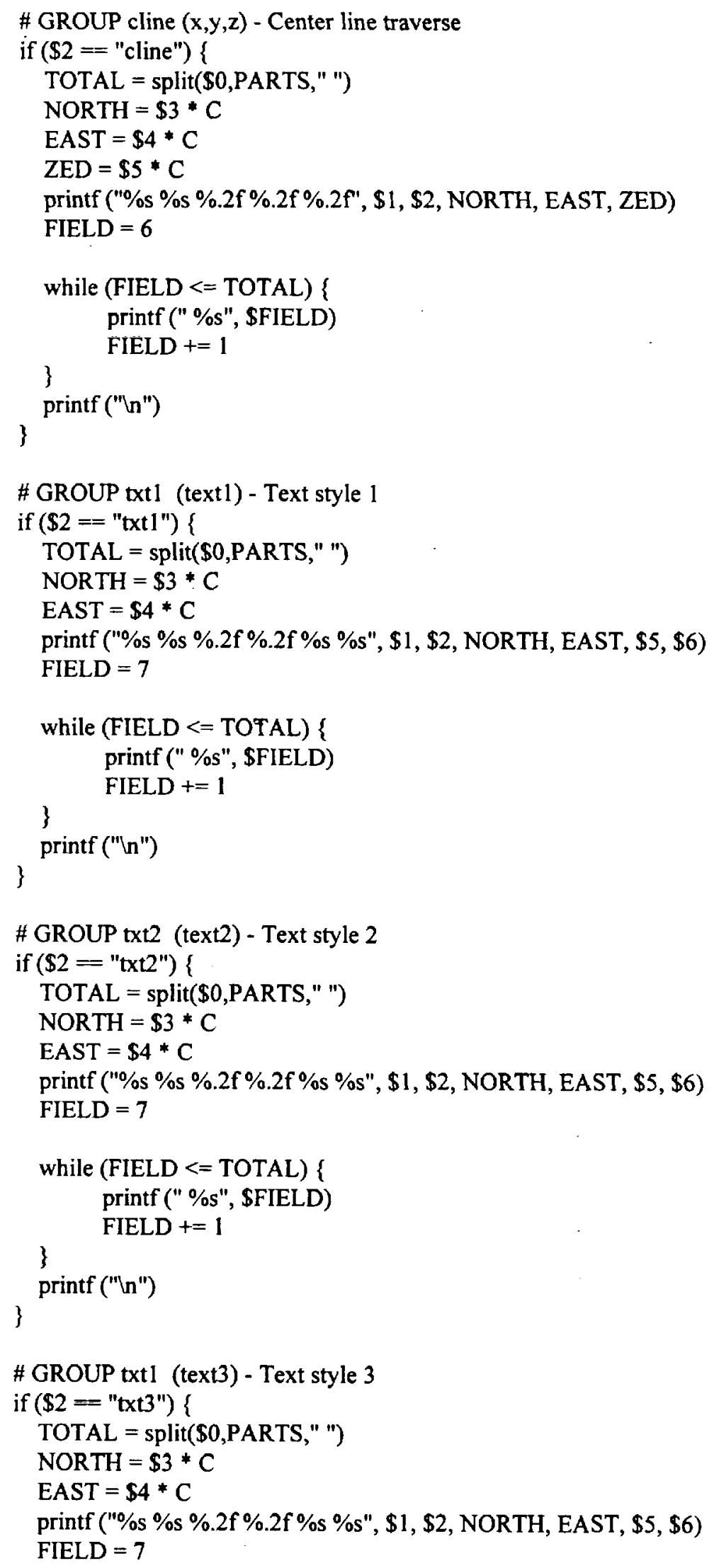




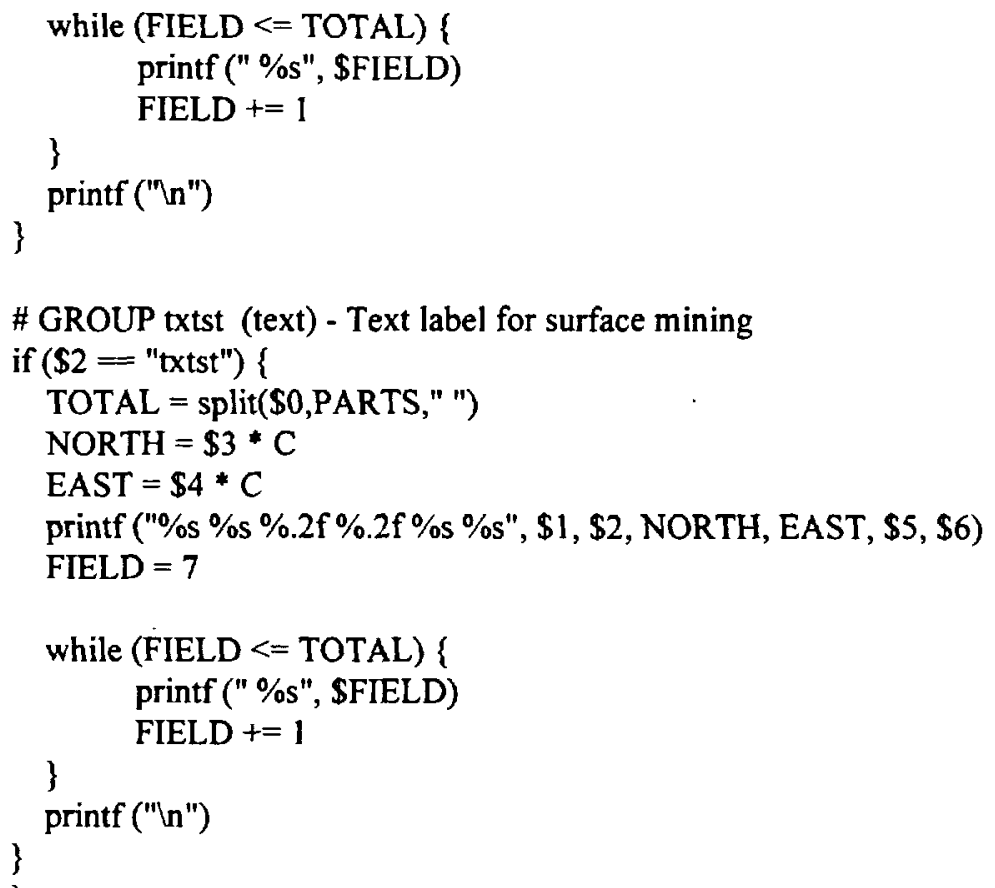

